
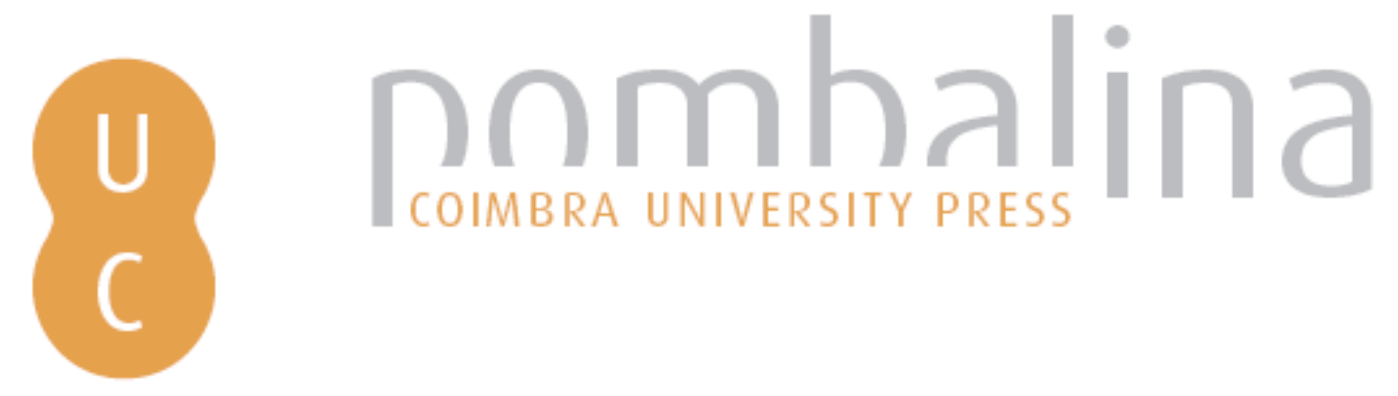

\title{
Espaços e paisagens: antiguidade clássica e heranças contemporâneas: Vol.2 Línguas e Literaturas: Idade Média, Renascimento, Recepção
}

\begin{tabular}{|c|c|}
\hline Autor(es): & $\begin{array}{l}\text { Congresso da Associação Portuguesa de Estudos Clássicos, 7, Évora, } \\
2008\end{array}$ \\
\hline Publicado por: & $\begin{array}{l}\text { Associação Portuguesa de Estudos Clássicos; Centro de Estudos } \\
\text { Clássicos e Humanísticos; Imprensa da Universidade de Coimbra }\end{array}$ \\
\hline $\begin{array}{l}\text { URL } \\
\text { persistente: }\end{array}$ & URI:http://hdl.handle.net/10316.2/2343 \\
\hline DOI: & DOI:http://dx.doi.org/10.14195/978-972-98142-2-8 \\
\hline Accessed : & 26-Apr-2023 12:02:11 \\
\hline
\end{tabular}

A navegação consulta e descarregamento dos títulos inseridos nas Bibliotecas Digitais UC Digitalis, UC Pombalina e UC Impactum, pressupõem a aceitação plena e sem reservas dos Termos e Condições de Uso destas Bibliotecas Digitais, disponíveis em https://digitalis.uc.pt/pt-pt/termos.

Conforme exposto nos referidos Termos e Condições de Uso, o descarregamento de títulos de acesso restrito requer uma licença válida de autorização devendo o utilizador aceder ao(s) documento(s) a partir de um endereço de IP da instituição detentora da supramencionada licença.

Ao utilizador é apenas permitido o descarregamento para uso pessoal, pelo que o emprego do(s) título(s) descarregado(s) para outro fim, designadamente comercial, carece de autorização do respetivo autor ou editor da obra.

Na medida em que todas as obras da UC Digitalis se encontram protegidas pelo Código do Direito de Autor e Direitos Conexos e demais legislação aplicável, toda a cópia, parcial ou total, deste documento, nos casos em que é legalmente admitida, deverá conter ou fazer-se acompanhar por este aviso.

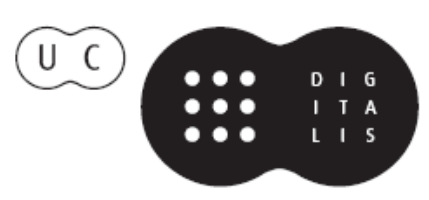




\section{Espaços e Paisagens}

Antiguidade Clássica e Heranças

Vol. II

Francisco Oliveira, Cláudia Teixeira e Paula Barata Dias

IMPRENSA DA UNIVERSIDADE DE COIMBRA 


\section{HVMANITAS SVPPLEMENTVM • ESTUDOS MONOGRÁFICOS}

ISSN: $2182-8814$

Apresentação: esta série destina-se a publicar estudos de fundo sobre um leque variado de temas e perspetivas de abordagem (literatura, cultura, história antiga, arqueologia, história da arte, filosofia, língua e linguística), mantendo embora como denominador comum os Estudos Clássicos e sua projeção na Idade Média, Renascimento e receção na actualidade. 
(Página deixada propositadamente em branco) 
(Página deixada propositadamente em branco) 


\section{Espaços e Paisagens}

Antiguidade Clássica e Heranças Contemporâneas

VII Congresso da Associação Portuguesa de Estudos Clássicos

Évora, 10-12 de Abril de 2008

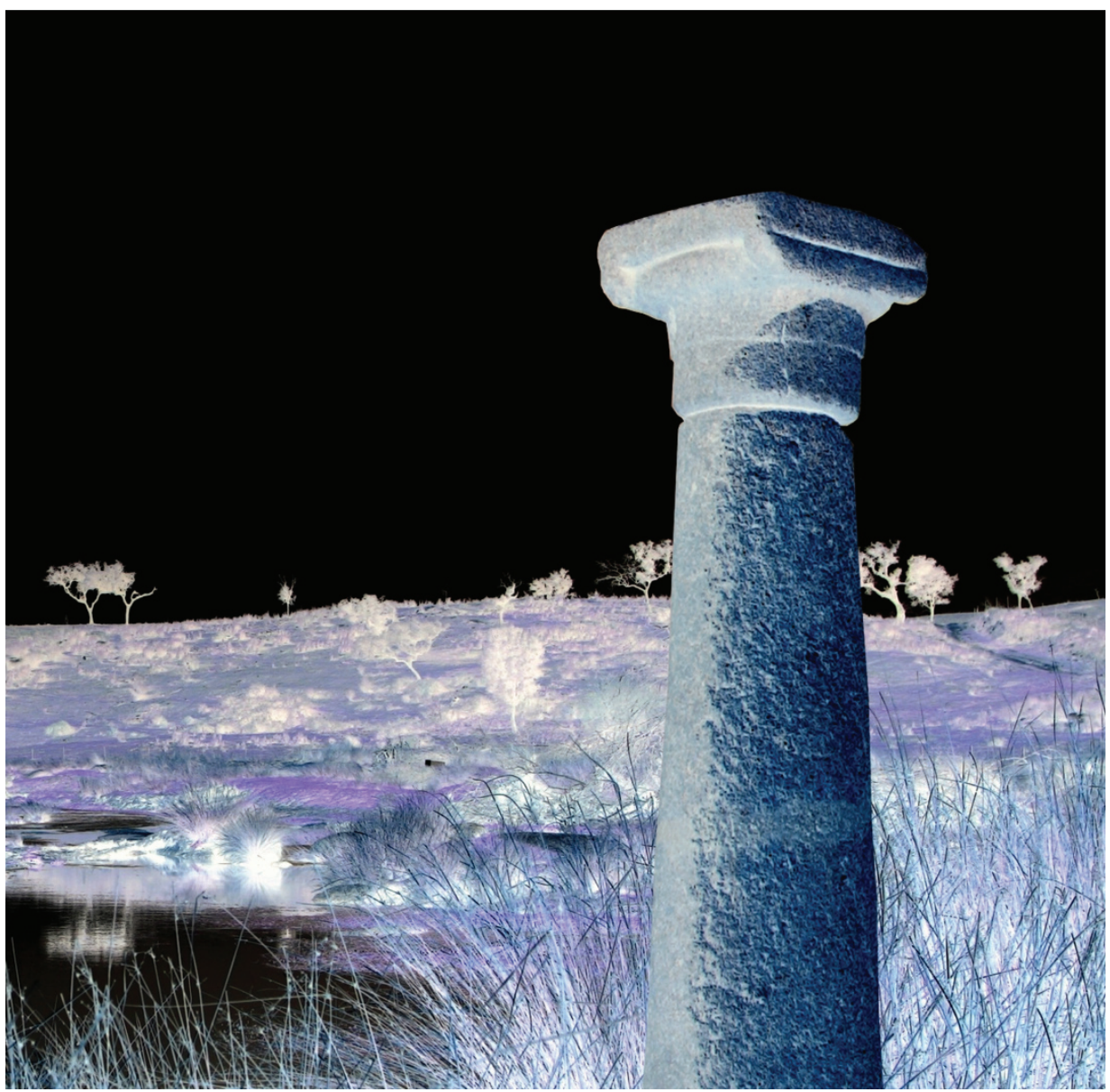


(Página deixada propositadamente em branco) 


\section{Espaços e Paisagens}

Antiguidade Clássica e Heranças Contemporâneas

Vol. II Línguas e Literaturas. Idade Média. Renascimento. Recepção

Francisco de Oliveira, Cláudia Teixeira, Paula Barata Dias (Coords.)

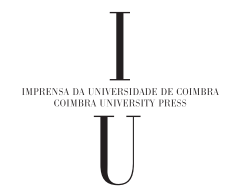


Todos os VOlumes Desta SÉRIE SÃo SUJEITOS A ARBITRAGEM CIENTÍfICA INDEPENDENTE.

Título • Espaços e Paisagens. Antiguidade Clássica e Heranças Contemporâneas Vol. II. Línguas e Literaturas. Idade Média. Renascimento. Recepção

Coordenação • Francisco de Oliveira, Cláudia Teixeira, Paula Barata Dias

\section{Série Hvmanitas Svpplementvm}

Coordenador Científico do plano de ediçâo: Maria do Céu Fialho

Conselho Editorial

José Ribeiro Ferreira

Francisco de Oliveira

Maria de Fátima Silva

Nair Castro Soares

Director Técnico: Delfim Leăo

Obra realizada no Âmbito das actividades da UI\&D

Centro de Estudos Clássicos e Humanísticos

\section{EDIÇÃo}

Imprensa da Universidade de Coimbra

URL: http://www.uc.pt/imprensa_uc

E-mail: imprensa@uc.pt

Vendas online:

http://www.livrariadaimprensa.com

\section{CoORdENAÇÃo EDITORIAL}

Imprensa da Universidade de Coimbra

Concepção gráfica \& Paginação

Rodolfo Lopes

Pré-IMPRESSÃo

Imprensa da Universidade de Coimbra

\author{
Impressáo e ACABAmento \\ www.artipol.net \\ ISBN \\ 978-989-26-0283-7 \\ ISBN DigITAL \\ 978-989-26-0294-3 \\ DOI \\ http://dx.doi.org/10.14195/978-972-98142-2-8 \\ Depósito Legal \\ $346983 / 12$ \\ 1ª EDIÇÁO: $\mathrm{CECH} / \mathrm{APEC} \cdot 2009$ \\ 2a EdiçĂO: IUC • 2012
}

\footnotetext{
(C) JULHO 2012.

IMPRENSA DA UNIVERSIDADE DE COIMBRA

Classica Digitalia Vniversitatis Conimbrigensis (http://classicadigitalia.uc.pt)

Centro de Estudos Clássicos e Humanísticos da Universidade de Coimbra
}

Reservados todos os direitos. Nos termos legais fica expressamente proibida a reprodução total ou parcial por qualquer meio, em papel ou em edição electrónica, sem autorização expressa dos titulares dos direitos. É desde já excepcionada a utilização em circuitos académicos fechados para apoio a leccionação ou extensấo cultural por via de e-learning. 


\section{Nota de Apresentação}

A Associação Portuguesa de Estudos Clássicos - APEC optou há alguns anos pela deslocalização do seu congresso periódico, o qual, de Coimbra, já peregrinou por Viseu, Aveiro, Faro, Braga, Lisboa e Évora.

Foi exactamente nesta belíssima cidade que se realizou o VII Congresso Internacional da APEC, nos dias 10-12 de Abril de 2008.

Nesse encontro, uma enorme plêiade de participantes desenvolveu um exercício de intensa interdisciplinaridade à volta do tema Espaços e paisagens. Antiguidade Clássica e heranças contemporâneas. Foi de cerca de uma centena o número de conferencistas presentes, um terço dos quais vindos de países estrangeiros, e é para eles que vai um primeiro agradecimento, em especial para os que aceitaram o desafio da publicação das suas comunicações.

O segundo agradecimento é dirigido às entidades que assumiram a coresponsabilidade da organização e da edição:

- o Centro de Estudos Clássicos e Humanísticos da Universidade de Coimbra, coordenado pela Professora Doutora Maria do Céu Zambujo Fialho;

- o Centro de História da Arte e de Investigação Artística da Universidade de Évora, dirigido pela Prof. Doutora Christine Zurbach;

- o Centro Interdisciplinar de História, Culturas e Sociedades da Universidade de Évora, coordenado pela Prof. Doutora Mafalda Soares da Cunha;

— o Laboratório de Arqueologia "Pinho Monteiro" da Universidade de Évora, presidido pelo Prof. Doutor Jorge de Oliveira;

- o Departamento de Linguística e Literaturas da Universidade de Évora. 
Os agradecimentos que endereçamos a estas entidades são extensivos às próprias instituições acolhedoras, a Universidade de Coimbra e a Universidade de Évora, e, nesta cidade, também ao Governo Civil de Évora, à Câmara Municipal de Évora, ao Comando da Unidade de Apoio e ao Banco Millenium BCP, cujos responsáveis mobilizaram toda a sua clarividência e generosidade para garantir as melhores condições para a realização deste evento cultural e científico.

Em terceiro lugar, manifestamos a nossa viva gratidão às entidades financiadoras, com particular relevo para o sempre solícito apoio da FCT - Fundação para a Ciência e Tecnologia, da Fundação Calouste Gulbenkian e da Fundação Engenheiro António de Almeida.

Mas seria injusto não valorizar também a colaboração da Dra Carla Braz, tanto no secretariado do congresso como na recolha do material, dos senhores Dr. Rodolfo Lopes e Luís Miguel Barata Dias, na preparação da edição digital, e do Doutor Delfim Leão, pelo interesse em promover a divulgação através de Classica Digitalia.

Estamos certos de que tais apoios, colaborações, financiamentos, patrocínios e responsáveis se sentirão compensados pela qualidade dos escritos dados ao prelo, organizados em três volumes com o título geral Espaços e Paisagens. Antiguidade Clássica e Heranças Contemporâneas e os subtítulos correspondentes:

\section{- vol. 1 Linguas e Literaturas. Grécia e Roma \\ - vol. 2 Linguas e Literaturas. Idade Média. Renascimento. Recepção \\ - vol. 3 História e Arqueologia}

No seu conjunto, tais contributos, incluindo os de jovens investigadores, ilustram uma grande diversidade de perspectivas, uma enorme riqueza e variedade de temas, da filologia grega e latina e da tradição clássica à literatura comparada, da arte e do urbanismo à arqueologia e à economia, da política à filosofia, e desde a Antiguidade até aos nossos dias.

Por acréscimo, ficam assim também nobilitados os estudos clássicos, humanísticos, históricos, filosóficos e literários em Portugal, com a Associação Portuguesa de Estudos Clássicos - APEC a cumprir a missão cultural e científica consagrada nos seus estatutos, em especial no espaço da lusofonia e da União Europeia. 
Comissão Científica

Ana Cardoso de Matos

Arnaldo Espírito Santo

Cláudia Teixeira

Cristina Pimentel

Filipe Themudo Barata

Francisco de Oliveira

Hermínia Vilar

Jorge de Oliveira

José Alberto Gomes Machado

Leonor Rocha

Manuel Patrocínio

Mafalda Soares da Cunha

Maria de Fátima Sousa e Silva

Maria do Céu Fialho

Ricardo Santos

Teresa Santos
Comissão Organizadora

André Carneiro

Armando Martins

Carla Braz (secretariado)

Clara Oliveira

Cláudia Teixeira

Francisco de Oliveira

Jorge de Oliveira

Leonor Rocha

Manuel Patrocínio

Paula Barata Dias

Ricardo Santos

Valentina Castro

Coordenação do Volume

Francisco de Oliveira

Cláudia Teixeira

Paula Barata Dias 
(Página deixada propositadamente em branco) 


\section{ÍNDICE}

VoL. 1 LínguAS E LiteratuRAs. GRÉCLA E RoMA

\section{I - Antiguidade Grega}

Espaços do Grego e espaços do outro nas Suplicantes de Ésquilo

Carlos A. Martins de Jesus

Paisagens marinhas no Hipólito de Eurípides

Maria do Céu Fialho

Tebas: a cidade de Dioniso. O caso de Héracles de Eurípides

Sofia Frade

Nas moradas das ninfas: o cenário do drama satírico

Tereza Virgínia Ribeiro Barbosa

A ágora de Atenas. Coração de uma urbe cosmopolita

Maria de Fátima Silva

O espaço rural ateniense no teatro aristofânico

Márcia Cristina Lacerda Ribeiro

Espaços concebidos pela mente

Susana Marques Pereira

Quando Pã e as Ninfas convertiam os simples mortais

Turismo e património na Antiguidade Clássica: o texto atribuído a Fílon de Bizâncio sobre as Sete Maravilhas 


\section{II - Antiguidade Romana}

El espacio de la mujer en la medicina romana

José Pablo Barragán Nieto

Espacios para la curación: la domus en la tradición hipocrático-galénica

Ma Carmen Fernández Tijero

Espacios literarios para la botánica: un jardín de plantas medicinales

A configuração do espaço poético: concepções sobre Metricologia Latina

Entre vida pública e luxuria privada. A propósito das villae de Luculo Manuel Tröster

A Sicília e a Cilícia na vida de Cícero

Virgínia Soares Pereira

Píndaro e Horácio face a face

Maria Mafalda de Oliveira Viana

Virgílio e a invenção da paisagem simbólica

Luís M. G. Cerqueira

Um repasto na Arcádia: as Bucólicas de Virgílio

Inês de Ornellas e Castro

A poetização do espaço nas Bucólicas de Virgílio: simbologia da vida humana, entre a euforia e a disforia

António Moniz

Mitos de fundação de cidades e a representação do espaço urbano nas Metamorphoses de Ovídio

Manuel Rolph de Viveiros Cabeceiras

O mundo natural e o espaço do humano na poesia trágica de Séneca:

Troades e Thyestes

Mariana Horta e Costa Matias 
Os espaços das Troades de Séneca

Salomão parodiado: elementos judaicos na paisagem pompeiana

O Anfiteatro de César: a única obra que a Fama há-de celebrar Joana Mestre Costa

De rio lamacento a corrente cristalina: a transformação do espaço e da paisagem em Silvas 4.3

Ana Maria dos Santos Lóio

Paisaje físico y paisaje humano de la Germania según César y Tácito Aurora López

A ekphrasis suetoniana da Domus Aurea

Villae y otros espacios de recreo en las Vidas de los Doce Césares de Suetonio Må. J. PÉreZ IbáñeZ

Roma nas Vidas Paralelas de Plutarco

JoAquim Pinheiro

O espaço britânico e a paisagem no Agricola de Tácito 


\section{III - Antiguidade Tardia e Idade Média}

Interpelações entre espaço e paisagem: uma leitura das Confissões

de Agostinho

Teresa Santos

Espaço e fronteiras do mundo romano na Antiguidade Tardia.

Continuidade e rupturas em relação à Europa Actual

Paula Barata Dias

El paisaje en la Peregrinatio Egeriae

Ana Isabel Martín Ferreira

\section{IV - Humanismo}

Espaço e alegoria na poesia épica portuguesa seiscentista

Espaço literário feminino. A obra de Maria de Mesquita Pimentel

Paisaje, clima y carácter en De bumana physiognomonia de

Giovan Battista della Porta

Miguel Ángel GonzÁlez Manjarrés

Espaços para o dever e o lazer num modelo de educação humanística (1599)

Margarida Miranda

Utopía, espacios soñados y Mito Clásico en la Tragicomedia de Los Jardines

y Los Campos Sabeos de Feliciana Enríquez de Guzmán

Cristina de la Rosa Cubo 
Paisagem do cárcere. $\mathrm{O}$ topos literário numa epopeia neolatina

As minas de ouro das Américas, novos espaços para a imaginação científica

Alexandra de Brito Mariano

\section{V - Temas de Recepção}

O espaço físico como alegoria da tragédia humana. Concepção do espaço dramático na Trilogia de Édipo de J. de Castro Osório

Ália Rosa C. Rodrigues

Releituras de um passado grego: a tragédia Oedipus Tyrannos de Sófocles

Rogério José de Souza

Uma velha África: Heródoto e o ensino de História da África

José Maria Gomes de Souza Neto

Elaboração da luz no espaço entre a igreja visível e invisível no pensamento

de Kant. As raízes platónicas e utópicas do modelo original

Giovanni Panno

Descobrir com jovens: espaços e paisagens do Truculentus de Plauto

Adriano Milho Cordeiro

Reflexos do espaço de exílio ovidiano no Livro do Desassossego

Rodolfo Pais Nunes Lopes

Ambiência clássica em invectivas às ditaduras militar e salazarista

Carlos Morais

O mundo clássico nas Vidas Apócrifas de Amadeu Lopes Sabino:

alguns paralelos imaginados

Glaucianne Silva dos Santos Heuer

Observação filosófica e contemplação poética das paisagens em Lucrécio 
O mito de Orpheus. A plasticidade do mito nas vozes de Virgílio, Vinícius e Camus

Elaine C. Prado dos Santos

Espaço e paisagem em Doze Naus de Manuel Alegre

José Ribeiro Ferreira

Índice de palavras-chave 


\title{
II VOLUME
}

Antiguidade Tardia e Idade Média

\author{
Humanismo \\ Temas de Recepção
}


III - AnTiguidade Tardia E Idade Média 


\title{
INTERPELAÇÕES ENTRE ESPAÇO E PAISAGEM UMA LEITURA DAS CONFISSÕES DE AGOSTINHO
}

\author{
Teresa Santos \\ Universidade de Évora \\ CIDEHUS
}

\begin{abstract}
Questioning space in Augustine's Confessions
If an ontological approach about memory (Confessions: L. X) and time (Confessions: L. XI) is required Augustine emerges as reference. However space (spatium), a concept articulated to memory and time, has no problematic impact. It is refereed just has an opposition to nothingness so it is perceptible, measurable and ordered. Above all it is understand as an extension (extensio). Why it isn't a philosophical problem to Augustine? May be because memory and time are both physiological extensions, they are not physical one. Space has just a metaphorical meaning and one occurrence in Confessions (L. X; XI). However in Augustine's first dialogues space has a particular importance as place. Gardens are particular spaces: dialogical places; conversion places.
\end{abstract}

Keywords: Augustine, Confessions, memory, time.

Palavras-chave: Agostinho, Confissões, memória, tempo.

A memória e o tempo constituem duas temáticas nucleares na ordem da reflexão augustiniana, co-determinantes do conhecer e do pensar, que são modelarmente questionadas, respectivamente, nos livros X e XI de Confissões. Para montar as interrogações metafísicas que perpassam uma e outra temática, Santo Agostinho recorre ao espaço como dimensão multireferêncial da memória e do tempo. É sobretudo ao nível da explicitação e da representação, quer imaginária quer metafórica, que o espaço se propícia funcionalmente como estrutura de suporte com suficiente plasticidade articuladora e integradora. Contudo, apesar de ser uma dimensão fundacional e estruturante, está por investigar como intervém racional e simbolicamente na interpretação das duas temáticas e, sobretudo, no todo da obra. Não é este o momento para uma tal incursão investigativa. Mas por as paisagens se inscreverem no espaço e por ele serem condicionadas, importa considerá-lo. A que paisagens nos referimos? Tềm expressão na obra augustineana? Esta é a elucidação que se impõe e que propomos avançar.

No primeiro e no segundo momento seguir-se-à o percurso do sentido protagonizado por 'espaço' nas Confissões, articulando-o com memória, do qual é indissociável. No último momento far-se-a uma paragem em algumas descrições que acolhem paisagens linha de continuidade do período do Cassicíaco. 


\section{A noção de espaço: o apuramento de sentidos 1.1. O espaço (spatium) é extensão (extensio); a memória não é espaço}

Para interpretar o acto gnoseológico Platão havia introduzido a presença de dois mundos correlativos qualitativamente diferentes: um com estatuto exemplar e transcendente - o mundo das ideias reais; outro como imagem projectada daquele - o mundo das coisas sombreadas. A deslocação nesses mundos e a transição de um para outro mundo fazia-se pela superação sucessiva de segmentos e planos num longo percurso esforçado em ordem à inteligibilidade da Verdade, que vulgarmente se denomina por itinerário ascético. A filiação neoplatónica de Agostinho comprometera-o, desde logo, quer com a estruturação e representação espacial baseadas no paradigma cosmológico dualista, quer com a noção de percurso, modo preferencial de se deslocar processualmente no espaço e com carga simbólica fortíssima. Todavia a sua conversão ao cristianismo levou-o a retratar-se da adesão a certas teorias, como as maniqueias, a rejeitar modelos interpretativos da realidade e a adoptar ou pressupor princípios que se ajustassem ao contexto metafísico da Criação, tais como os princípios transcendentais ${ }^{1}$ da relação e da diferença entre o Criador - Deus -, e as criaturas - por exemplo, mundo e ser humano -. Implicitamente a conversão de Agostinho determinou-lhe a alteração das significações que apropriara da concepção neoplatónica da realidade, promovendo a reavaliação dos comuns sentidos de compreensibilidade da mesma e procedendo a reconfigurações convergentes. Tal exercício racional, que confere a santo Agostinho um estatuto singular e uma medida extraordinária, pode ser ilustrado com a análise dos conceitos memória e tempo desenvolvida nas Confissões. Os dois conceitos admitem-se, acriticamente, como correlativos a espaço: a memória devido ao avolumar arquivístico ganho durante o longo processo mnésico; o tempo por subentender uma plataforma para a efectivação do movimento cronológico e lineal dos entes. Ora,e esta é a questão que primeiro se avança, o conceito de espaço beneficia da reflexão focalizada na memória e no tempo e desenvolvida nos livros X e XI das Confissóes? Dá Agostinho uma definição de espaço significativa e geradora de problematização equiparável ao nivel definicional alcançado com o tempo? Há que averiguar.

No livro XI das Confissóes encontra-se formulada a mais célebre pergunta sobre o tempo: "O que é, pois, o tempo? Se ninguém mo pergunta, sei o que é; mas se quero explicitá-lo a quem mo pergunta, não sei”. Não existe pergunta correspondente, com a mesma pregância, para o espaço. Desta forma se reconhece não se afigurar problemático e que a ideia corrente, abstraída da experiência empírica, é consensual e suficiente que baste. Assim o espaço tão-só designa uma extensão tridimensional, de densidade e amplitude variável, dada

\footnotetext{
${ }^{1}$ A aplicação do termo "transcendentais" aos princípios referidos justifica-se por serem necessários e universais à racionalidade.

2 "Quid est ergo tempus? si nemo ex me quaerat, scio; si quaerenti explicare uelim, nescio" (Cf. Conf., XI, XIV 17).
} 
a conhecer pelo posicionamento e movimento, particular e geral, dos entes mundanos e astrológicos. A conformidade de Agostinho à ideia corrente de "espaço" impossibilita que o termo se configure com a autonomia substantiva própria do conceito e seja discutido em interacção e equidade. É sempre sob o modo referencial que "espaço" se apresenta e são as funções contextuais que lhe vão especificando distinções.

Étienne Gilson, autor do conhecidíssimo estudo intitulado Introduction à l'Étude de Saint Augustin, dá conta do desinteresse de Agostinho por "espaço". Afirma que a memória, entendida como faculdade do pensamento, é "étrangère à toute spatialite” 3 . À partida, seria o contrário. A aptidão arquivística da memória $^{4}$ e a sua incontida elasticidade permitiriam concebê-la espacialmente como um espectacular edifício projectado por Escher, labiríntico, transformista e inescrutável ao tempo. Todavia Gilson, que insiste em afastar a memória de qualquer realista arquitectónica tridimensional, associa-a de seguida, sem largar o texto augustiniano, à extensão. Escreve que a memória "peut conserver en elle la represéntation d'étendues spaciales immenses qui coexistent ainsi sans s'entre-êmpecher mutuellement" ${ }^{5}$. Ou seja, a memória tem a possibilidade de nela se representarem, por abstração, imensas extensões coexistentes. Como aceitar esta impossibilidade desconcertante de o não representável na extensividade a memória - admitir em si representações de coisas extensíveis? Por analogia, é nesta contradição que melhor se proporciona o momento para aproximar a memória ao pensar (cogitatio), o qual também não é extensível mas considera em si o conhecimento de realidades extensíveis. A Gilson importa, conservandose fiel ao modelo trinitário da antropológica augustiniana, fortalecer o vínculo entre a memória e o pensar, duas funções espirituais estruturantes do ser humano. Ao desanexar espaço de memória e ao afirmá-la próxima do pensar, a sua constituição daquela ganha consistência racional.

Mas a tentativa de Gilson para despacializar a memória parece ser frustrada numa passagem das Confissóes, talvez a mais topologizada e pictorizada de todo o livro sobre o conceito. Transcrevemos o mínimo: “(...) e dirijo-me para as planícies e os vastos palácios da memória, onde estão tesouros de inumeráveis imagens

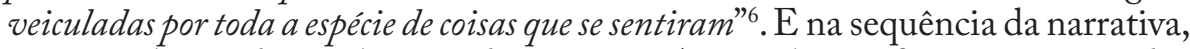
uma vez alcançadas as planícies da memória, Agostinho confronta-se com todas as imagens das coisas a jogarem interactivamente às escondidas e ao apanha num espaço que desenha uma clareira de vidência. Também transcrevemos a passagem que se lhes refere: "Quando ai estou, peço que me seja apresentado aquilo que quero: umas coisas surgem imediatamente; outras são procuradas durante mais tempo e são arrancadas dos mais secretos escaninhos; outras, ainda, precipitam-se em tropel e, quando uma é pedida e procurada, elas saltam para o meio como que

${ }^{3}$ Cf. Étienne Gilson, 1982: 137.

4 A expressão "função arquivística" acomoda-se à tradução das primeiras linhas de Conf., X, VII 13, segundo uma linguagem actual.

${ }^{5}$ Cf. Etienne Gilson, op. cit. p. 137.

${ }^{6}$ Conf, X, VII 12. 
dizendo: "Será que somos nós?»" Esta imaginativa descrição performativa, a querer dar conta de experiências próprias da condição humana - precisamente a impossibilidade de encontrar sempre o se que pretende e a necessidade de reconhecer diferencialmente o que se pretende - dificulta a despacialização da memória que Gilson pretende operar. De facto, à topologização inicial introduzida pela referência às planícies e palácios acresce agora, em reforço, a atenção à ocorrência dos movimentos, à variedade das imagens e à ludicidade mnésica, ou seja, uma sensibilização geográfica própria de quem está no lugar preciso de encontros e acontecimentos. A força narrativa de Agostinho é tão atractiva que faz esquecer a presença do registo imagético, um recurso com uma semântica pictórica reveladora de interacções intimistas. Ou seja, a espacialização da memória torna-se resistente à tentativa de desconstrução sa espacialidade.

O efeito sugestivo da espacialização da memória conseguido pela forte expressividade imagética do estilo narrativo do Bispo de Hipona confirma-se noutros parágrafos do mesmo livro das Confissóes, nomeadamente os reservados à busca de Deus. E confirma-se pelo uso do termo 'espaço' ('spatiatus') encontrado no texto em latim mas que a tradução portuguesa (uma excelente tradução, diga-se já) exclui por obstaculizar a clareza da frase. Em vez do uso de "espaço" deu-se preferência a uma perífrase. Seja como for, leia-se o que Agostinho escreve: "Eis quanto me alonguei (ou, em aproximação literal, "me espacializei") na minha memória, procurando-te, Senhor, e não te encontrei fora dela." ${ }^{8}$. Duas ideias se constituem aqui e justificam o recurso ao termo 'espaço': a interioridade do sujeito cognoscente e o valor cognoscitivo das incursões interioristas. Mais uma vez se verifica que, mesmo em referência directa, a espacialização da memória é um recurso imprescindível à construção da filosofia augustiniana por privilegiar a interioridade, instância activa do ser humano. Tal também se manifesta com o uso do advérbio de lugar "onde", colocado sob a forma interrogativa, para exprimir a circunstância da busca Deus, no suposto de ser possível determinar-lhe um lugar na memória (memoria dei). São dois os momentos do discurso confessional que merecem ser recortados do texto: "Mas onde estás na minha memória, Senhor, onde é que nela estás?"; "Então onde é que eu te encontrei para te aprender?” ${ }^{0}$. Uma e outra interrogação realçam a busca sem rota traçada, que se intensifica à medida que se vai 'adentrando' na recordação e se persiste na evocação. Se, tal como Gilson propõe, se descolar a espacialidade da memória e desconsiderar o construto imaginário que a linguagem traduz, então outra leitura se obtém: a memória é uma potência humana, a par da

${ }^{7}$ Cf. Conf., X, VIII 12. A par da ludicidade outras possibilidades da memória são enumeradas no texto: ordenar, situar, vivificar e projectar. No seu conjunto acentuam a dimensão espacial da memória. Por razões óbvias deixam-se de parte.

8 "Ecce quantum spatiatus sum in memoria mea quaerens te, domine, et non te inueni extra eam" (cf. Conf., X, XXIV 35). Sublinhado acrescentado.

9 "Sed ubi manes in memoriam ea, domine, ubi illic manes? quale cubile fabricasti tibi? quale sanctuarium aedificasti tibi?” (cf. Conf., X, XXV 36).

10 "Ubi ergo te inueni, ut discerem te?" (cf. Conf., X, XXVII 37). 
cogitação e da vontade, cuja densidade se avalia à medida que a interioridade se experiência abrindo horizontes de sentido. Tal experimentação e expressão da experimentação requerem extensividade. Logo, a memória deve usufruir de propriedade extensiva. Porém a leitura emprestada de Gilson não fornece um argumento decisivo. Vejamos se se obtém por outra abordagem.

\subsection{O tempo é extensão psicológica; o espaço é extensão cosmológica; a memória é extensão}

Resta verificar se o livro XI, conhecido pela abordagem focada no tempo, fornece dados para clarificação de espaço e suas correlações. São três as enunciações problematizadoras do tempo aí encontradas: a primeira, que o tempo é uma criatura; a segunda, que o tempo é uma distensão da alma; a última, que o tempo pressupõe memória. Atendamos a cada enunciação, tomando-a em relação com espaço.

O radicalismo da doutrina criacionista, expresso na fórmula "ex nibilo", determina que todo o existente tenha o estatuto de criatura. Neste sentido compreende-se a afirmação Agostinho: “(...) não estava criada nenbuma criatura antes de ser criada alguma criatura" 11 . Ora, como tudo o que foi criado é denominado criatura, então o tempo, que também foi criado, senão o absoluto existencial de Deus seria uma impossibilidade ${ }^{12}$, é uma criatura. Outras criaturas são, por exemplo, os céus e a terra, a luz e as trevas, que apareceram no primeiro dia da criação ${ }^{13}$. A todas elas é comum a ideia de extensão que por um lado finitiza a criatura e por outro pontualiza a sua dimensão no todo do universo. Não tendo a extensão emergido nos seis dias do processo criacional em concreção singular, não é uma criatura, porém está presente com inerência em todas as criaturas e permite determiná-las por delimitação. Ao delimitar a extensão estabelece um espaço de linearidade tridimensional, postulado na cosmologia finita da física clássica assimilada por Agostinho. Por conseguinte, o espaço definido pela extensão não é uma criatura com identidade igual a tempo nem a correlação com tempo alguma vez alcança o nível da problematização.

A segunda enunciação de tempo aborda-o como uma distensão da alma, deixando implícita uma referência à extensão. Convém lembrar que Agostinho põe de parte a teoria aristotélica do tempo calculável ou medível segundo a fórmula " $\mathrm{T}=\mathrm{V}$ (velocidade do objecto em movimento) $\mathrm{x} \mathrm{E}$ (o espaço percorrido), e ainda introduz a teoria do tempo subjectivo, cuja medição é impossível de efectuar. Como se sabe da própria experiência, a decorrência de cinco minutos passados na cadeira do dentista tem uma extensão diferente de cinco minutos passados em conversa agradável. $O$ factor de interferência na alteração da extensividade, ora dilatada ora fugidia, é tão-só de ordem psicológica. Daí

11 "(...) quod nulla fiebat creatura, antequam fieret ulla creatura" (cf. Conf., XI, XII 14).

${ }^{12}$ Leia-se: "E tu [referindo-se a Deus] não precedes os tempos com o tempo: se assim não fosse, não precederias todos os tempos" ("Nec tu tempore tempora praecedis: alioquin non omnia tempora praecederes") (cf. Conf., XI, XIII 15).

${ }_{13}$ Génesis, 1, 2-5. 
que Agostinho proceda, numa crítica implícita à linearidade da consciência, à substituição dos três modos temporais comuns - passado, presente, futuro - pelas três modalidades de presentificação do tempo - presente do passado; presente do presente; presente do futuro ${ }^{14}-\mathrm{e}$, por sua vez, pelas três modalidades vivênciais do tempo - memória; atenção; expectação $0^{15}$. Relativamente à questão em causa, a saber, se a segunda enunciação de tempo encontrada nas Confissóes fornece elementos para a conceptualização de espaço, então apenas se consegue apurar que a extensão está sujeita à variabilidade das condições psicológicas.

A última enunciação refere que o tempo psicológico pressupõe memória. Ora a propósito desta já se estabelecera que se trata de uma potência abordável pela via narrativa, sendo a espacialização factor integrante mas sem equivalência conceptual. Coloca-se então a questão: são previsíveis alterações a este registo com a tomada de perspectiva a partir da indissolúvel ligação do tempo à memória? Para Agostinho chama-se passado à vivência psicológica da presentificação das coisas passadas arquivadas na memória, posto que o passado em si não existe. Em rigor, o tempo passado é a memória. Se a memória não tem extensão e o passado é memória e em si não existe, então ao passado não pode ser atribuída extensão. Esta concordância de assentimento lógico afigurase contraditória em relação ao facto de se poder perspectivar cronologicamente o passado e disso se dar conta na linguagem, particularmente através da flexão verbal, mas mais grave, ser contraditória com a vivência da presentificação do passado, variável de pessoa para pessoa e em cada pessoa. Impõe-se uma rectificação: à memória tem de ser atribuída extensividade compatível com a possibilidade de recordar os acontecimentos passados, qualquer que seja a sua natureza. A extensão vem permitir a exteriorização e ampliação do passado, ou seja, a sua recordação. É neste sentido, e claramente situado no quadro psicilógico, que Agostinho afirma: "nem é longo o tempo passado, porque não existe, mas um passado longo é uma longa memória do passado"16. Afinal só no livro XI se decide a favor da memória como extensão e se reconhece o acerto da afirmação de Gilson sobre a possibilidade da memória, que não sendo espaço, pode conservar nela representações de extensões coexistentes.

Todo o percurso feito até aqui serviu para confirmar que em Agostinho não se reproduz a triangulação entre os termos espaço, memória e tempo. Em vez de espaço cosmológico, é a extensividade que tem valor operatório, sobretudo quando se considera a via da interioridade.

Resta apurar a existência de outros vestígios contextualizadores de espaço.

14 "Uma coisa é agora clara e transparente: não existem coisas futuras nem passadas; nem se pode dizer com propriedade: há três tempos, o passado, o presente e o futuro; mas talvez se pudesse dizer com propriedade: há três tempos, o presente respeitante às coisas passadas, o presente respeitante às coisas presentes, o presente respeitante às coisas futuras" (cf. Conf., XI, XX 26).

15 "Mas como diminui ou se extingue ofuturo que ainda não existe, ou como cresce o passado que já não existe, senão porque no espirito, que faz isso, há três operações: a expetativa, a atenção e a memória?" (cf. Conf., XI, XXVIII 37).

16 "neque longum praeteritum tempus, quod non est, sed longum praeteritum longa memoria praeteriti est" (cf. Conf., XI, XXVIII 37). 


\section{O jardim e a paisagem ajardinada}

A noção de espaço pontua nos primeiros livros das Confissóes referido a lugares de vivências e a concretas considerações do mundo. A escola, as ruas, os balneários, as vinhas e o teatro, entre outros, são lugares da infância e da adolescência de Agostinho. Refere-se-lhes como quem lhes arranca a epiderme dos sentimentos registados e revive-os para se rever a si mesmo. A dramática confessional, sempre desencadeada pela métrica do excesso ou pecado, desenrola-se a partir desses lugares. É sobre uma topografia concreta vivificada opela memória que Agostinho reconstitui a cartografia da alma. Um complexo terreno com curvas e níveis, com recantos capazes de surpreender e estimular, com simulações realistas, e enlaçado por um horizonte de infinitude. A alma humana, com toda a sua complexidade e vitalidade, é a grande paisagem que Agostinho perscruta.

Mas há outros lugares. Os jardins. Estão associados à busca de sentido para a existência e à descoberta ${ }^{17}$, o que não lhes poupa a carga dramática. Entre Setembro de 386 e Março de 387, o jardim foi para Agostinho o lugar de uma abissal experiência precedida por angústia e perturbações físicas. Referimonos ao jardim da casa de Cassíciaco, a quarenta e nove quilómetros de Milão, onde descansava na companhia da mãe, Mónica, do irmão Nivrígio, do filho Adeodato e de alguns amigos. Agostinho recorda: "Havia um pequeno jardim na nossa morada (...). O tumulto do coração levara-me para lá, onde ninguém impedisse o violento combate que comigo mesmo tratava"18. Este mesmo jardim é descrito como um cenário, com variações, em alguns dos diálogos que publicou em avulso, como $O$ Mestre, $A$ Felicidade, $A$ Ordem. Neles a pormenorização da descrição demora convenientemente para instaurar o prelúdio dialógico de tradição socrática, entretanto fornece um qualquer elemento para desenvolver o diálogo, numa concordância magistral entre a técnica pedagógica e a literária. O jardim constitui-se, pois, como lugar de circunstância convivêncial e de esclarecedor exercício racional, com recortes de paisagem modelada e regulada pelas mãos do jardineiro. Nas Confissões o jardim, precisamente o mesmo jardim de Cassiciacum, é dispensado da descrição. Não tem paisagem, ou melhor, não interessa à narrativa a visualização dos elementos paisagísticos. Importa evitar a dispersar descritiva dos elementos botânicos ou de acontecimentos bucólicos e favorecer a concentração no que nele acontece de excedente. O jardim emerge, não como o lugar social do diálogo, mas como metáfora de um útero invertido que em vez de forçar o sujeito a sair, força-o a entrar, em tumultuosas tentativas e definitiva 'conversio'. Algo que Agostinho refere nestes termos: "eu apenas enlouquecia, sem perder o juizo, e morria, sem perder a vida, desconhecendo o que de mal havia em mim, e desconhecendo o que de bem iria haver dentro de pouco

17 Também é num jardim que encontra Ambrósio, a quem procurara para confidenciar os erros e estudar o evangelho. Encontrou-o a ler em silêncio, uma novidade técnica que desconhecia.

${ }^{18}$ Conf., VIII, VIII 9. 
tempo." ${ }^{19}$. Pode-se comentar que para a conversio se efectivar apenas cabe à vontade ter vontade sobre si própria, ou seja, fazer coincidir em mesmidade temporal o quer e o fazer ${ }^{20}$. Todavia importa sublinhar o duplo sentido de jardim como clareira de vivência intensificada, propícia quer à emergência da mais expressiva fragilidade humana, o desespero elouquecedor, quer ao encontro de loucura amorosa. Nele coincide um ponto de viragem ontológica.

Que ressonância perdurou na cultura ocidental deste jardim das Confissóes, despido de paisagem mas intenso e propício à metamorfose? Certamente não passou despercebido às correntes místicas, em particular às mais voláteis e ilusionistas. O jardim/deserto, de uma beleza geométrica - linhas, formas, volumes -, configura o espaço ideal da inquietude reflexiva e da descoberta decisiva que a literatura adoptou como palco da dramática humana.

A terminar, não se pode deixar de observar, em jeito de autocrítica, que se abordou aqui o que a Agostinho desinteressou: espaço e paisagem. De algum modo se pretendeu fazer omoleta sem ovos; antes regressar a um texto tão perturbador que torna sustentável as interrogações que ele próprio não faz como a articulação de Espaço e Paisagem e qual o sentido desta articulação. Ora, voltar a ler as Confissões sem os apoios da reflexão desenvolvida é arriscar a compreensibilidade do texto. Se tal sucedeu, apresentam-se desculpas com as palavras do Bispo de Hipona: "Poucas são as coisas que exprimimos com propriedade, muitas as que referimos sem propriedade, mas entende-se o que queremos dizer" 21 .

\section{Bibliografia}

Santo Agostinho (2000), Confissões, Ed. Bilingue, Trad. Arnaldo do Espírito Santo, João Beato e Maria Cristina Pimentel. Lisboa, Imprensa Nacional - Casa da Moeda.

Correia, Pedro (2001), «A semântica de "espaço” nas Confissões», As Confissões de S. Agostinho. 1600 anos depois: Presença e Actualidade. Lisboa, U.C.P.

Gilson (1982), Étienne, Introduction à l'Étude de Saint Augustin Paris, Vrin.

Maria Cândida Pacheco (1978), «Tempo e memória em Santo Agostinho», Revista Portuguesa de Filosofia, 36-54.

${ }^{19}$ Conf., VIII, VIII 19.

${ }^{20}$ Conf., VIII, IX 21. A teoria das duas vontades.

21 "pauca sunt enim, quae proprie loquimur, plura non proprie, sed agnoscitur quid uelimus" (cf. Conf., XI, XXI 27). 


\title{
ESPACO E FRONTEIRAS DO MUNDO ROMANO NA ANTTIGUIDADE TARDIA. CONTINUIDADE E RUPTURAS EM RELAÇÃO À EUROPA ACTUAL ${ }^{1}$
}

\author{
Paula Barata Dias \\ Universidade de Coimbra
}

\begin{abstract}
Late antiquity was, for the Roman World, the period of larger formal expansion, in geographical, political and cultural terms, but also the moment of great challenges: internal disaggregation, and the menace the barbarians entering in the Roman limes. This work is intended to illustrate the importance of the facts from late antiquity and Roman political measures on the contemporary configuration of Europe, who inherited the Roman efforts to preserve unity and a stable model of civilisation.
\end{abstract}

Keywords: Late Antiquity, barbarians, Constantinople, Europe, frontiers, Rome.

Palavras-chave: Antiguidade Tardia, bárbaros, Constantinopla, Europa, fronteiras, Roma.

Em 410, S. Jerónimo recorda, numa carta dirigida a Principia, o verso que Lucano criara Quid satis est, si Roma paruum est? - "O que satisfaz, se Roma não basta?". No seu contexto original, este verso aludia ao comportamento do general Pompeu na Guerra contra Júlio César, mas Jerónimo actualizou os seus referentes, considerando que este verso sintetiza o "poder da cidade de Roma". Em novos e dramáticos tempos, quase cinco séculos passados após o final da República, S. Jerónimo resolveu reescrevê-lo: Quid saluum est, si Roma perit? - "O que pode ser salvo, se Roma perece?"2. No confronto entre estes dois versos, S. Jerónimo interpreta a história romana comparando dois momentos históricos bem distintos, unificados todavia pela mesma ideia de Roma, em que esta é apresentada como condição vital e intemporal para as existências individuais e colectivas, com uma centralidade cósmica, cujo fim, improvável no verso de Lucano, temido na leitura de Jerónimo, arrasta todo um desastre civilizacional.

S. Jerónimo partilha com as elites políticas e administrativas, militares e mesmo religiosas que serviam o Império, a vivência de uma nova realidade,

\footnotetext{
${ }^{1}$ Este trabalho foi desenvolvido no âmbito da preparação da disciplina de Matrizes Clássicas da Cultura Europeia, que leccionamos na licenciatura de Estudos Europeus na Faculdade de Letras de Coimbra.

${ }^{2}$ S. Jerónimo Epistolae 127, 12 (San Jerónimo, Epistolario,J. Bautista Valero ed. e trad. 2 vols. Madrid, BAC, 1995). Diz ele, ainda capitur urbs quae totum cepit orbem "É conquistada a cidade que conquistou o mundo inteiro"; Lucano, Bellum Ciuile, 5. 274.
} 
preocupante quando comparada com os tempos áureos de Lucano. A ameaça externa às fronteiras de Roma, aos seus interesses e áreas de influência - que atingiram, no séc. III e IV, a sua dimensão máxima - conduziram os esforços romanos a uma estratégia de defesa e de sobrevivência diante de um inimigo concertado no seu poder destrutivo. Amiano Marcelino deu disso conta numa das suas Histórias:

Hoc tempore uelut per uniuersum orbem romanum, bellum canentibus bucinis, excitae gentes saeuissimae, limites sibi proximos persultabant. Gallias Raetiasque simul Alamanni populabantur; Sarmatae Pannonias et Quadi; Picti Saxonesque et Scotti, et Attacotti Brittanos aerumnis uexauere continuis; Austoriani Mauricae aliae gentes, Africam solito acrius incursabant; Thracias et diripiebant praedatorii globi Gothorum. Persarum rex manus Armeniis iniectabat (... $)^{3}$.

A partir do séc. III foi visível a estratégia defensiva que anima o esforço bélico romano, como pode constatar-se na aclamação com que os exércitos recebem a nomeação imperial de Probo Augusto:

"Probe Auguste dii te seruent (...) exemplum militiae, exemplum imperii. Dii te seruent. Adsertor rei. Felix imperes, magister militiae felix imperes (...) tuere nos rem publicam; bene tibi commitimus, quos ante seruasti. Tu Franciscus, tu Gotbicus, tu Sarmaticus, tu Parthicus, tu omnia (...) si recte cogitemus, non nobis Aurelianus, non Alexander, non Antonini, non Traianus aut Claudius requirendi sunt (...) enim uero quae mundi pars est, quam ille non uincendo didicerit? Testes sunt Marmaridae, in Africa solo uicti, testes Franci, in inuiis strati paludibus, testes Germani et Alamanni, longe a Rheni summoti litoribus. Iam uero quid Sarmatas loquor, quid Gothos, quid Parthos ac Persas atque omnem Ponticum tractum?"4.

Nestes finais do séc. III, o bom imperador é um líder militar, capaz de pacificar os remotos territórios de Roma e de afastar deles a ameaça bárbara.

${ }^{3}$ Amiano Marcelino, Historiae 26.4 5-6 (Loeb Classical Library, Harvard, 1972, t. II, p. 588). A tradução é da nossa responsabilidade: "Nesse tempo, como se por todo o mundo romano tivessem ecoado as trombetas da guerra, crudelíssimos povos se ergueram e assolavam as fronteiras que lhes eram próximas. Os Alamanos ocuparam ao mesmo tempo as Gálias e a Récia; Os Sármatas e os Quados as Panónias. Os Pictos, os Saxões e os Escotos, e também os Atacotos causaram danos continuados às tropas britânicas; Os Austorianos e outros povos mouros deslocavam-se em África com mais furor do que o habitual; hordas predadoras de Godos delapidavam as Trácias. O rei dos Persas lançava exércitos contra as Arménias...”.

${ }^{4}$ Scriptores Historiae Augustae, 28. 11.2 -12.2 (Bibliotheca Teubneriana, 1932, t. II, p. 211): "Probo Augusto, que os Deuses te protejam (...) exemplo para os exércitos, exemplo para o Império. Que os Deuses te protejam! Protector da nação! Que afortunado governes, ó Chefe dos exércitos, que afortunado governes (...) defende o Estado por nós. Confiamos de bom grado em ti, nós que já antes salvaste. Tu vencedor dos Francos, tu vencedor dos Godos, tu vencedor dos Sármatas, tu vencedor dos Partos, tu de todas as regiões vencedor! (...) em bom juízo, não precisamos de um Aureliano, nem de um Alexandre, nem de um Antonino, nem de um Trajano ou um Cláudio (...) de facto, existe alguma parte do mundo conhecida como não tendo sido por ele vencida? São testemunhas os Marmáridas, derrotados em solo africano, são testemunhas 
A segurança do Estado e a continuidade de Roma estão condicionadas pelos acontecimentos militares na periferia do Império, particularmente nas fronteiras do Oriente. Estes territórios, tão distantes do espaço ocidental, romanizado e estabilizado desde o séc. I a. C., foram lugar de condicionamento e de definição do próprio destino de Roma, e consequentemente afectaram o curso da nossa história enquanto herdeiros do legado romano. Demografia, recursos económicos, concentração urbana, particularmente nos territórios helenísticos, tornaram-nos vitais para Roma, e estratégicos na medida em que eram o único território em que esta verdadeiramente se confrontava com civilizações avançadas e potencialmente rivais, como os Persas, os Sírios e os Egípcios.

Estamos, contudo, pouco sensibilizados a considerar, dentro do legado histórico e civilizacional de que somos descendentes, a parte oriental do mundo romano. Neste domínio, a perspectiva do homem europeu típico seguiu a memória da Queda do Ocidente em 476, e de todos os acontecimentos históricos e religiosos que acentuaram a divisão do espaço romano antigo em duas partes, a ocidental e a oriental, e que trouxeram com eles uma concepção bem mais restrita e mais limitada da nossa geografia de referência e da nossa identidade civilizacional. Estas, desde o fim do Ocidente Romano, passando pelo aparecimento das primeiras nações europeias nascidas do sangue bárbaro cristianizado e romanizado, até ao projecto carolíngio, confinaram-se à margem noroeste do Mediterrâneo, ao Latim como língua de comunicação e de cultura, e ao modelo romano do cristianismo.

Em relação ao mundo antigo, politicamente romano, culturalmente grego e latino, e religiosamente diverso, incorporaram-se perdas e ergueram-se fronteiras geográficas e simbólicas que tornaram o nosso mundo, quando comparado com o antigo império romano, mais restrito e mais fragmentado, apesar dos esforços do último século para promover as vantagens do retorno a uma união política sob a UE.

Além da fragmentação do espaço romano antigo ocorrido desde o avanço na Idade Média, o que hoje é perfeitamente verificável pela diversidade linguística e pelo número de Estados europeus que deram lugar à unidade romana, surgiram novas exclusões e novas fronteiras que não existiam no mundo romano. São facilmente reconhecidas para nós, mas não existiam no passado. A fronteira islâmica, no Médio-Oriente e na África do Norte, separanos hoje de um território anteriormente integrado no império romano, mas também, já dentro da Europa política, a do cristianismo ortodoxo e de alguns países eslavos ${ }^{5}$.

os Francos, estendidos em pântanos insalubres, são testemunhas os Germanos e os Alamanos, repelidos para longe das margens do Reno. E o que direi dos Sármatas, o que direi dos Godos, dos Partos e dos Persas e de todo o conflito no Ponto..."

${ }^{5}$ Em 2003, J. Le Goff (L'Europe est-elle née au Moyen Age. Seuil, Paris, 2003) descreveu a Europa da Idade Média como resultado de uma progressiva restrição da identidade civilizacional do horizonte romano anterior. A Europa passou a significar as nações de rito romano até ao mar do norte. 
No mundo globalizado de hoje, que em teoria devia ser menos sensível aos argumentos de pertença a um grupo restrito, estão bem patentes algumas destas fronteiras que têm a sua origem nos acontecimentos da Antiguidade Tardia e da Alta Idade Média.

Por exemplo, o projecto político da União Europeia, que nasceu após a II Guerra mundial e reúne actualmente vinte e sete Estados situados dentro das fronteiras geográficas da Europa, está, na sua realização concreta, mais de acordo com a visão da Idade Média para a Europa, isto é, uma realidade política e religiosa comum - uma espécie de clube de nações do Ocidente e do Centro europeu de tradição cristã - do que com o mundo imperial romano, tal como este se configurou, entre o séc. I e o V. Esta constatação, que resulta da simples observação, não deixa, de suscitar curiosidade a quem adopta a perspectiva de um classicista. E permite-nos colocar de sobreaviso, ou pelo menos questionar a legitimidade da nossa auto-representação, nós como cidadãos da União Europeia, como herdeiros do mundo antigo.

Assim, de que herança romana se considera herdeiro o homem europeu, quando mais de dois terços do império romano, na sua amplitude, abarcaram espaços para além das actuais fronteiras políticas, económicas e culturais do espaço europeu?

Os acontecimentos da história transformaram a realidade civilizacional do mundo greco-romano, que se manteve operativa e eficaz ao nível abstracto e mais genérico dos símbolos e dos rituais do poder, verdadeiro património cristalizado de que nos servimos - mas irrelevantes para a funcionalidade das instituições políticas actuais e mesmo para a psicologia colectiva ${ }^{6}$. Temos vários exemplos dessa distância em relação à efectiva adopção de uma mundividência similar à do mundo romano. Por exemplo, o centro político da União Europeia, dito o coração da Europa, onde pulsam as Instituições Europeias, identifica-se grosso modo com o território nullius hominum entre a França e a Alemanha, o mesmo cuja centralidade estratégica na história europeia ficou definida desde a supremacia franca no séc. IX. Este espaço foi, nos séculos posteriores e até ao séc. XX, disputado palmo a palmo, constantemente empapado pelo sangue dos soldados das nações que o disputavam ou que o atravessavam. No entanto, para o mundo greco-romano, este território confinava com a periférica margem sul do Baixo Reno, a mesma que sofreria com os assaltos bárbaros na Época Tardia e que seria concedida como local de assentamento para tribos bárbaras foederatae, de tal modo estava distante das prioridades de Roma.

Outro exemplo da nossa distância em relação à mundividência grecoromana surge da discussão, perfeitamente actual, sobre a possibilidade da integração na União Europeia de países de maioria religiosa não cristã, como

\footnotetext{
${ }^{6}$ Pensamos em realidades tão banais como o destino do nome Caesar, presente no Kzar das Rússias e no Kaiser alemão; no argentus, denarius e no solidus romanos, presentes no argent francês, no dinheiro português e no dinar de Marrocos; no vocabulário das intituições políticas nas línguas europeias, quase todo de raiz greco-latina.
} 
a Turquia, a Albânia, ou mesmo Israel, e de países com uma parte significativa do seu território noutro continente, o asiático, como a Turquia e Israel, ou em África, como os países do Magreb. Se o argumento de pertença ao mundo greco-romano e de partilha desta herança fossem operativos, se, de facto, a União Europeia fosse, de algum modo, uma recuperação da unidade romana antiga, estavam os países mencionados mais legitimados à integração europeia do que os países escandinavos, bálticos e eslavos ${ }^{7}$.

Também os Estados do Norte de África, particularmente o território que hoje é a Líbia e a Tunísia, pertenceram ao Império Romano desde as Guerras Púnicas. De romanização antiga e sólida, foram vitais fornecedores de recursos materiais e agrícolas, juntamente com o Egipto, que se tornou província romana ainda no séc. I a.C. Na África Romana floresceram as ciências e as letras gregas e latinas, particularmente em redor de Alexandria, mas também de Hipona e Tagasta, com autores brilhantes como Orígenes e Agostinho. Aí a Bíblia se tornou texto verdadeiramente universal, com a sua tradução do Hebraico para o Grego em Alexandria, com as suas primeiras traduções para Latim, na África Ocidental do séc. II. Não obstante toda esta herança cultural, a possibilidade de integração destes países num projecto político comum que validasse a herança desse passado identitário é ainda mais remota do que no caso da Turquia ou de Israel.

De facto, a cultura pós-romana identificou estes povos do Norte de África como "os berberes", ou seja, os barbaroi ou barbari, os habitantes da Barbária, ou da Berbéria, termo e realidade introduzida na língua latina no séc. VIII e IX após as incursões islâmicas a partir do Norte de África ${ }^{8}$. Portanto, a elevação desta fronteira, que não existia no mundo antigo, data, pelo menos, desta Alta Idade Média.

Também os escritores bizantinos do séc. VI chamaram de Sclavoi os invasores nómadas que assolaram a Macedónia e a Tessália, e a região de que eram procedentes de Sclabenia, ou seja, os "Eslavos" e a "Eslavénia", região geograficamente identificada com a actual Polónia. Este topónimo está presente nos nomes actuais de países da Europa Central, Eslovénia e Eslováquia, por exemplo. O Latim Medieval, particularmente os escritores francos, transliteraram os termos gregos, e o etnónimo sclaui passou a ser extensivo para um tipo particular de utilização que era dada a estas pessoas, que era a de serem sclaui, ou seja "servos". Se o Português distingue, em forma e em sentido, "escravos" e "eslavos", já o Inglês tem termos parónimos, slave e Slav que conforme são pronunciados e escritos designam uma realidade ou outra. Ainda que alguns considerem esta etimologia controversa, note-se que

\footnotetext{
${ }^{7}$ Limitamo-nos a citar exemplos de países em que, em diversos momentos e com diferentes graus de discussão, foi manifestada a possibilidade da integração na UE.

${ }^{8}$ Termo adaptado do Árabe barbar, que por sua vez o recolheu do Grego. Na língua portuguesa, de acordo com J. P. Machado, o termo está documentado a partir do séc. XIV (Barbaria) e séc. XV (berbere) para identificar "o mouro sedentário, que vive da agricultura”. O nome gentílico "Barbo" tem esta origem.
} 
a mais meridional das nações eslavas, a Sérvia, conserva na sua designação o termo latino para escravo, "seruus". Isto é "terra fornecedora de servos". Em algum momento, portanto, este etnónimo Slav, além de ter migrado para o sentido de "escravo", foi apropriado por povos de matriz latina, que assim produziram o topónimo "Sérvia". São estes dois exemplos muito concretos de como a linguagem cristalizou fronteiras e imagens do outro diferentes em relação ao património clássico comum.

A toponímia da Europa actual está também bastante marcada pela memória das turbulentas deslocações populacionais iniciadas na Antiguidade Tardia, que se prolongaram até ao final da Alta Idade Média. Regiões como a Lombardia em Itália, a Borgonha em França, a Andaluzia em Espanha, a Saxónia na Alemanha, conservam na sua designação a marca de "local de assentamento", respectivamente, de Lombardos, Burgúndios e Vândalos. Para o último caso, a Saxónia é o local de origem dos Saxões, que colonizaram maciçamente a Inglaterra no séc. $\mathrm{V}$ e que justificaram o abandono romano da Britânia do seu limes setentrional. A França é, etimologicamente, o local de assentamento dos Francos, uma das tribos germânicas a quem primeiramente foi concedido o direito de se instalar em território romano ${ }^{9}$. Anglos e Jutungos, numa $2^{\text {a }}$ fase de invasões ocorridas do séc. V ao VII, deram origem, respectivamente, à Anglia à Jutlândia, a actual Dinamarca.

Além deste superestrato, a toponímia europeia preserva, em alguns casos, o adstrato, ou seja, os nomes dados pelos romanos aos povos que consigo estabeleciam contacto. Assim, a Toscânia é a terra dos Tusci ou dos Etruscos; o País Basco é a terra dos uasconii, ou basconii; a Germânia é a terra dos Germani, embora nas línguas românicas domine o etnónimo Alamania, isto é, a terra dos Alamanos, bárbaros cujas movimentações ocorreram no séc. V.

Considerar estes factos, pode levar, numa primeira leitura, à relativização do impacto da experiência romana sobre o espaço europeu, na medida em que a geografia política reproduz um mundo nascido após o domínio romano. $\mathrm{Na}$ verdade, é justamente o contrário, na medida em que o desenho actual da Europa se construiu em redor do acontecimento axial da sua história que foi o período romano, merecendo particular destaque o período crítico da ruptura política. O termo da unidade de Roma e sua memória ficou para sempre associada à génese dos povos, regiões e de nações europeias.

Nasceu também nesta Antiguidade Tardia romana a primeira leitura do termo "Europa" como uma entidade política e administrativa própria, noção que só voltará a ser materializada no séc. XX. Nos finais do séc. III, esta correspondia a uma das seis províncias administrativas da Diocese da Trácia, na parte oriental do Império Romano, região fortemente militarizada na margem Sul do Danúbio, fronteira que foi assolada pela primeira vaga goda. Podemos confirmá-lo pela ocorrência do termo na Historia Augusta, mas também

\footnotetext{
${ }^{9}$ Charles Verlinden (1954), "Frankish Colonization: A New Approach”, Transactions of the Royal Historical Society, 4 1-17.
} 
pelo Catálogo de todas as Dignidades Civis e Militares de Roma, porventura o documento que mais objectivamente atesta esta interpretação ${ }^{10}$ :

\section{Provinciae:}

Orientis quindecim:

Palaestina. Foenice. Syria.Cilicia.Cyprus.

Arabia [et dux et comes rei militaris]: Isauria. Palaestina salutaris. Palaestina secunda. Foenice

Libani. Eufratensis. Syria salutaris. Osrhoena. Mesopotamia. Cilicia secunda.

Aegypti quinque:

Libya superior. Libya inferior. Thebais. Aegyptus. Arcadia.

Asianae decem:

Pamfylia. Hellespontus. Lydia. Pisidia. Lycaonia. Frygia Pacatiana. Frygia Salutaris. Lycia.

Caria. Insulae.

Ponticae decem:

Galatia. Bithynia. Honorias. Cappadocia prima. Cappadocia secunda. Pontus Polemoniacus.

Helenopontus. Armenia prima. Armenia secunda. Galatia salutaris.

Thraciae sex:

Europa. Thracia. Haemimontus. Rhodopa. Moesia secunda. Scythia.

Segundo a Historia Augusta, Flávio Cláudio escreveu ao imperador guerreiro Aureliano solicitando-lhe auxílio para defender a "Europa" dos Godos: "Gothi oppugnandi sunt, Gothi a Thraciis amouendi. Eorum enim plerique Haemimontum Europamque uexant, qui te pugnante fugerunt. Omnes exercitus Thracicos, omnes Illyricianos totumque limitem in tua potestate constituo". O mesmo incansável Imperador, depois de ter vencido a revolta de Persas, Arménios e Sarracenos unidos pela Imperatriz Zenóbia de Palmira, abandonou a Síria e retorna à "Europa", região onde fixara os seus exércitos. Aí, ocupado com assuntos da "Europa", descurou um novo levantamento sírio, com quem havia antes estabelecido um tratado. Enquanto permaneceu na "Europa", derrotou tribos nómadas que vagueavam pela região ${ }^{11}$.

Já um dos seus sucessores, o Imperador Probo, recebeu os europenses exercitus com os quais se dirigiu para as Gálias a fim de expulsar Francos e Alamanos ${ }^{12}$. Esperaríamos que o Imperador liderasse os “exércitos de Roma”. Qual era então

\footnotetext{
${ }^{10}$ Historia Augusta, 26, 17. 2 Aurelianus (270-275), (Teubner, t. II, p. 161). Quanto ao Catálogo das Dignidades..., ver o texto, na edição de Otto Seeck http://the latin library.com/notitia.html, Notitia Dignitatum. Berolini, Weidmann, 1876. Podemos encontrar mais informação sobre este texto em J. Salisbury (1927), "On the date of the Notitia Dignitatum", The Journal of Roman Studies, 17 102-106. Goodburn, Bartholomew eds. (1976): Aspects of the Notitia Dignitatum. Oxford, British Archeological Reports, sup. XV, 224, pp.; Bury (1920), "The Notitia Dignitatum", The Journal of Roman Studies, 10 131-154.

${ }^{11}$ Ibid., 30-31, p. 171-172: "Pacato igitur Oriente in Europam Aurelianus redit uictor atque illic Carporum copias adflixisset, cum illum Carpicum senatus absentem uocasset"; "Aureliano rebus Europensibus occupato..."; "Securior denique iterum in Europam redit atque illic omnes, qui uagabuntur, hostes nota illa sua uirtute contudit".

${ }^{12}$ Ibid., Probus 28, 13, 10, p. 213.
} 
a natureza destes "exércitos da Europa"? $\mathrm{Na}$ verdade, esta designação aplicase às tropas que estavam sedeadas na região e que se mantinham na estrita dependência do Imperador. Quando Constantino derrotou os Godos, em 332, estes foram aceites como foederati com a missão de defenderem a fronteira do Danúbio $^{13}$. Era política corrente neutralizar a ameaça constituída por algumas tribos bárbaras na proximidade do limes romano pela concessão do direito de passagem e mesmo de instalação, como povo foederatus ou hospitalarius, dentro do território romano. Estes povos tornaram-se fornecedores regulares das legiões romanas, particularmente nas regiões mais sensíveis ${ }^{14}$. Assim, segundo o relato do Historiador, nos finais do séc. III, da militarizada região do Danúbio tinham sido enviadas legiões comandadas por Probo, para defender a Gália.

Estas teriam seguramente uma constituição maioritariamente bárbara, o que pode dar um sentido ominoso à expressão europenses exercitus: tropas de constituição romano-bárbara, que pugnavam mais pelo ideal de Roma do que propriamente pela sua manifestação concreta enquanto cidade capital de um império ${ }^{15}$. Esta transferência ou apropriação da simbologia e da linguagem do poder romanas pode ser documentada no período carolíngio, associada aos atributos dos imperadores e seus exércitos que, na qualidade de descendentes dos bárbaros que sobrevieram à experiência romana, se distinguem por

${ }^{13}$ Hagith Sivan, (1987) "On Foederati, Hospitalitas, and the Settlement of the Goths in A.D. 418", The American Journal of Philology, 108. 4 759-772, p. 761: "Constantine concluded another foedus whereby the Goths were to supply auxiliary forces. Furthermore, they not only served in the Constantinian army, but also contributed to civil projects, such as the building of Constantinople."This was not a new phenomenon in itself, since soldiers were closely involved in non-military projects throughout the history of the later Roman empire." Este artigo estuda o nascimento do reino visigodo com capital em Tolosa em 418, sob a autorização romana, e mostra como esta política de acomodação dos povos bárbaros no império romano tinha sido praticada já por Constantino na pacificação das fronteiras do Danúbio desde o séc. III. Godos e Francos contam-se entre os povos que melhor beneficiaram desta forma de romanização.

${ }^{14}$ E. Luttwak, (1976), The Grand Strategy of the Roman empire from the first century A. D. to the third. Baltimore, John Hopkins U.P., 255 pp. Nesta obra, o autor descreve três diferentes estratégias romanas de preservação das suas fronteiras. No Alto Império, de Augusto a Nero, a procura de Estados clientelares no perímetro externo de Roma. No segundo, desde a dinastia dos Flávios até aos Severos, o estabelecimento de linhas defensivas bem definidas, apoiadas em numerosos efectivos militares. A terceira, desde a crise do séc. III até meados do séc. IV, pelo aparecimento de exércitos regionais, dependentes de efectivos bárbaros estabelecidos no interior do limes romano.

${ }^{15}$ A expressão europenses exercitus aqui não significará, portanto, "o exército que defende a Europa" e sim "o exército originário da província da Europa". O uso de auxiliari era corrente desde o início do Império. Teodósio I (379-395) e os seus sucessores adoptaram a política de permitirem a entrada em bloco de tribos bárbaras, que recebiam pagamentos em troca de serviço militar. Na verdade, a receptio de tribos bárbaras foi já usada por Constantino, que permitira aos francos instalarem-se como laeti "soldados agricultores" no Baixo Reno. Fundada nos mecanismos da hospitalitas, esta política teve consequências desastrosas após a invasão goda de Roma, em 410. Em 418, foi permitido a este povo assentar, com permissão romana, num reino independente na Aquitânia. Roma alienava pela primeira vez o Sul da Gália como território romano. Thomas Burns (1994): Barbarians within the Gates of Rome: A Study of the Roman Military Policy and the Barbarians, a. 375-425 A.D. Bloomington, Indiana University Press, pp. 417, p. 152. 
restaurar sob a evocação de Roma um império "na Europa" de dimensões supra-nacionais ${ }^{16}$.

De facto, o enfraquecimento do poder centrífugo da cidade de Roma é um dos fenómenos associados à Antiguidade Tardia. $\mathrm{O}$ aparecimento de novas capitais provinciais, a importância estratégica dos acontecimentos militares em partes longínquas do império e particularmente a sua divisão em duas metades foram medidas administrativas que visavam adaptar o modelo romano a novas circunstâncias. Diocleciano percebeu que a instabilidade política interna, a vastidão geográfica do Império e a ameaça dos rivais, particularmente da Pérsia, eram incompatíveis com o exercício monocrático do poder. Assim, o modelo da tetrarquia, nascido com Diocleciano nos finais do séc. III, apresentava dois Augustos, o próprio Diocleciano no Oriente e Maximiano no Ocidente, que dividiam o Império a meio e partilhavam os atributos imperiais, apoiados por dois Césares, Galério e Constâncio Cloro. Estes senhores preferem locais estrategicamente relevantes, mas periféricos em relação a Roma: Milão, no sopé sul dos Alpes, Nicomédia, a actual Izmit do Norte interior da Turquia, enquanto os Césares assentam em Trier, no Sul da actual Alemanha, e em Sirmio, na actual Bósnia. Segundo Ferdinand Lot, o abandono de Roma como sede imperial, não tendo sido definitivo no séc. III, marcou o fim de Roma e o nascimento da Romania ${ }^{17}$.

À morte de Diocleciano, sucedeu o caos entre os aspirantes ao trono, a que a restauração do modelo imperial monocrático por Constantino pôs fim, em 312, com uma vitória militar sobre o seu rival, Maxêncio. O restauro da unidade, contudo, não devolveu a centralidade a Roma, e Constantino erigiu a sua nova capital na mais extrema das províncias da Trácia, precisamente a Europa. Falamos, claro, de Constantinopla, a actual Istambul, a "cidade para onde todos os caminhos confluem" ${ }^{18}$. Não deixa de ser irónico, no actual contexto político

${ }^{16}$ Em 799, o Papa Leão III pediu auxílio ao Rei Franco, Carlos Magno, para recuperar o controlo sobre Roma, a sede papal. Como recompensa, o Pontífice sagrou-o, na noite de Natal de 800, Imperador do Sacro Império Romano, restaurando a Ocidente a linhagem imperial interrompida em 476. Um poeta anónimo referiu-se a Carlos Magno como Pater Europae para celebrar este auxílio do imperador franco na defesa do Papa. (MGH Poetae Latini Aeui Karolini, I, pp. 366.381). A mesma expressão Europenses Exercitus foi usada por Isidoro, autor da Continuatio Hispana, aplicando-a aos exércitos do avô de Carlos Magno, Carlos Martel, que em Poitiers susteve o avanço meteórico do Islão vindo da Península Ibérica. Os militares francos e o seu imperador adquiriram uma aura supra-nacional que viria a ter consequências na investidura carolíngia como imperador de Roma e na sua celebração como "Pai da Europa" (Alessandro Barbero $2000^{1}$. Charlemagne Father of a Continent. University of California Press, Berkeley, (A. Cameron trad., 2004), p. 75.

${ }^{17}$ Ferdinand Lot (1991), O Fim do Mundo Antigo e o Princípio da Idade Média. Lisboa, Ed. 70, (1 $1^{\mathrm{a}}$ ed. 1927), p. 33.

${ }^{18}$ Quando é que a Europa enquanto parte administrativa do Império Romano do Oriente transferiu o seu nome para a realidade maior que está subentendida nas expressões europenses exercitus ou pater europae, associadas ao restauração do modelo imperial Supra-Nacional por Carlos Magno? O que aconteceu nos quatro séculos que medeiam as duas concepções que possa explicar esta mudança de sentido? Propomos algumas respostas, puramente especulativas: por um lado, a Europa enquanto entidade geográfica característica surge já identificada na época 
europeu, que a província da Diocese da Trácia chamada Europa seja quem com mais legitimidade etimológica e mesmo histórica pode reclamar esse nome.

O restauro da unidade imperial por Constantino não foi, contudo, definitivo, e o modelo bicéfalo, restaurando a fronteira de Diocleciano, foi mantido pelos seus sucessores. O longo reinado da Pars Orientis por um dos mais brilhantes sucessores de Constantino, Teodósio II (408-450) contribuiu para tornar o modelo imperial de "impérios gémeos", um império greco-latino, efectivo, e não uma mera resposta a uma crise temporária ${ }^{19}$.

Não estava, contudo, na intenção dos governantes, a perda da uniformidade administrativa, da comunicação, e mesmo da solidariedade entre as duas partes, o que nos indicia que a perda do Ocidente em 476 deve ter sido vivida por Zenão, o Imperador do Oriente, como uma experiência dramática, como aliás a persistência do seu sucessor Justiniano na recuperação dos territórios ocidentais no séc. VI poderá denunciar. Dois documentos históricos datados desta época confirmam este propósito de manter a unidade imperial ao nível ideológico, mas também pragmático.

A Notitia Dignitatum, documento que já referimos, está composto de duas partes, a Notitia dignitatum omnium, tam civilium quam militarium in partibus Orientis e a Notitia dignitatum omnium, tam civilium quam militarium in partibus Occidentis ${ }^{20}$.

Este documento, uma lista exaustiva das designações das autoridades civis e militares do Império romano segundo a organização de Diocleciano, estando acompanhado da circunscrição geográfica e da hierarquia, constitui

romana. Amiano Marcelino, Historiador Romano (333-392) nascido em Antioquia (Works, 3 vols. Loeb Classical Library, Harvard, 1952-1956), confirma as informações da Historia Augusta e da Notitia Dignitatum quanto ao termo "Europa". No livro 22, 8, "Descriptio Thraciarum et Sinus Pontici regionumque ac nationum Ponto adiacentium", 22, 8, 4; 22, 8, 26; 22, 8, 42 . No livro 27, 4 "Describuntur populi et VI prouinciae Thraciarum singularumque clarae urbes". Entre as seis províncias da Trácia (as referidas na Notitia Dignitatum, supra cit.), temos (27, 4, 12) "Europa omnium ultima praeter municipia urbibus nitet duabus, Apris et Perintho, quam Heracleam posteritas dixit". Duas vezes, no entanto, o entendimento do termo é menos preciso, coincidindo na geografia com a ideia que temos de "Europa como península projectada a Ocidente da Ásia". O problema maior da circunscrição geográfica da Europa prende-se com o estabelecimento claro de uma fronteira a Oriente. O texto de Amiano Marcelino dá conta dessa dificuldade. Assim, no livro 17, 7, 4 fala-se do Atlantico Mari Europaeo fronteria ocidental incontestada. No livro 31, 2, quando se descrevem os povos bárbaros da fronteira oriental (De Hunorum et Alanorum aliarumque Schitbia Asiaticae gentium sedibus et moribus), fala-se do rio Tanaís, actual Rio Don, na Ucrânia, que separa a Ásia da Europa (13): Abundans Hister aduenarum magnitudine fluenti Sauromatas praetermeat ad usque omnem Tanaim pertinentes, qui Asiam terminat ab Europa. A novidade da Antiguidade Tardia está apenas no uso do termo "Europa" com um preciso significado político e administrativo. Já o uso carolíngio pode indiciar quer a adopção do termo geográfico para qualificar uma realidade de natureza política e ideológica, quer a adesão nostálgica ao ideal imperial de Constantino e seus sucessores que tornaram a província da Europa um lugar decisivo para a conservação de Roma.

${ }^{19}$ Fergus Millar (2005), A Greek Roman Empire, Power and Belief under Theodosius II 408450. University of California Press, Londres, p. 1-2.

${ }^{20}$ Ver n. 9. 
um documento precioso para o conhecimento real da presença romana e da sua administração. Sobreviveram quatro cópias medievais de um arquétipo que, segundo os estudiosos, teria sido copiado em Ravena em meados do séc. V. A parte relativa ao Oriente teria sido composta nos inícios do séc. V e enviada ao Imperador do Ocidente para ser completada com a descrição do território por ele administrado. Este documento teria um fim eminentemente prático e protocolar, e seria utilizado para auxiliar a comunicação e os contactos entre os agentes da administração romana, ou seja, uma versão análoga ao que hoje dispomos a partir de uma lista telefónica ou de um guia de protocolo oficial. A existência e o modo de composição deste texto, em duas fases e dois locais diferentes, com reporte do documento oriental para o lado ocidental, confirma que as duas partes do império entendiam necessário e útil o conhecimento mútuo, e mantinham, dado não haver cargos exclusivos para uma só parte, soluções uniformizadoras de administração.

Formulamos uma dúvida: teria a redacção relativa à parte ocidental sido composta apenas após a recepção do documento oriental? Dada a similitude entre os dados objectivos deste documento e o que se conhece da administração de Diocleciano a Teodósio, o documento parece reproduzir um estado da administração, e não um projecto administrativo. Neste sentido, podia ter cabido ao Ocidente preencher o texto com a sua realidade administrativa e enviar uma cópia do resultado final para Constantinopla. Não se sabe se o documento final alguma vez abandonou Ravena em viagem para o Oriente, mas, de qualquer modo, a precedência do Oriente na redacção pode constituir um argumento que denuncia o reconhecimento tácito e a supremacia real do Oriente romano sobre o Ocidente ${ }^{21}$.

O princípio da precedência de Constantinopla sobre Roma, conjugado com o propósito norteador da unidade imperial, estão também patentes no segundo documento-chave para a compreensão da História da Antiguidade Tardia. O Codex Theodosianus, a compilação que reuniu os edicta (a legislação emitida pelos magistrados), as generales constitutiones (os pronunciamentos do imperador) emitidos desde Constantino, e algumas leis de juristas clássicos anteriores seleccionadas de acordo com o seu interesse, concluído em 437, pretendeu simbolizar a unidade do império romano e cristão. Aprovado no senado, em Roma, em 438, somente dez anos depois foi oficialmente enviado ao Imperador de Ravena Valentiniano III resultou da iniciativa de Teodósio, o imperador da parte oriental. Esta compilação foi escrita em Latim, reunindo as leis posteriores a Constantino e algumas anteriores que tinham sido mantidas válidas pelo primeiro imperador cristão, a que posteriormente se agregaram as nouellae, ou seja, as leis promulgadas por Teodósio entre 437 e 450 . As leis

\footnotetext{
${ }^{21}$ Outros elementos confirmam esta leitura: o facto de a redacção relativa à parte ocidental conter mais discordâncias intratextuais e mesmo mais erros em relação à realidade arqueológica, ou quando cotejado com outras fontes, acusa numa redacção menos cuidada, ou então uma administração menos eficaz, que não era capaz de acompanhar a instabilidade nas províncias formalmente a seu cargo, mas na realidade sujeitas à turbulência do séc. V.
} 
eram subscritas pelos dois Imperadores, e dadas a conhecer, embora com um lapso de tempo, nos dois territórios. Temos, portanto, um império oficialmente romano, que utiliza o Latim como língua da administração, mesmo em áreas em que o Grego era a língua dominante da vasta massa territorial e demográfica que era a metade oriental e apesar de o seu principal promotor ocupar o trono de Constantinopla ${ }^{22}$.

Como lidou a parte oriental com a perda do seu império gémeo? Em 476, o ostrogodo Odoacro pôs fim à dinastia ocidental dos imperadores romanos, data a partir da qual se restaurou a legitimidade de um só imperador romano, ou seja, o que reside em Constantinopla. É como magister militum, ou seja como súbdito de Roma que Odoacro repôs a ordem no Ocidente, expulsando o que ele entende ser um usurpador e contribuindo para declarar nula a função do senado romano. Dispôs-se, portanto, a dar continuidade, não ao Império Romano do Ocidente, mas sim à Província de Itália, sob mandato de Constantinopla. Coube a um dos seus sucessores, Teodorico Flávio,o Ostrogodo educado em Constantinopla, dirigir ao imperador Anastácio uma significativa carta, incluída na obra de Cassiodoro, em que expõe os seus propósitos de paz em relação ao Oriente e onde reconhece o poder e a inspiração emanada por Constantinopla como legítima autoridade romana, manifestando o desejo de devolver a ordem à província da Itália, sob uma só soberania: “...nós sobretudo, que graças ao vosso divino auxílio fomos educados no vosso reino, de modo a podermos de modo idêntico exercer o poder entre os romanos. $\mathrm{O}$ nosso reino é uma imitação do vosso..."23.

${ }^{22}$ Fergus Millar, op. cit., p. 10. Citamos um exemplo desta formulação. Observe- -se a dupla autoria (Teodósio e Valentiniano), a datação segundo o costume romano, a preocupação em acautelar as falsificações e em proteger a validade das leis para todo o império, embora o local de emissão seja Constantinopla. Ou seja, temos leis aprovadas "em nome de Roma e segundo o costume romano", mas fora do espaço de Roma: IMPP. THEOD(osivs) ET VALENT(INIANVS) AA. FLORENTIO P(RAEFECTO) P(RAETORI)O ORIENTIS. (...) His adicimus nullam constitutionem in posterum uelut latam in partibus occidentis alioue in loco ab inuictissimo principe filio nostrae clementiae $\mathrm{p}(\mathrm{er}) \mathrm{p}($ etuo) Augusto Valentiniano posse proferri uel uim legis aliquam obtinere, nisi hoc idem diuina pragmatica nostris mentibus intimetur. Quod obseruari necesse est in his etiam, quae per Orientem nobis auctoribus promulgantur; falsitatis nota damnandis (...) edictis propositis in omnium populorum, in omnium prouinciarum notitiam scita maiestatis augustae nostrae faciat peruenire. DAT. XV KAL. MART. CONSTANTINOPOLI D. N. THEOD(OSIO) A. XVI CONS. ET QVI FVERIT NVNTIATVS.

${ }^{23}$ Cassiodoro, Variorum Libri XII, (PL 70, col. 714). Aurélio Cassiodoro (485-585) serviu na corte de Teodorico como questor, consul, corrector, magister officiorum, praefectus praetorio et patricius: Oportet nos, clementissime imperator, pacem quaerere, qui causas iracundiae cognoscimur non habere: quando ille moribus iam tenetur obnoxius, qui ad iusta deprehenditur imparatus. Omni quippe regno desiderabilis debet esse tranquillitas, in qua et populi proficiunt et utilitas gentium custoditur. (...) [2] Et ideo, piissime principum, potentiae uestrae conuenit et honori, ut concordiam uestram quaerere debeamus, cuius adhuc amore proficimus. Vos enim estis regnorum omnium pulcherrimum decus, uos totius orbis salutare praesidium, quos ceteri dominantes iure suspiciunt, quia in uobis singulare aliquid inesse cognoscunt, nos maxime, qui diuino auxilio in re publica uestra didicimus, quemadmodum Romanis aequabiliter imperare possimus. [3] Regnum nostrum imitatio uestra est, forma boni propositi, unici exemplar imperii: qui quantum uos sequimur, tantum gentes alias anteimus. hortamini me frequenter, ut diligam senatum, leges principum amplectar, ut cuncta Italiae membra componam. 
"Uma imitação de Roma". Ficou assim reconhecido, pelos delegados da decadente cidade do Lácio, a importância política dos acontecimentos na Europa enquanto província que albergava a nova capital e os legítimos herdeiros do Império.

Face aos elementos apresentados, pensamos ter conseguido demonstrar alguns procedimentos que justificam a permanência e a continuidade da experiência romana na Europa após o fim do mundo político romano em 476 d.C., bem como o peso efectivo dos acontecimentos da Antiguidade Tardia na configuração do mundo europeu tal como o conhecemos. De facto, Roma conseguiu, pelas medidas políticas e administrativas tomadas pelos últimos imperadores, com claro protagonismo de Constantinopla, condicionar a herança adoptada pelos sucessores bárbaros, que foram alvo de processos de aculturação e de acomodação promovidos pelo próprio império romano. Os modelos civilizacionais característicos de Roma permaneceram como referências e ideais a manter ou a restaurar pelos governantes e nações futuras, que olhavam para a experiência romana como uma construção positiva.

\section{Bibliografia}

Além da que foi referida nas notas de rodapé, foram ainda consultados:

Peter Brown (1967), “The Later Roman Empire”, The Economic History Review, 20, 2.327-343.

Walter Goffart (1981), "Rome, Constantinople, and the Barbarians", The American Historical Review, 86, 2. 275-306.

(...). Romani regni unum uelle, una semper opinio sit... 
(Página deixada propositadamente em branco) 


\title{
EL PAISAJE EN LA PEREGRINATIO EGERIAE
}

\author{
Ana Isabel Martín Ferreira \\ Universidad de Valladolid
}

\begin{abstract}
In this work, the descriptions of the landscapes along the Peregrinatio Egeriae (Itinerarium) are analysed. They are very few references to the places in the story of Egeria, since facts are more important that the scenarios where they happen. However, they are very significant and has called our attention the language used to give these kinds of details. The allusions to the natural places (rivers, mountains, vegetation) and its inhabitants have a pastoral role and some are related with the religious experience of its protagonist who, taking the Bible as a guide, on many occasions suffers what could be termed "the tourist discase".
\end{abstract}

Keywords: Egeria, Itinerarium, loca sancta, Peregrinatio.

Palavras-chave: Egéria, Itinerarium, lugares santos, Peregrinatio.

\section{Introducción}

La asignatura de Latín Vulgar en los estudios de Filología Clásica y de Filología Hispánica ha conseguido hacer del texto de Egeria una obra bastante conocida por alumnos y profesores de nuestra especialidad, y ello a pesar de los múltiples interrogantes que aún planean sobre su escrito: a la cuestión del origen de esta mujer y de su identidad, a la de su posible condición de monja, se han unido tradicionalmente los debates acerca de la época de composición, de su lengua y su estilo e, incluso, del género del relato ${ }^{1}$. Aparentemente escrito con sencillez y espontaneidad, nos revela a una mujer culta, que conoce perfectamente los textos litúrgicos y las sagradas escrituras, y que, sobre todo, utiliza la redacción como el equivalente de una cámara fotográfica, dándonos a conocer el mismo lugar desde diferentes encuadres, porque lo que le interesa transmitir, a través de la descripción de un lugar, ante la contemplación de un paisaje, es su propia emoción, el sentimiento y el optimismo con el que aborda su empresa.

Esta es la sensación que dejan traslucir sus descripciones de paisajes, pero antes de entrar en ellas, como eje central de nuestro trabajo, queremos plantear algunas cuestiones acerca del género y el título de la obra, directamente relacionadas con el tema que nos ocupa:

${ }^{1}$ De la amplia bibliografía Egeriana, nos limitaremos a señalar los trabajos y recopilaciones bibliográficas más significativos: M. Starowieyski 1979; S. Janeras 1990; V. Väänänen 1987. 


\section{Viaje, peregrinación o itinerario?}

¿Estamos ante un relato de viajes, un itinerario, o una muestra exótica del género epistolar? La tradición manuscrita ha sido en gran parte la responsable de que la mayoría de sus ediciones y traducciones se titulen "itinerario" ${ }^{2}$, pero, por otra parte, creemos que este tipo de rótulo ha sufrido la contaminación con títulos de obras semejantes, tanto por los lugares descritos (el itinerario de Pedro Diácono, por ejemplo ${ }^{3}$ ), como por la cercanía en el tiempo con nuestra autora (es el caso del atribuido a Antonino de Piacenza ${ }^{4}$ ). Sin embargo, un breve recorrido por el uso de estos dos términos en latín puede ayudarnos a decidir si se trata de una peregrinación o de un itinerario: itinerarius, adjetivo relacionado con iter, cuando se emplea como sustantivo neutro, tiene una acepción básica ${ }^{5}$, es lo mismo que commentarium itineris, o se encuentra en relación con la descripción de una expedición. Ligado a la primera noción, se utiliza itinerarium para describir recorridos, tal y como nos muestran los ejemplos del Thesaurus Linguae Latinae en esta entrada. Se combinan con el término genitivos como castrorum, provinciarum, portuum o el adjetivo maritimum. Y, en este sentido, puede relacionarse con las palabras breviarium o summarium. Podemos comprobar que, en su paso a nuestra lengua romance ${ }^{6}$, no ha sufrido demasiadas variaciones y que difícilmente encajan estas definiciones con el relato y el propósito de Egeria. De acuerdo con ellas, "itinerario" no es un título fiel al contenido de la obra". "Itinerario", como recorrido, se queda corto; pensemos en que casi siempre precisa un adjetivo que le otorgue un significado más amplio, y, así, hablamos de itinerario poético, pedagógico, curricular, turístico, etc.

En cambio, "peregrinación" no siempre necesita este tipo de adyacente; en latín, peregrinatio, designa la acción de ser peregrinus, indica el hecho de hallarse en un viaje por tierra extranjera y el hecho de viajar en general. En efecto, peregrinatio tiene en época clásica a veces un significado muy próximo al actual de 'viaje's. Además, el texto de Egeria nos permite comprobar que utiliza de manera muy diferente iter (ya que itinerarium no aparece ni una sola vez) y peregrinus (pues tampoco ha usado peregrinatio ni peregrinare). Empezando por este último, apenas se lee 2 veces en el relato: la primera, en la primera parte, cuando refiere que el obispo de Arabia es un hombre encantador que recibe muy bien a los "peregrinos": vir ... satis religiosus ... affabilis, suscipiens peregrinos valde bene (8.4). La segunda, en la segunda parte, tiene una connotación diferente, pues se trata de las trabas que se ponen a un "extranjero" para acceder al bautismo, si no aporta testigos que lo conozcan

\footnotetext{
${ }^{2}$ Cf. A. Arce ${ }^{2}$ 1996: 41; A. B. Mariano 1998: 54 y A. Moure 2000: 222.

${ }^{3}$ Cf. Itinerarium Petri Diaconi en A. Arce ${ }^{2} 1996$.

${ }^{4}$ Cf. C. Arias Abellán 2000.

${ }^{5}$ Como segunda acepción significa "toque de marcha" (signum proficiscendi); cf. ThLL, s.v.

${ }^{6}$ Cf. Diccionario de la Real Academia Española de la Lengua, s.v. "itinerario".

${ }^{7}$ Cf. A. Moure 2000: 235.

${ }^{8}$ Nos remitimos al estudio de P. Conde 2004: 65-66.
} 
(45.4). El hecho de que el mismo adjetivo tenga un significado diferente en cada una de las partes no hace sino corroborar nuestros asertos, si tenemos en cuenta que la parte del viaje propiamente dicha es la primera, pues la segunda se dedica, casi en exclusiva, a explicar la liturgia de Jerusalén. Estamos acaso ante una de las primeras utilizaciones de peregrinus como "peregrino", en sentido especializado, cristiano, para aludir al viajero que va a visitar un santuario. Este uso no se había documentado nunca en el latín clásico.

Iter, a su vez, que sólo aparece en la parte viajera del relato, se encuentra 42 veces a lo largo del texto", siempre con el sentido de "camino", "recorrido" o "viaje": en expresiones del tipo nobis erat iter o Iter sic fuit, y en combinación con los verbos reverti, ambulare, facere, habere proficisci, perexire, ire, regredi. Puede comprobarse que se ajusta al uso propio de iter en latín clásico ${ }^{10}$, entendido como "la acción de viajar, el viaje, el camino", es decir, como el movimiento y el cauce empleado para el mismo.

Estos datos nos permiten pensar que estamos, no ante un "itinerario", entendido como guía, sino ante un "camino", en sentido real y espiritual, realizado con fines cristianos por una peregrina, de la misma manera en que en la actualidad nos referimos a la peregrinación hasta Compostela como el "camino de Santiago"; dicho camino tiene mucho de viaje interior, no se puede desligar de su contenido religioso, como le sucede a Egeria. El tecnicismo que acaba empleándose para aludir a esto es "peregrinación". En esto consiste el viaje de Egeria. Egeria es una peregrina ${ }^{11}$ ad loca sancta, porque así aparecen ya denominados los lugares de destino en su texto ${ }^{12}$, que es recibida como tal por obispos y religiosos, en general, acostumbrados ya a este tipo singular de viajero que inicia la moda de visitar Tierra Santa en el siglo IV, época clave en las peregrinaciones a Palestina, especialmente entre las clases altas de Occidente convertidas al cristianismo, y que dio lugar a un fenómeno íntimamente unido a la cultura del primer monacato oriental ${ }^{13}$.

Hechas estas reflexiones en cuanto al título más adecuado para la obra, éste se relaciona con la percepción del paisaje y también con la problemática surgida en torno al género seguido por la autora: a pesar de que ha sido traducida libremente en ocasiones como Journal de Voyage, no parece que estemos ante un diario, escrito día a día, etapa por etapa ${ }^{14}$; las cosas que se cuentan, aun siguiendo un hilo conductor, son siempre retrospectivas, no cuenta los planes futuros, las referencias temporales son imprecisas. Sin ser exactamente un

${ }^{9}$ Cf. 2.3 (2 veces),4; 5.1,10; 6.3 (3 veces),4; 7.2 (2 veces),3,6; 9.4 (2 veces),5,6,7 (2 veces); $10.3 ; 12.11 ; 13.2$ (3 veces); 15.6; 16.1,2 (2 veces),3,4 (2 veces),7; 17.3; 18.1; 19.1; 21.4,5; 22.1 (2 veces); 23.6 ( 2 veces), 7.

${ }^{10}$ Cf. $T h L L$, s.v.

${ }^{11}$ Es precisamente el título del trabajo de A. Moure 2000.

${ }^{12}$ Aparece este sintagma dos veces en el texto: 15.4: ad loca sancta veniebamus; 17.2 nullus christianorum est, qui non se tendat illuc gratia orationis, quicumque tamen usque ad loca sancta..., acceserit.

${ }^{13}$ Cf. R. Gelsomino 1990: 264.

${ }^{14}$ Cf. A. Moure 2000: 221. 
diario, tampoco es un itinerario al uso, y si aceptamos que es una carta, con un destinatario colectivo (dominae venerabiles sorores, 3.8 ), debemos considerar que lo es en sentido amplio, y verdaderamente original, dado que no sigue las normas tradicionales del género epistolar. En Egeria tiene más peso su experiencia personal y el público receptor de la obra que el hecho de que esta se inscriba en un género y en una tradición literaria.

\section{El Paisaje en el relato}

Consecuentemente con la peculiaridad de este viaje, una peregrinación, y de las destinatarias del relato, se produce una especial relación con el paisaje, condicionada por la finalidad del desplazamiento a los lugares de destino y por la voluntad de transmitir las sensaciones vividas en ellos: para empezar, el entorno nunca es importante por sí mismo, sino por su significado religioso, permanece en un plano secundario. Con la Biblia de la mano, nada distrae su atención de lo fundamental: recorrer los lugares donde transcurrieron los hechos del Antiguo y del Nuevo Testamento y sentir la emoción de pisar estos sitios y ver y tocar las mismas cosas que vieron y tocaron sus protagonistas: la zarza de Moisés, el árbol sicomoro de los patriarcas, la fuente de Job, el pozo de Rebeca, el palacio del rey Abgar, etc. Su modus operandi siempre es el mismo: se trata de llegar al lugar deseado, hacer una oración, leer el pasaje bíblico correspondiente, recitar un salmo y volver a rezar (10.7).

Nunca sabemos si llueve o hace sol, si hace frío, ni los usos y costumbres de las gentes con las que se relaciona, ni la lengua que emplean para comunicarse (aunque presumiblemente casi siempre son grecoparlantes, como, por otro lado, era habitual en la parte oriental del Imperio ${ }^{15}$ ). Ni siquiera sabemos los nombres propios de sus anfitriones: tenemos la referencia del obispo de Edesa (19.5) y similares, para designar a los "reverendos monjes" que pueblan estos parajes $(19.4$, etc.). En el paisaje humano de la Peregrinatio sólo la diaconisa Marthana (23.3) sale del anonimato porque la autora, una vez más, deja traslucir la singular emoción que le produce encontrar, lejos de Jerusalén, donde la había conocido, a una amiga y hermana espiritual.

Cuando el paisaje natural cobra importancia, y pasa al primer plano, es porque se interioriza, se sitúa en otra dimensión: la espiritual. Entonces insiste una y otra vez en detalles que acentúan rasgos como la amplitud, la belleza, la altura, etc. de determinados parajes, lo cual viene indicado por el frecuente uso de superlativos: uno de los ejemplos más claros es el de la excursión al Sinaí, donde el valle que recorre es vallem infinitam, ingens, planissima et valde pulchram $(1.1)^{16}$. La insistencia en destacar las especiales dimensiones y la magnitud del lugar es clara cuando describe estos montes: tam excelsi sint quam

${ }^{15}$ En este sentido, ella recoge las palabras que ha oído in situ, como aputactites, eulogias, monazontes, parthenae o archiotipa. Cf. Väänänen 1987: 135-136.

${ }^{16}$ Cf. 2.1 y 2.2 . 
nunquam me puto vidisse... (2.6 ${ }^{17}$. Podemos notar cierta exageración, porque lo que quiere demostrar es que todo obedece a la gracia de Dios (sine Dei gratia puto illud non esse: 2.7 ), cuya ayuda le hace incluso no acusar el esfuerzo por llegar a la cima (labor non sentiebatur: 3.2). Lo que nos describe es, más allá del entorno, lo que siente un peregrino cuando llega a su meta. Para conseguir que sus lectoras lo perciban, no escatima detalles ni ahorra repeticiones. Y, si algún elemento del conjunto no se encuentra en consonancia con las magnitudes descritas, como la iglesia de la cima, no tiene reparos en acudir a la lítotes y presentárnosla, con juego de palabras incluido, como non satis grande, quae tamen ecclesia habet de se gratiam grandem (3.3).

Pero Egeria, en su práctica del "turismo bíblico", está dispuesta a ver incluso lo que no se ve, sufre lo que hemos denominado el "mal del turista", especialmente perceptible cuando describe lo que se ve desde el Sinaí, a todas luces imposible: Aegyptum autem et Palaestinam et mare rubrum et mare illud Parthenicum, quod mittit Alexandriam, nec non et fines Saracenorum infinitos (3.8).

Sucede lo mismo en el episodio del Monte Nebó, donde los guías le muestran desde la cima los lugares citados en el libro de Moisés (12.3-6): Libiada, Jericó, la mayor parte de Palestina, todo el valle del Jordán, las tierras de los sodomitas y Segor. Al final tiene que admitir, a propósito de la columna que mostraba el lugar en el que estuvo la estatua de la mujer de Lot, que no se puede ver todo (12.7): Certe locum <cum> videremus, columnam nullam vidimus, et ideo fallere vos super hanc rem non possum.

A pesar de que son escasas las descripciones paisajísticas, sí aparecen referencias a un locus amoenus en Egeria, íntimamente ligado a la presencia del agua: utiliza 5 veces amoenus, casi siempre en superlativo, las dos primeras, a orillas del Jordán: (13.2) vidi super ripam fuminis Iordanis vallem pulchram satis et amoenam, abundantem vineis et arboribus, quoniam aquae multae ibi erant et optimae satis...(13.4) Ego autem cum viderem locum tam gratum, requisivi, quisnam locus esset ille tan amenus. Vuelve a ser un valle el que así se califica cerca de Sedima y también un huerto con frutales: (15.2) coepimus ire cum eo pedibus totum per vallem amoenissimam, donec perveniremus usque ad hortum pomarium valde amoenum, ubi ostendit nobis in medio fontem aquae optimae satis et purae. Finalmente, lo es de nuevo el valle del Jordán: (16.2) in eo itinere vidimus vallem ... amoenissimam, quae vallis erat ingens, mittens torrentem in Iordanem infinitum.

El agua es el elemento más importante en la configuración de estos espacios. No se puede separar de su valor simbólico, religioso, se presenta como fuente de vida, vivificadora de paisajes, que hace crecer árboles y frutos: el huerto en el que aún vive la zarza de Moisés es gratissimum, habens aquam optimam abundantem (4.7); un lugar es agradable (gratus) porque pasa por allí un brazo del Nilo (7.8) y, en consencuencia, se habla de los fértiles campos que, bien regados, alumbran viñedos, frutales, etc. (9.4).

Pero nada resulta tan emocionante para la peregrina como beber el mismo agua que dio de beber Moisés a los israelitas: En el Sinaí (5.6) y

${ }^{17}$ Cf. 3.8. 
también en el monte Nebó (10.8 y 11.2). Son aguas casi "milagrosas" como se desprende del relato -reconstruido por la crítica- acerca de la fuente de Job (16.4b) y del que cuenta el origen de las extraordinarias fuentes del palacio del rey Abgar (19.7 y ss.).

Para describir estos elementos espaciales, Egeria renuncia, no sabemos si voluntariamente ${ }^{18}$, a la tradición literaria: las localizaciones y la ambientación de su reportaje tienen un denominador común: La Biblia. El suyo es un "viaje de libro" y no cuentan las demás fuentes ni convenciones literarias. El locus amoenus sublimado por los poetas no tiene nada que ver con el que se recrea ante los ojos del lector de Egeria, para la que es sinonimo de gratus. El lugar digno de tal nombre es, sencillamente, el que se ha sentido como tal en un momento determinado de su camino. Lejos de establecer comparaciones con los ríos, espacios y paisajes, sin duda caudalosos ${ }^{19}$, verdes y frondosos de su país de origen, estos le parecen los mejores que ha visto en su vida, y lo dice convencida, porque conforman el singular "Monte do Gozo" de esta peregrina y porque son los paisajes y los espacios de La Biblia.

\section{Bibliografía}

A. Arce (21996), Itinerario de la Virgen Egeria. Madrid.

C. Arias Abellán (2000), Itinerarios latinos a Jerusalén y al Oriente cristiano (Egeria y el Pseudo-Antonino de Piacenza). Sevilla.

P. Conde Parrado (2004), "El viaje religioso", en F. M. Mariño-Ma. O Oliva Herrer (eds.), El viaje en la literatura occidental. Valladolid. 61-80.

R. Gelsomino (1990), "Egeria, 381-384 d.C.: dalle Radici romane alle Radici bibliche", in Atti del Convegno Internazionale sulla Peregrinatio Egeriae. Arezzo. 243-304.

S. Janeras (1990), "Contributo alla bibliografia egeriana", in Atti del Convegno Internazionale sulla Peregrinatio Egeriae. Arezzo. 355-366.

A. B. Mariano (1998), Egéria. Viagem do Ocidente à Terra Santa, no séc. IV. Edição de Alexandra B. Mariano e Aires A. Nascimento. Lisboa.

A. Moure Casas (2000), "Egeria, peregrina a Tierra Santa", en V. Cristóbal-C. López de Juan (eds.), Feliz quien como Ulises. Madrid. 215-236.

M. Starowieyski (1979), "Bibliografia Egeriana”, Augustinianum 19.2 97318.

V. Väänänen (1987), Le journal-épître d'Égerie (Itinerarium Egeriae). Étude linguistique. Helsinki.

${ }^{18}$ Quizá sería sobredimensionar su formación literaria: reconociendo que era una persona culta, podemos pensar que no utiliza los recursos de los poetas clásicos para describir un paisaje bien porque no llega a dominar este tipo de entresijos, bien porque no pretende explotar lugares comunes y, en función de su público y tipo de viaje, prefiere la transmisión sincera y directa de cuanto ve, o bien por las dos razones a la vez.

${ }^{19}$ Recordemos la célebre comparación del Éufrates con el Ródano (18.2). 
(Página deixada propositadamente em branco) 
(Página deixada propositadamente em branco) 
IV - Humanismo 
(Página deixada propositadamente em branco) 


\title{
ESPAÇO E ALEGORIA \\ NA POESIA ÉPICA PORTUGUESA SEISCENTISTA
}

\author{
Manuel dos Santos Rodrigues \\ Universidade Nova de Lisboa
}

\begin{abstract}
Fundamental element of the narrative, space sometimes assumes a symbolic function which is determinant for the explanation of characters, subject and diegetic structure. The Portuguese epic poetry of the seventeenth century often favours the symbolic use of space, constructing true systems of literary allegories where space, characters and action work together to construct the ideological system that supports the text.

Vasco Mouzinho de Quevedo's Afonso Africano, an epic poem with twelve chants which narrates the conquest of Arzilla and Tanger by the Portuguese king Afonso V, is a true paradigm of this kind of allegoric epic poetry. In the text that precedes the first edition (1611), the poet explains that Afonso V's military enterprise stands for man's conquest of his own soul, a common idea of contemporaneous holy eloquence.

This study tries to determine how space, as diegetical element intimately connected with characters, action and the marvellous, is important to understanding the deeper significance of a Poem that many critics estimate to be the best after Os Lusiadas.
\end{abstract}

Keywords: Afonso Africano, allegory, Portuguese epic poetry, space.

Palavras-chave: Afonso Africano, alegoria, espaço, poesia épica portuguesa.

Em consonância com a coetânea, literatura europeia a poesia épica portuguesa da transição para o maneirismo e barroco regista um acentuado pendor alegórico, que se patenteia seja sob a forma de figuras mitológicas, seja através da personificação de ideias filosóficas, teológicas ou morais, seja pela localização da acção em espaços de carácter simbólico. Tal tendência afirmase com o Afonso Africano, de Vasco Mouzinho de Quevedo, poema de doze cantos, em oitava rima, que narra a tomada de Arzila e Tânger por D. Afonso V (1611), mas manifestara-se antes. De certo modo, Camões assume a função alegórica das figuras mitológicas ao declarar que estas só servem para fazer versos deleitosos (Lus., X.82). E sabe-se como os comentadores seiscentistas que tomaram a defesa da epopeia lusa se estribaram na interpretação alegórica para isentar o vate das censuras dos zoilos incomodados com o uso da mitologia pagã num poema cristão ${ }^{1}$.

${ }^{1}$ Cf. Maria Lucília Gonçalves Pires (1982), A critica camoniana no séc. XVII. Lisboa, ICALP (Biblioteca Breve), 24-26. Comentadores modernos como Jorge de Sena e Y. K. Centeno, entre outros, vão muito mais longe, atribuindo um sentido metafórico profundo, por vezes oculto, aos 
Posteriormente a Os Lusíadas, encontramos episódios claramente alegóricos na Elegíada, de Luís Pereira Brandão (1588), e, especialmente, no Naufragio e lastimoso sucesso da Perdiçam de Manoel de Sousa de Sepúlveda, de Jerónimo Corte Real (1594), onde ocorrem personificações como o Amor e seu irmão Antheros, a Vingança, o Ódio, a Ira, a Determinação, o Desespero, a Paciência, e espaços alegóricos, como a morada de Némesis, o Templo da Verdade e o templo da Mentira. Mas, em rigor, será necessário esperar pelo Afonso Africano para encontrarmos um poema épico de carácter estruturalmente alegórico, subordinado a uma intenção moralizante, à semelhança de obras como The Faerie Queene (1579-1589), de Edmund Spenser, ou o Libro Primeiro delos famosos hechos del principe Celidon de Iberia (1583), de Gómez de Luque, ou o Pelayo (1605), de López Pinciano, ou, ainda, e muito próximo do nosso autor, a Jerusalén Conquistada (1609), de Lope de la Vega.

$\mathrm{Na}$ esteira de Tasso, o poeta setubalense propugna pela necessidade de uma outra «alma» para o poema épico, alma que reside na alegoria ${ }^{2}$. E à semelhança de López Pinciano, no Pelayo, expõe o significado da construção alegórica do seu Poema num texto preliminar, com o título de «Alegoria do Poema segundo a fábula». Aqui se pode ler:

Ua das arriscadas empresas que há no mundo é aquela que empreende um varão forte contra si mesmo, trabalhando render e avassalar a cidade de sua alma, com que se lhe tem levantado o imigo humano. Esta se afigura em Arzila, situada ao longo do mar nas partes de África, de muros altos cercada, que dão entrada e saída por cinco portas abertas, que são os cinco sentidos. Na mais alta parte sua se levanta a torre com três baluartes, que são as potências dessa alma, $e$ no meio a fortaleza da mesquita, que éo coração humano. Esta, com frota armada vai buscando das praias de Lisboa D. Afonso $V$, o Africano, por quem este varão é figurado ${ }^{3}$.

A estrutura simbólica do Poema assenta, portanto, em dois eixos fundamentais: um eixo vertical - a representação metonímica do ser humano por um varão forte que leva a cabo a difícil empresa de conquistar-se a si mesmo -, e um eixo horizontal - a representação metafórica da alma por uma cidade fortificada. $\mathrm{Na}$ estrutura narrativa, o primeiro eixo liga-se à acção, o segundo ao espaço.

A ideia do domínio de si mesmo como base da virtude e apanágio do homem perfeito tem, como se sabe, origem nos filósofos gregos, foi estruturante da ética

vários níveis estruturantes do Poema, em especial a viagem do Gama e a história de Portugal. Cf. Maria de Lourdes Cidraes (1991-1993), «Os Lusíadas de Luís de Camões: Poesia. Mito. História», Românica. 289-304.

${ }^{2}$ Vasco Mouzinho de Quevedo expõe o seu pensamento sobre a poesia épica nos textos preliminares do Poema, em especial num intitulado «Condições do Poema», constante no manuscrito mas não inserido em nenhuma das edições. Nele afirma: «Há-de ter a fábula outra alma, a qual é a alegoria». Nados-mortos considera os poemas a que falta a alegoria, e em nome dela admite a quebra da verosimilhança, questão largamente debatida pelos teóricos e críticos do século XVI, entre eles Torquato Tasso, cuja influência na produção épica seiscentista é sobejamente conhecida.

${ }^{3}$ Afonso Africano, «Alegoria do Poema». Modernizou-se a grafia. 
estóica e passou à moral cristã. Frei Heitor Pinto, não muito distante de Vasco Mouzinho de Quevedo, expõe-na num passo do «Diálogo da Tribulação» (cap. III: Da paciência, e da vitória de si, e das armas com que se alcança esta vitória») que constitui uma tradução quase literal da admoestação de Cícero a César no Pro M. Marcello ${ }^{4}$ :

"Muitos capitães houve aí que venceram grandes exércitos em multidão inumeráveis, em crueldade bárbaros, em lugares infinitos, em todo o género de armas, mantimentos, riquezas copiosas e abundantes: mas enfim tudo isso são vitórias humanas; porém vencer a si mesmo, sopear a fúria, ter sofrimento na adversidade, perdoar as injúrias, liar-se com a paciência, isto é mais divino que humano. Esta é a mais alta de todas as vitórias, vencer um homem a si mesmo. Esta é a que entrega o nome à perpetuidade, digna de ser celebrada em todas as letras e línguas, $e$ de viver enquanto viver a memória dos mortais».

D. Afonso V, paladino da cruzada cristã, encarna este ideal ético-religioso. O mesmo conceito é, porém, extensível a outros heróis, em particular o príncipe D. João, e D. Fernando, duque de Guimarães. O príncipe passa por um processo iniciático que culmina com a sua admissão à ordem dos cavaleiros, recompensa justa para um jovem que soube superar provas como a tentação das ninfas na «ilha de deleites», sobrepondo a noção do dever ao apelo da carne. D. Fernando, figura do guerreiro invencível, em quem «se afigura a vontade à razão obediente», é premiado com a tomada de Tânger (na realidade levada a cabo por D. João, futuro marquês de Montemor ${ }^{6}$ ), «porque o prémio da vontade é andar em guerra contínua, e obrar como a razão lhe vai ditando» («Alegoria do Poema»).

Arzila, se no plano narrativo constitui o objectivo da empresa militar de Afonso V, representa, no plano simbólico, o objecto da vontade que, subordinando-se aos ditames da razão, procura o domínio das paixões e a expurgação do mal que habita o coração do homem. A cidade, descrita nas est. 11-13 do canto VIII, é apresentada como uma cidadela rodeada por um muro com cinco portas. Cada porta, ornamentada por um animal, representa um sentido: a do lince, a vista; a do cervo, a audição; a do «doméstico animal» que o «faro custumado toma», o olfacto; a do símio, o gosto; finalmente, a do animal «que presente / Consigo sempre a casa vai levando, / Cuja concha escabrosa, áspera e dura, / Da bela Vénus pisa a planta pura» ${ }^{7}$, o tacto. Na muralha, erguese uma torre com três baluartes, que simbolizam as três potências da alma (entendimento, memória e vontade). No centro da cidadela, situa-se, «forte e segura», a mesquita, a qual «com tanto artifício armada fica / Que com todas

${ }^{4}$ Cf. Cícero, Pro M. Marcello Oratio, 3,8.

${ }^{5}$ Imagem da Vida Cristã (21952), Lisboa, Sá da Costa, I vol.,. p. 232.

${ }^{6}$ Cf. Rui de Pina, Chronica do Senhor Rey D. Affonso V, cap. CLXVII.

${ }^{7}$ A concha da vieira (pecten maximus), na qual, de acordo com a lenda, Vénus foi transportada para a ilha de Chipre (ou de Citera) pelos Zéfiros, após o seu nascimento da espuma do mar (conforme se vê representado no célebre quadro de Sandro Boticelli, o Nascimento de Vénus). 
as ruas comunica», tal como o coração, que representa.

A mesquita, coração da cidade, encontra-se ocupada pelo mal, corporizado por uma «serpente horrífica» enroscada no pilar central que sustenta o edifício (XII, 82). Todas as tentativas dos cavaleiros para abater o monstro se revelam infrutíferas. Essa é tarefa reservada ao rei, como lhe diz o «puro sacerdote» a quem Afonso V pede conselho: «Para vós esta empresa está guardada, / Vós deste monstro tomareis vingança, / Se por esta água santa for passada / No ferro agudo essa invencível lança, / Que é peçonha finíssima aprovada / A toda fera desta semelhança» (XII, 89). Para a conquista da cidadela, Afonso V pode contar com a ajuda dos fortes cavaleiros que o acompanham, mas a eliminação da serpente é algo que tem de fazer sozinho, pois só cada um pode expurgar o mal de dentro de si mesmo.

Será ocioso lembrar a simbologia da serpente na tradição judaico-cristã, conotada com o pecado, de que o homem deve fugir e contra o qual deve combater. Mas, no presente contexto, a simbologia da serpente tem outro alcance, ligando-se à oposição entre o cristianismo e o islamismo subjacente ao espírito de cruzada que enforma o Poema. A serpente, símbolo do demónio, representa o mal e o mal identifica-se com os mouros, expulsos de Arzila do mesmo modo que a serpente é expulsa da mesquita ${ }^{8}$.

A representação da alma como uma cidade fortificada é frequente na literatura sacra, ocorrendo em termos muito semelhantes aos do Afonso Africano por exemplo num sermão de Santo António, onde Jerusalém quer dizer a alma e as portas são figuras dos sentidos corporais, por onde a alma sai a passear pelo mundo. A originalidade de Quevedo está em associar o mal, que é necessário erradicar da alma, aos inimigos da Fé cristã, os mouros, em cuja posse se encontra Arzila, desse modo relacionando o esforço de cada um no caminho da perfeição com o espírito de cruzada, missão histórica de Portugal. A conquista de Arzila torna-se, assim, simbólica a dois níveis: no plano individual, representa a vitória do homem sobre si mesmo, exemplificada sobretudo com a personagem de $\mathrm{D}$. Afonso $\mathrm{V}$, que elimina a serpente do templo maldito, tornado de «habitação do Inferno» em «vivo templo» do próprio Deus («Alegoria do Poema»); no plano colectivo, representa a vitória do cristianismo sobre o islamismo, materializada na consagração da mesquita em Igreja de Nossa Senhora Santa Maria da Assunção.

$\mathrm{Na}$ prossecução da sua empresa, D. Afonso V (e com ele o príncipe) encontra diversos obstáculos que é mister superar. Com tais obstáculos se relacionam espaços simbólicos de transição, como sejam o «mar tempestuoso do apetite irascível e concupiscível» (canto III) e a «ilha de deleites» (canto VI), representando o primeiro «os contrastes e asperezas que a virtude dificultam»

\footnotetext{
${ }^{8}$ Pedro de Mariz, de quem Vasco Mouzinho de Quevedo foi amigo e cuja obra conhecia bem, ao explicar as armas de Coimbra, identifica a serpente, nelas constante, com os mouros «e outros bárbaros da terra», opondo-os aos espanhóis, comparados ao leão. Cf. Diálogos de Vária História. Coimbra, Oficina de António de Mariz, Impressor da Univ., 2a edição, 1597, fl. 18$18 \mathrm{v}$.
} 
e o segundo «os deleites que retêm e obrigam muitas vezes a se não passar avante». Estes são, conforme a explicação do poeta, os dois mais poderosos «obstáculos e impedimentos que desta empresa desviam», ambos tecidos pelo Inferno com o intuito de fazer malograr o objectivo do rei português, leia-se, do «varão forte» que tem de «render e avassalar a cidade de sua alma».

Tópico comum da poesia épica (e também elemento indispensável das narrativas hagiográficas em que a viagem marítima funciona como percurso prévio da busca do paraíso, sendo aí um dos muitos obstáculos que é necessário ultrapassar), a tempestade serve, por um lado, para introduzir o episódio de Anteu e, por outro, para preparar o episódio da ilha encantada, momento fulcral da narrativa, na qual ocupa uma posição de charneira, semelhante à do canto VI da Eneida, que lhe serve de modelo estrutural ${ }^{9}$.

O episódio surge integrado no relato da viagem que Afonso de Vasconcelos faz ao capitão de Ceuta após o banquete por este oferecido ao rei. Passado o cabo de S. Vicente, o piloto, perscrutando o firmamento, percebe sinais da tempestade. Ao amanhecer, abate-se sobre a armada a borrasca, descrita em traços carregados e cores sombrias. Forma-se então «um nebuloso manto, / Sinal medonho de hórridos ensaios» (III, 85), que cobre a armada durante três dias, ao cabo dos quais surge Anteu, uma «máquina de horror», com «membros mortais», «vulto deforme», que, como o Adamastor, «dando um temeroso e forte brado», ameaça os portugueses com «casos tristes, / Com naufrágios cruéis de vossas vidas» (III, 94). Mas Afonso implora ao "Divino Sol» que lhe mostre um raio "[q]ue estas trevas desfaça e abra caminho» (III, 95), e de imediato «o Céu mostrou a estrela luminosa, / Em cuja luz e rutilante fogo / De Alcides a figura milagrosa / Se transformou, lançando um raio vivo / Com que se perturbou o monstro esquivo» (III, 97).

Anteu, representação mítica do «mar tempestuoso do apetite irascível e concupiscível», simboliza as trevas, as forças do mal que ameaçam os homens nos seus esforços para atingirem a virtude. Mas o facto de ser apresentado como senhor da África («Sou o temido Anteu, mais arrogante / Dos filhos que a fecunda Terra teve, / Este Império de Líbia tão possante / Debaxo de meu jugo sempre esteve» III, 92) liga-o inevitavelmente aos mouros, conotados com as forças infernais ${ }^{10}$.

Hércules é a luz que vence as trevas. A sua vitória sobre Anteu representa o triunfo do Ocidente sobre a África muçulmana, o triunfo do cristianismo sobre

\footnotetext{
${ }^{9}$ Como se disse, o Afonso Africano é constituído por doze cantos, seguindo, em linhas gerais, a estrutura da Eneida. Os seis primeiros são dedicados à preparação do feito central do poema, correspondendo-lhes a descrição da viagem e digressões com ela relacionada; os últimos seis descrevem as várias acções militares que levam à consecução do objectivo da expedição (com excepção de parte do canto X e todo o XI, a que corresponde a digressão sobre a história de Portugal gravada nas pinturas da caverna do mago Eudolo, com particular relevo para a batalha de Alcácer-Quibir).

${ }^{10}$ A história de Anteu é retomada no canto XII, est. 51-67, onde um velho mouro de Tânger conta a Afonso $\mathrm{V}$, a propósito da história da cidade, a tradição que a dava como fundada por Anteu e a luta em que o filho da Terra foi vencido pelo poderoso Hércules.
} 
o islamismo, o triunfo do Céu sobre a Terra (donde Anteu recobra forças). Neste sentido, Hércules prefigura o próprio Afonso V. Este, como aquele, vence as forças do mal, e tal como Hércules matou o dragão que guardava o jardim das Hespérides, Afonso eliminou a serpente que dominava a mesquita, possibilitando assim a sua a consagração.

Em consequência da tempestade, a nau que transporta o príncipe vai parar a uma ilha desconhecida, réplica da camoniana Ilha dos Amores, espaço edénico, habitado por ninfas que, em jogos de sedução, procuram reter os jovens marinheiros, impedi-los de cumprir a missão que lhes fora destinada.

Toda a descrição do espaço na «ilha de deleites» vai no sentido de acentuar, por um lado, a sua beleza tentadora, por outro, o seu artificialismo, a sua falsidade. O narrador (o príncipe D. João, que conta ao rei o que se passara após a tempestade) começa por enfatizar o desconhecimento do lugar, mesmo pelos mais experimentados mestres («Demos a caso nũa estranha parte» VI, 13; «Eu, que não conheci a estranha terra, / Dos mais práticos mestres informado, / Preguntei que parage o sítio encerra, / E de que gente pode ser pisado. / E nisto cada qual se engana, e erra / O que se tem por mais exprimentado» VI, 15), certamente para marcar, desde logo, a irrealidade do local. Mais tarde, perplexo com tanta beleza, o príncipe põe em dúvida a real existência daquele lugar, intuindo tratar-se de uma invenção infernal: «Se fantástica e vã [a ilha], para que intento? / Que ou há-de ser do Inferno ou do Céu traça. / O Céu não faz igual contentamento, / Com este o Inferno só pouco embaraça» (VI, 38).

A descrição da praia, próximo da qual assoma um prado, corresponde ao típico locus amoenus. Quando, cobertos de denso nevoeiro, os marinheiros imaginam «algũa praia áspera e feia», eis que se lhes depara «ũa praia fresca e leda», "praia alegre», de «água pura» e «branca areia», que a todos convida ao desembarque, Mas brevemente o artificialismo do lugar, associado à sua natureza enganadora, irá ser revelado. $\mathrm{O}$ prado tem duas cercas. A primeira, que «artifício parece da Natura», delimita uma «fermosa e linda praderia», onde uma grande diversidade de flores, dispostas em canteiros, apela fortemente aos sentidos e ao gozo do instante, simbolizado precisamente no colher dessas flores, todas, de uma forma ou outra, conotadas com o amor (a rosa, o narciso, o jacinto, o amaranto, o cravo, etc.). A segunda cerca, porém, «gentil cerca», é formada «[d]e rasos buxos a nível nascidos, / Com mil enredos de invenção tecidos» (VI, 21); noutra parte, está um lanço de murta «[e]m diversas figuras transformadas» (VI, 22). Os enredos e figuras desenhados nas plantas correspondem a várias histórias de amor da mitologia greco-romana (Bóreas e Oritia, Paris e Helena, Júpiter e Europa, Júpiter e Astérie, Júpiter e Leda...), de que, no entanto, só se representa a parte feliz: «Do gostoso princípio há aqui memória, / Mas não do desestrado fim da glória» (VI, 22).

A este espaço segue-se um outro, «deleitoso posto / Onde plantas de muita variedade / Pomos estão oferecendo ao gosto» (VI, 28), e logo um «vale ameno», «[p]or onde ũa ribeira cristalina / Regando vai o florido terreno / $\mathrm{E}$ alvas areias brandamente inclina. / Tão manso leva o curso, e tão sereno, / Que mal para onde vai se determina, / E o tom saudoso da água, que corria, / 
Motivo era de amor e de alegria» (VI, 29). Lugar paradisíaco, onde não faltam a «viçosa verde cana», os «frescos salgueiros», os rouxinóis que «melodia estão fazendo», as fontes que «saudosamente estão fervendo», umas brotando da branca areia, outras rompendo da pedra viva. Neste ponto, como anti-clímax de tanta beleza natural, eis que surgem figuras, esculpidas em jaspe ou mármore pário, a representar casos amorosos com fim dramático. E, culminando toda a descrição, aparece «Amor em várias formas retratado», ora menino, ora velho, ora com rosto alegre, ora em lágrimas banhado (VI, 34).

O propósito alegórico é claro. $\mathrm{O}$ espaço, edénico, apela aos sentidos, à entrega ao momento e aos prazeres sensuais, mas as formas esculpidas, seja na vegetação seja na pedra, lembram as consequências nefastas dessa entrega.

As ninfas que povoam a ilha reforçam a mensagem simbólica do episódio. A sua beleza, os seus jogos de sedução, o seu canto, arrebatam os sentidos, mas são enganadores. A ninfa que faz o elogio da beleza, da juventude e do amor, e que apela ao carpe diem, surge «arrimada a um tronco de viçosa / Hera enlaçado» (VI, 51), o que, na simbologia da literatura emblemática em que autor era versado, a associa à prostituição, ideia reforçada pelo uso do verbo vender na descrição do seu comportamento sedutor: «com passeio airoso / Pelo sombrio bosque se escondia, / C'um fingimento e furto cauteloso, / Como que em parte cara se vendia» (VI, $60)$.

Ao canto sedutor da ninfa respondem as advertências do «sermão» de Pedro, capelão da nau do príncipe. Adormecera antes do desembarque e fora providencialmente acordado pelo «arco celeste» para impedir que os jovens soçobrassem à tentação da carne. As suas palavras são o contraponto das palavras da ninfa: «Se a vida é breve, se ligeiramente / Corre o tempo, nem sempre cá se mora, / Por um gosto tão breve não se impida / Um gosto eterno de ũa eterna vida» $(\mathrm{VI}, 69)$. No discurso do sacerdote está contido o programa moral inerente ao sistema alegórico de todo o Poema: «Ninguém pode alcançar a felicidade / Se contra os apetites não trabalha» (VI, 75).

A «ilha de deleites», obra das forças infernais que se opõem à realização da empresa, como surgiu assim desaparece: por encanto. As águas submergem-na, arrastando consigo o único marinheiro que se deixara cativar pelo canto das sereias. A ilha é uma quimera, ficção poética ao serviço da alegoria. 
(Página deixada propositadamente em branco) 


\title{
A MUNDIVIDÊNCIA DE DIOGO PIRES À LUZ DA COLECTÂNEA POÉTICA DOS XENIA
}

\author{
António Manuel Lopes Andrade \\ Universidade de Aveiro \\ Centro de Linguas e Culturas \\ aandrade@ua.pt
}

\begin{abstract}
By the end of his life, Diogo Pires has published an extensive poetic compilation in Venice entitled Cato Minor siue Disticha Moralia. In this study, we seek to analyse one of the widest collections included in this work - Xenia ad Ianum Claudium Ciuem Rhacusanum -, a large assemblage of distichs inspired by the eponymous book incorporated in Marcial's Epigrammata.

If the Xenia (and also the Apophoreta) by the Bilbilis poet offer invaluable insight into Roman daily life in the $1^{\text {st }}$ century, it is also undeniable that the book by the Évora poet provides us with a vivid recollection of his personal world, revealing his inclinations and most remote memories. Diogo Pires handles a broad range of themes in an ingenious and concise manner, by resorting to plain elegiac distichs that illustrate the felicitous interweaving of two places and times: Classical Antiquity and Renaissance.
\end{abstract}

Keywords: Diogo Pires, Martial, Neolatin poetry, Renaissance Humanism

Palavras-chave: Diogo Pires, Humanismo Renascentista, Marcial, poesia novilatina.

Diogo Pires trilhou os principais caminhos da Europa de Quinhentos, depois de ter abandonado o Reino, em 1535, um ano antes do estabelecimento da Inquisição em Portugal. Filho de uma proeminente família de mercadores cristãos-novos, natural de Évora, o inspirado poeta novilatino estudou em algumas das mais afamadas universidades europeias (Salamanca,Paris, Lovaina), relacionou-se com ilustres humanistas, conheceu de perto os meandros do complexo xadrez político-religioso e económico do seu tempo.

Diogo Pires publicou na última década de Quinhentos, em Veneza, aquela que pode ser justamente considerada a sua obra-prima: uma extensa colectânea poética, em língua latina, intitulada Cato Minor siue Disticha Moralia ${ }^{1}$. O poeta

${ }^{1}$ A esta obra de Diogo Pires, dedicámos a nossa dissertação de doutoramento, subordinada ao título O Cato Minor de Diogo Pires e a Poesia Didáctica do séc. XVI. Aveiro, Universidade de Aveiro - Departamento de Línguas e Culturas, 2005 (versão policopiada). Apresenta-se seguidamente a descrição bibliográfica das duas edições venezianas da colectânea, que foi significativamente aumentada e reformulada na segunda edição, a partir da qual serão feitas, ao longo deste trabalho, todas as citações: 
eborense, já nos últimos anos de vida, dedicou o seu livro aos mestres--escola de Lisboa, a capital da sua querida pátria, que muitos anos antes o vira partir para sempre.É nosso objectivo, neste estudo, proceder a uma análise, necessariamente breve, de uma das colecções mais extensas desta obra, à qual foi dado o título Xenia ad Ianum Claudium Ciuem Rhacusanum ${ }^{2}$, um largo conjunto de dísticos inspirados no livro homónimo dos Epigrammata de Marcial.

Este conjunto de poemas é um dos mais extensos do Cato Minor, pois comporta cerca de 229 dísticos, alguns dos quais acompanhados de escólios para facilitar a compreensão dos leitores menos familiarizados com as diversas matérias abordadas. Além disso, cada poema apresenta um título próprio que, muitas vezes, ajuda a esclarecer a natureza do ser ou objecto referido. O conjunto foi dedicado a Ivan Klaudije, membro de uma antiga e reputada família de Dubrovnik, da qual faz parte também o seu irmão, Marin Klaudije ${ }^{3}$.

Os Xenia e Apophoreta, que correspondem aos títulos próprios dos livros XIII e XIV dos Epigrammata de Marcial, constituíram, sem dúvida alguma, o principal modelo em que se inspirou Diogo Pires para conceber e compor esta colecção de dísticos, à qual atribuiu, inclusive, um dos títulos antes adoptado pelo poeta bilbilitano, ou seja, Xenia ${ }^{4}$.

$\mathrm{O}$ único poema publicado entre os testimonia do Cato Minor, que não respeita aos três livros de dísticos morais com que se inicia o livro (Moralium distichorum libri III), reporta-se precisamente ao conjunto dos Xenia. Trata--se de um hendecassílabo da autoria de um médico valenciano, de provável ascendência judaica, que compara Diogo Pires a Marcial, em tom bastante jocoso:

\section{VALDAVRAE MEDICI VALENTINI IN IOBI XENIA}

Festiuissimus omnium poeta,

noster scilicet ille Martialis,

FLAVII LACOBI / EBORENSIS / CATO MINOR, / SIVE DYSTICHA MORALIA / ad Ludimagistros Olyssipponenses. / ACCESSERE NOVA EPIGRAMMATA, / E̋ alia nonnulla eodem Auctore. / Opus pium, et erudiendis pueris ad- / prime necessarium. / venETIIs, / Sub signum Leonis. MDXciI.

FLAVII / IACOBI EBORENSIS / CATO MINOR, / SIVE DISTICHA MORALIA / Ad Ludimagistros Olysipponenses. / ACCESSERE EPIGRAMMATA, / E alia nonnulla eodem auctore, quae / sequens pagella indicabit. / OPVS PIVM, ET ERVDIENDIS / pueris adprime necessarium. / Psal. 33. / Uenite flij, audite me, timorem Domini docebo uos. / venetiss, MDXcvi. / Apud Felicem Valgrisium.

${ }^{2}$ Cato Minor (1596), 43-71. D. Körbler 1917: 50-65, procede à análise temática desta colectânea poética de Diogo Pires, identificando a figura do seu destinatário. C. A. André 1992, em trabalho sugestivamente intitulado Um judeu no desterro: Diogo Pires e a memória de Portugal, apresenta e analisa várias composições desta colectânea que evocam a memória da pátria do poeta.

${ }^{3}$ Diogo Pires abre a colecção com dois poemas dedicados a Ivan Klaudije, cf. Cato Minor (1596), 43. Dirige ainda um longo poema Ad Marinum Claudium, publicado na colectânea Hendecasyllabi do Cato Minor (1596), 175-176.

${ }^{4}$ Refira-se a tradução integral dos Epigramas de Marcial para a língua portuguesa - Marcial (2000 - 2004), Epigramas. Lisboa, Edições 70, 4 vols, cujo volume IV contém o livro dos Xenia (trad. de Delfim Ferreira Leão) e dos Apophoreta (trad. de Paulo Sérgio Ferreira). 
si Flaui legeret breuem libellum,

ridens diceret: «En cinaede uerpe,

tu meam quoque Bilbilin lacessis?,

DE VALDAURA', MÉDICO VALENCIANO, AOS XENLA DE JACOB

O mais divertido dos poetas,

decerto o nosso célebre Marcial,

se lesse o pequeno livrinho de Flávio,

diria com um sorriso: "Olha lá, ó circunciso devasso, também tu provocas a minha Bilbilis?»

Os Xenia e Apophoreta foram publicados em 84/85 d. C., por ocasião dos festejos das Saturnais, celebradas durante o mês de Dezembro. Ambos contêm epigramas, geralmente de um dístico apenas, cuja função específica era acompanhar os presentes trocados entre os Romanos durante as festas em honra de Saturno. Os Xenia referem-se sobretudo aos presentes relativos a tudo aquilo que era costume comer e beber nos banquetes, enquanto os Apophoreta recolhem toda uma enorme variedade de prendas que era comum oferecer durante as festividades.

Uma simples comparação entre a colectânea do Cato Minor e os dois últimos livros dos Epigrammata de Marcial comprova, de facto, que o poeta eborense se inspirou, antes de mais, no livro dos Xenia, o que torna plenamente justificada a adopção deste mesmo título. Não é lícito afirmar-se, porém, que Diogo Pires tenha respeitado fielmente na sua obra a repartição temática existente nos dois livros de Marcial.

É um facto que os Xenia do humanista português integram inúmeros dísticos relativos, de uma ou de outra forma, às comidas e bebidas, mas não deixam também de incluir, se bem que em menor número, outros poemas sobre uma grande diversidade de matérias. Uns e outros ocupam um lugar privilegiado na colecção do poeta eborense, que no seu conjunto patenteia uma maior amplitude temática do que o livro homónimo de Marcial.

Ainda que nem sempre seja possível estabelecer muito bem o critério de ordenação dos poemas, todavia, a forma como foram publicados no Cato Minor parece indiciar que houve um critério de associação temática a presidir à sua composição e organização. $\mathrm{Na}$ verdade, os dísticos contidos nos Xenia encontram-se subordinados aos seguintes temas genéricos:

\footnotetext{
${ }^{5}$ Cato Minor (1596), fl. a7v.

${ }^{6}$ Os Valdaura são uma família de mercadores originários de Valência, para quem Juan Luis Vives começou por trabalhar como professor particular. A essa família pertencia, aliás, Margarita Valdaura com quem o famoso humanista casou em 1524. Cf. R. Marín Ibáñez 1994: 744. Não foi possível identificar com precisão o autor deste breve poema, mas é natural que seja um membro desta família.
} 
1. riquezas da natureza: pedras preciosas e madeiras exóticas (dísticos 1-21, dedicados, por exemplo, ao diamante, esmeralda, safira, ametista, coral, mármore, alabastro ou marfim);

2. reino vegetal: a) plantas medicinais e aromáticas (dísticos 22-59, dedicados, por exemplo, à mirra, incenso, tamarindo, raiz da China, âmbar, pimenta, gengibre, noz-moscada, açafrão ou mel); b) flores, plantas, frutos (dísticos 60-125, dedicados, por exemplo, à flor do Jacinto, menta, arruda, alface, malva, cebola e alho-porro, fava, melões ou castanhas);

3. reino animal: bebidas e comidas, animais domésticos e selvagens (dísticos 126-202, dedicados, entre outros, à água, vinho, queijos, javali, cisne, papagaio, andorinha, mula, peixe-aranha, ostra, pescada, cavalo, égua, burro, abelha, tigres, leão, elefante ou galo);

4. temas variados (dísticos 207-229, dedicados, por exemplo, ao gelo, neve, bombarda, surdo, cego ou mendigo).

Convém notar também que muitos dísticos do humanista português ostentam um título igual ou semelhante aos do bilbilitano, ainda que o tratamento dos temas seja, no entanto, bastante distinto em ambos os poetas. É de assinalar a existência de quatro epigramas, cujos títulos são exactamente iguais nos Xenia de Marcial e de Diogo Pires (apresenta-se, em primeiro lugar, a referência do poema de Marcial): Piper (13.5; p. 49); Lens (13.9; p. 55); Faba (13.7; p. 55); Ostrea (13.82; p. 63). Além disso, importa referir que muitos outros têm títulos assaz semelhantes em ambas as colecções: Tus (13.4) vs. Ebur et Thus (p. 46); Cydonea (13.24) vs. Mala Cydonea (p. 57); Lucanicae (13.35) vs. Lucanica (p. 59); Turdorum decuria (13.51) vs. Turdus (p. 60); Anates (13.52) vs. Anas (p. 60); Terrae Tubera (13.50) vs. Tubera et Boleti (p. 64); Numidicae (13.73) vs. Gallina Numidica (p. 68); Columbus (13.66) vs. Columbus domesticus (p. 60); Anseres (13.74) vs. Anser (p. 60); Grues (13.75) vs. Grus (p. 60), Mulli uiui (13.79) vs. Mullus (p. 61); Rhombi (13.81) vs. Rhombus (p. 61); Lepores (13.92) vs. Lepus (p. 63); Garum sociorum (13.102) vs. Garum (p. 63); Mel Atticum (13.104) vs. $\mathrm{Mel}$ (p. 50).

A relação com o modelo latino não é tão estreita como esta semelhança parece, à primeira vista, indicar, pois os temas são recriados de uma forma completamente originale independente. O espaço e o tempo muito diferenciados em que viveram Marcial e Diogo Pires explica, em grande medida, o distinto tratamento dos temas, ainda que ambos façam uso da mesma língua. Além disso, o poeta português alarga bastante o âmbito temático do seu livrinho ao compor vários dísticos sobre objectos ou seres que, de facto, não poderiam ser oferecidos, ao contrário do que sucedia geralmente nos poemas de Marcial.

A escolha e o tratamento dos temas diz bastante do mundo em que vivia o poeta eborense. Os objectos e os animais remexem muitas vezes com as suas vivências mais íntimas que lhe podem trazer à memória, por exemplo, a agradável lembrança do tordo a debicar a azeitona madura nas planícies alentejanas da 
sua infância $(\text { Turdus })^{7}$; um indivíduo que o impressionou, na cidade de Lisboa, pouco antes da sua partida $(L e o)^{8}$; um corvo de penas brancas que teve a sorte de observar em Lovaina (Coruus) ${ }^{9}$; o sabor inesquecível dos deliciosos melões de Ferrara (Melo pepones) ${ }^{10}$; a impressionante estátua de Hércules que viu em Roma, no Capitólio (Mala Cydonia) ${ }^{11}$; as ameixas secas vindas da Bósnia com os seus reconhecidos efeitos digestivos (Eadem arida) ${ }^{12}$ ou ainda a saborosa couve de Dubrovnik, colhida no mês de Outubro $(\text { Idem })^{13}$.

À semelhança dos Xenia e Apophoreta de Marcial, a colectânea do humanista português também constitui uma montra do quotidiano, não dos Romanos do século I d. C., mas do mundo de Quinhentos que Diogo Pires tão bem conheceu. Sabe-se, por exemplo, o que se comia e bebia nos vários lugares por onde peregrinou o poeta, os objectos a que era dado maior valor ou as enormes virtualidades das plantas medicinais e aromáticas.

Esta colecção poética atesta efectivamente o conhecimento privilegiado que Diogo Pires tinha dos simples e das drogas, das especiarias e da enorme diversidade de produtos e animais provenientes do vasto império português. De facto, o humanista eborense não só possuía formação em Medicina como pertencia a uma das principais famílias judaico-portuguesas envolvidas no comércio internacional de especiarias, pelo que é natural que os seus poemas evidenciem a grande familiaridade que tinha com esta matéria.

Por outro lado, convém não esquecer que no seio das relações pessoais de Diogo Pires se encontram alguns dos nomes mais reputados da Medicina do século XVI como é o caso de Amato Lusitano, Antonio Musa Brasavola, Giovanni Battista Canani ou Andrés Laguna.

Diogo Pires detinha um conhecimento privilegiado deste meio científico e dos seus actores principais. Transparece, não raras vezes, em alguns dísticos da colectânea Xenia um profundo saber tanto dos autores consagrados na Antiguidade Clássica como das obras inovadoras que marcaram a revolução científica da Medicina e da Botânica no Renascimento.

Assim, em escólio ao dístico sobre a Cariophylon flos ${ }^{14}$, demonstra conhecer a obra de Giovanni Manardi, médico de Ferrara, que designa a mesma flor de outra forma; noutro dístico, intitulado Spinaca ${ }^{15}$, alude à investigação desenvolivida por Amato Lusitano, seu parente e amigo inseparável, no sentido de saber se o espinafre era conhecido dos antigos; no poema dedicado às Castaneae ${ }^{16}$, contraria a autoridade de Galeno, defendendo as virtualidades

\footnotetext{
${ }^{7}$ Cato Minor (1596), 60.

${ }^{8}$ Cato Minor (1596), 67.

${ }^{9}$ Cato Minor (1596), 68.

${ }^{10}$ Cato Minor (1596), 56.

${ }^{11}$ Cato Minor (1596), 57.

${ }^{12}$ Cato Minor (1596), 56.

${ }^{13}$ Cato Minor (1596), 54.

${ }^{14}$ Cato Minor (1596), 51.

${ }^{15}$ Cato Minor (1596), 53.

${ }^{16}$ Cato Minor (1596), 57.
} 
da castanha como alimento; no dístico Myrtus ex Dioscoride ${ }^{17}$, reconhece as propriedades desta planta já assinaladas por Dioscórides; noutra composição, ainda, dá voz à suposição geral dos médicos de que a Febris quartana ${ }^{18}$ tinha efeitos muito distintos nos jovens e nos velhos.

Trata-se, de facto, de um conjunto de poemas bastante interessante em que o humanista português alia o seu conhecimento privilegiado da matéria tratada ao seu inegável talento como poeta. Em simples dísticos elegíacos molda temas variados, sem deixar de recorrer ao seu profundo domínio das literaturas clássicas e, em particular, da obra de Marcial.

O próprio Diogo Pires, no terceiro poema dos Xenia, revela o enorme prazer que constituiu para ele compor estes dísticos à imagem dos do Bilbilitano. De facto, é evidente que presidiu à escrita destes poemas uma perspectiva eminentemente lúdica. $\mathrm{O}$ poeta diverte-se imenso a moldar temas muito diversos num processo em que interpela, não raras vezes, a perspicácia e a capacidade do leitor para descodificar as referências mais diversificadas que vão sendo feitas ao objecto de cada um dos dísticos:

\title{
DE SABINO CRITICO
}

\begin{abstract}
Si mibi Censoris concedat lima Sabini, ut numeris unum crescat iota meis, ipse quoque audebo, quamuis lasciua repugnet Bilbilis, argutis ludere Xeiniolis. ${ }^{19}$
\end{abstract}

\section{O CENSOR SABINO20}

\section{Se a lima do censor sabino me conceder que cresça um iota nos meus versos, eu próprio também ousarei, embora me repugne a lasciva Bilbilis, brincar com as argutas prendinhas.}

Os poemas dos Xenia despertam a curiosidade do leitor e não deixam de o surpreender pela forma agradável e inovadora como é tratada a matéria poética. $\mathrm{Na}$ verdade, apenas um poeta talentoso como Diogo Pires poderia conjugar a ampla variedade temática dos dísticos, malgrado a aparente aridez de alguns motivos, com as frequentes alusões pessoais e os seus apurados conhecimentos científicos, compondo uma interessante colectânea que é fruto, em simultâneo,

\footnotetext{
${ }^{17}$ Cato Minor (1596), 53.

${ }^{18}$ Cato Minor (1596), 70.

${ }^{19}$ Cato Minor (1596), 44.
}

${ }^{20}$ Não nos foi possível identificar esta figura, se bem que possa tratar-se do mesmo indivíduo a quem está dirigida uma composição dos Hendecasyllabi - Cato Minor (1596), 185 -, com o sugestivo título de Ad Sabinum poetam iambographum et temulentum. 
das relações estreitas que estabelece, em geral, com a Antiguidade Clássica e, em particular, com a obra de Marcial.

Se os Xenia (e também os Apophoreta) do Bilbilitano constituem uma riquíssima montra do quotidiano dos Romanos do século primeiro da nossa era, não é menos verdade que este livro do Eborense permite visualizar, do mesmo modo, o seu próprio mundo, dando a conhecer as suas preferências e memórias mais recônditas. Diogo Pires molda temas variadíssimos, de forma engenhosa e concisa, em simples poemas, que são o espelho perfeito do feliz cruzamento de dois tempos e dois espaços: o universo da Antiguidade Clássica e o do Renascimento.

\section{Bibliografia}

António M. L. Andrade (2005), O Cato Minor de Diogo Pires e a poesia didáctica do séc. XVI. Aveiro, Universidade de Aveiro - Departamento de Línguas e Culturas (dissertação de doutoramento - versão policopiada).

Carlos Ascenso André (1992), Um judeu no desterro: Diogo Pires e a memória de Portugal. Coimbra, Centro de Estudos Clássicos e Humanísticos da Universidade de Coimbra - I.N.I.C.

Duro Körbler (1917), "Život i rad humanista Didalka Portugalca, napose u Dubrovniku", RAD Jugoslavenska Akademija Znanost i Umjetnost. Zagreb 1-169.

Ricardo Marín Ibáñez (1994), “Juan Luis Vives (1492?-1540)”: Prospects: the quarterly review of comparative education 14, n. ${ }^{\circ}$ 3/4 743-759. 
(Página deixada propositadamente em branco) 


\title{
ESPACCO LITERÁRIO FEMININO A OBRA DE MARIA DE MESQUITA PIMENTEL
}

\author{
Antónia Fialho Conde \\ Dep. de História da Universidade de Évora \\ CIDEHUS-UE \\ mconde@uevora.pt
}

\begin{abstract}
The literary feminine production is scarce in the modern period. In a speech fitted by the Counter-reform, the conventual's writing was allowing, specially printed, the contact with the secular world. Between the Portuguese nuns, writers, we intend to let know the work of Maria de Mesquita Pimentel, nun born in the last quarter of the XVI century in the South of the Tagus, and what saw part of his work published in 1639, entitled Memorial da Infancia de Christo eTriumpho do divino Amor. However, they remained handwritten and unpublished two parts. These Parts, $2^{\text {nd }}$ and $3^{\text {rd }}$, manuscripts, are structured along 13 Cantos (1125 octaves) and 11 Cantos (965 octaves), respectively, both in octaves with ten syllables and rhyme scheme ABABABCC. All the Cantos have an introductory octave, revealing the Author, along the speech, not only a notable verbal power and a clear influence of the coeval ideas, but also the knowledge of episodes and characters of the classic world, witch she elects and evokes to illustrate the speech and that weren't commons in the formation/education of her contemporaries' nuns.
\end{abstract}

Keywords: Barroque, counter-reformation, feminine literary, mysticism.

Palavras-chave: Barroco, contra-reforma, escrita feminina, misticismo.

\section{A Autora}

A nova glória dos Pimentéis ${ }^{1}$,Maria de Mesquita Pimentel faleceu em 1661, com 80 anos de idade 2 . O contrato de dote de sua irmã Escolástica, religiosa no mesmo mosteiro, surge na documentação de S. Bento de Cástris ${ }^{3}$, na altura com 14 anos, e foi celebrado em Fevereiro de 1612; segundo este contrato, era filha de Luís Mesquita Pimentel e de Domingas da Silva, sendo seu tutor e dotador

1"Illa Pimenteliae gentis nova gloria, / Pindo/ Nomen in excelso magnum viridantia/ Florum/ Serta gerens niveo pulsabat pectine/ Chordas,/ Infantique paras me lioa crepundia/ Verbo/ Omnia facta tener quae Tu, bone/ Christie, puellus/ Gessisti conscripta libro tibi donat:/ Amoris/ Divinique canit tenebrosa ex hoste/ Triumphos." P. A. dos Reis 1745: n. 278.

${ }^{2}$ Cf. D.B. Machado, Monarquia Lusitana, o que situaria o nascimento de Maria de Mesquita Pimentel em 1581.

${ }^{3}$ B.P.E., Cód. CXXXI/2-2, F1.221 
o tio, Francisco de Piemonte, meirinho da correição. Segundo algumas fontes ${ }^{4}$, a religiosa era dada como pertencendo ao mosteiro cisterciense de Celas, filha de João Pimentel da Silva, e originária de Estremoz.

Foi religiosa no mosteiro cisterciense de Évora. De acordo com o estudo que elaborámos sobre este cenóbio, nunca desempenhou no mosteiro o cargo de abadessa; foi duas vezes subprioresa $(1637,1643)$, e uma vez deputada $(1637,1658)$, precisamente em períodos conturbados na história local e nacional.

\section{A obra impressa}

A parte impressa da sua obra significou a sua saída do anonimato. A leitura e a escrita implicavam o domínio de conhecimentos específicos, normalmente parcos, escassos e controlados: as obras que existiam no mosteiro onde foi religiosa não abundavam, além da rigidez temática que reflectiam. Só conhecimentos adquiridos antes da entrada no mosteiro, em contextos familiares e sociais favoráveis, e eventualmente complementados com uma pequena biblioteca pessoal, explicam a sua agilidade, por exemplo a nível vocabular (ou a nível da grafia, na obra manuscrita, e na sua maior parte autografa, pensamos).

Dentro dos diversos géneros e estilos reconhecidos pelos especialistas em que a escrita feminina se expressou no período moderno, temos que a literatura religiosa, e, dentro desta, a poesia mística, teve larga expressão. Enquadrando-se neste contexto, a sua obra foi parcialmente publicada em $1639^{5}$, após aprovação do Abade de Alcobaça. Os exemplares são muito raros, mas a Biblioteca Pública de Évora conta com um deles, porém sem folha de rosto ${ }^{6}$. A obra, antes do discurso poético da Autora, obedece a uma sequência discursiva que o contextualiza: contem uma Dedicatória da religiosa a Nossa Senhora, um Prólogo ao Leitor, onde apresenta o propósito da obra, relatar a Infância de Cristo. Verifica-se aqui uma tendência comum em Seiscentos: se foi de grande devoção mariana, a figura de Cristo e a sua humanidade acaba por ser a chave desta obra: “(...) a dinâmica épica [suelo/cielo] no poema heróico de Soror Mesquita Pimentel em torno da encarnação de Jesus", que se prolonga nas partes manuscritas.

\footnotetext{
${ }^{4}$ G. Cardoso 1666: 442.
}

5 Segundo Inocêncio, em Lisboa, na Oficina de Jorge Rodrigues, 1638. “(...) In $8^{\circ}$ de X (innumeradas), 156 folhas numeradas só na frente. (...) esta enfiada de cantos mal possa classificar-se como poema de alguma genero determinado, pois que apparecem ahi violadas em tudo as regras e preceitos da arte, não deixa de ter seu merito pela ternura dos affectos, e singela elegancia da phrase em que está escripto, accusando na auctora dotes de não vulgar ingenho, e devota inspiração. A parte impressa é hoje pouco menos que desconhecida, porque os exemplares são raríssimos (...)”. I. da Silva 1862:141-143.

${ }^{6}$ B.P.E., Cota S.N., E 24, C.1. Este exemplar está autografado; a numeração e quantidade de fólios coincidem com os apontados por Inocêncio.

${ }^{7}$ Cf. I. Morujão 1998:116. 
Seguem-se vários sonetos, alguns anónimos, dedicados à Autora, onde se referencia a sua obra ${ }^{8}$, outros de religiosos cistercienses, o primeiro deles em espanhol e com epigrama, da autoria do Dr. Fr. Luís de Sá e o outro de Fr. Theodosio de Lucena. Os elogios à Autora sucedem-se, através de mais um soneto em espanhol, anónimo, " en loor de su estremada virtud, y celebre ingenio”, cinco quadras do Padre João de Teve \& Marmeleiro, e por último umas décimas do Padre Luis Mendez.

A obra estrutura-se desenvolvendo a primeira parte em 10 cantos a partir da oitava do Argumento, acabando com a seguinte oitava $\left(10,81^{\mathrm{a}}\right)$, e que enquadra as partes que até nós chegaram manuscritas: "Aqui, luz de minha alma verdadeira, /De vossa doce Infancia \& santa vida,/Tem já fim esta parte, que he Primeira, /E no meu coração fica esculpida. /Fauorecei, Senhor, vòs a Terceira, /Pois que jà vola tenho offerecida, /Aceitando o desejo, que se funda/ Em vos offerecer logo a Segunda”.

\section{A obra manuscrita}

$\mathrm{O}$ manuscrito ${ }^{10}$ desenvolve-se em duas partes, como continuação da obra impressa: uma 2a Parte, intitulada Vida e Milagres de Cristo, estruturada ao longo de 13 Cantos (1125 oitavas) e uma 3a Parte, e Memorial da Paixão de Christo e Triumpho do Divino Amor, em 11 Cantos (965 oitavas).

A história contida nos fólios iniciais do manuscrito conta um pouco do seu percurso. No fólio inicial, além da data apontada da encadernação, 15 de Março de 1653, surgem os nomes do Dr. Francisco Jorge de Castro e de Gonçalo Lopes de Carvalho, possíveis possuidores, e no rodapé, temos a indicação de outro local por onde o manuscrito circulou: Lisboa, Corpus Christi, de Carmelitas Descalços. No verso deste fólio, a indicação de que constaria da Livraria de Alexandre Metello de Souza Meneses. Detivemonos ao longo do Códice seleccionando partes do discurso que considerámos significativas (capacidade de escrita, riqueza vocabular, substância cultural do discurso, entre outras).

No Canto 2, num quadro apocalíptico, é evocada a Natureza e a sua força devastadora: “(...) Neste terrível tempo em que aquário/ Os seus diluvios d'agoa vem lançando/ E Orion soberbo e temerario/ A lus do belo sol vai eclipsando/ Quis o divino amante solitário/ Que fosse em tal lugar mais

8 "Aa Senhora Maria de Mesquita Pimentel, que despois de escrever a Paixão de Christo, \& Triumpho do diuino Amor, em oitaua rima, escreveo a Infancia de Chisto, \& Triumpho do diuino Amor no mesmo verso".

9 "Mar avilla fatal de nuestra edad/ Ya feniz os mostrais em boz sirena:/ De spues q. en bibo fuego os dexó llena/ M inardo; de su engenio, y santidad:/ Es tamas os offrece la deidad/ Quita ndo Amor de vuestra dulce vena/ Pi ramides que exalçan vuestra pena,/ Mem orias que eternizan de verdad./ Te ntand la fama que hasta aora muda/ $\mathbf{L}$ a boz offrece ya, que al te[m]plo llama/ De sus aras por victima, el oluido:/ Raro tendreis el nombre, que sin duda/ Ingenio inuentarà la antiga fama/Y arte para os dar lo que es deuido." Respeitámos os intervalos e sublinhámos as iniciais para tornar mais perceptível a mensagem.

${ }^{10}$ B.P.E., Cód.406 Manizola. 
scintilando/ De seu suave amor ardente chama/ Que sempre mais padece quem mais ama/" $\left(2,14^{a}\right)$.

A mesma linha inspiradora, com a Bíblia como claro hipotexto, encontra-se nas oitavas seguintes. Desta forma nos surge o diálogo entre Belzebu e Lucífer, em plena disputa do fictício morgado que é a Terra, e da humanidade de Cristo, que contra eles combate. $\mathrm{Na}$ luta, Cristo vence as espadas de Lucífer (a vã gula, a vã glória e a ambição), que, de joelhos em terra, Lhe oferece o mundo. $\mathrm{E}$ das sequências mais interessantes de todo o Poema, sendo, no final, Cristo laureado pelos esquadróes do firmamento pela sua vitória: “(...) Mostrando no valor ser sem seguido/Lhe mostrou num brevissimo momento/ Quantos Reinos se estendem pelo mundo/ E todo seu principio e fundamento/ De America que o valor tem tão jocundo/ Lhe fez mui sotilmente apontamento/ Do Peru, Tucumão, que a acompanha/ Brazil, Paragai e a nova espanha.// Poslhe tambem a vista o estandarte/ De Africa, q. do mapa tão lustroso/ He huma singular única parte/ Que mostra seu valor maravilhoso/ E o tropheo que nele se reparte/ Ethiopia, e o Congo magestuoso/ A cuja vista o preço seu não perde/ Manomotapa Angola e Cabo Verde.// Com o dedo the fez cosmografia/ De Azia nas potestates eminente/ Seos triumphos riqueza e valia/ O lustre de seus faustos excelente/ E vem grande aparato e bizarria/ Assi lhe debuxou mais sutilmente/ A provincia que leva, e que domina/ India, Arabia, magor, Japam e a China.// Ja a soberba europa a quem rodea/ Com suas salsas ondas o occeano/ $\mathrm{E}$ a quem ligando vai como em cadea/ $\mathrm{O}$ alto e largo mar mediterrano/ A Christo alli presente e encadea/ Pera ficar seu lustre mais ufano/ Italia com Pollonia, e Alemanha/ E com Hiberia, frança e a velha Espanha." (2, 84a $\left., 85^{\mathrm{a}}, 86^{\mathrm{a}}, 87^{\mathrm{a}}\right)$.

No Canto 3, de 102 estâncias (o quarto mais longo), são descritos os percursos de Cristo pela Palestina: “(...) Por toda a terra vay de Palestina/ Ajuntando as ovelhas derramadas/(...)" $(3,17 \mathrm{a})$.

No Canto 4, além da descrição de milagres de Cristo, é referido o mal da ociosidade, opondo-se ao bem que se alcança pelo trabalho. Neste contexto, destaca-se a pescaria infrutífera de Pedro e André; a manhã rompe, sendo a narração invadida pela força da aurora, tão natural quanto poética: “(...) Que à ora que as madeixas peregrinas/ da bella Aurora os Astros escurecem/ q. Aljofar vem vertendoo e perolas finas/ com q. as ligeiras nuvens enRiqueçem/ loguo este sol sahio co as divinas/ luzes selesteiais q. lhe pertencem/ Por q. seu esplendor inacesivel/ Pode somente a elle ser possivel." $(4,17 \mathrm{a})$ Pedro e André lançam de novo as redes, já desesperados por nada pescarem, quando a força divina intervém: “(...) O nova maravilha alto putento/ ó grandezas de Christo peregrinas/subidas sobre o humano entendimento/ singulares supremas e divinas/ pois tanto que as lançou no salço argento/ e tocarão nas aguas neptuninas/ abrio Thetis as liquidas moradas/ e as fes de seu thezouro carregadas.// Era hum assombro ver os nadadores/ sem sinal pelo mar caminho abrindo/ com fervido rumor e varias cores/ mais q. cristal e prata reluzindo/ huns piquenos e já outros maiores/ e os grandes e os miudos competindo/ todos juntos nas redes se metião/ com impeto tão grande que as rompião. // 
e pera ser mais claro he evidente/ o milagre q. toda a gente nota/ os pexes se sustinhão firmemente/ na Rede destroçada e toda rota/ nela estavão saltando alegremente/ admirando-se a gente q. devota/ pasma de ver que o $\mathrm{Ar}$ os sustentava/ assi na rede rota como estava" $\left(4,29^{\mathrm{a}}, 30^{\mathrm{a}}, 31^{\mathrm{a}}\right)$.

Passando para presença de Cristo em Jerusalém, e da prática da usura no Templo, a Autora remata a 62a oitava desta forma: “(....) e nem de Atalo o gosto nas comidas/ pode fartar a fome que tem Midas"(4, 62 $\left.{ }^{\mathrm{a}}\right)$. Este Canto 4 termina de forma idêntica aos anteriores, convidando, nos dois últimos versos, para o Canto seguinte: “(...) para longe caminha e entre tanto/ me quero preparar pera outro Canto."

No Canto 5 continuam os relatos de diversos milagres de Cristo, tema que se prolonga no Canto seguinte, sendo ainda aqui relatada a grande tempestade que os discípulos enfrentam, onde, além das forças da Natureza, entram Proteu, Neptuno e Tritão. Nereu é encarregado de chamar as Ninfas: “(...) Vinhaa Thetis Raynha nimpha rara/ Com a bella amphitrite q. esqueçida/ Do Amor q. lhe o Delphim solicitara/ Ho de Christo estava só rendida/ E Doris q. adoralo mais presara/ q. pessuir os bens todos da uida/ Orithia galharda a uem seguindo/ Com ella Deyopea competindo" (6, 57a).

O Canto 7 trata de episódios nos desertos da Galileia, onde, para a Autora, Cristo se defronta com as riquezas da prodigalidade - comparável ao sol, que nunca pára o seu curso - e da potência, multiplicando os peixes e o pão.

Os Cantos sucedem-se não variando a temática, numa escrita similar, que merece atento estudo, sendo as últimas quatro oitavas do Canto 13, e último da 2a Parte, Vida e Milagres de Cristo, como que uma súmula de todos os Cantos. A última é bem significativa, no sentido não só de traçar os objectivos da Autora enquanto escritora como enquanto religiosa, a imitação de Cristo : “(...) Permiti bom Jesus pois referida/ Deixo aqui voSa vida milagroza/ Que empregue de contino minha vida/ Em uoSa imitação tão gloriozal (...)” $(13,69$ a). O Canto termina com um desabafo da Autora, testemunho da sua confiança, traduzido na expressão: "Asim o pirmitira Elle".

A 3a Parte, Memorial da Paixão de Cristo e Triumpho do Divino Amor, apresenta manifestas diferenças nas grafias, sendo a inicial muito diversa e menos elaborada da que encontramos na $2^{\text {a }}$ Parte. No Canto 2, 28 a oitava, muda a grafia, para uma letra mais cuidada, clara e de mais fácil leitura, que prossegue durante todo este Canto e o seguinte, sendo que, no Canto 4, a grafia muda por duas vezes, terminando numa mais cuidada e elaborada, semelhante à $2^{\text {a }}$ Parte, e que se prolonga até final do poema.

Mantendo-se a estrutura dos Cantos, esta Parte segue uma clara influência bíblica na ordenação dos episódios, desde a chegada de Cristo a Jerusalém até à ressurreição, passando pelas descrições da Ultima Ceia e da Via Sacra. Trata-se de uma escrita muito emotiva, com grande carga de fé e devoção, onde o discurso místico pretende antes de tudo um contacto com o Divino. Das oitavas finais, destacamos: “(...) E vos deos de bomdade tão benigna/ que me fizestes ser tão venturosa/ que chegasse a trattar com pena indigna/ de vosa vida e morte glorioza (...)" $\left(11,76^{\mathrm{a}}\right)$. 
O Poema termina com um conjunto de seis versos, e não com uma oitava (esquema rimático $\mathrm{ABABAB}$ ) onde destacamos: “(...) O afecto meu dei que na alma cresse/ aseitai neste dom tão limitado/ (...)Senhor tratar de vos ningem merese/ que Deos so pode ser bem louvado.” $\left(11,78^{a}\right)$.

\section{Conclusão}

A formação das noviças nas comunidades, além da sua proveniência familiar e social, tinha importância fulcral na sua educação, daí que um dos ofícios de maior responsabilidade nas comunidades monásticas era o de Mestra das Noviças. A decisão acerca das leituras a serem feitas era de extrema importância. Ler com atenção e convicção era fundamental, numa altura em que cada vez mais se distinguia entre a oração mental e a oração vocal.

No que respeita à escrita, a sua expressão no mundo feminino é importante, porque rara. Da leitura à produção escrita continua a haver uma grande distância, e o claustro acaba por se tornar cada vez mais um espaço de libertação em relação ao mundo secular. Sem estarem sujeitas a tarefas domésticas, fazendo parte de uma comunidade internamente hierarquizada que libertava as religiosas do trabalho físico, num contexto contra-reformista, a escrita pode ser, além das descrições simples do espaço envolvente ou dos relatos místicos das fundadoras ${ }^{11}$, um meio de contacto com o Divino Esposo.

Para a região de Évora foram já estudados alguns exemplos ${ }^{12}$, sendo que em 1639 surgiu impressa parte da obra de Maria de Mesquita Pimentel, religiosa no mosteiro de S. Bento de Cástris. Restaram manuscritas duas partes, e foi delas que essencialmente tratámos, procurando que saíssem do anonimato, de molde a contribuir para a formação de uma ideia mais aproximada da efectiva produção literária feminina no período moderno em Portugal.

\section{Fontes}

Manuscritos B.P.E. (Biblioteca Pública de Évora)

Cód. CXXXI/2-2, F1.221

Cód. 66 Manizola, F1. 324.

Cód. 406 Manizola.

\section{Impressos B.P.E.}

S.N., E 24, C.1

11 M. da Rocha 1998: pp.239-250.
${ }_{12}$ I. Morujão 1995. 


\section{Bibliografia}

George Cardoso (1666), Agiologio Lusitano dos Sanctos, e Varoens Illustres em Virtude do Reino de Portugal e Suas Conquistas, Lisboa, Oficina de António Craesbeeck de Mello, Impressor de Sua Alteza, Tomo 3.

Diogo Barbosa Machado (1993), Biblioteca Lusitana Histórica, Crítica e Cronológica, 2. ${ }^{\mathrm{a}}$ ed., Lisboa, 4 Tomos.

Isabel Morujão (1995), Contributo para uma bibliografia cronológica da literatura monástica feminina portuguesa dos séculos XVII e XVIII. Lisboa, Universidade Católica Portuguesa, C.E.H.R.

(1998), "Literatura devota em Portugal no tempo dos Filipes: o Memorial da Infância de Cristo, de Soror Maria de Mesquita Pimentel", in Via Spiritus, n. ${ }^{\circ}$ 5. Porto, F.L.U.P.

P. António dos Reis (1745), Corpus illustrium poetarum Lusitanorum. Lisboa. Manuel Joaquim Moreira da Rocha (1998), “ Rainha Santa Mafalda: um modelo de perfeição. A construção da memória pelas monjas de Arouca no século XVII", in Actas do Colóquio Internacional Cister, Espaços, Territórios, Poder. Alcobaça, Vol. I. 239-250.

Innocencio Francisco da Silva (1862), Diccionario Bibliographico Portuguez. Lisboa, Imprensa Nacional-Casa da Moeda, Tomo 6. 141-143. 
(Página deixada propositadamente em branco) 


\title{
PAISAJE, CLIMA Y CARÁCTER EN DE HUMANA PHYSIOGNOMONIA DE GIOVAN BATTISTA DELLA PORTA
}

\author{
Miguel Ángel González Manjarrés \\ Universidad de Valladolid \\ miguelan@fyl.uva.es
}

\begin{abstract}
The De humana physiognomonia written by Giovan Battista della Porta (ca. 1535-1615) became the definitive physiognomical manual that compiled, on the one hand, all the already existing theories in the discipline from Pseudo-Aristotle in the $3^{\text {rd }}$ century bd. up to his period; and, on the other hand, the physiognomical doctrine of Hippocratic/Galenic roots. This work was first edited in 1586 in four books; it was extended into six books in 1601; finally, it was again extended and revised for its Italian version in 1610 . The former has two chapters (in addition to references disseminated throughout the writing) which narrate how the place where one lives and the dominant climate there determine or, at least, condition the human character. Our aim here is to appreciate Della Porta's elaboration of this topic and to analyse the literary structure that he uses for the writing.
\end{abstract}

Palabras clave: Della Porta, fisiognomía, medicina antigua, melancolía.

Palavras-chave: Della Porta, fisiognomonia, medicina antiga, melancolia.

1. La atención a la influencia del paisaje y el clima en el ser humano ha sido constante desde los tiempos remotos. Antes de incluirse en la tratadística fisiognómica, que arranca con la Fisiognomía del Pseudo-Aristóteles en el siglo III a.C., el tema en cuestión se trató ya con detalle en algunos textos del Corpus Hippocraticum, en especial Aires, aguas, lugares, así como en obras de historia y geografía, sobre todo en Heródoto. Ambas parcelas, medicina y geografía, habrían de ser las que aglutinasen los estudios etnográficos y antropológicos de la Antigüedad, con representantes tan destacados, en uno y otro ámbito, como Estrabón, Plinio, Galeno o Ptolomeo ${ }^{1}$. Sin que la medicina, al menos hasta después de época galénica, intercediese realmente en la fisiognomía, ya la codificación del Pseudo-Aristóteles establece, junto a los métodos zoológico y etológico, un tercer método fisiognómico de raíz etnográfica ${ }^{2}$. Con ello, y ya para toda la tradición fisiognómica antigua, medieval y renacentista, quedó

${ }^{1}$ Cf. M.M. Sassi 1988: 96-127; T.S. Barton 1994; B. Isaac 2004.

${ }^{2}$ Cf. Ps.-Aristóteles, Physiognomonica, 805a24ss (M.F. Ferrini 2007: 162-163; S. Vogt 1999: 296-298). Para los tres métodos, cf. A.M. Armstrong 1958. 
establecido un criterio de indagación humana, física y espiritual, cuyo punto de partida fue la necesaria interacción de hombre, tierra y cielo, los tres unidos por su misma constitución elemental.

Aunque en los tratados de fisiognomía, por lo común, la analogía zoológica prima sobre el método etnográfico, no faltan para éste alusiones y usos frecuentes desde la Antigüedad al Renacimiento ${ }^{3}$, como aquí trataremos de comprobar en el caso concreto del De humana physiognomonia de Giovan Battista della Porta (ca. 1535-1615). La gran obra compilatoria del autor napolitano asume, en efecto, la cuestión etnográfica. En su afán, ya viejo, por conceder a la fisiognomía estatuto científico, reconoce que sus métodos tradicionales habrían de reducirse a la cuestión humoral, de modo que sería la combinación de los humores la que de verdad determinase la constitución física y anímica del hombre, en virtud de la íntima relación entre cuerpo y alma. Pero la fisiología no lo sería todo, sino que habría determinados factores que influirían más o menos en su condicionamiento: dieta, astros, clima, ambiente, suelo, sexo, edad, etnia y otros varios. En definitiva, para conjeturar el carácter de una persona, habría que observar primero cómo el temperamento y el resto de factores aludidos habrían ido modelando sus rasgos físicos ${ }^{4}$.

Sea como fuere, las alusiones etnográficas en el De humana physiognomonia de Della Porta se escalonan en tres grandes niveles: explicación teórica; alusiones en descripciones fisiognómicas; uso de la materia para el tratamiento de las pasiones.

2. Las explicaciones teóricas del método etnográfico, cuyo origen atribuye Della Porta al romano Trogo Pompeyo, se ubican en los capítulos 12 y 13 del libro primero (16 y 17 de la versión italiana). Lo mismo que hace con los demás métodos, rechaza también éste por no demasiado fiable, pero decide dar información amplia al respecto según las fuentes antiguas más importantes:

At Trogus, qui ex variis caeli habitibus diversas morum coniectabat temperationes, iisdem argumentis afficietur quibus et ii qui ex digniorum animalium partibus et aspectibus animi facultates observabant. Nos ne fastidium potius quam novam doctrinam discentium animi pariamus, a praesenti orationis nexu dissita sit haec pragmatia. Sed de morum temperatura

${ }^{3}$ Cf. C.J. Glacken 1967.

4 "Questo temperamento fa differenti gl'Italiani dagli Spagnuoli, e i Spagnuoli da' Germani e Turchi; e finalmente questo aere, cielo, terra, cibo, acqua, età e tempo fanno il temperamento e i costumi; né solo in paese tanto lontano, ma ne' vicini ancora. Quanto sono differenti i costumi de' Napolitani da' Calabresi, e i Calabresi da' Pugliesi, e questi dagli Abbruzzesi?” (Della Porta 1988: 1,28, p. 103). Della Porta edita su obra en latín, en cuatro libros, en 1586; en 1601 (o 1599 por error de portada) publica una segunda edición latina ampliada a seis libros (reeditada al año siguiente), que sería la base de la versión italiana de 1610, con nuevos cambios y añadidos; tanto de la primera edición latina como de la versión italiana se hicieron numerosas reimpresiones a lo largo del siglo XVII. Aquí se cita por la edición latina en seis libros, salvo los añadidos de la versión de 1610, que van en italiano. Para Della Porta, cf. M. Torrini 1990; O. Trabucco 2003. 
corporumque formis ad varios caeli aspectus ecquid maiores nostri in medicina philosophiaque disgnissimi proceres perscripserint, futurum operaepretium arbitror si in medium exbibuero ${ }^{5}$.

El capítulo 12, pues, se destina a un repaso genérico de la influencia que sobre el hombre ejerce la zona y el clima en que se vive. Della Porta, para ello, recurre primero a los datos de Aires, aguas, lugares y los completa con otros procedentes de los Problemas de Pseudo-Aristóteles. El planteamiento inicial se estructura en tres grandes bloques, con dos zonas extremas y una templada: pueblos del Norte, es decir, de la zona fría del planeta, sin apenas variaciones estacionales; pueblos que viven donde hay fuertes y bruscos cambios de estación, en realidad de clima continental; pueblos que habitan en zonas de clima templado, con variaciones moderadas. Della Porta, en todo caso, rompe la simetría del texto hipocrático: si en éste hay una oposición general entre asiáticos y europeos, y después se establecen las diferencias pertinentes dentro de cada bloque, Della Porta, para el extremo norte, efectúa una síntesis de las cualidades que la obra hipocrática atribuía a los escitas ${ }^{6}$ y, para los pueblos continentales, echa mano de las explicaciones hipocráticas referidas de forma genérica a los europeos frente a los asiáticos ${ }^{7}$; las cualidades de la zona templada, en cambio, se toman de la parte en que la obra griega describe Asia Menor ${ }^{8}$. Se sigue, pues, la aplicación hipocrática de los temperamentos al clima ${ }^{9}$ : las zonas de clima invariable, donde siempre hace frío, condicionan el físico (cuerpos gruesos y flojos) y el carácter (pereza, escasa fuerza) del hombre; los lugares sometidos a mucha variación climática, en cambio, producen hombres fuertes, belicosos, aguerridos; el equilibrio estacional, como el humoral, da lugar a hombres templados, cuyo cuerpo y cuya alma se sitúan en el justo medio.

Tal esquema simple y abreviado se va después matizando con ejemplos concretos de pueblos muy diversos y según una sucesión casi cronológica de autoridades. Así, la lista de datos se sigue con Platón y su referencia al ideal climático de Grecia; continúa con los argumentos que al respecto ofrecen los astrólogos Ptolomeo y Fírmico Materno, en una primitiva enumeración de caracteres nacionales; añade el también esquema tripartito que se puede leer en Vitruvio, quien acerca ya la zona templada a Roma, causa de su universal poderío; por último, añade el testimonio de Plinio, que se mantiene en la misma tradición ${ }^{10}$. Para cerrar el capítulo, se deja un apartado dedicado a fuentes fisiognómicas, en este caso Adamancio y Pseudo-Polemón, cuya precaución respecto al método etnográfico se recoge como sigue:

${ }^{5}$ Della Porta 1602: 1,12, p. 28.

${ }^{6} \mathrm{Hp}$. Aër. 19-21, aunque también hay datos de 16 y 23 (gran parte de los pasajes hipocráticos citados en Della Porta se encuentran recogidos en Galeno, Quod animi mores corporis temperamenta sequantur, 8 [K. 4,4,798-803]). A ello se añade Arist. Pr. 14,1 y 15.

${ }^{7}$ Hp. Aër. 23. A ello añade datos de Arist. Pr. 14,4,8, 9,10,15 y 16.

${ }^{8} \mathrm{Hp}$. Aër. 12.

${ }_{9}^{9}$ Amplia explicación en J. Jouanna 2003: 54-71.

${ }^{10}$ P1. R. 435e-436a; Ptol. Tetr. 2,3; Firm. Mat. 1,2-4; Vitr. Arch. 6,1,3-4 y 9-11; Plin. Nat. 2,189-190. Similares citas en P. Magli 1995: 39-44. 
Sed cur in plurimis locis haec varia sunt, causa est quod alii alio tranferant sedes et confunduntur nationes, ut si Thraces navigaverint in Italiam et Itali in Thraciam, Persiae in Assyriam et Assyri in Persiam. Unde apud sapientes verissime illud habetur vulgo: locorum fortunas saepius, incolarum vero ingenia rarissime mutari ${ }^{11}$.

El capítulo 13 es ya un intento de pasar a explicaciones etnográficas más precisas. Se trata sólo de breves alusiones, que el propio Della Porta aconseja ampliar para un mayor conocimiento de su utilidad fisiognómica. El entramado de citas es aquí mucho mayor, aunque comienza con los datos que en la parte final de Aires, aguas, lugares se reservan a las distintas zonas del continente europeo: montañosas y escabrosas, hondas y pantanosas, elevadas y llanas, infértiles y secas, peladas y de clima extremo, fértiles y templadas ${ }^{12}$. Cada sitio, pues, confiere cualidades específicas a sus habitantes, si bien el aparente determinismo de clima y paisaje se considera sólo una influencia que puede superarse con la costumbre, la ley o, como había dicho antes, con cambiar el lugar de residencia. En todo caso, el resto del capítulo se emplea en ofrecer los rasgos tradicionales de los principales pueblos conocidos según diversas fuentes antiguas, citadas o no, en lo que constituye una amalgama demasiado embrollada de datos y opiniones. Se mencionan así a británicos, suecos y germanos; habitantes de las zonas del Tanaide, las lagunas Meótides y el Borístenes; saurómatas, hircanos y maságetas; tracios, hispanos, indios y persas; lusitanos, cántabros, irlandeses, corsos y ligures. Los datos vienen en su mayor parte de Estrabón y Mela, pero no faltan citas secundarias más raras y hasta poéticas: Arriano, Dionisio Periegeta, Ovidio, Lucano, Virgilio. Incluso hay algunos párrafos de contenido genérico más propios quizá del capítulo precedente, como la mención a Vegecio cuando recomienda para soldados a los habitantes del Norte, por ser más aguerridos que los sureños, o la referencia a Cicerón sobre las bondades del clima puro y despejado ${ }^{13}$.

En cualquier caso, Della Porta cierra su exposición con palabras de cautela acerca de la fiabilidad absoluta de los datos aducidos, pues que han de usarse más bien como referencia orientativa: sed quaecunque ex his superioribus retulimus ne putetis velim vera semper contingere, sed in pluribus ${ }^{14}$.

3. Tras las explicaciones teóricas, Della Porta recurre alguna vez a datos etnográficos para dar ejemplos de los significados fisiognómicos de las partes del cuerpo. Son más bien escasos, pero en general recogen alusiones ya hechas en el libro primero u otras de factura semejante. Hay, por ejemplo, nuevas referencias a Aires, aguas, lugares para ilustrar la cabeza alargada con una alusión a los pueblos del Norte o para explicar la gordura como consecuencia

${ }^{11}$ Della Porta 1602: 1,12, p. 30. Para Adamancio y Pseudo-Polemón, cf. R. Förster 1893: $1,382-383$ y 385.

${ }^{12}$ Hp. Aër. 24. Se añaden también referencias de Ar. Pr. 14,7, 38,4, 14,11-12.

${ }^{13}$ Veg. Mil., 2,1; Cic. Nat., 2,42.

${ }^{14}$ Della Porta 1602: 1,13, p. 32. 
de residir en tierras fértiles, húmedas y blandas ${ }^{15}$. Del mismo modo, se recurre a los germanos para ejemplificar la cabeza hundida en el occipucio (débiles y desmemoriados), a los genoveses, macrocéfalos y cilicios para la cabeza picuda (impúdicos y malvados), a los tracios para encarnar la estolidez o a los sicilianos como cantera de homosexuales ${ }^{16}$. Los ejemplos, en fin, podrían ampliarse en un sentido más genérico: se recurre a Vitruvio para explicar cómo los pueblos del ecuador tienen voz aguda (cobardes) o cómo el color muy oscuro de la piel, propio de egipcios y etíopes, es signo de extrema cobardía y astucia, para lo que se cita a Alberto Magno y Alejandro de Afrodisia ${ }^{17}$.

En definitiva, los datos etnográficos se emplean ahora como refuerzo de las propias teorías fisiognómicas: si los rasgos del cuerpo indican ciertas cualidades anímicas, a veces hay una causa geográfica y climática que condiciona el temperamento y, por tanto, influye de modo decisivo en el cuerpo y el alma del hombre. Una vez establecidas las correspondencias, sólo queda aplicar la analogía: por ejemplo, como las gentes del ecuador son negras, de voz aguda, cobardes y astutas, quienes sean de piel oscura y tengan voz aguda serán también cobardes y astutos.

4. El libro sexto de Della Porta, con referencia constante a Galeno, es un breve catálogo de variaciones afectivas, es decir, de información para aprender a mudar las pasiones y estados anímicos perjudiciales o insanos. Una vez conocido el carácter de una persona, y en caso de que esté dominado por malos afectos, habrá que aplicar los remedios necesarios para su enmienda. Pues que alma y cuerpo se influyen a la vez, tales remedios podrán ser de diferentes tipos: dietéticos, ambientales, geográficos, sociales o directamente medicinales. Respecto al caso que nos ocupa, las recomendaciones se fundan en el siguiente razonamiento: una vez que sabemos cómo influyen suelo y clima en el carácter humano, se trata de variar el lugar de residencia en función de las necesidades de cada sujeto.

Un buen ejemplo lo tenemos ya en el primer capítulo del citado libro sexto, en donde se trata de cómo volver prudente y sabio al ignorante. Junto a explicaciones naturales, Della Porta recurre a remedios dietéticos y medicinales, pero reserva una amplio espacio para cuestiones ambientales y climáticas, fundadas sobre todo en el Corpus Hippocraticum y en Galeno: para ser sabio hay que habitar en zonas de ambiente puro y seco, en tierras fértiles, húmedas y blandas, de clima ni frío ni cálido en exceso, sino convenientemente templado ${ }^{18}$.

El método, pues, consiste en aplicar a cada propósito los datos expuestos en los capítulos correspondientes del libro primero: si el frío extremo causa

15 Della Porta 1988: 2,1,6, pp. 121-122 (Hip. Aër. 14); Id. 1602: 4,2,1, p. 196 (Hip. Aër. 24)

${ }^{16}$ Della Porta 1602: 2,1,7, p. 54; Id. 1988: 2,1,16, p. 125 e Id. 1602: ibid., p. 57 (cf. Ath. Deipn. 11,60); Id. 1602: 5,6, p. 237; Id. 1988: 5,11,1, pp. 533-534.

${ }^{17}$ Della Porta 1602: 2,18,9, p. 106 (Vitr. Arch. 6,1,7-8); 4,3,3, p. 197 (Alberto Magno, De animalibus, 1,3,7; Alex. Aphr. Pr. 2,6).

${ }^{18}$ Della Porta 1602: 6,1, pp. 271-273. 
impotencia (así los escitas, como se explicaba en Aires, aguas, lugares), tal clima es bueno contra la intemperancia sexual; si las zonas pantanosas provocan somnolencia, resultan idóneas para los insomnes; si el clima invariable causa afeminamiento, para la virilidad es mejor vivir en ambientes continentales ${ }^{19}$. Los casos continúan de la misma forma con otras cualidades anímicas, repitiendo en gran medida los datos aportados en el libro primero: valientes y cobardes, afables y airados, robustos y débiles, agrestes y refinados, rapaces y ladrones, taimados, mentirosos, etc. En todo ello, pues, el clima y la región que se habite ejercen una influencia decisiva y, por tanto, prestan gran ayuda para enmendar los vicios y fomentar las virtudes, objetivo último del tratado.

5. En definitiva, y aunque Della Porta juzga que la causa principal que determina el carácter de una persona es su temperamento, es decir, sus cualidades fisiológicas, remite también a otros condicionantes de la tradición fisiognómica y, entre ellos, al etnográfico y climático. Su exposición teórica es una simple amalgama de fuentes antiguas, pero su mayor aportación estriba en el uso que de ellas hace después para ejemplificar el valor fisiognómico de las partes del cuerpo y sobre todo para emplearlas como remedio psíquico. El paisaje y el clima, además de ofrecer cierta orientación para conjeturar el carácter de un hombre, sirven también para sanar sus desequilibrios anímicos.

\section{Bibliografía}

A. M. Armstrong (1958), “The Methods of the Greek Physiognomists”, Greece and Rome 5.1, 52-56.

T. S. Barton (1994), Power and Knowledge. Astrology, Physiognomics and Medicin under the Roman Empire. Ann Arbor.

G. B. Della Porta (1602), De humana physiognomonia. Nápoles.

G. B. Della Porta (1988), Della fisonomia dell'uomo, M. Cicognani (ed.). Parma.

M. F. Ferrini (ed.) (2007), Aristotele, Fisiognomica. Milán.

R. Förster (1893), Scriptores physiognomonici Graeci et Latini, 2 vols. Leipzig.

C. J. Glacken (1967), Traces on the rodian Shore: Nature and Culture in Western Thought from Ancient Times to the End of the Eighteenth Century. Berkeley.

B. Isaac (2004), The Invention of Racism in Classical Antiquity. Princeton.

J. Jouanna (ed.) (2003), Hipocrate, Airs-Eaux-Lieux. París.

P. Magli (1995), Il volto e l’anima. Fisiognomica e passioni. Milán.

L. Muraro (1978), Giovanni Battista Della Porta, mago e scienziato. Milán.

M. M. Sassi (1988), La scienza dell'uomo nella Grecia antica. Turín.

M. Torrini (ed.) (1990), Giovanni Battista della Porta nell'Europa del suo tempo. Nápoles.

${ }^{19}$ Della Porta 1602: 6,7,9 y 10, pp. 278-183. 
Paisaje, Clima y CARÁcter en De humana Physiognomonia

de Giovan Battista della Porta

O. Trabucco (2003), "Il corpus fisiognomico dellaportiano tra censura e autocensura", Rinascimento 43 569-599.

S. Vogt (ed.) (1999), ed., Aristoteles. Physiognomonica. Berlín. 
(Página deixada propositadamente em branco) 


\title{
ESPAÇOS PARA O DEVER E O LAZER NUM MODELO DE EDUCAÇÃO HUMANÍSTICA (1599)
}

\author{
Margarida Miranda \\ Universidade de Coimbra
}

\begin{abstract}
Drawing upon the Ratio Studiorum of the Society of Jesus, recently published in a brand new Portuguese version, the original version (1599) of which embodies the guidelines for the studies at the Jesuit high schools, in Europe and throughout the world, this essay highlights some features of the academic regulations, and it focuses in particular on the most innovative ones as well as on those that most clearly draw inspiration from Greek-roman social models.
\end{abstract}

Keywords: colleges, education, history of Jesuits, Humanism, ratio studiorum.

Palavras-chave: colégios, educação, História dos Jesuítas, Humanismo, Ratio Studiorum.

A Ratio Studiorum dos colégios da Companhia de Jesus foi elaborada ao longo de várias décadas, até tomar forma definitiva em 1599, com a promulgação de um amplo conjunto de regras que se enviou a todas as províncias, após sucessivos aperfeiçoamentos resultantes das primeiras aplicações no terreno. ${ }^{1}$

Tendo em conta a importância destes colégios na educação da Europa - quando praticamente não havia outras respostas à procura crescente de escolarização por parte das populações, quando a procura escolar se generalizara e sofrera uma forte aceleração, (ou não estivéssemos nós no século da revolução da imprensa) - tendo em conta também o carácter fundador deste documento sobre outras instituições escolares que nasceram à sua imagem, o que procurarei fazer no escasso tempo da minha intervenção será descrever alguns aspectos da organização escolar daqueles mestres e alunos, especialmente alguns aspectos mais inovadores e mais visivelmente inspirados em modelos sociais de matriz greco-romana. É pois do espaço social e não do espaço físico que vos irei falar.

\section{O rector}

A presidir à instituição escolar jesuítica encontrava-se um reitor, e não um principal, como acontecia noutros estabelecimentos escolares da época (em Alcalá, Salamanca, Paris ou Coimbra). Em latim clássico, o termo rector

\footnotetext{
${ }^{1}$ Ratio Studiorum da Companbia de Jesus (1599). Regime escolar e curriculum de estudos. Edição bilingue latim-português. Introdução, versão e notas por Margarida Miranda; Ratio Studiorum, um modelo pedagógico por José Manuel Martins Lopes S.J. Edições Alcalá 2008; doravante simplesmente Ratio.
} 
designava justamente 'aquele que governa'. Aplicava-se especialmente ao 'capitão de um navio', mas designava também aquele que estava à frente de um grupo de jovens, com uma função educativa. Essa é sem dúvida a explicação para a escolha deste termo na Ratio, em detrimento das outras designações correntes - além de ser também esta a designação da autoridade máxima na Universidade de Paris, modelo pedagógico da Ratio.

\section{As classes}

Também ao modo de Paris, os estudantes estavam cuidadosamente distribuídos por classes, de acordo com o seu grau de aprendizagem. A aplicação do termo classe (classis) para designar um grupo de alunos de idades próximas entre si, com o mesmo grau de instrução, a quem se oferece um tipo de programa adequado ao seu nível de aprendizagem, é evidentemente uma herança da pedagogia parisiense que passou a estruturar toda a rede escolar jesuítica - embora não tenha sido Paris a criar este sistema, mas sim os frades jeronimitas, conhecidos como Irmãos da Vida Comum.

Devemos, aliás, precisar que o termo classis não é uma invenção do século XVI, mas simplesmente a redescoberta de um termo já usado por Quintiliano, ao descrever as escolas de retórica do seu tempo (Institutiones Oratoriae, 1,2.23, por exemplo). Não significa isto porém que, até ao século XVI, não encontremos uma separação efectiva entre os cursos frequentados por gramáticos ou por teólogos. Ou que, no interior de uma disciplina, os alunos não se encontrassem mais ou menos agrupados de acordo com o programa que seguiam. Contudo, é no século XVI que a prática das classes corresponde a uma mais nítida separação sequencial de saberes, por níveis sucessivos de complexidade, gradualmente repartidos em função da idade e dos conhecimentos adquiridos. O sistema de classes era a solução para a qual o método parisiense apontava mais naturalmente. ${ }^{2} \mathrm{O}$ esforço de racionalização do ensino, a que a nova Ordem de religiosos se viu obrigada, não podia senão conduzir à adopção do mesmo sistema, devido, por um lado, à concentração crescente do ensino nos colégios e, por outro, à necessidade evidente de repartição quer dos alunos quer das tarefas, antes confiadas a um só mestre. Foi, pois, assim que teve início um aspecto que hoje nos poderia parecer tão antigo como a educação: a ordenação sequencial dos alunos e das matérias; o ensino por níveis, a construção de fundamentos sólidos antes de passar ao nível seguinte e consequentemente a existência de uma ordem numérica entre alunos e entre programas.

\footnotetext{
${ }^{2}$ Segundo Gabriel Codina-Mir (1968: 101 ss.), a mais antiga referência seiscentista ao sistema de ordenação sequencial de matérias por graus sucessivos de complexidade encontra-se no programa de Montaigu de 1509. Em meados do século XVI (1538 e 1540), ainda são numerosos os testemunhos de professores que se queixam dos mestres do seu tempo, que ensinavam os rudimentos de latim indistintamente com os oradores, os poetas, as Tusculanas de Cícero, a sintaxe dos verbos e os filósofos. Ao organizar o colégio de Nîmes (1540), Claude Baduel mostra ter consciência de instaurar um sistema novo, cuja novidade contrastava com a prática tradicional do ensino das letras.
} 
Para o estudo das letras e humanidades previa a Ratio Studiorum cinco classes: três de gramática, uma de humanidades e uma de retórica, cada uma das quais obedecia à precedência da anterior e ao cumprimento de um programa.

\section{As letras pagãs}

Antes da experiência em Paris, os mestres jesuítas tinham conhecido o colégio trilingue de Alcalá, que foi (juntamente com o colégio de Leão $\mathrm{X}$ em Roma e o colégio trilingue de Lovaina) um dos modelos inspiradores do próprio colégio Real de Francisco I de França. Os colégios dos Jesuítas tornavam-se pois colégios trilingues, para o ensino do latim, do grego e do hebraico. Com uma diferença porém: enquanto o colégio trilingue de Alcalá e os colégios trilingues protestantes nasceram e viveram em função do estudo e da interpretação da Sagrada Escritura, os colégios dos jesuítas não descuraram as letras pagãs e fizeram delas um instrumento indispensável para a eloquência sagrada - como se verifica pela preponderância da prosa e dos autores clássicos (mais do que cristãos) no programa humanístico, sobretudo na retórica.

\section{O uso do latim}

Embora trilingues, nestes colégios, a língua privilegiada era, como sabemos, o latim (Ratio,II, 8 e18). Com algumas excepções concedidas aos estudantes no dia de pausa semanal, ou nos momentos de recreio - e mesmo essas dependiam do juízo do reitor - a língua de comunicação no colégio, na sala de aula ou no refeitório, para alunos internos ou externos, era necessariamente o latim.

A recomendação era extensiva aos professores: em tudo quanto se refere às aulas não se permita nunca o uso da lingua materna. Serão desclassificados os alunos que descurarem esta norma. Por isso, o professor falará sempre em latim... (Ratio, $\mathrm{xv}, 18)$

$\mathrm{Na}$ prática, porém, sabemos que a realidade não era esta. Eram diversas as circunstâncias em que a própria Ratio recomendava ao professor o uso da língua materna, tendo em vista a compreensão dos alunos e o interesse da matéria, desde que o fizesse com dignidade e elegância, recomendava a Ratio (xviI, 5 por exemplo).

\section{As Academias}

Cientes da importância de que se revestia a formação literária, num curriculum de estudos universalmente orientado para a eloquência e a comunicação, e conscientes da inovação que aquele reforço representava no curriculum de estudos tradicional, a Ratio recomendava que, para as letras, fossem preparados professores de excelência. Cada provincial tinha a responsabilidade de assegurar uma espécie de viveiro (seges) de onde saísse uma estirpe permanente de bons professores (I, 22). Nas regras para o provincial, é evidente a preocupação pela escolha e a formação qualificada dos mestres. A inclinação para as letras e o respectivo ensino podia mesmo constituir um dos critérios para admitir os candidatos à Companhia (I, 25, 26). 
Por isso, apesar da escassez de mão-de-obra para sustentar os colégios, o professor não iniciava o seu magistério sem primeiro exercitar o ensino num lugar próprio para o efeito, o qual recebia a designação de Academia (I, 30).

Tendo surgido primeiramente em Itália e depois nas outras cidades da Europa, no Renascimento, as academias eram instituições estruturadas, com leis e estatutos próprios, destinadas ao estudo e à prática desinteressada das letras, das artes e das ciências, que tomavam o nome da primeira instituição platónica. Tal como essas primeiras academias modernas, as academias nascidas nos colégios tinham um carácter marcadamente humanístico. Reuniam os melhores alunos para o cultivo desinteressado das artes e das letras, em ambiente de lazer marcadamente humanístico, de estímulo ao pensamento, ao saber e à criação artística

Semelhantes às academias de gramáticos, de humanistas, de retóricos, de filósofos e de teólogos com que os diversos estudantes do colégio aperfeiçoavam a sua actividade artística e intelectual, as academiae ad magistros intituendos foram certamente o primeiro modelo que a idade moderna conheceu de uma escola específica para a formação professores. A herança reportava-se à escola platónica de Atenas, com que o próprio Cícero se identificava e que, através do neoplatonismo, tanto influenciara a transmissão do pensamento grego à Europa do Renascimento.

\section{As bibliotecas}

Outra marca evidente do cultivo desinteressado do saber é a importância das bibliotecas. Para satisfazer as novas exigências criadas com a descoberta da tipografia, os colégios viam-se também forçados a desenvolver novas técnicas de leitura e divulgação dos textos, a imprimir a sua própria produção para uso de alunos e professores e a organizar as suas próprias colecções de livros. Também esse era um ofício do Provincial: aplicar uma verba anual para o crescimento da biblioteca (proveniente dos bens do próprio colégio, ou de qualquer outra fonte), a fim de que todos dispusessem de uma quantidade razoável de livros - verba essa que por motivo algum seria desviada para outros fins (I, 33). Ofício do prefeito de estudos era assegurar os livros necessários para cada classe, lembrando ao reitor a necessidade de possuir livros em grande quantidade (III, 29) e, sobretudo, tomando junto dos livreiros da cidade, as precauções necessárias para a provisão regular de livros (XII, 28).

\section{As decúrias e os decuriões}

A organização e disciplina do colégio não se baseava apenas na divisão por classes. Cada classe era dividida em grupos de cerca de dez alunos - a decúria - à qual presidia o decurião (Ratio xv, 19 e 36) ${ }^{3}$. A divisão dos alunos

\footnotetext{
${ }^{3}$ A referência mais remota à prática das decúrias nos colégios da Companhia é uma carta de Cipriano Soares, de 1553, sobre o Colégio de Santo Antão: omnes in certos ordines sunt distributi,
} 
em decúrias (termo que se inspirava na divisão decimal do exército romano) era um antigo hábito monástico ${ }^{4}$ característico sobretudo dos Irmãos da Vida Comum (como, aliás, muitos outros aspectos da pedagogia destes mestres) e também conhecido do modus parisiensis. Designado por este ou por outro termo, o costume destinava-se a tornar mais consistente a organização e o governo de um grande número de estudantes, mas acima de tudo permitia fomentar o ensino mútuo entre companheiros e passar da emulação individual para uma emulação colectiva. Entre cada decúria da classe realizava-se pois uma emulação constante, por meio de competições poéticas e todo o género de disputas literárias (concertationes) que transpunham para o estudo das letras a prática escolástica da disputa e do debate permanente.

Cada decúria assumia, portanto, uma designação própria, tirada do imaginário clássico ('Romanos contra Cartagineses', por exemplo, ou então, em certos casos de imaginário mais contemporâneo, 'Turcos contra Cristãos'). Uns e outros rivalizavam não já pela espada mas pela toga, isto é, pelas litterae bumaniores.

\section{As magistraturas romanas}

Um momento alto da vida escolar de cada classe era a eleição dos cargos ou magistraturas dentro de cada decúria. Periodicamente (todos os meses ou em meses alternados), os alunos eram sujeitos a um concurso literário. Aqueles que participavam recebiam um título honorífico mais ou menos elevado consoante os méritos da sua composição.

Aqueles que escreverem melhor obterão a magistratura superior; os que se lhes seguirem receberão, por ordem decrescente, outros títulos honoríficos, cujos nomes se hão-de tirar dos cargos civis e militares gregos e romanos ...

Em regra, cada decúria tinha assim as suas próprias magistraturas e a outra os respectivos adversários, de modo que cada aluno tivesse o seu adversário correspondente. As magistraturas mais elevadas de cada uma das partes recebiam os primeiros lugares na sala de aula $(\mathrm{xv}, 35)$.

O clima de competição que se deixa adivinhar por detrás de todas estas práticas pode admirar-nos, mas se tivermos em conta a sociedade fortemente hierarquizada dos séculos XVI, XVII e XVIII, não pode deixar de nos surpreender

quos decurias, quod decem fere habeant discipulos, vocamus. Inter hos est unus qui omnium decuriarum in suo gymnasio curam habet; cuique etiam decuriae suus praeest decurio. Sic nullo labore intelligitur si quis absit, si parum in audiendo attentus, si negligens in memoria exercenda sit. Haec res maiorem nostra opinione in dies ostendit commoditatem ad multitudinem gubernandam. Sunt autem positi in decuriis pro uniuscuiusque profectu. (Litterae Quadrimestres, vol. 2, 219).

${ }^{4}$ Embora com terminologia diferente, as regras monásticas criavam as decaniae, chefiadas pelos decani, que auxiliavam o Abade no governo do mosteiro. O princípio é conhecido nas regras de S. Bento, de S. Frutuoso de Braga e de Santo Isidoro. 
que os méritos escolares acabassem por derrubar o próprio critério do nascimento social, que presidia à disposição dos alunos na sala de aula, como se vê em XII, 29.

Com este costume simultaneamente pedagógico e disciplinar, os novos questores, pretores e cônsules das cidades europeias, os novos generais, centurióes e legionários eram agora gramáticos e humanistas; pertenciam às classes dos colégios dos jesuítas e distinguiam-se não pelas vitórias políticas e militares, mas pelas vitórias poético-literárias que preenchiam o tempo de lazer na escola.

Um dos 'cargos' da classe gozava, porém, de carácter mais permanente, pois era designado pelo prefeito de estudos: em cada classe havia um censor público, que também podia ser chamado decurião máximo ou pretor ${ }^{5}$. Tal como o censor romano, o censor da classe tinha o dever de olhar pelos costumes (a cura morum), especialmente os costumes mais ligados ao estudo, e comunicar ao professor as faltas ou omissões de cada um no trabalho e na disciplina escolar. Mediante aprovação do professor, o decurião máximo tinha o direito de interceder pelos seus companheiros nas penas menores, mas essas (as penas) eram sempre aplicadas por um terceiro - o Corrector, ou Executor, já que os jesuítas estavam formalmente proibidos de castigar pessoalmente aos seus alunos. ${ }^{6}$

Sobre os castigos, aliás, a Ratio recomendava uma atitude de condescendência (Ratio XV, 40):

Não seja o professor demasiado propenso a castigar os seus alunos, nem demasiado solícito a buscar-lhes as faltas. Mais vale fechar os olhos, se o puder fazer sem prejuizo de ninguém. Não castigue ninguém fisicamente com as suas próprias mãos (pois essa é a função do executor) e abstenha-se em absoluto de lhes fazer qualquer ofensa, por palavras ou por obras. Não chame

${ }^{5} \mathrm{O}$ ofício de censor estava previsto nos estatutos da Universidade de Paris, no Ginásio de J. Sturm, de Estrasburgo, e na prática da maioria dos colégios europeus.

${ }^{6}$ Ratio, XII, 38: Para aqueles que cometerem alguma falta na aplicação ao estudo e nos bons costumes, e para quem as palavras e exortações não bastarem, o prefeito designará um executor que não pertença à Companhia. Onde não se puder ter um executor, procurar-se-á outro modo de os castigar, ou por intermédio de algum dos escolásticos ou por qualquer outro meio conveniente. Mas não se castiguem em classe as faltas cometidas em casa, a não ser por motivo grave e muito raro.

Os castigos corporais, alguns de extrema severidade, eram uma prática corrente em todas as instituições escolares, independentemente da idade do estudante. O próprio Santo Inácio de Loyola, com mais de trinta anos, escapou a uma destas punições que lhe queria administrar o Principal de Santa Bárbara, Gouveia, o velho, por achar que ele perturbava a disciplina do Colégio. Os jesuítas, porém, optaram por uma solução original (Monumenta Paedagogica, vol.1, 423424). Ao criarem, em 1551, no Colégio Romano, o cargo de executor (corrector), já ensaiado em Messina em 1549, os Jesuítas introduziram uma novidade: um leigo de fora, imparcial e neutro, de idade adulta, com estudos avançados, homem sério e piedoso que, mediante um salário honesto, executava, sem preconceitos, as sentenças ditadas aos culpados - poupando aos religiosos a imodéstia daquele acto e aos professores o odioso da função. O mesmo cargo, no entanto, já havia sido introduzido, por diferentes razões, por Jean de Standonk, em 1499, no colégio de Montaigu, célebre pela severidade da sua disciplina. 
ninguém a não ser pelo seu nome ou apelido (...).

A todos os professores a Ratio afirmava ainda algo da mais evidente modernidade: é mais fácil obter a disciplina com a esperança num honra ou numa recompensa (e com o receio da desonra) do que por meio dos castigos corporais (xv, 39).

\section{O festival literário}

Para multiplicar as recompensas não faltavam expedientes.A afixação pública das melhores poesias nos dias de festa, as declamações solenes nas ocasiões mais importantes, a atribuição dos principais papéis nas representações teatrais eram, a um só tempo, exercício literário e ocasião de verdadeiro prazer lúdico a que aspiravam as ambições de qualquer aluno. As representações dramáticas de grande aparato, que reuniam milhares de espectadores de toda a cidade, procuravam fazer de cada actor o grande orador cristão modelado por Cícero, mas também por Róscio e por Séneca.

A ocasião mais esperada em todo o ano era, contudo, a entrega pública dos prémios alcançados no festival literário, um concurso aberto a todas as classes do colégio e sujeito a um regulamento específico ${ }^{7}$. O capítulo xIV da Ratio descreve todas as normas que definiam aquelas 'Olimpíadas' literárias: as diversas provas do concurso para as diversas modalidades literárias (prosa latina e grega e poesia latina e grega); o número de prémios a atribuir; o tempo para a realização das provas; o modo de entrega das composições sob rigoroso anonimato; a composição do júri e os critérios de avaliação e, finalmente, a cerimónia pública de entrega dos prémios aos vencedores, com a maior solenidade, diante do maior número possível de pessoas, no meio de música e de novas declamações poéticas.

Como outrora com os vencedores olímpicos, a celebração dos oradores e poetas premiados, cobertos de glória, reconhecidos pelos da sua classe e pelos seus rivais, era ocasião para novas composições poéticas e musicais, por vezes encomendadas a músicos profissionais (como em Coimbra, Lisboa e Evora). O momento era de exaltação e de júbilo. Se durante todo o ano o estudante vivia quotidianamente o jogo da emulação de forma bastante cénico-dramática, naquele momento o jogo atingia o cume da escalada, e o aluno tornava-se o vencedor não da sua decúria nem da sua classe, mas de todo o colégio. Era o espírito agónico grego, não já incarnado na actividade militar - como no imaginário homérico -, não já plasmado pela competição física dos melhores dos atletas - como no tempo de Píndaro e dos Jogos Pan-helénicos -, mas pela competição poética e intelectual da vida académica - como o próprio Xenófanes teria estimado para o seu tempo.

\footnotetext{
${ }^{7}$ Além dos prémios públicos, cuja cerimónia era da responsabilidade do reitor e do prefeito, a Ratio recomendava ainda prémios privados, em cada classe, ainda que simbólicos (XII, 35 e 36).
} 


\section{O festival dramático}

Por último, se no costume dos prémios literários reconhecemos o capital simbólico das Olimpíadas helénicas, fácil é reconhecer nas tragédias e comédias do colégio, o arquétipo de um outro festival grego: o festival dramático.

Sobre este, a Ratio é muito parca em palavras (as tragédias e comédias deverão ser de tema sacro e piedoso, em latim e muito raras... Ratio, II, 13) mas a história mostrou que enquanto a Ratio se ocupava em abrandar o entusiasmo de alunos e professores por esta forma dispendiosa de representação, os colégios continuavam a distinguir-se pelos grandes espectáculos com que deslumbravam a sociedade. Unos dizian que en medio de Grecia no se pudiera representar mejor, escrevia uma testemunha ao descrever o espectáculo dado em Coimbra, em 1559.

Para uma representação em Julho, já o professor de humanidades ou de retórica teria distribuído há muito os papéis entre os alunos. Quanto aos ensaios, podiam começar em Janeiro ou Fevereiro. Envolviam toda a classe mas também músicos e cantores profissionais chamados de fora, bem como aqueles que cooperavam na construção de cenários requintados e na recolha de vestes sumptuosas e acessórios de aparato, com a colaboração entusiástica da fidalguia da cidade.

Festivais dramáticos, que envolviam todo o colégio, concursos de prosa e de poesia, o uso permanente da língua latina, a organização em classes e em decúrias, um imaginário de magistraturas romanas civis e militares, o fenómeno das bibliotecas e das academias para o estudo sistemático das letras pagãs, e a imitação explícita de Cícero, inscreviam-se num tradição escolar que nunca rompera, afinal, com a memória do triuium e do quadriuium. O capital simbólico greco-romano presidia ao programa de estudos humanísticos proposto pela Ratio e actuava vivamente nas práticas escolares quotidianas dos colégios, modelando o espaço do dever e do lazer de muitas gerações de estudantes.

\section{Bibliografia}

[Litterae Quadrimestres] Monumenta Historica Societatis Iesu, Litterae Quadrimestres. Madrid-Roma, vol. 1-7, 1894-1932.

[Monumenta Paedagogica] Monumenta Historica Societatis Iesu, Monumenta Paedagogica Societatis Iesu, vol. 1-5. Roma, 1965-1986.

Gabriel Codina-Mir (1968), Aux sources de la pédagogie des Jésuites. Le modus parisiensis. Roma, Institutum Historicum Societatis Iesu.

Ratio Studiorum da Companbia de Jesus (1599). Regime escolar e curriculum de estudos. (2008) Edição bilingue latim-português. Introdução, versão e notas por Margarida Miranda; Ratio Studiorum, um modelo pedagógico por José Manuel Martins Lopes S.J.. Edições Alcalá 2008. 


\title{
UTOPÍA, ESPACIOS SOÑADOS Y MITO CLÁSICO EN LA TRAGICOMEDIA DE LOS JARDINES Y LOS CAMPOS SABEOS DE FELICIANA ENRÍQUEZ DE GUZMÁN
}

\author{
Cristina de la Rosa Cubo \\ Universidad de Valladolid
}

\begin{abstract}
The Spanish playwright, Feliciana Enríquez de Guzmán, devoted many years of her life to the composition of a tragicomedy where she defines herself as a defender of the precepts of Greco.Latin theatre. The play takes place in a legendary time where men coexist with the ancient Gods and is used by the author as a reflection of a dream reality, which provides answers to her worries and releases her true ambitions and vital expectations. In the play, the author presents the understanding father and own free will which she never had and the transgression capacity that the society always denied. Thus, the tragicomic world which so well describes the society, the culture and the politics of her days, turns frequently into a distorted image of the daily atmosphere in the Spanish XVII century, by offering an irreverent and amusing view of the classical myth.
\end{abstract}

Keywords: classical myth, Feliciana Enríquez de Guzmán, garden, locus amoenus, transgression, woman.

Palavras-chave: Feliciana Enríquez de Guzmán, jardim, locus amoenus, mito clássico, mulher, transgressão.

Feliciana Enríquez de Guzmán ${ }^{1}$ termina su obra "la Tragicomedia de los Jardines y los Campos Sabeos" en $1519^{2}$. El lugar elegido por Feliciana para enmarcar la ficción literaria de su única obra es un jardín de gran valor simbólico como veremos. El jardín en el teatro barroco se ha estudiado como elemento esencial del espacio escénico en el teatro cortesano ${ }^{3}$, un espacio en el que se desarrolla la puesta en escena de la obra teatral, que sigue las convenciones de la época y que tiene una innegable relación con el texto dramático ${ }^{4}$.

${ }^{1}$ En anteriores ocasiones he abordado el estudio del mundo clásico en la obra de Feliciana: C. de la Rosa Cubo (2005). P. Conde Parrado, C. de la Rosa (2005).

${ }^{2}$ Feliciana Enríquez de Guzmán escribió bajo el título de La Tragicomedia de los Jardines y los Campos Sabeos dos tragicomedias en verso de cinco actos cada una con coros y entreactos. Una fiesta teatral de la que no ha existido una edición moderna y completa hasta la aparición de la obra de Louis Pérez en La tragicomedia de los jardines y los Campos Sabeos: L. Pérez 1988. Es la edición que seguimos en nuestras citas.

${ }^{3}$ T. Ferrer Valls 1991.

${ }^{4}$ O. Arróniz 1977. J. M. Díez Borque 1991. A. Egido 1989. J. De Lara Garrido, 1995. 
Por supuesto, también debemos relacionar las continuas alusiones al motivo del jardín con el tópico del locus a moenus ${ }^{5}$, acuñado por la antigüedad grecolatina y presente en todas las épocas literarias. Recordemos que el locus amoenus parte del escenario de la poesía bucólica de tema amoroso e idílico. Como señaló Robert Curtius ${ }^{6}$, el paisaje ameno suele penetrar asimismo en la descripción poética de los jardines: "El locus amoenus es un paraje hermoso y umbrío, sus elementos esenciales son un árbol (o varios), un prado y una fuente o arroyo; a ellos pueden añadirse un canto de aves, unas flores y, aún más, el soplo de la

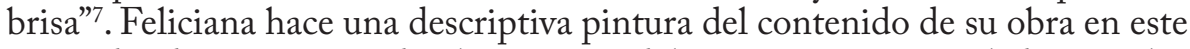
texto, donde aparecen todos los tópicos del locus amoenus mezclados con los elementos característicos del amor caballeresco:

Jardines, huertas, campos, bosques, ríos;

Sueños, máscaras, letras, cartas, joyas;

Afectos amorosos, castos, puros;

Flores, donayres, danças, bailes, músicas;

Torneos, luchas, coros desposorios (...)(Pérez 45)

Unos jardines que se alejan del tópico del hortus conclusus, pues una de sus características, que se describe en los primeros versos del acto primero, es la ausencia de muros y puertas, en clara alusión a la libertad de los personajes que en ellos moran:

\author{
De un agravio acerbo, $y$ duro \\ estos jardines se quexan: \\ que sin defensa los dexan \\ de cerca, torres y muro. \\ campos, valles, bosques, prados \\ rio, jardines y huertas \\ todo está junto sin puertas \\ sin paredes ni vallados. (Pérez 46)
}

La inmovilidad y perfección vegetal remite a un espacio único donde el tiempo no transcurre. Los jardines descritos están fuera del tiempo real, como si se tratase de un jardín ficticio que se viese en una esfera de cristal, pues, por definición, los jardines se oponen a la naturaleza por el hecho de detener el tiempo con una vegetación siempre viva, a la que no afecta el paso de las estaciones porque su vegetación posee una frescura perenne ${ }^{8}$ Feliciana Enríquez, manteniendo la unidad de lugar del teatro clásico, sitúa los 5 actos de cada una de las partes de su tragicomedia en los míticos Jardines de Saba, así lo afirma en el prólogo?:

${ }^{5}$ C. Hernández Varcárcel 1984.

${ }^{6}$ Cf E. R.Curtius 1977: 280-282

${ }^{7}$ Ibid. p. 280

${ }^{8}$ A. Egido 1990: 116.

${ }^{9}$ Feliciana sigue las leyes dramáticas del Arte clásico grecolatino, manteniendo la estructura 378 


\title{
Si estos preceptos con rigor guardados, \\ Yo, señores os diesse dos comedias (...) \\ $Y$ en todas ellas siempre un mismo sitio, \\ Siempre un mismo lugar, en los Jardines, \\ En la primera parte en toda ella. \\ Y en la segunda por la propia forma \\ En los campos Sabéos observasse? (Pérez 45)
}

Si es común como hemos dicho, la aparición del jardín en el teatro barroco, no lo es tanto que se precise su situación geográfica, la fértil región de Saba, en lo que, por aquel entonces, se conoce como la Arabia Felix. Tanto Saba ${ }^{10}$ como el adjetivo sabeo es referencia corriente en la literatura de la época ${ }^{11}$, evoca un lugar lejano, y hace referencia a su mítica reina y al incienso que allí se produce. Feliciana no explica la razón que le lleva a localizar su obra en este espacio concreto, una explicación podría ser la semejanza fonética de Sevilla-Saba, pues ella declara en uno de sus prólogos que los hechos narrados en Arabia, han sucedido realmente en Sevilla:

\author{
De dos amantes que en sus tiernos años \\ Se amaron y adoraron con invidia, \\ $Y$ emulación de muchos enemigos, \\ Desde el primero instante, en que se vieron, \\ $Y$ en el mismo en sus almas dulcemente \\ Con reciproco amor se transformaron; \\ Aunque ella se mudó, y a el que fue firme, \\ Remuneró el muy Alto con ventajas; \\ La bistoria en nuestros tiempos sucedida, \\ Que vio el famoso Betis y otro río, \\ $Y$ hoy leen escrita por sus verdes álamos; \\ Cifra nuestra Poeta Sevillana \\ En su Tragicomedia, que en Arabia, \\ Finge haber sucedido en los Sabeos, \\ Campos, y sus jardines, que gozaron \\ Los Amores de Venus, y su Adonis. ( Pérez 42-43)
}

Claramente vemos en las palabras de Feliciana que sus intenciones son dejar constancia de sucesos autobiográficos amparada en la farsa teatral, y, efectivamente, en la Tragicomedia el hilo conductor son los amores humanos y divinos, el jardín desaparece como motivo literario, pierde protagonismo y deja

de cinco actos y las unidades de acción, tiempo y espacio

${ }^{10}$ En uno de los entreactos, Feliciana lo utiliza de forma paródica como nombre de uno de los pretendientes de las gracias mohosas.

11 "Pero no me negarás, Sancho, una cosa: cuando llegaste junto a ella, ¿̇no sentiste un olor sabeo, una fragancia aromática, y un no sé qué de bueno, que yo no acierto a dalle nombre?" Capítulo xxxi (Primera parte del Quijote). 
paso al sentimiento amoroso que lo invade todo. Amores humanos que siguen el código del amor cortés y esconden los sentimientos de la autora y amores divinos que consiguen la fusión del mundo mítico con el caballeresco y en los que la autora se permite toda una serie de transgresiones morales ${ }^{12}$ ya presentes en la mitología clásica- que rompen el "amor honesto y puro" que se profesan los protagonistas mortales.

Una joven en la Sevilla de comienzos del siglo XVII, tenía como destino el matrimonio impuesto por sus padres, Feliciana Enríquez fue obligada a casarse con el viudo Don Cristóbal Ponce Solís, pero cuando comenzó a escribir esta historia sólo podía temer que se cumpliera el destino de tantas otras mujeres. Ya casada, siguió escribiendo la Tragicomedia y pudo verter sus vivencias autobiográficas en la obra. Podemos imaginar que el carácter independiente de Feliciana le hacía manifestar su protesta hacia los varones considerados como un "buen partido" por sus progenitores, su repulsa la lleva a autorepresentarse mediante personajes femeninos míticos que huyen del contacto de un hombre. Como ejemplo de la fascinación que Feliciana siente por las mujeres mitológicas que rehúsan el contacto con varones, Feliciana introduce en su obra la trágica historia de Atalante, Dafne y Siringa estudiada en otros trabajos. ${ }^{13}$

Tres años más tarde muere su marido y unos meses después Feliciana se casa con su primer amor, al que no había podido olvidar: D. Francisco de León Garabito. Los hombres de su vida tienen también una clara representación en la obra: Francisco de León es el príncipe de Esparta Clarisel, el héroe esforzado cuya lealtad le hace esperar a que Feliciana recupere su libertad, nobleza que fue premiada con las bodas entre ambos. Su primer marido Cristóbal Ponce Solís es Vulcano, viejo y poco atractivo, de quien se burlan unos Cupidillos que justifican la infidelidad de su esposa joven y bella. Venus es la esposa traidora, que obtiene la simpatía del lector, comprensivo ante sus amores con Adonis, motivados por la poca atracción que siente por un esposo repulsivo y decrépito:

\author{
Di viejo verde \\ como quieres concuerde \\ con tu pie cojo y copo, \\ con tus manos tiznadas \\ con tus piernas quebradas \\ con tu boca soplona, ojos de topo, \\ los ojos, tez, blancura, \\ la gracia de mi madre y hermosura? ( Pérez 213)
}

${ }^{12} \mathrm{La}$ actitud moral transgresora es una constante en los personajes míticos y alguno de los secundarios: poliandria, travestismo, incesto, adulterio...sin embargo los protagonistas de la Primera parte Clarisel y Belidiana y los de la segunda Clarisel y Maya, mantienen una actitud aceptable para las convenciones morales de la época. No comparto la teoría de Reina Ruiz quien ve en la relación de Belidiana y su padre una clara intención incestuosa, a mi juicio, inexistente. Cf. M. R. Ruiz 2005: 39-68

${ }^{13}$ P. Conde Parrado, C. de la Rosa, 2005: 253-265 
En una obra de claros tintes autobiográficos el tema del amor merece ser tratado en capítulo aparte. Aparecen aquí todos los sentimientos que puede despertar la pasión amorosa: desde la soledad motivada por la ausencia a la desesperación que produce la pérdida del ser amado pasando por la alegría desbordante del amor correspondido. En la obra asoman dos Felicianas: la real, que tuvo que acatar la decisión paterna y casar con un viudo a pesar de sus propios deseos, y la Feliciana soñada, una mujer independiente y audaz que aparece bajo el sobrenombre de Maya.

La Feliciana real se somete a la voluntad del padre implacable ${ }^{14}$, a pesar de que no coincidan con sus propios deseos. Y sufre, por la ausencia de su amado, atroces tormentos, expresados con sentimientos a flor de piel: la ausencia es muerte fiera, los padres crueles alimañas y ella la víctima y trofeo de esta feroz cacería ${ }^{15}$.

La soledad, durante los tres años que duró su matrimonio, es también un tema de la obra que expresa en el Coro del acto IV:

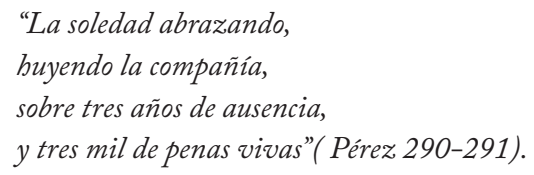

Recuerdos que hieren el alma de los amantes y hacen increpar a la Fortuna que les permitió conocerse para luego separarles y que simboliza con el mito de los amores imposibles de Eco y Narciso ${ }^{16}$.

Tristeza que se expresa en una queja hacia el amado ${ }^{17}$. Desesperación que se convierte en locura recordando el amor perdido en el Coro del acto III. Es la dramática reacción de Venus ante la muerte de Adonis, la enajenación motivada por la pérdida de la persona amada:

\section{Tuerce la diosa sus manos \\ y besa las que excluyeron \\ con su amorosa blancura \\ las tiznadas del herrero. \\ La guirnalda que ceñia \\ el oro de sus cabellos, \\ con los dientes despedaza, \\ como mordida de perro. \\ Hiere sus sacras mexillas, \\ y a las difuntas da besos;}

\footnotetext{
14 "Ay, Clarisel, pues tuve suerte negra/en padre porfiado y riguroso" (Pérez 1988 191)

15 Pérez, 164, C.

${ }^{16}$ Pérez, 288-289.

17 "Vayan a ti mis suspiros/pues eres el que los formas/la razón por que los doy,/bien sé que tú no la ignoras” (Pérez, 314-315.
} 
muerde sus labios, y pone

los del joven muerto en ellos.

Sus blancos braços enlaça

al blanco alabastro terso

de la garganta, que fue

su paz, su gloria, y consuelo.

(Pérez 216)

A pesar de la lejanía impuesta, el enamorado mantiene su lealtad por Feliciana. La lealtad en la relación amorosa se convierte en motivo recurrente de la expresión poética, es el "foedus amoris", el pacto de amor de Catulo hacia Lesbia en la poesía clásica latina, la condición indispensable para que amor llegue a buen fin y que, si se rompe, convierte en sacrílego al que lo incumple ante la mirada de los dioses.

\author{
(...) Porque primero a otro \\ fue prometida por amada esposa \\ de la muger, y potro \\ la fuerza es peligrosa, \\ que quieren mano blanda, y amorosa. \\ Mas no quiero culparte, \\ Arroyo ilustre, que antes fuera amencia. \\ De tal bien despojarte; \\ llore ella su demencia, \\ que no tuvo valor ni fe en ausencia. \\ $Y$ tu, Ojoven constante, \\ Ten ánimo en los golpes de Fortuna, \\ Que a tan leal amante, \\ Guardada tienen una \\ Los hados en la esfera de la luna. \\ Esta es la linda maya, \\ Que en la ciudad hercúlea de Fernando, \\ Por la línea Pelaya \\ Su estirpe derivando, \\ Será princesa del piérido vando. (...) (Pérez, 290)
}

La segunda Feliciana que aparece en la obra lleva el nombre de la mítica Maya, la mayor de las Pléyades a la que no se le pone nada por delante, la misma Venus es su aliada y favorece sus deseos. Maya se reencuentra con Francisco de León en la segunda parte de la Tragicomedia (lo mismo que en la vida real) y ya nadie puede separarles: la relación se convierte en una gozosa descripción de amor y de deseo en el que resuenan los ecos del Cantar de los cantares de 
Fray Luis de León ${ }^{18}$, y se legitima mediante un solemne matrimonio en el que no faltan los dioses del amor, Venus y Cupido, y de las uniones legítimas Juno e Himeneo. Final feliz, pues, para los amores de Maya y Clarisel, los protagonistas de la Tragicomedia que coincide con el final feliz de los amores entre Feliciana y Francisco.

\author{
En los campos Elysios Hymeneo, \\ Juno, y Venus las bodas celebravan \\ De dos esposos, y los coronavan \\ De arrayan, $y$ del árbol de Tymbreo. \\ Caliope, y Euterpe al son que Orfeo, \\ Clio, y Talia en harpas acordavan \\ Sus tálamos felices festejavan \\ De uno, y otro llegados al deseo. \\ De descanso, diziendo, largos años \\ Les dé el divino Amor, y la discordia \\ De sus puertas no passe los umbrales; \\ Entre brocados, y purpúreos paños \\ Maya, y su Clarisel siempre leales \\ Gozen de felicissima concordia. \\ (Pérez 316-317)
}

$\mathrm{Y}$ en esta etapa feliz, Feliciana es Maya, la princesa que consigue el amor de Francisco por su belleza y, lo que es más importante, por su inteligencia ${ }^{19}$. FelicianaMaya no sólo triunfa en el amor, sino que logra la admiración de Sevilla con sus escritos, defiende su preceptiva literaria contra hipotéticos detractores y presume de ser mujer y lograr sus objetivos. Y esta proyección íntima se realiza en el jardín,teatro en el que se funde el mundo real y el ficticio, cómplice de sus sentimientos amorosos y sus anhelos personales, un jardín abierto que simboliza el mundo privado de la autora. La naturaleza domesticada a gusto de su propietaria, donde crece lo que ella quiere y pasa lo que ella quiere que pase.

En conclusión, el motivo del jardín, de una extensísima y compleja tradición literaria, se torna aquí, espacio simbólico ordenado por la mano del artista, en el que se refugia la autora huyendo de una realidad extratextual. Los Jardines y campos Sabeos son, para la autora, un espacio utópico e irreal, un lugar mítico con una reina mítica, un espacio sin puertas ni muros donde a la mujer se le permiten acciones y comportamientos considerados transgresores en el mundo real.

Para Feliciana, entrar en el jardín es entrar en un refugio, escapar a las implacables leyes estéticas y morales de su tiempo. Mientras que en su obra

18 “(...) Quando de amado esposo / El nombre merecido y alcanzado / Te veas, dulce, honroso, / En el solio argentado / De tu bella Diana, y Sol dorado; (...)”./Coro del acto II. (Pérez, 288-289).

${ }^{19}$ Mas la dulçura, mi Maya, / De vuestros versos y rimas, / Es la que ha llegado al alma / Con suave melodía / (II Parte, Acto V, 256, v.342-345). 
paraliteraria (prólogos, dedicatorias, carta a los lectores, carta executoria) se defiende de las acusaciones de los dramaturgos de su época tanto por adoptar los modos clásicos de hacer teatro como por ser mujer en una actividad reservada a varones, en el jardín, su obra es alabada y valorada por hombres y dioses. Mientras que en su vida real deberá someterse a los dictados de una sociedad patriarcal y casarse con un hombre al que no quiere, en el jardín consigue al amor de su vida.

En el jardín, bajo el amparo de la lejanía temporal y el ropaje mitológico dará rienda suelta a sus sentimientos y se expresará con entera libertad. Feliciana convierte así el espacio dramático en un espacio soñado, la interpretación de ese espacio imaginario tiene una funcionalidad clara: es el medio de lograr la autoafirmación de Feliciana como mujer y como autora teatral.

\section{Bibliografía}

A. Egido (ed.) (1989), La escenografía del teatro barroco. Salamanca.

A. Egido (1990), Fronteras de la poesía en el Barroco. Barcelona

C. Hernández Varcárcel (1984), "EI locus amoenus en la Edad Media española" in Simposio Virgiliano. Murcia 321-340.

C. de la Rosa Cubo (2005), "Educación y Herencia Clásica en las escritoras españolas de los siglos XVI y XVII" in Mujeres y educación. Saberes, practicas $y$ discursos en la Historia. Sevilla 161-173.

E. R. Curtius (1977), Literatura europea y Edad Media Latina, Méjico.

J. De Lara Garrido (1995), "El Jardín y la imaginación espacial en el teatro barroco español”, in C. Añón Feliú (Dir.), Jardines y Paisajes en el arte y en la Historia. Madrid 109-156

L. Pérez (1988), The dramatic works of Feliciana Enríquez de Guzmán, Valencia

M. R. Ruiz (2005), Monstruos, mujer y teatro en el barroco. Feliciana Enríquez de Guzmán. Primera dramaturga Española. New York.

O. Arróniz (1977), "Teatros y escenarios del Siglo de Oro”, in J. M. Díez Borque (dir.), (1991), Espacios teatrales del Barroco.Reichenberger. Madrid, Gredos.

P. Conde Parrado, C. de la Rosa (2005) "Una lectura de Ovidio en el drama español del s. XVII: La Tragicomedia de los Jardines y los Campos Sabeos de Feliciana Enríquez de Guzmán”, in Ecos silenciados Burgos. 253-265

T. Ferrer Valls (1991), La práctica escénica cortesana: de la época del Emperador a la de Felipe III. London. 


\title{
PAISAGEM DO CÁRCERE O TOPOS LITERÁRIO NUMA EPOPEIA NEOLATINA
}

\author{
Carlota Miranda Urbano \\ Universidade de Coimbra
}

\begin{abstract}
The isolation imposed by a locked, dungeon setting makes such setting to appear as the ground of definite boundaries, the "no-landscape" setting. Nevertheless, when the dungeon environment really holds sway, the human spirit's irreducibility to those four walls stands out. It is a that point that the power of word and narrative allows the world-space to be taken into the dungeon setting; the human spirit can afford then the possibility of journeying in time and space, even inside his innermost being.

This essay aims at highlighting the wealth of classic tradition lying behind "the dungeon" literary topos as a space of meaning. While other classic texts are discussed as well, the main literary corpus being dealt with is a specific Virgil-style, Neolatin epopee. The piece is made of twelve chants, six of which take place inside a particular dungeon.
\end{abstract}

Tomar o cárcere como tema num congresso da APEC sobre 'espaço e paisagem' pode parecer descabido ou contraditório. $\mathrm{Na}$ verdade, o isolamento imposto pelo cárcere é o espaço da não paisagem, é, por excelência, o espaço da privação do mundo, dos limites estreitamente definidos, da ausência de relação e da restrição da liberdade. Mas é precisamente por estes motivos que o cárcere constitui inúmeras vezes o ponto de partida para a evasão ilimitada através do sonho e da ficção, ou o momento privilegiado para a libertação do homem interior, irredutível aos limites que lhe são impostos.

Como topos literário, o cárcere carrega uma longa e rica tradição, quer como espaço de sofrimento e de redenção, quer ainda como metáfora da condição humana entre os limites do finito e a ânsia do infinito, numa longa permanência da imagem platónica do corpo como cárcere. O corpo, a vida, o próprio ser, como o exprimiu Fernando Pessoa num poema metafísico de 
Álvaro de Campos, quando, face ao mistério do 'ser', desabafa: “Cárcere do Ser, não há libertação de ti? /Cárcere de pensar, não há libertação de ti?".

A imagem do homem como 'ser encarcerado' tem sido expressão de um desejo, por definição, humano: o desejo de mais e de liberdade.

Mas tomemos o subtítulo desta comunicação. $\mathrm{O}$ corpus a que nos reportamos é um poema épico neolatino, o Paciecidos do jesuíta Bartolomeu Pereira que canta a epopeia dos missionários jesuítas no Japão tendo por tema central o martírio do Beato Francisco Pacheco e de mais oito companheiros. Alguns deles partilharam o cárcere no forte de Ximabara entre Dezembro de 1625 e Junho de 1626.

A acção desta epopeia, de modelo marcadamente virgiliano, desenrola-se ao longo de doze cantos e, de acordo com a dispositio clássica, tem início in medias res. Concentrada nos últimos meses de vida destes heróis, o plano da narrativa principal concede grande destaque ao tempo passado na prisão. $\mathrm{Na}$ verdade, mais de um terço dos doze cantos passa-se no cárcere. Depois de um exílio imposto em Macau e do regresso ao Japão na clandestinidade, o herói principal é preso no canto IV. No final deste canto, Francisco e alguns dos seus companheiros ficam encarcerados no forte de Ximabara. Só durante o Canto $X$ tem lugar a viagem dos jesuítas para Nagazaki onde serão executados (no canto XII). Portanto, desde o canto V ao IX e parte do X, a acção passase nos limites do cárcere. No entanto isto acontece só no plano da narrativa principal. $\mathrm{Na}$ verdade, três destes cantos constituem uma longa analepse em que, conforme o modelo homérico-virgiliano, o herói da epopeia faz o relato ab ouo, isto é, dá a conhecer aos companheiros da prisão e ao leitor, as origens da sua família, a sua pátria, a sua entrada na Companhia de Jesus, as peripécias da viagem até Goa, e daí ao Japão, o naufrágio, a missão no Japão, o exílio em Macau, o regresso e, finalmente, a perseguição que termina no cárcere.

Todos estes factos, porém, que constituem do ponto de vista do carácter hagiográfico da obra, o que mais corresponde ao tipo da biografia devota, são recheados de episódios fantásticos cheios de ressonâncias homéricas. Desde o episódio protagonizado por alguns dos companheiros de viagem que são atacados por um dragão na Ilha de S. Lourenço, até ao aparecimento da alegoria feminina da Piedade que vem ao encontro de Francisco depois da sobrevivência a um naufrágio. É esta jovem Piedade que lhe indica o caminho até à casa de um agricultor onde será acolhido como hóspede. São várias as narrativas menores a enriquecer literariamente a analepse que dura, no plano da narrativa principal, o tempo de uma noite. O leitor esquece-se de que a acção se passa no cárcere e o poeta também não se preocupa em lembrá-lo. É uma longa narrativa dentro de outra. Nos limites do cárcere, e a pedido dos companheiros, o herói evoca durante a noite a sua história e é o amanhecer que lhe põe fim.

Mas o cárcere não é apenas o cenário desta analepse e numa epopeia que celebra o heroísmo do martírio, ele constitui um motivo literário bastante

1 «Ah, perante esta única realidade que é o mistério...». F. Pessoa, Obras completas. Lisboa, Ática (1970-1980), vol II. 
explorado neste poema. Podemos dizer que o cárcere sofre neste poema uma verdadeira transfiguração. Ele começa por ser o antro escuro, imposto pelo tirano, a privação da liberdade, o lugar do sofrimento e da tortura mas, como veremos, será espaço de luz e de libertação. No início do Canto $\mathrm{V}$, o poeta invoca Apolo, pede-lhe que entre com ele no cárcere para revelar ao mundo o que se passou nas trevas da prisão.

"E agora, Apolo, que outrora tantas vezes penetraste nas sombras horrendas e nos antros da Sibila, eu te suplico: entra comigo por um instante nesta horrivel fortaleza, nas estreitas passagens, nos antros ocultos daquele cárcere, expulsa-me do peito o vão temor. Porque não rompes esse silêncio profundo? (...) O corpo sim, mas o espírito não pode ser encarcerado; a nobre virtude de Francisco venceu as cadeias. ${ }^{2}$

Francisco, que partira para o Oriente no cumprimento de uma vocação universal, é sinal de contradição. $\mathrm{Na}$ sua juventude ouvira o lema missionário: Francisco deve ser para todo o mundo e todo o mundo para Francisco." (7, 174). Apesar disso, Francisco,

\begin{abstract}
"a quem a sua terra lusa, a inteira India, a China, a quem o Japão, todo o mundo, as ondas do mar e todo o universo não bastaram, eis que o retém estreita morada, ei-lo cercado de grades no meio de um cárcere, lugar imenso em sofrimento, mas que para ele é, de longe, mais grato e mais espaçoso que a corte de Ciro. "’3
\end{abstract}

Mas esse cárcere que impõe o limite rapidamente se converte no espaço privilegiado da ascese e através dela o homem interior ganha poder sobre os limites do corpo, também ele visto como prisão do espírito que só poderá alcançar a liberdade completa na morte.

É impossível ler profundamente este texto do séc. XVII sem reconhecer nele o intertexto da primeira interpretação cristã do martírio, marcada pela determinante relação do cristianismo primitivo com as correntes filosóficas estóicas e neoplatónicas. Tertuliano e a sua breve exortação aos martyres designati, como lhes chama, oferecem-nos uma boa leitura do cárcere como espaço de ascese, mas de um modo geral ela integra as tipologias literárias do martírio na primitiva literatura cristã, especialmente nos relatos dos Acta Martyrum.

Nestes textos frequentemente sucede que o mártir passa pelo cárcere como por um tempo de ascese e preparação que pode anteceder o momento

${ }^{2}$ Nunc age, deformes umbras, atque antra Sybillae/ Qui quondam toties intrasti, Delphice, mecum/ Nunc, precor, horrentem hanc arcem, nunc carceris huius/ Angustos aditus, latebrosaque tecta parumper/ Ingredere, et uanos e corde expelle timores. (...) ecquid non alta silentia rumpis?/ (...) Corpora, non animos, uinciri: altamque Paceci/ uirtutem , medias inter regnare catenas. $5,1-5,14,16-17$.

${ }^{3}$ Ergo Franciscum, cui non sua Lysia, et omnis/India, non Sinae, cui non Iapponia, cuique/ non tellus, non unda maris, non sufficit orbis,/Iam locus in media uallatum cratibus arce/ detinet angustus, poenis satis amplus, et ipsi/ gratior, et Cyri longe spatiosior aula. 5, 18-23. 
da confissão de fé diante do tirano ou a tortura, ou ainda a execução. Tertuliano, na exortação a que acima nos referimos, sugere aos destinatários que aproveitem a prisão do corpo para libertar a alma em direcção a uma união mais próxima com Deus. Se a Ele estiverem unidos, resistirão à dor:

"Por isso, benditos, por mais duro que seja (o cárcere), tomai-o como exercitação das virtudes do espirito e do corpo. Preparais-vos para combater o bom combate em que o agonoteta é Deus vivo, o xistarco o Espírito Santo, a coroa, a da eternidade. ${ }^{4}$

Este também é, porém, o lugar em que se proporcionam os momentos de oração, de visões místicas, ou ainda de sonhos reveladores do prémio do martírio. Geralmente, depois destas visões em que o mártir contempla o paraíso, assistimos à sua profunda transformação. Frequentemente o cárcere, para além de se poder transfigurar em palco de visões e sonhos, pode ser cenário de prodígios como a conversão dos próprios carcereiros.

Podemos assinalar todos estes traços no Paciecidos, cujo significado se torna mais profundo e mais amplo se reconhecermos este intertexto. Também Pacheco e os seus companheiros têm no cárcere ocasião de ascese e de combate espiritual.

"O cruel Táquea, pois, exercia a sua raiva contra o forte de Ximambara e seus prisioneiros, acrescentando às cadeias todo o género de tormentos: ora é um guarda que os ameaça com a espada, ora é a fome que os atormenta, ou ensurdecem com grandes gritos os seus ouvidos; de noite, os seus olhos não têm trégua de repouso; o solo é o duríssimo leito para os seus membros, e um tronco o rude travesseiro para a sua cabeça. Em tais sofrimentos, porém, a mais bela virtude alimenta as forças e uma valentia secreta."

Quando havia pausa nos tormentos, os prisioneiros procuravam voluntariamente fustigar o corpo, até não sentirem mais cuidado nas coisas mundanas, dominados pelo ardor de render inteiramente o espírito ao Amor divino por meio da morte. A penitência e as lágrimas dos presos que anseiam pelo martírio transformam-se paradoxalmente em expressão da sua felicidade.

"Mas nas lágrimas recrudesce o seu amor e recobra as forças adormecidas, como com as gotas de água cristalina, o fogo, atacado, se irrita e recupera o seu vigor. E o mesmo ardor a todos possui.

${ }^{4}$ Proinde vos, benedicti, quodcumque hoc durum est, ad exercitationem virtutum animi et corporis deputate. Bonum agonem subituri estis in quo agonothetes Deus vivus est, xystarches Spiritus Sanctus, corona aeternitatis. $(3,3)$

${ }^{5}$ Ergo Ximabarae crudelis in arce Taquea/ Exercet rabiem in uinctos, atque omne catenis/ Tormentum adiungit; minitans hinc inde satelles/ Stat gladiis; furit ore fames, clamoribus aures/ Surdescunt; sunt nullae oculis cum nocte quietis/ Indutiae; dat strata solum durissima membris,/ et capiti inclemens dat puluinaria robur./ His tamen in poenis uirtus pulcherrima uires/ Occultosque animos haurit (...). 5, 100-108. 
A ira cruel dos guardas, a morte viva, todo o género de atrocidade, beberam-no com avidez, $e$ sofriam de rosto alegre."

Fortalecidos pela ascese, os prisioneiros vencem a tentação do Caecus Amor. O deserto e a solidão foram desde sempre na tradição judaico-cristã o espaço de encontro com Deus, mas também o da tentação. Para os confessores (assim se designavam os presos que aguardavam o julgamento e eventualmente o martírio) o cárcere é também espaço onde entra 'o tentador'.

Perante a vitória dos prisioneiros, os guardas do cárcere, movidos pela contemplação das suas obras, abandonam a severidade e procuram suavizarlhes o sofrimento, desejam conhecer a sua fé e um deles pede o baptismo.

Deixando de lado o significado doutrinal desta conversão e o do valor nela atribuído à contemplação das obras, centremo-nos na transfiguração do cárcere. Lentamente, o brilho da virtude dos prisioneiros produz os seus efeitos, amansando os algozes que, dispostos a ouvir a exortação de Francisco Pacheco abrem o coração à sua doutrina. $\mathrm{O}$ cárcere fica então dominado pelo amor e verdadeiramente transfigurado. Escreve o poeta:

"Eu sou testemunha das vossas crueldades, da fúria resistente que há pouco tinheis no coração. Agora, revestidos de um espirito brando e coração de cera, juntais-vos ao velho lusitano e aos companheiros, não pela antiga cadeia, nem pelo pesado ferro, mas por um amor eterno...."

Depois desta vitória o herói principal é acometido de nova tentação. A Vã Glória apresenta-se insinuando-lhe com a aparência de bem que não há vitória superior à sua. Ela não custou vidas, nem sangue a ninguém. S. Paulo pode orgulhar-se de ter gerado um cristão no cárcere, Onésimo, mas Pacheco gerou muitos mais. E termina assim o seu discurso:

"tu próprio, Francisco, no cárcere fecundo e nas tuas cadeias geraste muitos mais para Deus, ó bem-aventurado! Esta vitória merece maior coroa, maior louvor. Não deves esperar mais; sai da prisão, vencedor!"'

Mais uma vez, fortalecido pela ascese, o herói sai vitorioso com o discurso da humildade.

${ }^{6}$ Sed lacrymis crudescit amor, uiresque resumit/ Sopitas, uitreae ceu lymphae aspergine crescit,/ Adtollitque animos, laesusque irascitur ignis./ Idem omnes simul ardor habet, saeuosque furores/ Custodum, uiuasque neces, et quidquid acerbum est/ Exhausere auidi, et laeta sic fronte tulere;/."5, 154-159.

7 ...uestrumque manus, atque effera testor./ Facta reluctantesque olim sub corde furores./ At nunc iam molles animos, et cerea corda/ Induti, Lysiumque senem, sociosque catena/ Pro ueteri, proque aere graui religastis amore/ Aeterno (...). 5, 310-315.

8 (...) ipse Deo fecundo in cárcere plures,/inque tuis uinclis genuisti, Diue. Coronam/ maiorem, et plures petit hec uictoria lauros./ Nil ultra expectandum; exi de cárcere uictor! (6, 460-463) 
A transfiguração do espaço do cárcere, porém, vai mais longe ainda quando, depois destes prodígios, os prisioneiros se entregam à oração. Francisco Pacheco é arrebatado numa intensa experiência mística em que contempla o Paraíso.

\begin{abstract}
"Concedeu-lhe asas o Amor e, assim, em espirito, sobe às auras celestes, medita na mansão dos Santos, entra na fortaleza do Olimpo, na cidade e nos muros de Sião, construida no oiro puro, de telhados de pedras preciosas que nem o inverno ruinoso, nem os duros combates do vento veloz ou o passar dos anos podem perturbar; Ali já não há prisão, nem cadeias de ferro, não existe Mondo, nenhum guarda ou sentinela inflige torturas, nem o mar da humana realidade se perturba; mas os seus divinos habitantes entoam hinos de louvor a Deus e jubilosos, cantando em coro, recebem as almas dos que chegam ao Reino dos Céus; onde reina o amor, onde se perpetuam as alegrias e as delicias de uma felicidade eterna."
\end{abstract}

A visão antecipada do paraíso antes da execução do mártir, tópico recorrente na hagiografia martirial é, no fundo, o que aqui temos no arrebatamento místico de Pacheco.

Esta transfiguração máxima é abruptamente interrompida pelo exterior, pelas forças que na epopeia se opõem ao herói. A Fama levara ao tirano a notícia paradoxal de que quem mandava agora no cárcere eram os próprios prisioneiros. Mondo, o tirano, enviara então ao cárcere um seu parente conhecido pela dureza e severidade, Densamono. Só que também a este, as obras do herói moveram, penetrando no seu peito. O cruel guardião dos deuses nipónicos, depois da disputa teológica com o herói lusitano, rende-se à nova religião. Os guardas de Mondo invadem então o cárcere para levar os prisioneiros ao palácio do Governador onde alguns são interrogados, após o que são enviados para Nagasaki onde serão executados.

São os próprios prisioneiros, pois, que entregues à ascese e ao sacrifício, transfiguram a paisagem do cárcere.

Como definira Tertuliano na exortação que temos vindo a evocar:

"Por isso, benditos [mártires], deveis concluir que talvez ten hais trocado o cárcere pela fortaleza segura. Nele há trevas, mas vós próprios sois a luz, nele há cadeias, mas vós sois livres para Deus. Nele respirais um odor pestilento, mas vós próprios sois odor de suavidade. ${ }^{10}$ Espera-vos o

\footnotetext{
${ }^{9}$ Vtque alas concessit Amor, super aetheris auras/ Mente subit, Superumque domos meditatur, et arces/ Intrat Olympiacas, murosque urbemque Sionis,/ Extructam solido ex auro, gemmantia cuius/ Tecta nec imber edax, rapidi nec ahenea uenti/ Praelia, non aeui poterit mutare uetustas;/ Nullus ubi est carcer, non ferrea uincula, Mondus/ Nullus adest; nullusque uigil custosue procellas/ Excitat, aut rerum mare fluctuat humanarum;/ Sed diuina sacri celebrant encomia ciues, / Et laeti uenientum animos ad regna choreis/ Excipiunt; ubi regnat amor, semperque perennant/ Gaudia, deliciaeque, immortalisque uoluptas. 10, 5-17.

${ }^{10} \mathrm{O}$ mártir constitui para Deus o suave odor de Cristo. Recorde-se o escreve S. Paulo sobre os cristãos: "Somos para Deus o bom odor de Cristo entre os que se salvam e os que se perdem" (2 Cor, 2,15). O suave odor do sacrifício de Cristo e dos mártires, encontra-se, associado na mais antiga literatura martirial, ao perfume apaziguador dos holocaustos judaicos, pressupondo a sua oposição ao odor pestilento dos sacrifícios oferecidos aos ídolos.
} 
julgamento, mas vós próprios julgareis os juizes. Entristece-se nele aquele que suspira pelos bens do século. O cristão, porém, já renunciou ao século, mesmo fora do cárcere, e no cárcere, renuncia também ao próprio cárcere."

\section{E mais à frente dirá}

"Embora o corpo esteja encerrado e a carne presa [pelas cadeias], ao espirito tudo se abre, Sempre que viajares em espirito, não ficas no cárcere. O corpo nada sente se o teu espirito estiver no се́u."12

Os cristãos, segregados no cárcere, estão realmente livres, pois o mundo é ele mesmo um cárcere, e o cárcere é o lugar da liberdade dos cristãos.

Transfigurado o cárcere em lugar de libertação crescente que permite aos heróis a contemplação da glória celeste, a morte há-de garantir a libertação plena e definitiva da prisão do corpo. As almas destes heróis chegam então, em apoteose gloriosa, à mansão celestial.

Por esta morte no fogo, já Francisco Pacheco tinha suspirado:

"porque cuidais em protelar a minha morte com tantas lágrimas comprada, em tantas preces suplicada? Não foi prometida tal esperança a Pacheco? Entregai, Rei Magnifico, este corpo à fúria das chamas, desatai as minhas cadeias. "13

A morte através do fogo, associada à purificação, à destruição completa da matéria e, no caso da cultura clássica, à divinização do herói e à sua apoteose, oferece ao poeta motivos expressivos que ele explora com mestria. Francisco Pacheco e os companheiros ascendem de imediato à glória enquanto os seus corpos ardem nas chamas. Eles são novas Fénix renascidas. "Ah Fénix, como partes feliz! como desprezas as iras de Vulcano, e rejubilas de renascer das chamas! Como voas formoso e resplandecente!"14 escreve o poeta.

Mesmo as suas cinzas lançadas nas águas do mar são signo da libertação final do cárcere que reteve os corpos mas não as vontades, são signo da libertação do cárcere que foi o corpo, agora desfeito. Dispersas e misturadas nas ondas,

11 Quo vos, benedicti, de carcere in custodiarium, si forte, translatos existimetis Habet tenebras, sed lumen estis ipsi; habet vincula, sed vos soluti Deo estis. Triste illic exspirat, sed vos odor estis suavitatis. Iudex exspectatur, sed vos estis de iudicibus ipsis iudicaturi. Contristetur illic qui fructum saeculi suspirat. Christianus etiam extra carcerem saeculo renuntiavit, in carcere autem etiam carceri. 2,4.

${ }^{12}$ Etsi corpus includitur, etsi caro detinetur, omnia spiritui patent. (...) Quotiens eam spiritu deambulaueris, totiens in carcere non eris. Nihil crus sensit in neruo, cum animus in caelo est. 2, 9-10.

${ }^{13}$ quid nostra moratis/ Gaudia? Tot lacrimis emptam uotisque petitam/ Cur mortem diferre paras? Haec illa Paceco/ Est promissa fides? Corpus, rex magne, furenti/ Da tandem flammae, meque his exolve catenis." 10,21-31.

${ }^{14}$ Ah Phoenix, quam laetus abis! Quam despicis iras/Vulcani gaudesque tuis tuis pubescere flammis!/ Quam flauus, quantoque uolas formosior! (...) 12,167-174. 
as cinzas dos companheiros simbolizam a união sem limites, o vínculo da caritas que os une entre si e aos fiéis, embora estes tenham ficado privados das suas relíquias. A fusão dos seus corpos pelo fogo e na água é aproveitada pelo poeta como representação daquele vínculo de unidade e paradoxalmente como símbolo de glória.

\begin{abstract}
"Vós, porém, ide, pias cinzas, usadas e acostumadas aos perigos do mar, ide, congregadas no cimo das ondas. Esta união de morte, não há cárcere, nem chama feroz, nem onda que a possa romper (...) Não te levaram por inteiro, Pacheco, nem a ti João. Grande parte de ti, Rinxei, e de ti também, Torres, ficam connosco no fundo do coração; gravados na nossa alma. A pureza dos vossos costumes e as vossas imagens hão-de permanecer e viver para sempre. O espirito cego do tirano nega-vos o dom de um pequeno pedaço de terra a descoberto, a terra, comum a todos nós, e dá-vos por túmulo, todo o oceano, no vosso sepulcro cabe todo o mar, todo aquele que estiver debaixo do sol." ${ }^{15}$
\end{abstract}

São evidentes neste poema as ressonâncias da mais antiga literatura martirial e da patrística na construção literária do herói mártir. É muito visível também nessa construção a influência estóica. Para ela concorrem, por um lado, a presença significativa das relações entre o estoicismo e o cristianismo na primitiva literatura cristã, e de modo especial na configuração das primeiras tipologias do martírio e da santidade. A literatura patrística e de tema martirial carregava ela própria uma específica recepção do estoicismo e funciona claramente nesta epopeia como inter-texto. Por outro lado, o humanismo de quinhentos e de seiscentos concede extrema atenção à ética estóica, quer vista como absolutamente antagónica, que como conivente com o cristianismo.

Este fenómeno não é exclusivo do texto filosófico, antes se estende a vários géneros literários, desde o encómio, à epistolografia consolatória, passando pela poesia, nomeadamente a épica, que pretende, esta última, representar o triunfo da virtude e do herói, isto é, do homem em acção. ${ }^{16}$

Longe de abordar a questão estóica do ponto de vista da polémica filosófica, a poesia reflecte as relações entre os pensamentos estóico e cristão, ou mais do que isso, revela na configuração da personagem heróica uma cristianização do estoicismo, deixando para o debate filosófico a decisão sobre a compatibilidade ou não entre ambos. O leitor poderá concluir da profunda incompatibilidade entre a autarcia ou autodeterminação do herói estóico e a confiança do mártir cristão no poder de Cristo que nele sofre o martírio, mas o poeta não o explicita.

Não podemos deixar de ver um outro intertexto neste poema, para além da literatura patrística. A biografia antiga, mas sobretudo o género dos exitus

15 "Sed uos, aequoreis noti assuetique periclis, / Ite pii cineres, indiscretique supremis/ Fluctibus; haec tanti commercia rumpere leti/ Non carcer, non flamma ferox, non unda ualebit" 12 , 338-341.

${ }_{16}$ Para esta matéria veja-se Stoicisme et christianisme à la Renaissance. Paris, Cahiers V.L. Saulnier, 23, 2006. 
illustrium uirorum são reconhecíveis na morte destes mártires, que soam a morte do sapiens estóico, especialmente enquanto retratados no desprezo dos bens exteriores, da dor e da morte. Tal como algumas figuras dos Annales de Tácito, verdadeiros 'mártires', como lhes chama Cristina Pimentel, ${ }^{17}$ estes exempla do séc. XVII poderiam pronunciar as palavras que Epicteto coloca na boca de Laterano: "Amarrarás as minhas pernas, mas quanto à minha vontade ela será livre, nem o próprio Júpiter ma pode tirar." 18

Um traço de descontinuidade, porém, é visível: o orgulho do sábio estóico que reencontramos até certo ponto na arrogância do mártir diante do tirano, (sobretudo o mártir dos primeiros séculos do cristianismo celebrado em Prudêncio, por exemplo) cede, no louvor do mártir cristão dos séc. XVI e XVII, à atitude humilde, serena e tranquila. Este é certamente um efeito da crítica ao orgulho do sábio que encontramos no humanismo cristão, p. exemplo de Erasmo, ou de Montaigne. ${ }^{19}$

Quanto à continuidade, ela é bem visível, como procurámos demonstrar brevemente ao estudar o tratamento do topos literário do cárcere. No sapiens estóico e nesta tipologia do mártir, manifesta-se o homem livre por excelência.

No corpus que analisámos, o cárcere é o espaço de manifestação da liberdade do homem interior, irredutível às suas paredes ou ao poder do tirano e por isso a sua paisagem pode ser a paisagem sem limites, até mesmo, e paradoxalmente, a paisagem da liberdade.

17 C. C. S. Pimentel (2004), “Virtus ipsa: O retrato literário nos Annales de Tácito” in O Retrato e a Biografia como estratégia de teorização política, coord. Jiménez, J.Ferreira e M.Fialho (Coimbra-Málaga 65-82), esp. 67.

${ }^{18}$ Epicteto, 1, 4. Citação de Jean Brun (1986) O Estoicismo, tradução de João Amado do original Le Stoicisme. (Lisboa Edições 70) 86.

${ }^{19}$ Veja-se a este propósito L. Petris (2006), "LHospital, Pibrac et Montaihne: trois magistrats-écrivains face au néostoicisme chrétien”, in Stoicisme et christianisme à la Renaissance. Paris, Cahiers V.L. Saulnier, 23, 71-91. 
(Página deixada propositadamente em branco) 


\title{
AS MINAS DE OURO DAS AMÉRICAS NOVOS ESPAÇOS PARA A IMAGINAÇÃO CIENTÍFICA
}

\author{
Alexandra de Brito Mariano \\ Universidade do Algarve \\ amariano@ualg.pt
}

\begin{abstract}
By the mid seventeen hundreds, Brazilian José Basílio da Gama wrote Brasilienses aurifodinae ([Roma], c. 1762), a Latin poem included in a long tradition of didactic poetry, which at that time would make itself evident in texts, written both in Europe, and the New World, referring to the subject of gold, and its mining. To support this are provided examples such as the Aurum (Paris, 1703) by French Jesuit Antoine le Febvre, the Metallurgicon (Tyrnau, 1748), by Hungarian Jesuit Joseph Bartakovics, and the Rusticatio mexicana (Bolonha, 1782) by Rafael Landivar's (SJ).

Evidence is thus given for the fact that didactic poetry persisted throughout the ages, depicting itself in poetic production with various linguistic uses and diverse levels of expanding scientific detail, but with an ever present didactic intent; they can be viewed today as a set of relevant examples of the Society of Jesus' spirit of scientific inquiry, as well of historic commitment to gold lore.
\end{abstract}

Keywords: Americas, History of Science, Mining, Neo-Latin, Poetry, Society of Jesus.

Palavras-chave: Américas, Companhia de Jesus, História da Ciência, Mineração, Neolatim, Poesia.

Enquanto durou o Setecentos, um significativo conjunto de jesuítas dedicou-se à elaboração de poemas didácticos sobre os mais variados assuntos, de que nos convém destacar aqueles que abordam temas de cariz científico. Usaram, para esse efeito, predominantemente o Latim; proficientemente aprendido durante a formação nos Colégios da Companhia, e que detinha ainda o estatuto de língua franca da erudição e da circulação do conhecimento, neste período em que desponta o espírito científico que hoje se estabeleceu como paradigma dominante da racionalidade.

Françoise Waquet destaca, com efeito, que apesar do uso das línguas vernaculares se ter tornado predominante, o Latim foi a língua por excelência da difusão do conhecimento no mundo ocidental civilizado até meados do século XVIII. ${ }^{1} \mathrm{O}$ que se nos afigura como trabalho árduo, era então entendido

\footnotetext{
${ }^{1}$ Cf. F. Waquet 2002: 81-2.
} 
por muitos como uma prática recreativa, ${ }^{2}$ que proporcionava sentimentos de pertença e identificação entre os membros de determinados círculos, de marcado carácter elitista.

Vários destes autores abordaram temas mineralógicos em poemas didácticos, com particular atenção prestada ao ouro, em que é possível encontrar características particulares e interligações poéticas que nos permitem relacioná-los. Convocamos aqui o poema Aurum, da autoria do jesuíta francês Antoine le Febvre, editado em Paris, em 1703 - e que mereceu a atenção do periódico oficial da Companhia ${ }^{3}$ - e o Metallurgicon, poema em dois livros, com apêndices em alemão e húngaro, escrito pelo poeta jesuíta magiar Joseph Bartakovics e publicado em Tirnau em $1748 ;{ }^{4}$ citam-se também dois poemas posteriores, da segunda metade do século XVIII, que demonstram que o interesse pelo ouro não se restringiu ao Velho Mundo. Trata-se do Brasilienses aurifodinae, redigido provavelmente em Roma, por volta de 1762, pelo exjesuíta brasileiro José Basílio da Gama, e da Rusticatio mexicana, da autoria do inaciano guatemalteco Rafael Landivar, que inclui livros sobre a prata e o ouro (livros 7 e 8), com uma primeira edição datada de 1781, em Modena, rapidamente seguida por uma versão revista, publicada em Bolonha em 1782, que utilizamos. ${ }^{5}$

Importa lembrar, antes de mais, alguns elementos biográficos dos poetas em apreço, que permitem compreender melhor o contexto e motivação das suas obras. Comece-se por referir que a informação biobibliográfica acerca de Le Febvre é escassa. Ao certo, sabe-se que nasceu em 1670 em Clairvaux, no Jura francês, e que ensinou humanidades na sua província. Antes de 1703, data da edição do seu poema sobre o ouro, foi chamado a Paris, para leccionar no Colégio Louis-le-Grand, cidade onde morreria a 16 de Setembro de 1737.

Também escasseiam os detalhes sobre Joseph Bartakovics. Nasceu em Szalakuz, na actual Eslováquia, em 1722; foi admitido na corporação jesuítica aos 18 anos. A sua formação foi semelhante à de muitos outros jesuítas: tornou-se professor, leccionou filosofia, história, direito e teologia na que é hoje Kosice, capital da Eslováquia oriental, mas que na altura integrava a Hungria setentrional, onde se estabelecera uma universidade jesuítica em 1657, com faculdades de filosofia, teologia e línguas. Bartakovics faleceu em 1763, na sua cidade natal.

Quanto a Basílio da Gama, nasceu perto da vila de São José do Rio das Mortes, que é a actual cidade de Tiradentes, em 1741. Entrou para o colégio jesuíta do Rio de Janeiro, em 1757, onde concluiu o noviciado e toma votos. Porém, a Companhia de Jesus é extinta por ordem do Marquês de Pombal em 1759, e os seus membros são expulsos de Portugal e das colónias; muitos buscam

${ }^{2}$ A expressão é de Haskell 2003: 6, 210 e 220 n. 120, por exemplo.

${ }^{3}$ Cf. Journal de Trévoux (1703): 1038-1044. Para as citações de Aurum, segue-se a 1. ${ }^{\mathrm{a}}$ edição do poema (vide bibliografia). C. Sommervogel, vol. 3, 577 e 558.

${ }^{4}$ Sobre o autor e a sua obra, ver C. Sommervogel 1890, vol. 1, 962.

${ }^{5}$ Cf. bibliografia. 
protecção nos Estados Pontifícios, como foi o caso deste poeta brasileiro que, durante o curso destes eventos, terá abandonado a Sociedade. É pouco o que se sabe da sua vida posteriormente aos anos de setecentos e sessenta, salvo que se encontra em Lisboa em 1774, empregado na administração pública, e aí vem a falecer em $1795 .{ }^{6}$

Rafael Landívar nasceu na cidade de Santiago de los Caballeros de Guatemala, que hoje é conhecida como Antigua, em 1731 e ali estudou no seminário jesuíta de San Francisco de Borja. Abandonou a Guatemala em 1749, rumando ao México, onde, em Tepotzotlán, ingressou no ano seguinte nos efectivos da Companhia. Em 1761, regressou à Guatemala, de onde foi expulso em 1767, e, depois de um percurso atribulado, fixou-se em Bolonha, onde viria a morrer em 1793. Em vida, ensinou filosofia e retórica; a Rusticatio mexicana foi escrita quando procurou refúgio em Itália, em condições semelhantes ao autor do Brasilienses aurifodinae, anos antes. ${ }^{7}$

Educados no seio da Companhia, estes autores beneficiaram seguramente do contacto com a volumosa correspondência que os membros do Instituto, das casas da Ordem e do Quartel-General trocavam entre si. Essa correspondência constitui um contributo relevante para a circulação e disseminação do conhecimento científico entre as várias províncias da Companhia de Jesus como destaca Steven Harris. ${ }^{8}$ Um tal intercâmbio cultural transcendia, pois, fronteiras geográficas e permite-nos falar duma comunidade internacional de correspondentes que, de forma atenta e industriosa, comunicam entre si o produto da sua erudição.

Com efeito, é possível estabelecer que pelo menos um destes poetas teve conhecimento do poema didáctico acerca do ouro redigido por outro membro da sua ordem - tal é o caso de Basílio da Gama, que refere o poema de Le Febvre, de forma aliás pouco elogiosa, no prefácio do Brasilienses aurifodinae (11. 2-6), para sublinhar as dificuldades que o francês teria ao compor a sua obra, resultantes da sua inexperiência empírica relativamente ao assunto aí abordado.

Basílio da Gama terá eventualmente contactado com o Aurum na biblioteca do Colégio do Rio de Janeiro onde estudou, a fazer fé em Serafim Leite, que refere que a mesma se mantinha permanentementeactualizada, ${ }^{9}$ ou, em alternativa mais provável, em Roma, beneficiando do liberal acesso à informação distribuída pelas excelentes bibliotecas daquela cidade, no convívio com letrados coevos. Apesar desta constituir evidência única dum contacto efectivo entre os autores de que nos ocupamos, são recorrentes, por

\footnotetext{
${ }^{6}$ Informação mais detalhada sobre a biobibliografia deste autor em V. Chaves 2000: 9-11.

${ }^{7}$ Para um estudo recente sobre a vida e obra de Landívar, cf. A. Laird 2006.

${ }^{8}$ S. Harris 2000: 228-229.

${ }^{9}$ Em 1760, teria provavelmente 6000 volumes: livros de ciências sagradas e profanas e as últimas novidades. S. Leite 1945, Vol. 6: 26 ss.
} 
outro lado, nestas obras os tópicos paralelos convergentes no tratamento do precioso metal.

Le Febvre abre o Aurum com uma proposição (vv. 1-4), onde introduz o tema e as preocupações centrais da sua obra, logo seguida da habitual invocação (vv. 4-12, p. 210), com o pedido de inspiração às Piérides, divindades clássicas associadas ao tema; de igual modo no Brasilienses aurifodinae (vv. 5-11), é feita essa invocação para inspiração do poeta, acrescentando-lhe Febo, tradicionalmente associado ao ouro.

No Aurum, o poeta apresenta primeiro um conjunto de territórios conhecidos pela sua abundância em ouro e depois o mito que justifica a sua existência (cf. Aurum, p. 212). É possível estabelecer, neste caso, uma aproximação ao texto Brasilienses aurifodinae onde, após a proposição e invocação, o poeta evoca o mito de Júpiter e Dánae (vv. 12-44) para discorrer depois sobre as várias zonas atingidas pela chuva aurífera do pai dos deuses - completando a lista apresentada por Le Febvre, particularmente no que toca aos rios que a tradição distingue pela presença de areias auríferas (vv. 45-69).

Se para o autor do Aurum, a recens America (v. 27) é apenas uma de várias terras a merecer a sua atenção (Aurum, vv.13-31, pp. 210-211), Bartakovics, pelo contrário, considera unicamente o seu país. Numa clara declaração patriótica, o poeta revela a sua intenção de cantar as riquezas da sua terra natal, em particular a Hungria setentrional, donde provém esse ouro da Panónia cujo fulgor o tocará, antes de percorrer o mundo inteiro (Metallurgicon, p. 2, 10-12).

É também com fervor patriótico que Basílio da Gama refere a América-e o Brasil, em particular - de entre as regiões que nomeia, como a região que mais atingida foi pela divina pluviosidade, tornando-se, portanto, a mais rica em ouro (vv. 69-82).

Na Rusticatio, o foco de atenção de Landívar centra-se em exclusivo nos locais produtores de minério da América espanhola. Pretende apenas cantar as paisagens da sua terra americana, em especial a extensão das cordilheiras da Sierra Madre, desde a Nova Espanha, a sul, até ao seu extremo norte (vv. 15-23). É sob esse território que se escondem os metais preciosos, que só um esforçado trabalho poderá pôr a descoberto (cf. Rusticatio mexicana, 1. 7, vv. 1534, pp. 76-77). A Nova Espanha de Landívar corresponde maioritariamente ao México dos nossos dias, mas incluía, a sul, uma área que hoje se divide pelos territórios da Guatemala e das Honduras. À semelhança do Brasil, o grosso do ouro encontrado na América espanhola era de tipo aluvial, com veios de metal aurífero no interior das minas menos frequentes.

Independentemente da origem atribuída ao metal, a sua génese mitológica é, nalguns dos poemas em apreço, um tópico de destaque incontestável. Por exemplo, no início do Brasilienses aurifodinae, a referência à fábula de Júpiter e Dánae (vv. 12-44); o Aurum começa por recuperar o mito de que o pai dos deuses distribuiu a responsabilidade pela criação de partes da recentemente formada terra aos seus vários filhos (v. 32, p. 211). Depois de conferir o encargo pelos metais aos sete deuses planetários (v. 38, p. 211), foi a Febo, deus sol, a quem coube a criação do ouro, com o contributo do hábil fogo e do fulgor dos 
raios que tem ao seu serviço (vv. 55-61, p. 212).

Note-se, porém, que se a preparação do ouro - com a ajuda da lama e doutras matérias que o poeta deixa por nomear - pertencem ao domínio do mito, bem mais prosaicas são as actividades dos raios trabalhadores. Estes personificam verdadeiros mineiros no seu papel, recorrendo a métodos de eficácia comprovada e chegando a distribuir entre si as tarefas implicadas na mineração, por forma a potenciar uma maior produtividade. No seu trabalho, são-nos descritos divididos em distintos grupos - uns escavando fossos, ${ }^{10}$ outros canais para transporte da água, ${ }^{11}$ outros ainda galerias $-{ }^{12}$ em labor de grande exigência e dureza:

pars limumque parant, habilemque metallo

Materiam: pars multa scrobes, pars multa canales

Effodiunt: fossis fuit acta canalibus unda;

Pars molem subigunt terram, terraeque subactae

Infundunt latices: pars humida granula siccant,

Et fulvum inspirant anima propiore colorem.

Infindunt alii sulcos, perque aspera saxa

Serpere amant: lapsu sese aurea vena sequaci

Insinuat, radioque viam monstrante, pererrat

Sulcatos silices; alios juvat aurea frusta,

Flaventesque globos creta vestire tenaci;

Mollis creta fluit primo, mox igne rigescit

Durior, inclusumque recens lapis obtegit aurum.

Sunt quibus officium est tenues curvare cavernas

Fornicis in morem: quo fornice cara tueri

Pignora, quo pulchros valeant deponere foetus.

Um grupo prepara a lama, e a matéria aconselhável para o metal; um grande grupo escava trincheiras, um grande grupo canais: a água é introduzida e flui por estes canais escavados; outro grupo revolve a terra macia e adiciona-lhe o líquido quando preparado; outro grupo seca os pequenos grãos molhados e insuflalhes a cor fulva com o seu sopro particular. Outros abrem sulcos e gostam de serpentear entre as duras rochas: o veio de ouro insinua-se com um curso tenaz, mostrando o caminho do raio e vagueia por entre a pederneira aberta em sulcos; a outros agrada vestir os pedaços de ouro e as bolas amarelas com o pegajoso barro; a princípio o barro flui suavemente, mas por acção do fogo torna-se mais duro e uma nova pedra esconde o ouro encerrado. Há aqueles cujo trabalho é escavar as estreitas cavernas em forma de abóbada, sob as quais podem guardar os seus queridos tesouros, sob as quais podem dar à luz as suas bonitas crianças.

(Aurum, vv. 61-76, p. 212)

${ }^{10}$ Cf. Brasilienses aurifodinae (vv. 309-317; 832-839; 1363-1368).

${ }^{11}$ Cf. Brasilienses aurifodinae (vv. 753-788; 896-919; 964-980 e 1118-1140).

${ }^{12}$ Cf. Brasilienses aurifodinae (vv. 1141-1334). 
A dureza do trabalho mineiro é aludida no Metallurgicon através do expressão virgiliana labor improbus (Geórg., 1. vv 145ss. Cf. Metallurgicon, p. 25) e fervet opus, que também ocorrem no Aurum e na Rusticatio mexicana, ${ }^{13}$ desenhando um paralelo entre as agruras a que estão sujeitos os mineiros e as actividades dos Ciclopes na caverna visitada por Virgílio (cf. também Aurum, p. 211):

\author{
Mille lacertosi jactant sua brachia Fabri, \\ Fervet opus caeca sub nocte, ingentia pendent \\ Littora, compositis centum suffulta columnis. \\ Noctes, atque dies aeternae funibus Alni \\ Demittuntur: ...
}

Um milhar de esguios mineiros, acenando os braços, trabalham vigorosamente na treva cega, levantando enormes traves ao cimo de centenas de colunas artificiosamente erectas. Enterrados dia e noite, agrilhoados com cadeias de madeira.

(Metallurgicon, p. 42, 20-25)

Na Rusticatio mexicana, o árduo esforço dos mineiros-ciclopes também é colocado em evidência, embora neste caso a separação de tarefas, apesar de não diminuir o desgaste que caracteriza a actividade mineira, poder assegurar alguma especialização e garantir melhores lucros:
Ast ubi congeriem thesauri turba retexit,
Consistit, magnamque fodit sub colle cavernam,
Immensisque vigil sustentat culmina fulcris,
Ne collapsa ruant, pereatque oppressa juventus.
Tunc operam prudens partitur cuique Magister:
Alter enim taedas dextra, lumenque ministrat,
Alter inaccessos proscindit cuspide muros,
Et legit e muris alter salientia frusta
Secernens pingues recto discrimine cautes.
Fossor opes primum, puero praebente lucernam,
Verberat, E multis lapidem quatit ictibus unum.
Saxa gemunt intus teli contusa rigore
Totaque terribili reboat spelunca tumultu.
Ceu quondam Siculi massam Cyclopes ahenam
Aetnaeis valido tractant conamine in antris,
Concutiuntque nigras magno stridore cavernas.

${ }^{13}$ Vide ocorrências: Aurum (v. 109, p. 214) e Rusticatio mexicana (livro 8, v. 39). Basílio da Gama não associa este termo à mineração. Prefere, por exemplo, sumo labore /sumum [...] Laborem /summus labor (vv. 3, 402, 1332, respectivamente); difficili Labori /difficilis labor (vv. 561, 1153); tanti [...] labores / tantisque laboribus (vv. 133 e 1111); intensumque laborem (v. 448); assiduum Laborem (v. 939) e laborem Impensum (vv. 1148-1149). 
Mas quando a multidão desfaz o montão de tesouro, pára e escava debaixo do monte uma grande caverna, atenta sustenta os tectos com grandes pilastras, para que não se desmoronem em ruínas e pereça soterrado o mineiro. Nesse momento, o feitor, prudente, distribui a cada um a sua tarefa: um, com efeito, vigia com a mão os archotes e a luz; o outro rasga com a vara as maciças paredes; e há outro que vai recolhendo os pedaços que saltam das paredes, separando com juízo correcto os ricos escolhos.

O mineiro, à luz que lhe oferece o rapaz, castiga primeiro o veio, batendo a pedra num ponto com múltiplos golpes. As pedras gemem no interior sacudidas pelo rigor da pancada e toda a caverna ressoa com o terrível tumulto. Tal qual como os sículos Ciclopes forjam a massa de bronze com vigorosa força nos antros etneos e com grande estridência sacodem as negras cavernas.

(Rusticatio mexicana, 1. 7, vv. 112-127; p. 80)

Esta semelhança entre os fossores e os Ciclopes recorda o símile entre os escravos e os Mirmidões no Brasilienses Aurifodinae (cf. vv. 935-940):

Genus exhibet aemula nigrum
Myrmidonum, dum subterranea in horrea portat
Pars onerata cibos, Longo velut agmine facto,
Pars oneranda redit, portandumque altera pondus
Pars secat: assiduum Domino stimulante Laborem
Haud secus Afros Myrmidonas nulla otia tardant.

A raça negra mostra-se rival dos Mirmidões, enquanto faz o transporte nos armazéns subterrâneos. Uma parte deve levar os pratos, como numa comprida fileira organizada, outra parte, ao voltar para trás, deve trazê-los e a outra parte separa a quantidade que é para transportar - com um capataz que os instiga, não há nenhum momento de descanso que retarde os Mirmidões africanos no seu trabalho contínuo.

(Brasilienses aurifodinae, vv. 935-940.)

A insegurança e insalubridade das condições de trabalho nas minas, tornando os trabalhadores mais susceptíveis aos ataques das doenças e aos riscos dos acidentes, não passam sem menção. ${ }^{14}$ Bartakovics, tal como fez Le Febvre e fará Basílio da Gama, sublinha a influência maligna da atmosfera viciada pelas emanações venenosas na saúde dos mineiros (cf. Metallurgicon, pp. 10, 16-17, 42; Aurum, vv. 159-172, pp. 215-216; Brasilienses aurifodinae, vv. $1215-1221$ e $1238-1252$ ).

Também Landívar segue de perto a via do Metallurgicon, notando que os mineiros eram vulgarmente afectados por doenças do tracto respiratório,

${ }^{14}$ Cf., sobre as exigências e condicionalismos da actividade mineira, A. Russell-Wood 1989: 547-600 e também P. Bakewell 1989: 105-151. 
resultantes das elevadas concentrações de gases venenosos no interior das minas (v. Rusticatio mexicana, 1. 7, vv. 69-90, pp. 78-79), mesmo se não se alonga em detalhes acerca dos efeitos da doença - que aparece identificada como silicose no Brasilienses aurifodinae - nem indica como paliativo o trabalho por turnos, como faz Basílio da Gama (cf. Brasilienses aurifodinae, vv. 1253-1276); na Rusticatio mexicana, há apenas um caminho aberto aos mineiros para escapar a uma morte iminente e inevitável, que é a de se subtraírem rapidamente à exposição aos gases, albergando-se longe das minas (cf. Rusticatio mexicana, 1 . 7, vv. 136-150, p. 81).

Se o trabalho mineiro é geralmente descrito em termos pouco lisonjeiros, pela exigência de verdadeiros titãs para o realizar, parece que a adopção dos exemplos precoces da tecnologia mineira poderia fazer muito pela melhoria das condições de trabalho que existiam no interior das minas, aumentando a sua produtividade e o lucro consequente. Numa das mais relevantes passagens do seu texto, Bartakovics descreve vários dispositivos, numa espécie de ekphrasis técnica, cujo protótipo literário se encontra no arado mencionado por Virgílio nas Geórgicas 1. vv. 169-175. Um dos exemplos é uma avançada máquina a vapor (machina Hydraulica ignea, abenea moles), utilizada para drenar as minas das inundações a que estavam sujeitas com frequência (Metallurgicon, pp. 40-41); outro, uma bomba de ar destinada a ventilar as galerias (i.e., machina anemica, sive ventosa, cf. Metallurgicon, pp. 38-39). ${ }^{15}$

Também na Rusticatio mexicana, para além da força directa que os mineiros são obrigados a despender, para transportar o mineral aos ombros do fundo da mina, o poeta menciona a existência de escadas e o recurso a uma máquina que eleva até à superfície as sacolas de couro carregadas com o minério, movida com a ajuda de duas mulas (1. 7, v. 199). Quando era necessário fazer face aos mananciais aquáticos frequentes no interior das minas, poder-se-ia optar por várias soluções, como nos diz Landívar. Encerrar a caverna (1. 7, vv. 218-227, pp. 83-4) ou fazer uma perfuração, para que as águas saíssem por impulso próprio para o exterior (1. 7, vv. 228-235, p. 84), ou então escavar grandes fossas para reunir os caudais (1.7, vv. 236-241, p. 84). A água era extraída destas cavidades com um engenho que era colocado na abertura superior da mina: as sítulas (1. 7, v. 244), conforme lhes chama o poeta guatemalteco, que eram certamente bombas, também movidas a tracção animal; Basílio da Gama descreve pormenorizadamente também estas bombas, ao longo de 39 versos, no Brasilienses aurifodinae (cf. vv. 840-879).

Podemos afirmar que, enquanto no poema Aurum a ficção e a mitologia ocupam lugar relevante, nos restantes poemas Metallurgicon, Brasilienses aurifodinae e Rusticatio mexicana,- editados já a partir de meados de Setecentos - a ficção e a mitologia seguem a par com os avanços tecnológicos da época. Não é possível mencionar aqui, pela necessária brevidade das comunicações, o conjunto de obras de referência que, quer Bartakovics, quer Basílio da Gama,

${ }^{15}$ Muito semelhante à que é descrita por Athanasius Kircher, no livro 10 de Mundus subterraneus (Amsterdam, 1665). 
quer Landívar, citam nos seus poemas, procurando, desta forma, atribuir aos seus poemas a legitimidade da ciência da época. ${ }^{16}$

Todos os poetas evidenciam a sua preocupação com o rigor dos detalhes e a veracidade do que decidiram incluir nos seus relatos, enquanto procuram conciliar a sabedoria clássica com o emergente conhecimento científico. Em concordância com o espírito do tempo em que viveram, a sua produção literária exibe profundas preocupações de utilidade científica e prática, bem como de resistência aos testes da experiência. Estas fontes poderiam fundamentar interpretações concordantes com os objectivos de produção erudita dos autores, com o espírito de emulação das autoridades a que prestaram reconhecimento e com a intenção de firme enraizamento na cultura intelectual do humanismo jesuítico.

Em jeito de conclusão, propomos a ideia que consiste na possibilidade dos trabalhos que congregámos para esta análise poderem ser usados como ilustração do constante fascínio pelo metal amarelo que surge mesmo entre aqueles de quem menos suspeitaríamos, ao supô-los mais interessados em riquezas espirituais; que esse fascínio foi motivação para vários empreendimentos académicos por parte de alguns dos muitos escritores da Companhia de Jesus; que, em especial, nos recessos desta corporação teocrática, demonstrações de proficiência nas diversas abordagens do vil metal, desde as práticas de prospecção, mineração e utilização económica até à moral das suas transacções, fossem consideradas relevantes e dignas de investigação; e, finalmente, que mesmo na 'ciência' das minas de ouro, os Jesuítas tenham buscado destacar-se como pedagogos e educadores, tal como fizeram noutras áreas de saber.

${ }^{16}$ A já referida obra Kircher é a mais citada. Bartakovics remete para obras de história, história natural e geografia de autores clássicos, renascentistas e modernos, de que podemos destacar a enciclopédia Naturalis historia de Plínio; a História natural y moral de las Indias do jesuíta José de Acosta; a Geographica orbis notitia do jesuíta Georges Fournier; ou a Epitome rerum ungaricum do dominicano Petrus Ranzanus. No caso de Basílio da Gama, as fontes clássicas de maior relevância são Ovídio, Virgílio e Horácio, respectivamente Metamorfoses, Geórgicas e Arte Poética. Do período moderno, é possível destacar modelos como a Óptica de Newton, a enciclopédia de Chambers, os Principia de Descartes e o De Revolutionibus orbium coelestium de Copérnico, por exemplo. Cf., a este propósito, A. Mariano 2005, Vol. 1: 144-153. Quanto a Landívar, além de poetas latinos como Horácio e Lucrécio, a lista compreende outras referências como, por exemplo, Sor Juana Inés de la Cruz; William Robertson (Historia de América); Ambrosio Calepino (Diccionario de la Lengua Latina); Jacopo Facciolati (Dictionarium undecim linguarum); Francisco Hernández (Historia de las aves de Nueva España); Jacques Bomare (Dictionnaire raisonné universel d'Histoire naturelle). Cita o Journal de Trérvoux (out. 1712). Menciona também um conjunto considerável de autores e obras jesuítas coevas como por exemplo: Diego José Abad (De Deo); Francisco Xavier Alegre (Traducción de la Ilíada al latín y la Alexandriada); José de Acosta (Historia Natural y Moral de las Indias), Juan Antonio de Oviedo (Zodiacum Marianum) e Jacques Vanière (Praedium Rusticum). Por outro lado, sabe-se que eram bem conhecidas nas colónias americanas espanholas no século XVIII as obras de autores como Descartes; Newton; Leibniz; Locke; Gassendi; Voltaire; Rousseau; d'Alembert entre outros. 
Bibliografia

Peter Bakewell (1989), "Mining in Colonial Spanish America", in Leslie Bethell (ed.), The Cambridge History of Latin America, vol. 2: Colonial Latin America. Cambridge, New York, Melbourne: Cambridge University Press, 105-151.

Josephus Bartakovics (1478), Metallurgicon, sive de cultura fodinarum auri et argenti carmen. Adjectus indiculus vocabulorum quorundam ad aurariam argentariamque spectantium. Latine, bungarice et germanice. Tyrnaviae: Ex. Typ. Academicis Soc. Jesu.

Vania Pinheiro Chaves (2000), O Despertar do Génio Brasileiro: Uma Leitura de "O Uraguai" de José Basílio da Gama. Campinas, São Paulo: Editora da Unicamp.

José Basílio da Gama Brasilienses Aurifodinae Poemate Didascalico Ab Aurifodinensibus Musis depromptae, sive De Auro, ejusque extractione in Brasilia Poetica Descriptio A Josepho Basilio Gama elucubrata. additis, Et Compendiaria appendice, soluta oratione: Et curiosa quaestione de Auri genesi. Mss. privado; Roma [?], 1760-1762 [?].

Steven Harris (2000), "Mapping Jesuit Science: The Role of Travel in the Geography of Knowledge", in John W. O'Malley et al. (eds.), The Jesuits: Cultures, Sciences, and the Arts, 1540-1773. Toronto: University of Toronto Press, 228-229.

Yasmin Annabel Haskell (2003), Loyola's Bees: Ideology and Industry in Jesuit Latin Didactic Poetry. Oxford: Oxford University Press, 2003.

Andrew Laird (2006), The Epic of America: An Introduction to Rafael Landivar and the Rusticatio Mexicana, London: Duckworth.

Landívar (1782), Rusticatio mexicana, editio altera auctior, et emendatior, Bononiae: Ex Typographia S. Thomae Aquinatis.

François Antoine Le Febvre "Aurum" (Paris, 1703) in François Oudin, SJ, Poemata didascalica nunc primum vel edita vel collecta studiis Fr. Oudin, Vol. 1. Parisiis: Petrum Aegidium le Mercier, 1749, pp. 210-223.

Serafim Leite História da Companbia de Jesus no Brasil, 10 vols. Lisboa: Livraria Portugália; Rio de Janeiro: Civilização Brasileira, 1938-1950.

Alexandra de Brito Mariano (2005), Brasilienses aurifodinae. O ouro e a literatura didáctica no Brasil Setecentista, 2 vols. [Tese de doutoramento, Universidade do Algarve].

A.J. R. Russell-Wood (1989), "Colonial Brazil: The Gold Cycle, c. 1690-1750" in Leslie Bethell (ed.), The Cambridge History of Latin America, vol. 2: Colonial Latin America. Cambridge, New York, Melbourne: Cambridge University Press, 547-600.

Carlos Sommervogel et al. (eds.), Bibliothéque de la Compagnie de Jésus, 12 vols.. Brussels: Oscar Schepens; Paris: Alphonse Picard, 1890-1932.

Françoise Waquet (2002), Latin or the Empire of a Sign: From the Sixteenth to the Twentieth Centuries. London \& New York: Verso. 
(Página deixada propositadamente em branco) 
(Página deixada propositadamente em branco) 
V - Temas de RecepÇão 
(Página deixada propositadamente em branco) 


\title{
O ESPACO FÍSICO COMO ALEGORIA DA TRAGÉDIA HUMANA. CONCEPCÃO DO ESPACO DRAMÁTICO NA TRILOGIA DE ÉDIPO DE J. DE ĆASTRO OSÓRIO
}

\author{
Ália Rosa C. Rodrigues \\ Universidade de Coimbra \\ alia.classicas@gmail.com
}

\begin{abstract}
Here is a strong and proud city. Here is the same city, but destroyed and infertile. Its flights of steps first dignify the hero, then shove him to his downfall. At the end, these stairs lead the hero to the highest level, the divine, which belongs to none other than Man, to the one that once deciphered the Sphinx. On the horizon, there is a mountain that casts shade upon the city and, although distant, it is always dreadfully present. These are some of elements that build the scenario of the dramatic poem Oedipus Trilogy from João de Castro Osório, a poet, essayist, literary critic and dramatist situated, in the Lusitanian tradition of the Neo-romantic aesthetic. This article focuses on the construction of the mythical place of Thebes as well as on the elements that symbolize and embody the implicit meanings of the myth. Therefore, it is intended to illustrate how the construction of the scenario corresponds to the concept, both in space and time, of the tragic.
\end{abstract}

Keywords: hero, myth, Neo-romantism, Nietzsche, Oedipus, reception, Superman, tragedy, trilogy.

Palavras-chave: herói, mito, Neo-romantismo, Nietzsche, Édipo, recepção, super-homem, tragédia, trilogia.

Num tempo de provação, num tempo de cegueira, num tempo de trevas, renasce novamente a Esfinge maldita, a mesma que outrora desafiou Édipo em Tebas. É este o tempo que gera profetas, heróis, deuses. Do meio da bruma surge Édipo transfigurado pelo tempo, pela espera, pela estética do seu criador, João de Castro Osório, paladino do novo caminho da claridade, do heroísmo e de um "Novo Humanismo"1 aos leitores coevos.

Poeta, ensaísta, crítico literário e dramaturgo, João de Castro Osório distingue-se, do ponto de vista ideológico, por abraçar o programa do

${ }^{1}$ Cf. "Nota Crítica" de João de Castro Osório (1954) 213-215. J.C. Osório dirigiu a revista Descobrimento (1931-32), que apesar da sua efemeridade - saíram apenas sete números - defendia uma nova civilização humanista. Sobre o tema do "Novo Humanismo" em J. C. Osório, veja-se ainda D. I. Cruz s. d.: 30-32 e J. B. Chorão 2001: 75-80 
Nacionalismo Lusitano, bem como o ideário sidonista. ${ }^{2}$ No panorama literário, situamo-lo no neo-romantismo, na corrente lusitanista que se propunha “reaportuguesar Portugal”. Apologista acérrimo da heroicidade histórica da pátria, sublimador das manifestações artísticas da raça portuguesa, legounos o primeiro testemunho deste pensamento no Manifesto Nacionalista (1919).

Escrita por volta do final da II guerra, a Trilogia de Édipo, a peça que aqui nos ocupa, é publicada dez anos após a sua escrita, no ano de 1954. Três anos depois é publicado o "poema dramático" de Natália Correia intitulado $O$ Progresso de Édipo e finalmente, em 1960, a obra-prima, António MarinheiroO Édipo de Alfama, de Bernardo Santareno. Porém, o herói tebano da Trilogia de Édipo é bem diferente dos tratamentos míticos posteriores, marcados pela influência freudiana e surrealista. ${ }^{3}$

A peça que aqui nos ocupa distingue-se dos subsequentes tratamentos tanto do ponto de vista formal, como narrativo e mítico. A estrutura trilógica do drama ${ }^{4}$ é o aspecto que distingue verdadeiramente a obra, pois recupera uma forma de dizer o trágico, que remonta aos antigos trágicos ${ }^{5}$, tendo sido reutilizada por Wagner, na Tetralogia do Anel do Nibelungo. ${ }^{6}$ A forma coadunase bem com o tema, um hino ao heroísmo, próprio para exaltar a grandeza épica da acção humana, em perfeita harmonia com o mito, ou melhor, com este tratamento do mito tebano.

O Herói, por sua vez, é perfilado à luz do Super-Homem nietzscheano ${ }^{7}$, uma versão humana de Prometeu. O poema dramático de J. C. Osório é composto pelas tragédias a Esfinge, Jocasta e Antígona; enquanto que a primeira não se baseou, segundo o próprio, em nenhum modelo, já as outras vão beber, embora com consideráveis desvios, às narrativas do ciclo de Tebas, que contavam já "com numerosas traduções modernas." (p. 212).

${ }^{2} \mathrm{Na}$ sua actividade de doutrinador político, publicou o Manifesto Nacionalista (1919), Revolução Nacionalista (1922). Quanto a obras mais directamente relacionadas com o Sidonismo, legou-nos o prefácio da compilação dos "discursos e alocuções" de Sidónio Pais, intitulado Sidónio Pais e o messianismo dictatorial in Um Ano de Ditadura. Lisboa 1924.

3 Em "Nota Crítica”, J. C. Osório manifesta o seu desagrado pelas modernas interpretações do mito Édipo, classificando-as de "deturpantes e falsas" (p. 212).

${ }^{4}$ Além da obra que aqui nos ocupa, escreveu ainda mais que apresentam este tipo de construção, nomeadamente a e Tetralogia do Príncipe Imaginário (1940-41) e Trilogia de Tróia (1999).

${ }^{5}$ É expressiva a opinião de J.P. Serra 2006: 90: "Os séculos XIX e XX não reconheceram nesse tipo de poesia grandiloquente e a aristocrática o meio para expressarem a sua "alma”, o seu sentir e o seu pensar."

${ }^{6}$ Sobre a recepção de Richard Wagner em Portugal, veja-se o capítulo de V. Simões 1911: 225-251, o artigo de J. de F. Branco 1976: 54-59, bem como o estudo de M. V. de Carvalho, Pensar é morrer ou o Teatro de São Carlos na mudança de sistemas sociocomunicativas desde os fins do séc. XVIII aos nossos dias. Lisboa 1993.

7 Para conhecer uma visão mais objectiva da recepção das ideias do filósofo de Röcken em Portugal, veja-se o exaustivo estudo de A. E. Monteiro (2000), bem como o capítulo "Sobre certa recepção literária de Nietzsche em Portugal” in J. C. S. Pereira 1979: 33-40 e o artigo de J. Ferreira 1996: 98-128. 
O cenário onde terá lugar a acção das três tragédias configura desde logo a dimensão trágica da peça, como se a acção das personagens estivesse já implícita e inscrita no próprio espaço:

"A cena principal é na Acrópole, onde se vêem o palácio dos Reis e um Templo, em face do qual se eleva uma ara, encimada por uma estátua". (p.9)

Até aqui estamos a desenhar a Tebas sofocliana, um espaço elevado do ponto de vista físico, moral e ético, marcado por uma aura de excepcionalidade que faz adivinhar o mesmo em relação ao destino dos personagens que ali se confrontarem.

Contudo, embora o autor tenha procurado seguir a narrativa mítica na sua versão cristalizada, acaba por advertir o leitor mais adiante:

"Só o assunto lhes é comum, (...) as lendas do mito tebano foram, por mim, recriadas (...) também com a independência precisa para que pudessem representar em figuras vivas um pensamento dramático muito diverso". (p. 210)

De facto, na Tebas recriada, ergue-se, imponente, uma escadaria:

"À esquerda, com o acesso defendido, uma escadaria larga para a cintura exterior das muralhas e para uma das portas da Cidade, flanqueada por duas torres. A parte mais alta das torres e a grande porta das muralhas sobem quase ao nivel da cidadela". (p.9)

Severamente defendida por altas muralhas que desencorajam qualquer ofensiva exterior, esta protecção confere ao povo de Tebas uma forte sensação de estabilidade. Ergue-se, porém, uma montanha:

"Vê-se, por cima do casario e das muralhas, a planicie e, para além, a grande montanha escalvada que fecha o horizonte, ameaçadora". (p. 9)

A montanha constitui assim um elemento natural opressor não só para a natureza como para o homem que a vê e sente como "ameaçadora", como que uma limitação cósmica em relação à acção daquela comunidade:

"A cena deve representar bem o coração de uma Cidade, forte e orgulhosa, dos Homens, amuralhada contra os inimigos e as forças exteriores e onde resiste o seu poder e força religiosa, mas de onde, como de um terraço mais alto, melhor se vê o horizonte hostil que a rodeia". (p.9)

Assim, um cenário com estas dimensões reduz o homem à sua insignificância, mas convida-o também ao heroísmo, criando essa mesma expectativa no próprio leitor. Porém, qualquer acção que ultrapasse a mediocridade humana conduz à perdição e lá está o profundo abismo junto à acrópole para o lembrar. 
Esta paisagem corresponde portanto ao horizonte físico da Cidade, "mirante dos Homens sobre o Mundo", e configura, ao mesmo tempo, o horizonte psicológico da Cidade, isto é, vem provar a insuficiência da acção humana e a sua ineficácia para resistir à fatalidade, pois é justamente "o terraço mais alto" que permite ver a hostilidade do horizonte. Tebas representa uma comunidade "forte e orgulhosa", com esferas de poder bem definidas, um microcosmos em tensão, numa espera contínua da ruptura derradeira.

A primeira peça, $A$ Esfinge, abre entre a luz e as trevas, o mesmo é dizer, entre a esperança da prosperidade e o início do terror esfíngico:

"Vai clareando a manhã: todo róseo o céu, a oriente.

Mas sombria, ainda a montanha ao fundo". (p. 13)

Porém, a Luz cede às Trevas, a grande Sombra avança sobre a Cidade e posto que o tributo anual tem de ser prestado à Esfinge, terá de ser derramado o sangue das virgens oferecidas em sacrifício. Reconhecemos, neste avanço e recuo da Luz e da Sombra, a presença da dualidade sofocliana luz/trevas, ${ }^{8}$ a primeira como caminho da verdade e do auto-conhecimento e a segunda como extensão figurativa da cegueira inerente à condição humana. As trevas assumem, porém, um significado mais profundo, pois parecem configurar a alegoria do medo como princípio da cegueira e obediência fundamentalista às divindades nocturnas. ${ }^{9}$

Eis a paisagem da versão lusitana do mito edipidiano: a Esfinge, a montanha e a escadaria, elementos que constroem mecanicamente uma simbologia própria, a partir do seu enquadramento na aç̧ão dramática. $\mathrm{Na}$ verdade, a existência e insistência destes elementos acabam por densificar a significação de cada momento, abrindo caminho para o clímax final, quer seja de júbilo, como é o caso da primeira e da terceira tragédia, quer seja de lamento, como é o caso da tragédia Jocasta, motivado pela anagnórise e pela partida de Édipo.

O elemento mais significativo deste cenário é, sem dúvida, a escadaria larga que se estende desde a Acrópole até à cintura exterior das muralhas. Referida sempre nos momentos mais reveladores das tragédias, ora a elevar ora a rebaixar o herói: cada subida ou descida tem sempre um efeito terrível no herói e consequentemente na vida de toda a Cidade. Quando Édipo, sozinho, vai desafiar a Esfinge,

"Afasta-se, pela escadaria, para as muralhas. (...) Um silêncio longo de espanto. E no silêncio dos homens que esperam ecoa a voz de Édipo que, ao franquear a porta, se vira e grita ainda a sua força”. (p. 48)

Triunfante e sozinho, o herói sobe a escadaria ao som de gritos de louvor e de júbilo proclamados por toda a Cidade. (Cf. pp. 56, 57, 58)

\footnotetext{
${ }^{8}$ Sobre a simbologia da dicotomia luz/trevas no teatro sofocliano, veja-se o estudo de M.C. Fialho 1992.

${ }^{9}$ Cf. J. C. Osório 1954: 196, 23, 34, 40, 154.
} 
"O cortejo triunfal vem subindo as escadarias. (...)

Édipo chegou ao alto da escadaria". (p. 57-58)

A subida do Herói é gradualmente descrita, representando a apoteótica ascensão de um homem estrangeiro e desconhecido pela população, que, em delírio exultante, deposita nele a responsabilidade do presente e a esperança de um futuro próspero. Contudo, para subir, triunfante e sozinho, a escadaria, o herói teve primeiro de a descer e pôr à prova os limites da sua humanidade, a mesma atitude que distingue afinal os entes superiores. A multidão - qual massa informe - molda-se ao bic et hunc, ora elevando-se ora rebaixando-se com o Herói, o único com auto-determinação para ser o seu próprio destino.

O Herói, ao contrário da Cidade, não presta obediência às divindades das Trevas, e por isso não vê a Sombra, metáfora de medo, pois Édipo conhece apenas a sua divindade, intrínseca à geração humana:

"A maior Divindade vive nos homens. É a força divina que em mim se afrma e quer combater". (p. 45)

$\mathrm{Na}$ segunda tragédia, depois da anagnórise, Édipo, já cego, volta a descer voluntariamente a escadaria. Note-se o peso e o sofrimento desta descrição:

"Antígona, com a mão de Édipo sobre um dos ombros, comę̧a a descer a escadaria da Cidade. (...) Édipo, apoiado em Antígona vai descendo (...)”. (p. 127)

Esta descida contrasta com a primeira vez que Édipo desce a escadaria para, sozinho, desafiar o Monstro. O Herói desafia novamente a Esfinge, o autoconhecimento, mas agora com outros olhos, com outra lucidez. Torna-se ele próprio a Esfinge, pois é ele que agora questiona:

"Horror! Horror! Horror! A Esfinge vive... O monstro vive dentro de mim. Precipitou-se no meu peito, quando a venci? Salvei a Cidade, para me perder?" (p. 106)

$\mathrm{Na}$ última tragédia, o herói de outrora surge-nos agora transfigurado pelo tempo, pelo sofrimento, mas mais iluminado e elucidado pela carência de visão fisica que lhe abriu os olhos para a Verdade. Note-se mais uma vez a descrição da marcha de Édipo, pesada, lenta e solitária:

"A multidão solta gritos de adoração, de espanto e de terror sagrado, enquanto Édipo lentamente sobe até à Acrópole de Tebas, ajoujado com o peso do filho morto". (p. 191)

$\mathrm{Na}$ verdade, na paisagem física da trilogia está já inscrito o estigma da queda do Herói, espelho do Homem, que configura a dimensão do trágico. $\mathrm{O}$ cenário acaba por corporizar o sentido mais profundo da peça, o problema do 
determinismo da tragédia grega, o fatalismo, conciliado com a liberdade cristã ou o heroísmo. Por isso, mais do que uma alegoria da queda, a paisagem mítica relata a ascensão do Homem, apenas concebível após a queda. A ostentação desta afirmação afasta este tratamento da versão sofocliana, quando recordamos a reflexão final do coro no IV Estásimo:

\author{
"Ó gerações dos mortais, \\ Como a vossa vida ao nada \\ Se me iguala!"10. (v.1185)
}

$\mathrm{Na}$ verdade, J. C. Osório procurou recriar "as lendas sem as trair nem amesquinhar, mas sobre os seus dados essenciais inventando um novo Mito de Édipo.”(p.214) A mitogénese era, de facto, apanágio da geração neo-romântica, peculiar à estética do lusitanismo, pois urgia buscar um poder místico que unificasse a nação. ${ }^{11}$

A analogia entre o perfil deste Herói e uma certa recepção do sobre-humano proclamado pelo iluminado Zaratrusta, é corporizada na figura de Édipo, que, segundo o autor, apresenta uma grandeza já devidamente reconhecida pela tradição épica e dramática ${ }^{12}$.

J.C. Osório mais não desejava do que "exprimir alguma coisa da tragédia e heroísmo da humana condição.”(p. 218) A queda, neste ponto de vista, consiste apenas num caminho, num estado transitório, numa fatalidade cósmica que tem de ser superada para que o Homem possa de novo subir essa escadaria, vitorioso, depurado de qualquer mancha. Este Homem já foi miticamente representado por Édipo, o que distinguiu como paradigma ideal para configurar a alegoria da tragédia humana numa paisagem impossível:

\title{
"Venceu o Homem, Édipo venceu a Esfinge". (p. 58)
}

Distante já da concepção trágica sofocliana, este Édipo tem tal autodeterminação que toca mesmo a impiedade religiosa.

"Mesmo que sejam adversos, os Destinos não podem obrigar-me a cometer o que não quero". (p. 81)

Este herói é arauto do caminho de um dia de luz, do Novo-Humanismo e para este, a divindade não é omnisciente, não é, mas habita já no Homem ${ }^{13}$. A

10 Tradução de M.C. Fialho 1995: 136.

${ }^{11}$ António Sardinha defende uma adaptação nacional da teoria de G. Sorel (1847-1922) da noção de mitogénese, quando este filósofo atribui um valor social e nacional ao mito. Vide idem (1952), Glossário dos Tempos, p. 115-116 Além deste, também é considerada a visão do sociólogo V.Pareto (1848-1923) que reconhece no mito um valor sinérgico e catalíctico nas sociedades.

${ }^{12}$ Vide "Nota Crítica", pp. 210-211.

${ }^{13}$ Cf. J. C. Osório 1954: 70, 106, 113, 125. 
divindade é agora uma presença contínua, sem ser, ao mesmo tempo, mortal, pois não se extingue com o corpo, mas está acesa em toda a criatura humana e revelase sempre que o Homem se supera. O espaço dramático da Trilogia de Édipo reflecte o tempo psicológico do autor, um tempo de provação e de cegueira que gera o novo Homem, dito através de uma paisagem impossível e épica.

\section{Bibliografia}

\section{Edições}

M. C. Fialho ( $\left.{ }^{4} 1995\right)$, Sófocles. Rei Édipo. Lisboa.

A. Margarido (2004), Nietzsche. Assim falava Zaratustra. Lisboa.

J. de C. Osório (r 954), A Trilogia de Édipo. Lisboa.

\section{Estudos}

J. de F. Branco (1976), "Como e quanto se tem conhecido Wagner em Portugal?”, Colóquio/Artes 27 54-59.

J. B. Chorão (2001), “O drama de João de Castro Osório”, Foro das Letras 4/5 75-80.

D. I. CRuz (s.d.), "Neo-classismo na obra de João de Castro Osório" in Introdução ao Teatro Português do séc. XX. Lisboa.

J. Ferreira (i996), "Os veios nietzscheanos da modernidade literária portuguesa" in A Questão do Modernismo na Literatura Portuguesa. Brasília, 98-128.

M. C. Fialho (1992), Luz e Trevas no Teatro de Sófocles. Coimbra ( ( 993), "Rei Édipo: tragédia e paradigma. Algumas etapas na história da sua recepção", in As Linguas Clássicas. Investigação. Ensino. Coimbra 67-82

(2006), "A Trilogia de Édipo de João Castro Osório", Humanitas 58 481-494.

A. E. Monteiro (i 988), A recepção da obra de Friedrich Nietzsche na vida intelectual portuguesa: 1892-1939. Porto.

J. C. S. Pereira (1979), Do Fim-de-Século ao Tempo de Orfeu. Coimbra.

(1999), O neo-romantismo na poesia portuguesa: 1900-1925. Diss. Doutoramento Coimbra.

A. Sardinha (i 9i 5), O Valor da Raça. Introdução a uma Campanha Nacional. Lisboa.

J. P. Serra (2006), Pensar o Trágico. Lisboa.

V. Simões (1909) “A nova geração do Neo-Lusitanismo", Serões 51 201-211. (1911), A Nova Geração: estudo sobre as tendencias actuaes da litteratura portuguesa. Coimbra. 
(Página deixada propositadamente em branco) 


\title{
RELEITURAS DE UM PASSADO GREGO A TRAGÉDIA OEDIPVS TYRANNOS DE SÓFOCLES
}

\author{
Rogério José DE SouZA ${ }^{\mathrm{I}}$ \\ Universidade Federal Rio de Janeiro
}

\begin{abstract}
In this analysis of the tragedy Oedipus Tyrannos, by Sophocles, the concern regards the issue of how a fragment that expresses an important characteristic, not only from the Polis but also from the Archaic period, is suppressed, becoming a common pattern to the various Portuguese language translators between the period of 1765 ( the oldest version found in Rio de Janeiro) and 2001 ( the last version found at afore mentioned city). This fragment refers to the description given by Jocasta to Laius, her husband and Oedipus' father. The passage (vv 740-745) refers to the moment the protagonist (Oedipus) asks his wife (Jocasta) to describe her deceased husband, Laius. The first word she uses, marks a physical characteristic of both characters. However, all the versions analysed, when compared to the English versions, omit or modify the sense in which the term referred to was known in the archaic Greek. Thus, we aim to demonstrate the close relationship between the omission/ modification of this fragment and the construction/ re-invention of an archaic Greek that, in the past, produced a very diverse documentation; the racialization seemed not to be so determinant, although during a later period, also rich in documentation, it seems to be diffused with racialized profile.
\end{abstract}

Keywords: epistemology, Greek tragedy, re-invention.

Palavras-chave: branquitude, epistemologia, reinvenção, tragédia grega.

Um dos eixos fundamentais no qual a produção conhecimento se alicerça está fundado na classificação social da população sobre a idéia de raça, uma realidade social que permeia as dimensões mais importantes das relações sociais brasileiras. Essa racialidade compreende também um certo número de aspectos que definem seu funcionamento em relação ao conjunto da sociedade. Nesse caso, o aspecto que nos interessa na discussão desse artigo é o fenômeno da branquitude.

$\mathrm{Na}$ historiografia, a hegemonia da branquidade é resultado de um longo processo de aprendizagem que se prolonga nas várias etapas de estudo da vida universitária. O cientista em formação é efetivamente isolado de outros interesses intelectuais ou vocacionais, ficando extremante dependente dos

${ }^{1}$ Mestre em História comparada pela UFRJ e pesquisador do Laboratório de História Antiga da UFRJ. 
seus professores. $\mathrm{O}$ professor tem uma efetiva influência sobre a escolha investigativa de um pesquisador iniciante, determinando se terá ou não sucesso na vida acadêmica, chegando, até mesmo ao conceito que o indivíduo faz de si mesmo.

Este modus operandi acadêmico nos leva a fazer a seguinte pergunta: como garantir a pluralidade dos temas investigados na universidade se existe uma ausência de professores negros, sobretudo em determinados campos de conhecimento? Esta ausência teria algum impacto na epistemologia da disciplina História? De fato o pequeno número de professores e estudantes negros nos programas de pós-graduação reflete na falta de pesquisas em determinados ramos do conhecimento. Cabe ressaltar que juntando todos os professores das principais universidades brasileiras (USP, UFRJ, UNICAMP, UNB, UFRGS, UFSCAR E UFMG) teremos um grupo de cerca de 18.400 acadêmicos, a maioria doutores. Deste universo, apenas setenta são negros, e nenhum é índio (Carvalho 2007: 93). Nesse sentido, não estaremos exagerando se afirmamos que a práxis historiográfica se confundiu com a ideologia da branquitude, mesmo que o método e a teoria pareçam seguir sem sofrer interferências. A invisibilidade ou ausência das discussões da ótica brancocentrada nos currículos escolares e universitários e a reprodução, circulação e influência em variados contextos sociais e pedagógicos tem assegurado um olhar unilateral em muitos campos das ciências humanas (Rossato; Y Gesser 2001: 32).

Melissa Steyn (2004: 115) se refere a branquidade como um "constructo ideológico do projeto modernista de colonização (...) um constructo de poder: os brancos, como grupo privilegiado, tomam sua identidade como a norma e o padrão pelos quais os outros grupos são medidos”. Este conceito se implica na produção teórica acadêmica, pois a autonomia da comunidade científica não pode ser tida como algo automático. A prática historiográfica está assentada em um sistema de referências e este sistema manifesta-se enquanto uma filosofia implícita particular que se mistura ao trabalho de análise, organizando-o à sua revelia, remetendo-o à subjetividade do autor (Certeau 1982: 67).

A historiografia como atividade humana multilateral não é só um corpo de conhecimentos ou teoria,é tambémuma metodologia, uma prática, uma tradição, e contém as formas de verificação, transmissão e absorção desse conhecimento. Além disso, a historiografia é uma olhar que permite importantes correlações e possui um poder simbólico. Segundo Bourdieu (1989), o poder simbólico consiste em um poder exercido através do discurso, reconhecido pelos demais e legitimado devido à posição social de quem o profere. No entanto, somente recebe prestígio ou poder simbólico quem detém capital simbólico, ou é capaz de transformar alguma espécie de capital, como por exemplo, capital econômico, cultural ou social, em capital simbólico.

Assim na historiografia falar-se-á que a subjetividade preside a escolha do objeto, sem evocar que a priori tem-se o discurso da cultura branca ocidental como a "única e verdadeira", em que o branco é o proprietário do lugar de referência (Said 1990). Sendo assim, as escolhas interpretativas que sigam outras direções estarão sujeitas a "polícia da historiografia" e ao tribunal presidido 
por um grupo que habilita ou não um locutor ao discurso historiográfico. Mas como ter a certeza de que pesquisadores negros e indígenas estão sendo academicamente avaliados, se não temos pares nas universidades? Como captar o lugar social do branco que avalia ou produz um trabalho e mensurar os limites epistemológicos que sua obra ou avaliação pode impor?

A historiografia é uma ciência implantada no seio da sociedade e como tal inevitavelmente passível de ser permeada pela ideologia da branquidade. Segundo César Rossato e Verônica Gesser (2001: 11),

\begin{abstract}
"a Branquidade seria uma consciência silenciada ou experiência branca e pode ser definida como uma forma sócio-histórica de consciência nascida das relaçôes capitalistas e leis coloniais, hoje compreendidas como relaçôes emergentes entre grupos dominantes e subordinados. Essa branquitude como geradora de conflitos raciais demarca concepções ideológicas, práticas sociais e formação cultural, identificadas com e para brancos como de ordem branca e, por conseqüência, socialmente hegemônica".
\end{abstract}

As lutas simbólicas estão sempre presentes no cotidiano, dissimuladas, entre os que têm interesse em manter as objetivações/representações oficiais e os que pretendem transformá-las. Revisitar os mitos fundadores da cultural ocidental e rever a retórica utilizada para legitimá-los na academia, contribuindo assim para o fim da legitimidade de procedimentos preconceituosos e discriminatórios no mundo acadêmico, uma vez que muitos dos argumentos de dominação, hierarquização são buscados em um passado forjado (Hobsbawn 1997: 10).

Sabemos que a "operação historiográfica" (Certeau 1982) viabiliza sempre um novo olhar sobre a história, o que pluraliza as considerações sobre um mesmo evento, mesmo quando analisado o passado que já se sabe, ou que se passou. $\mathrm{O}$ "fazer historiográfico" carrega em si o germe de sua contínua renovação, pois está sempre em andamento, numa investigação disposta a desvelar um fato ou personagem até que ambos se revelem em seus simulacros.

Não obstante, partindo das práticas e discursos historiográficos, Certeau (1982) se propõe a pensar algumas questões. Cabe citar uma delas para enriquecer as argumentações que justificam a relevância de nossas reflexões. $\mathrm{O}$ referido autor destaca a necessidade de se historicizar a História, que implica no movimento que liga uma prática interpretativa a uma prática social, e quanto essa preocupação é útil para pensar pesquisa e pesquisador (Certeau 1982: 33). Seguindo a profilaxia certeauniana, estamos sugerindo que a produção do conhecimento é indissociável das dinâmicas da branquitude presentes em nossa sociedade e este conhecimento está cada vez mais associado a equipes, profissionais de renome, financiamentos, e privilégios e prestígios que este ou aquele estudo proporcionam.

Deste ponto de vista, sendo a branquitude uma das norteadoras silenciosas das subjetividades que intercedem na escolha do objeto e ausente do status de prestígio de que dispõem outros recortes investigativos, como aumentar as produções que privilegiem outros grupos étnico-culturais? Como 
transversalizar estudos afro-brasileiros e africanos nos diferentes recortes temporais que compõem a prática historiográfica, saindo das circunscrições temáticas a que o negro está submetido no Brasil?

No que se refere às análises sobre a historiografia antiga, entrecruzá-las com o conceito de branquidade, buscando os princípios da branquidade nos leva a uma conclusão: o conjunto de convicções sobre a "brancura" ${ }^{2} \mathrm{da}$ Grécia Clássica e a conseqüente postura dos estudos clássicos brasileiros em refutar essa discussão, serviu como referencial para inclusão desse segmento de pesquisadores em uma categoria, que se percebia a si mesmo, a parte das transformações raciais verificadas na sociedade. Parece-nos que o fato de os estudos clássicos estarem em um passado longínquo e dependerem fundamentalmente das fontes escritas, iconografias etc, fizeram com que os intelectuais desse campo de estudo se pensassem transcendentes ao mundo cotidiano. Não se verificou o entrecruzamento entre as dinâmicas raciais brasileiras e a produção do conhecimento no campo da História Antiga no Brasil.

O "simulacro da branquidade" marca esses contextos historiográficos e têm orientado de forma sub-reptícia não só as estruturas sociais, como as formas de definição do conhecimento nelas produzidas. A branquitude nesse campo da historiografia personifica-se na força política obtida no esforço discursivo de silenciar a identidade branca presente na produção do conhecimento (Ware 2004; Apple 2001), pois o imaginário social está permeado pela idéia do branco como um padrão universal, neutro e destituído de racialidade.

Como parte dos elementos que apóiam este debate, analisar-se-á tragédia de Sófocles "Édipo Rei". O momento que interessa é a passagem em que o protagonista pede a Jocasta que descreva o finado rei Laios. Transcrevo aqui os versos (740-743) de Sófocles, tal como eles aparecem em grego na referida tragédia que chegou até dias atuais.

(Édipo) Não me interrogues. Antes quero que respondas: como era Laios e quantos anos tinha então?

(Jocasta) [Ele era] negro (mélas) e há pouco seus cabelos começaram a branquear. Sua aparência não era diferente da sua.

O termo mélas, apontado por Jocasta como uma característica de Laios, e, conseqüentemente, de Édipo, vem sendo omitido no português, desde pelo menos, 1785 até 2002, conforme dissertação defendida recentemente (Souza 2007: 13-15). Analisaremos as traduções mais recentes de três importantes

\footnotetext{
${ }^{2}$ Brancura aqui entendida como uma característica fenotípica, sendo um dos elementos definidores da identidade racial branca. Esta tem influência na definição das estratégias e produção discursiva desses grupos.
} 
intelectuais brasileiros. Como iremos verificar, todos os tradutores optam pelo termo mégas, ou seja, grande ao invés de mélas, ou seja, negro.

Como fonte de consulta para averiguação do significado do termo mélas foram utilizados quatro dicionários grego-português (ver item 2 da bibliografia). Todos eles traduzem a palavra como preto, negro.

Uma tradução da Tragédia de Édipo foi proposta por Mario da Gama Kury. Este acadêmico já havia publicado (1966), em prosa, uma outra tradução. Este trabalho tem uma preocupação acadêmica. $\mathrm{O}$ autor aponta, no prefácio, a quantidade de livros consultados para a realização da obra. Convém observar que ele foi uma das maiores autoridades do país em matéria de tradução de obras da Antigüidade grega. Entretanto, em ambas as obras, o termo mélas não conhece um sentido mais próximo da versão que aqui apresentamos.

(Édipo) Não me interrogues. Antes quero que respondas: Como era Laios e quantos anos tinha então?

(Jocasta) Ele era alto seus cabelos começavam a branquear Laios tinha traços teus.

Vejamos agora as traduções de 2000 e 2001, encontradas na Biblioteca Nacional no Rio de Janeiro. A primeira delas foi feita por Cegalla (2000), a partir de consultas às obras dos helenistas italiano Bassi e francês Gergin. O referido tradutor, embora seja um importante gramático da língua portuguesa e afirme traduzir diretamente do grego, mantém o mesmo padrão. Os diálogos traduzidos em nada se diferenciam dos anteriores:

(Édipo) Não me perguntes. Dize-me, antes, que aspecto físico e que idade tinham Laios? (Jocasta) Era alto, na cabeça apontavam-lhe os primeiros cabelos brancos. Fisicamente, era bastante parecido contigo.

A segunda tradução (2001) foi produzida por Vieira Trajano, professor de Letras Clássicas da UNICAMP. Esta obra tem caráter acadêmico e foi financiada pela FAPESP com apresentação de Jacó Guisburg, especialista em estética. O interessante é que na versão grega, em anexo da edição, o autor apresenta, na própria versão grega, a palavra mégas (alto), sem registrar uma nota de pé de página que aponte as possibilidades e ambigüidades da tradução do verso em questão. O diálogo mantém-se o mesmo:

(Édipo) Pergunta-me depois! Fala de Laios. Qual seu aspecto físico? Que idade tinha? (Jocasta) De porte grande, já com os fros grisalhos, os traços deles aos teus se assemelhavam".

As traduções e interpretações consagradas à tragédia de Sófocles "Édipo Rei” aparecem a cada ano num ritmo constante. No entanto, nenhuma das traduções analisadas registra em nota de pé de página a divergência em torno da tradução do termo em questão. $\mathrm{Na}$ versão em inglês que 
utilizamos como referência uma nota assinala a dúvida (e o mal-estar) do termo mélas no verso 742 .

A supressão do referido termo evidencia as dinâmicas do aspecto racial em razão de seu próprio silêncio, relacionado, portanto, a uma identidade ideológica derivada da branquitude. O silêncio tem um significado ideológico que repousa na omissão e se impõe como uma representação totalizante, funcionando como vetor da legitimidade do discurso branco. Como nos lembra Duby (1982), "é preciso interpretar o silêncio, pois há um significado ideológico que repousa na omissão".

A branquitude distorce a compreensão do passado grego, criando um falso consenso derivado de proximidade articular a uma identidade branca. Naturaliza-se uma informação, ou seja, um grupo de intelectuais emprega e confere legitimidade às categorias que fazem com que as formas ideológicas pareçam neutras, eliminando, ou deixando de problematizar, as contradições existentes no texto (Apple 1982: 65), isto é, o aparecimento do termo mélas.

Sob está ótica, de forma consciente ou inconsciente, identidades como negro, branco, mestiço não só existem, como estão associadas a hierarquias e lugares sociais correspondentes. Assim, a temporalização cria a possibilidade de tornar coerentes relações sociais fundadas na idéia de raça quando do estudo do passado clássico. A tradução da tragédia Édipo Tirano é um indício de que a historiografia, sobretudo aquela voltada para o campo da história antiga, autoriza a supressão da diferença pela ordem, reduzindo o elemento desconhecido a um erro dos copistas ou suprimindo aquilo que foge à explicação tradicional e nela assume aspecto de estranheza.

Nesse caso, a branquitude é o lugar da produção que autoriza e legitima o texto. $\mathrm{O}$ historiador supõe um passado já dado e esse se desvenda no seu texto, conforme percebemos na escolha do termo mégas e não mélas. Naturaliza-se, assim, uma imagem extremamente simplista de uma Grécia branca e ocidental, em que estão presentes às distinções ontológicas e epistemológicas entre "civilizados" (identificados aos brancos ocidentais) e "bárbaros" (africanos, árabes, asiáticos).

Há um modus operandi da branquidade na historiografia que tem conseqüências epistemológicas caras aos grupos étnicos raciais não-brancos. Como lócus de elaboração teórico-metodológica, a branquitude aparece nãodenominada ou denominada como "normativa" e a força de sua atuação é resultado do seu próprio ocultamento (Ware 2004: 324). Nesse sentido, tendo compreendido o processo social de construção da branquitude, enquanto interdito das produções acadêmicas no campo da historiografia, estaremos aptos a produzir uma literatura mais plural e que contemple distintos grupos étnicos-raciais. 


\section{Bibliografia}

\section{Traduções Utilizadas}

D. P. Cegalla (2000), Sófocles. Édipo Rei. Coleção Clássicos Gregos. Rio de Janeiro: Difel.

M. G. Kury (1998), A Trilogia Tebana (Édipo Rei, Édipo em Colono, Antígona). Rio de Janeiro: Zahar.

Sophocles (1984), Oedipus Tyrannus. Tradução: Robert Fagles. New York: Peguin Books, vv. 740-743.

Sophocles (1994), Oedipus Tyrannus. Tradução:Hugh Lloyd-Jones. Cambridge: Harvard University Press, vv. 740-743.

Sophocles (1994), Ajax, Electra, Oedipus Tyrannus. Cambridge: Harvard University Press (Loeb Classical Library).

T. Vieira (2001), Édipo Rei de Sófocles. São Paulo: FAPESP / Perspectiva.

\section{Trabalhos Específicos}

Michel Apple (1982), Ideologia e Currículo. São Paulo: Brasiliense.

Michael Apple (2001), Políticas de direita e branquidade: a presença ausente da raça nas reformas educacionais. Revista Brasileira de Educação. Rio de Janeiro, 16 61- 67.

Maria Aparecida Silva Bento (2003), Branqueamento e branquitude no Brasil. in: Iray Carone, Maria Aparecida Silva Bento (orgs.) Psicologia social do racismo: estudos sobre a branquitude e branqueamento no Brasil. Petrópolis: Vozes, 25-57.

M. Bernal (1987), Black Athena: The Afroasiatic Roots of Classical Civilisation. New Jersey: Rutgers University Press, vol. 1.

P. Bourdieu (1989). O poder simbólico. Lisboa: DIFEL

I. Carone e M. A. S. Bento (Orgs) (2002), Psicologia Social do Racismo: estudos sobre branquitude e branqueamento no Brasil. Rio de Janeiro: Vozes.

J. J. de Carvalho (2005), Inclusão étnica e racial no Brasil: a questão das cotas no ensino superior São Paulo: Attar.

M. Certeau (1982), A Escrita da Historia. Rio de Janeiro: Forense Universitária.

Jacques D’Adesky (2001), Pluralismo Étnico e Multiculturalismo. Racismo e Anti-Racismos no Brasil. Rio de Janeiro: Pallas.

Cheikh Anta Diop (1983), "Origem dos Antigos Egípcios", in G. Mokhtar (Org.). A Africa Antiga. Volume 2. São Paulo: Ática: Paris: UNESCO, 39-70.

G. Duby (1982), Historia Social e Ideologia da Sociedade. In: J. Le Goff, J. e P. Nora, (Org.) História: Novos Problemas. Rio de Janeiro: Francisco Alves. 
Enrique Dussel (2003), "Europa, modernidad y eurocentrismo”. in: Edgardo Lander (ed.) La colonialidad del saber : eurocentrismo y ciencias sociales, perspectivas latinoamericanas. Buenos Aires: Clacso.

Marc Ferro (1983), A manipulação da bistória no ensino e nos meios de comunicação. São Paulo: IBRASA.

Henry Giroux (1999), "Por uma pedagogia e política da branquidade". Cadernos de Pesquisa. São Paulo, 107, págs. 97-132.

Antônio Sérgio Alfredo Guimarães (1999), Racismo e Anti-Racismo no Brasil. São Paulo: FAPESP / editora 34.

Stuart Hall (2003), Da Diáspora: identidades e mediaçóes culturais. Belo Horizonte: Editora UFMG.

Eric Hobsbawm e Terence Ranger (1997), A invenção das tradições. Rio de Janeiro: Paz e Terra.

J. Ki-Zerbo (Org.) (1982), Historia Geral da África: Metodologia e PréHistória da África. Volume 1. São Paulo: Ática, 21-42.

Edgardo Lander (2003), La Colonialidad Del Saber: eurocentrismo y ciências sociales, perspectivas latinoamericanas. Buenos Aires: Clacso.

Philippe Poutignat e Jocelyne Streiff-Fenart (1998). Teorias da Etnicidade. São Paulo: Ed. UNESP.

Anibal Quijano (2003), "Colonialidad del poder, eurocentrismo y América Latina” In: Edgardo Lander (Ed.), La colonialidad del saber: eurocentrismo y ciencias sociales, perspectivas latinoamericanas. Buenos Aires: Clacso.

Cesar Rossato e Verônica Gesser (2001), “A Experiência da Branquitude Diante de Conflitos Raciais: estudos de realidades brasileiras e estadunidenses" In: Eliane dos Santos Cavalleiro (Org.) Racismo e anti-racismo na educação: repensando a nossa escola. São Paulo: Summus/Selo Negro.

Edward W. Said (1990), Orientalismo: O Oriente Como Invenção do Ocidente. São Paulo: Cia. das Letras.

Rogério José Souza (2007),Tragédia "Édipo Rei" de Sófocles. O que ela tem a nos dizer sobre relaçóes raciais no campo da bistoriografia Clássica brasileira, 2007. Dissertação (Mestrado em Historia Comparada) - Programa de Pós Graduação em Historia Comparada, Universidade Federal do Rio de Janeiro, Rio de Janeiro.

J. -P. Vernant e P. Vidal-Naquet (1997), Mito e Tragédia na Grécia Antiga. São Paulo: Duas Cidades.

Vron Ware (2004), Branquidade. Rio de Janeiro: Garamond. 


\title{
UMA VELHA ÁFRICA HERÓDOTO E O ENSINO DE HISTÓRIA DA ÁFRICA
}

\author{
José Maria Gomes de Souza Neto \\ Universidade de Pernambuco
}

\begin{abstract}
In 2003, law nr. 10.639 established new directives for national Brazilian education, advocating the inclusion of the teaching of African history and Afro-Brazilian and African culture on curriculums. This proposal, made by Brazil's Ministry of Education, has a defficency: Africa and the history of its inhabitants is presented in isolation from the rest of the world. Following Ana Mónica Lopes and Luiz Arnaut's proposal, we present the teaching of ancient African history by analysing references to Africa made by Herodotus in his Historiae.
\end{abstract}

Keywords: African history, literature, teaching of History.

Palavras-chave: ensino de História, História da África, literatura.

Há poucos anos, profissionais de história brasileiros foram colocados diante do desafio de ensinar, nas escolas, história e cultura africanas. Até então, a quase totalidade dos conteúdos didáticos brasileiros seguia uma estrutura eurocêntrica, privilegiando circunstancialmente contribuições de outras histórias humanas. A Lei 10.639 estabeleceu novas diretrizes e bases para a educação nacional, incluindo no currículo oficial da rede de ensino a obrigatoriedade da temática "história e cultura afro-brasileira". O artigo 26 afirmava que tal disciplina seria ministrada "nos estabelecimentos de ensino fundamental e médio, oficiais e particulares" África e dos Africanos" estaria incluída. O Ministério da Educação justificou tal inclusão como uma forma de resgatar "historicamente a contribuição dos negros na formação da sociedade brasileira" ${ }^{2}$, e demonstrava como ao longo da história nacional os africanos e seus descendentes foram perseguidos na educação nacional, e esperava que o ensino de história e cultura af ro-brasileiras promovesse "alteração positiva na realidade vivenciada pela população negra"

O Ministério da Educação empreendeu um debate com amplos setores ("grupos do Movimento Negro, militantes individuais, Conselhos Estaduais e Municipais de Educação" ) e aproximadamente um ano depois, foi elaborado um documento contendo as diretrizes que guiariam o ensino de história

\footnotetext{
${ }^{1}$ BRASIL 2004: 35.

${ }^{2}$ Idem, p. 08.

${ }^{3}$ Ibidem.

${ }^{4}$ Ibidem, p. 10.
} 
africana e afro-brasileira. Bem mais detalhado, este documento estabelece a importância deste novo elemento curricular: "estimular a formação de valores, hábitos e comportamentos que respeitem as diferenças e as características próprias de grupos e minorias" 5 ; "a valorização da história, cultura e identidade da população afrodescendente, combatendo o racismo e a discriminação e formando "cidadãos orgulhosos de seu pertencimento étnico-racial" ${ }^{\text {. }} \mathrm{O}$ documento estabelece, inclusive, quais aspectos, ou elementos, devem ser destacados dentro do currículo do ensino da história africana e afro-brasileira, a saber: "Articulação entre passado, presente e futuro (...) experiências, construções e pensamentos produzidos em diferentes circunstâncias e realidades do povo negro"7; "História da África tratada em perspectiva positiva, não só de denúncia da miséria e discriminações"; "História da ancestralidade e religiosidade africana (...) civilizações e organizações políticas pré-coloniais"9.

Construir uma História da África não é algo simples. O historiador Joseph Ki-Zerbo, lembrou como foi difícil, para as nações recém-independentes, elaborar uma narrativa pátria: "os cursos secundários de certos países continuavam a utilizar os mesmos livros de história do tempo da colonização, livros nos quais nada se diz sobre o passado da África" ${ }^{10}$. De fato, os alunos da África colonial aprendiam os fatos, os nomes e os homens referentes às potência coloniais, e nada sobre o seu próprio passado. Continua Ki-Zerbo, a História, para os africanos, "trata-se da procura de uma identidade por meio da reunião dos elementos dispersos de uma memória coletiva" ${ }^{11}$, situação semelhante à brasileira.

A inclusão da História da África nos conteúdos didáticos merece toda nossa aprovação e representa uma excelente oportunidade para desenvolver nos alunos de história um humanismo includente, sensível às culturas e à diversidade. Há, porém, alguns aspectos que gostaríamos de chamar a atenção.

Lembremos que a "articulação entre passado, presente e futuro" era um dos pontos-chave das novas diretrizes curriculares nacionais "no âmbito de experiências, construções e pensamentos, produzidos em diferentes circunstâncias e realidades do povo negro" 12 . Na letra diretrizes, muito pouco dessa "articulação"é destacada, e muito embora o documento alerte que é necessário “evitar distorções”, da maneira como foi elaborado, são exatamente as distorções que ganham corpo. Partamos da noção de que o conhecimento histórico começa numa narrativa, "como um romance, a história seleciona, simplifica, organiza, faz com que um

\footnotetext{
${ }^{5}$ Ibidem, p. 07.

${ }^{6}$ Ibidem, p. 10.

${ }^{7}$ Ibidem, p. 20.

${ }^{8}$ Ibidem, p. 21.

${ }^{9}$ Ibidem, p. 22.

${ }^{10}$ J. Ki-Zerbo 1972: 36.

${ }^{11}$ Idem, p. 09.

${ }^{12}$ Idem, p. 20.
} 
século caiba numa página"13. Essa narrativa requer séries, comparações, dados. Não se pode fazer da história, do ensino da história, mera coleção de fatos relevantes, enumerados sem maior ligação entre si - além da sua localização geográfica ${ }^{14}$. Da maneira como foram elaboradas, as diretrizes estimulam não o conhecimento da história africana em sua complexidade, mas antes o lugar-comum da simples enumeração dos "grandes momentos" de sua experiência histórica. Senão vejamos, as diretrizes curriculares nacionais enumeram uma série de "determinações" a serem seguidas pelo ensino de História e Cultura Afro-Brasileira e Africana; seu sétimo item refere-se à "ancestralidade e religiosidade africana; aos núbios e aos egípcios, como civilizações que contribuíram decisivamente para o desenvolvimento da humanidade; às civilizações e organizações políticas précoloniais, como os reinos do Mali, do Congo e do Zimbabwe; ao tráfico e à escravidão do ponto de vista dos escravizados; ao papel de europeus, asiáticos e também de africanos no tráfico; à ocupação colonial na perspectiva dos africanos; às lutas pela independência política dos países africanos; às ações em prol da unidade africana em nossos dias ${ }^{15}$. Adiante, a oitava determinação estabelece que "o ensino de Cultura africana abrangerá: as contribuições do Egito para a ciência e filosofias ocidentais; as universidades africanas de Timbuktu,. Gao, Djene, que floresciam no século XVI"16.

A seleção apresentada pelas determinações segue um padrão civilizatório ${ }^{17}$, segundo o qual um objetivo basilar do ensino seria apresentar aos alunos os mais importantes eixos civilizacionais africanos, as grandes eras. Cinco civilizações são citadas: Egito, Núbia, Mali, Congo e Zimbabwe. Tal critério seletivo foi duvidoso, excluiu importantes civilizações, como a etíope e a swahili. Do ponto de vista geográfico, estas culturas estão afastadas entre si e só dão conta, na melhor das hipóteses, de metade do continente.

A questão temporal é igualmente relevante: do quarto milênio a.C., quando se deu a unificação do Estado egípcio, ao século XV d.C., quando se formaram os reinos do Congo, culturas distando entre si milhares de anos. Atentemos a oitava determinação: sozinha, ela é uma prova do anacronismo e da qualidade anti-histórica dessa proposta. Reúne, num mesmo item, da civilização egípcia às universidades saarianas. Muito pouco liga tais instituições de ensino islâmico do Mali, com seus marabus ao conjunto civilizatório egípcio, milhares de anos mais velho.

${ }^{13}$ P. Veyne 1998: 18.

14 "Ora, se nos limitarmos às visões da história tradicional, o que comparamos? Acontecimentos da época de Napoleão III com acontecimentos da época de Luís XIV, o que é uma heresia, um anacronismo". F. Braudel 1989: 60.

15 BRASIL 2004: 22.

167 2004: 22.

${ }^{17}$ Cabe, aqui, uma pequena discussão sobre o conceito de civilização. Longe de ser um estabelecido, civilização possui muitas acepções possíveis. De acordo com o modelo proposto pelas diretrizes, é apropriada a definição proposta por Francis Wolff, o "segundo sentido" da civilização: "as ciências, as letras e as artes, em suma, o patrimônio mais elevado de uma sociedade”. In A. Novaes 2004: 22. 
Todas essas falhas são relevantes, importantes. Tornam-se, porém, pecados veniais quando confrontadas com o que consideramos o maior engano dessa proposta de ensino: a mera enumeração de civilizações. Fernand Braudel nos ensinou que "as civilizações são continuidades"18. Elas são diálogos. Nem sempre agradáveis ou pacíficos. Chocam-se, confrontam-se, concertam-se, tomam elementos emprestados de outras culturas, ao mesmo tempo em que também cedem aspectos seus a outrem, "um constante vaivém" ${ }^{19}$. Nesse sentido, seria fundamental que o ensino de história da África, mesmo privilegiando as civilizações, tentasse ao máximo salientar as ligações econômicas, políticas e culturais que tais grupos humanos estabeleceram entre si e com os demais eixos civilizatórios que os cercavam. Ensinar, sim, a Núbia, tanto em suas particularidades quanto em seu contato com o Egito e a Etiópia e Roma e o Império Bizantino. $\mathrm{E}$ assim por diante. Uma vez seguida à risca, porém, a proposta do Ministério da Educação seria apresentada aos alunos uma história da África estática, formada por grupos estanques, sem qualquer contato entre si.

O modelo de ensino de História da África padece do mesmo erro do ensino da História Antiga como um todo: da maneira como está colocado, parece que a Antiguidade é formada por civilizações estanques, onde os egípcios e mesopotâmicos nunca se encontram e toda a Antiguidade Oriental se encerra com o início história grega, que por sua vez deixa de existir após os romanos.

Acreditamos que o ensino de História da África deve estar integrado aos temas a ela relacionados, para sua melhor compreensão e para a construção de um conhecimento processual, orgânico. Desta feita, a história africana deve estar presente em sala de aula desde a Idade Antiga: as relações do Egito com a Núbia; a exploração das rotas de comércio que abasteciam os mercados tebanos e menfitas e mais além; a formação dos primeiros Estados na Núbia (Kush, Méroe, Nobatia); as relações dessas regiões mais ao norte com as demais civilizações e impérios antigos (Pérsia, Roma, Bizâncio) e assim por diante. A Antiga história africana é parte essencial da herança cultural daquele continente, mas tem sido relegada a uma não-existência nas escolas. Sua apresentação, certamente permitiria o melhor conhecimento das civilizações e organizações políticas e sociais africanas pré-coloniais e, também, uma melhor visualização das complexas relações inter-civilizacionais existentes no mundo antigo.

O ensino de história da África seria inserido, portanto, dentro do desafio maior de "inserir o estuda da Antigüidade na realidade brasileira" ${ }^{20}$ o qual é ainda marcado primordialmente por um viés eurocêntrico, cabendo à civilização greco-romana o grande foco da abordagem e aos demais povos da Antiguidade um papel coadjuvante. Egípcios e mesopotâmicos eram despojados de suas criações mais relevantes e apenas lhe era conferida uma primazia na criação da

\footnotetext{
${ }^{18}$ F. Braudel 2004: 45.

${ }^{19}$ Idem, p. 48.

${ }^{20}$ L. Karnal 2005: 97.
} 
civilização, algo primitivo se comparado, na perspectiva dos escritores de então, com os feitos helênicos e latinos. Aos hebreus, cabia a dúbia "honra" de meros antecessores do cristianismo. Quanto à África, nada se dizia.

As novas propostas parao ensino da história antiga prevêem "o relacionamento entre a Antigüidade e o mundo contemporâneo em que viemos (...) e as novas possibilidades analíticas dependem, em última instância, da ativação da capacidade de reflexão do aluno, diante da diversidade de interpretações e do aguçamento de sua curiosidade intelectual" ${ }^{21}$. A história da África antiga está absolutamente integrada nessa perspectiva. Se a nossa cultura pós-moderna é global, se quer global, includente, por que não começar com a Antiguidade, uma das primeiras disciplinas lecionadas nos cursos de história? A interação dos povos africanos com a Antiguidade é um rico momento para esta análise. Ao invés de repartirmos o conhecimento dos alunos em categorias estanques ("Antiguidade Oriental" e "Antiguidade Clássica") melhor seria usarmos a definição braudeliana, onde o espaço mediterrânico era um diálogo "dos espaços sólidos e dos espaços líquidos (...) uma série de casamentos entre uma civilização litorânea e civilizações interiores" ${ }^{22}$. Neste diálogo, também a África se inseria. Não como região periférica e simples fornecedora de escravos, mas como co-participante de alguns momentos daquela longa história.

Nesse contexto de integração, a utilização da obra de Heródoto, as Histórias, apresenta um excelente efeito. Como colocou Calvino (2007), "a escola deve fazer com que você conheça bem ou mal um certo número de clássicos dentre os quais (ou em relação aos quais) você poderá depois reconhecer os 'seus' clássicos. A escola é obrigada a dar-lhe instrumentos para efetuar uma opção"23. Há muito que a leitura dos clássicos está a se afastar do estudante brasileiro. Particularmente aqueles produzidos na Antiguidade, os quais, quando muito, são mencionados superficialmente em sala de aula. Tais leituras foram progressivamente abandonadas, e tal movimento provocou, certamente, um déficit no conhecimento do mundo antigo.

Defendemos com veemência o retorno dos clássicos à sala de aula, não como objeto de reverência, como marcos amarelecidos de uma cultura pretérita, mas sim como portadores da informação, do encantamento e da atração que eles são capazes de fornecer. No texto herodotiano, por exemplo, o Thôma, o maravilhoso, é um elemento sempre presente, mas em especial "quando trata de países, costumes, monumentos e comportamentos. Hartog mostra como thôma está diretamente ligado ao topos da narrativa etnográfica" ${ }^{24}$. Ora, tais descrições criam ótimos momentos para a discussão da África em sala de aula.

Lopes e Arnaut (2005) propugnam a utilização das fontes clássicas para a compreensão da África, "os pesquisadores que ainda se debruçam sobre o

\footnotetext{
${ }^{21}$ Idem, p. 99.

${ }^{22}$ L. Febvre 2004: 74.

${ }^{23}$ I. Calvino 2007: 13.

${ }^{24}$ C. Morais 2004: 29.
} 
período clássico não têm muito interesse em extrair dos antigos manuscritos referências a respeito da África" 25 . Tal proposição pode ser estendida para a utilização dos textos em sala de aula. Longe de apresentarmos um continente africano isolado, ensimesmado, quase autista, mostramos uma região vibrante, inserida nos contextos históricos do seu tempo e em diálogo (num sentido braudeliano) com o mundo que a cercava. A terra dos deuses homéricos, de homens "com o corpo impregnado do perfume da violeta e mais lustrosos do que se o houvessem friccionado com óleo" 26 . Com tal riqueza descritiva, o professor poderá discutir com os seus alunos aspectos variados de como os gregos viam os africanos, e de como estes últimos se apresentavam para o mundo.

\section{Bibliografia}

BRASIL. Ministério da Educação (2004). Diretrizes curriculares nacionais para a educação das relaçôes étnico-raciais e para o ensino de História e cultura afrobrasileira e africana. Brasília.

F. Braudel (2004), Gramática das civilizações. São Paulo.

F. Braudel (1989), Uma lição de história. Rio de Janeiro.

I. Calvino (2007), Por que ler os clássicos. São Paulo.

L. Febvre (2004), A Europa: gênese de uma civilização. Bauru.

Heródoto $\left({ }^{2} 2001\right)$, História. São Paulo.

L. Karnal (Coord.) (2005), História na sala de aula: conceitos, práticas e propostas. São Paulo.

J. Ki-Zerbo (1972), História da África Negra. Lisboa.

A. Lopes; L. Arnaut (2005), História da África: uma introdução. Belo Horizonte.

C. Morais (2004), Maravilhas do mundo antigo: Heródoto, pai da história? Belo Horizonte.

A. Novaes (Coord.) (2004), Civilização e barbárie. São Paulo.

P. Veyne (1998), Como se escreve a história e Foucault revoluciona a história. Brasília.

\footnotetext{
${ }^{25}$ A. Lopes; L. Arnaut 2005: 13 - 14.

${ }^{26}$ Heródoto 2001: 332.
} 


\title{
ELABORAC̃̃O DA LUZ NO ESPACCO ENTRE A IGREJA VISÍVEL E INVISÍVEL NO PENSẢMENTO DE KANT AS RAÍZES PLATÓNICAS E UTÓPICAS DO MODELO ORIGINAL
}

\section{Giovanni Panno}

\begin{abstract}
In the Religion in the limits of the Simple Reason the kingdom of purpose is the realisation of an ethical/political way open to the one, who achieves to take over his own too-humanity. This happens when the one imitates a model inscribed in the ontological structure of his soul (Urbild) - in this case for Kant's text this model is Christus (Vorbild) - , at the same time the one participates in the movement of the invisible church, this bypassing the visible church.

This space corresponds to the production of politics and realize the overcoming of politics in the politics. In this space religion becomes unnecessary because of her cristallized exterior bond.

The kantian kingdom of purposes has a common foundation in the idea of Good as epekeina tes ousias, beyond the Being, as in Plato's political philosophy, in Moro, Campanella and Bacon utopical projects. The aim of this paper is to show that the en-lighting production of moral, political and religious order in Kants project of a new religion is near to the platonical movement of a principle, which must not be resolved in his principiated. The mediation of the figure Christus' shows the same dialectic of platonic ideas as production of light.
\end{abstract}

Keywords: imagination, Kant, political theology, religion.

Palavras-chave: imaginação, Kant, religião, teologia política.

Erst der Messias selbst vollendet alles historische Geschehen, und zwar in dem Sinne, daß er dessen Beziehung auf das Messianische selbst erlöst, vollendet, schafft ${ }^{1}$.

\section{Utopia e simbolo}

La filosofia politica kantiana non offre il modello di una città, né sembra affrontare un progetto che condensi in uno spazio immaginato e immaginario gli esiti per la praxis del suo pensiero. Non vi sono, insomma, né un Leviatano né una Nerw Atlantis o una Città del sole, in cui gli elementi più chiaramente legati alla filosofia pratica/politica e alla filosofia della storia trovino condensazione.

\footnotetext{
1 «Solo il Messia stesso compie tutto l'accadere storico, e più precisamente nel senso che egli stesso ne redime, compie e crea la relazione con il messianico stesso» (trad. mia).W. Benjamin (1977), “Theologisch-politisches Fragment”, 1974: 203 - 4.
} 
Eppure nel loro complesso la Kritik der praktischen Vernunft, la Rechtslehre nella prima parte della Metaphysik der Sitten e i testi legati alla filosofia della storia offrono un quadro unitario di cui si vuole qui cogliere il precipitato nel testo della Religion innerhalb der Grenzen der bloßen Vernunft. Il luogo-non luogo in cui si realizza la comunicazione politica è infatti legato all'orizzonte pratico e al contempo religioso, quando si voglia spogliare quest'ultimo della connotazione istituzionale. Per questo motivo l'immagine che voglio off rire dello spazio politico in Kant è quella di una utopia fedele al disegno platonico di Callipoli, e a quanto di quelle che vengono ricordate come utopie politiche vi afferisca ${ }^{2}$. La città platonica en ourano è il luogo che produce una tensione realizzativa: non il segno di una fuga dal politico quotidiano, ma la spinta al suo rinnovamento. Allo stesso modo nel testo della Religione di Kant vi è un luogo di tensione dell'agire pratico dell'uomo non estrinseco al dominio istituzionale, ma chiamato ad affrancarvisi. Si tratta del punto in cui la chiesa visibile viene superata dalla chiesa invisibile, da quell'utopia per eccellenza rappresentata dal dominio dello spirito, ed identificabile con un regno di Dio sulla terra redento dal suo stesso carattere religioso.

Nel presente lavoro discuto la dipendenza delle strutture della storia e della ragione tese a questo fine dallo schematismo dell'analogia, cioè dall'immaginazione capace di mediare come simbolo.

L'azione morale è, infatti, dipendente dalla fedeltà ad un modello di comportamento. È l'immaginazione che temporalizza lo Urbild da un lato e lega la contingenza dell'azione ad un noumeno, inconoscibile ma stabile, dall'altro. In questa duplice via in cui lo Urbild viene rappresentato e l'azione dell'uomo deve conformarvisi la costruzione teologico-politica kantiana sfrutta l'agathon di Repubblica per superare l'immagine secolarizzata della chiesa a lui contemporanea.

\section{Contro il mito dell'età dell'oro, il misticismo e la Schwärmerey}

Il riferimento all'ideale platonico è chiaro nella discussione riguardante la tensione alla perfezione come tensione necessaria. In una nota di Der Streit der Fakultäten Kant cita alcuni progetti utopici, l'Atlantica di Platone (il Crizia), l'Utopia di Th. More, Oceana di Harrington e la Sevarambia di Allais. L'utilizzo di queste costruzioni, però, non deve essere quello di un dolce sogno, bensì quello di un limite cui è un dovere avvicinarsi (SF A 159).

Se la storia è in progresso verso il meglio, a tale progresso «ognuno è allora chiamato dalla stessa natura a contribuire per la sua parte, secondo le sue forze» (Mutmaßlicher Anfang der Menschengeschichte, MA A27). In questo è evidente il richiamo ad una dimensione politica del divenire storico, una sorta di ta bautou

\footnotetext{
${ }^{2}$ Sottotraccia agirà qui il confronto con La città del sole di T. Campanella, la New Atlantis di F. Bacon e Utopia di T. More.
} 
prattein platonico (e aristotelico) applicato ad un luogo non geografico, ma temporale, in cui si situa la dimensione della specie.

L'ideale platonico di una respublica noumenon non è «vuota chimera» (Streit der Fakultäten, SF A155-6), ma si sovrappone e supera il politico legato al fenomeno. L'uomo stesso, infatti, realizza la propria natura nell'uscita da una dimensione solo umana, nella direzione del regno dei fini e dell'utilizzo della propria libertà.

Così come non crede agli inizi congetturali, Kant rifiuta le illusorie raffigurazioni [Schattenbild] dei poeti, il Goldenes Zeitalter dove tutto è disponibile automaton (MA A 25). Perché? Come i fantastici viaggi di Robinson mostrano, queste proiezioni della fantasia si riferiscono a desideri superflui, là dove proprio le pretese l'innocenza e la semplicità sarebbero noiose all'uomo. $\mathrm{Ma}$ vi è un elemento sotteso a questa immagine: in quanto soggetto di azione morale, il senso dell'agire umano non può che situarsi nel tempo. Per tale ragione Kant si interroga più e più volte sulla possibilità di un progresso nel campo morale all'interno dello scorrere del tempo storico, ma l'immagine ipostatizzata di un'età dell'oro deve essergli sembrata pericolosamente vicina a quella di una pena eterna descritta in Das Ende aller Dinge. Se è vero che l'uomo ha bisogno di raffigurarsi un termine alla serie di mali e beni della storia, e pensare che vi sarà un punto di uscita da questa successione, dal punto di vista dell'esperienza sensibile ed intellettuale ogni rappresentazione della fine rischia di cadere nel misticismo. L'istante che segna la fine del mondo sensibile, infatti, deve coincidere con l'inizio di quello intellegibile, e questa compresenza è fonte di difficili contraddizioni in ambito teoretico.

Dei progetti utopici vicini alla matrice platonica Kant riprende, però, e proprio nello scritto Das Ende aller Dinge, la figura di un gruppo di saggi impegnati nell'educazione del popolo. Lelemento del consesso filosofico di Repubblica e del Consiglio Notturno delle Leggi, presente ad esempio nella figura della Casa di Salomone della New Atlantis, interessa la costruzione del passaggio da chiesa visibile alla chiesa invisibile tratteggiato nella Religione. All'interno del progresso storico vi sarebbe un'avvicinamento infinito a quella saggezza divina - irraggiungibile - che è la ragion pratica come «capacità di commisurare i mezzi al fine ultimo di tutte le cose, il sommo bene» (EAD A515). I diversi progetti per rendere la religione «schietta e vigorosa» devono portare il popolo a dare ascolto «non solo agli insegnamenti devoti tradizionali, ma anche alla ragione pratica da essi illuminata».

Il cammino di questo Gemeinwesen condotto da un gruppo di saggi dovrebbe seguire l'idea, il bisogno e l'interesse «nel complesso", anche lasciando illuminare la propria ragion pratica dalle «pie dottrine», ma evitando di affidarsi alla loro autorità. Questo atteggiamento deriva in parte dal rifiuto della differenza fra governanti-governati ${ }^{3}$. Chi obbedisce alla legge dev'esserne anche legislatore: tale possibilità comporta sul piano pratico il dovere per tutti di tendere ad agire mediante concetti puri della ragione. È naturale che ognuno

\footnotetext{
${ }^{3}$ Cfr. la critica aristotelica alle Leggi in Politica 1265 b18.
} 
sarà legislatore di se stesso, nel momento in cui accetterà la massima universale - ed universalizzante - che si è imposto.

Maquestamassimanoncorrispondeadunafantasticheriadell'immaginazione senza il freno della ragion pratica, come quella che immagina l'Apocalissi giovannea. Il forte legame all'elemento filosofico del progetto teologico-politico kantiano esclude proprio la mistica come «Wiederspiel der Philosophie» ${ }^{4}$ : essa non consente alcuna dinamica di progresso verso il meglio, ma ferma in un'immagine il desiderio. In questo essa è parallela alla Schwärmerey, cioè applicazione dell'immaginazione fuori dal dominio dell'esperienza (Prolegomena § 35).

Eppure il rapporto fra immaginazione e religione è più complesso, e l'oggetto religioso sembrerebbe proprio al di fuori del dominio dell'esperienza. Se è vero che la Phantasie porta ad una sorta di "Illuminatism innerer Offenbarung", quando applicata a cose di religione e non legata a concetti della ragione (SF A 146), Kant la lega sì alla ragione, ma paradossalmente a quell'idea della ragione che indica la destinazione sovrasensibile dell'uomo, cioè l'idea di infinito 5 . L'immaginazione può concorrere, quindi, alla Aufklärung, nel superamento di quella minorità «di cui ha colpa l'uomo stesso, soprattutto in cose di religione» (Was ist Aufklärung, A 481). Ciò che rende possibile la rappresentazione di un modello da seguire, e segnatamente del modello cristologico, è lo schematismo dell'analogia proprio della Einbildungskraft.

\section{Platonismo kantiano}

Il legame della ragion pratica ad un simbolo rimanda alla fedeltà kantiana al vincolo all'idea, evidente non solo nell'uso del simbolo come esibizione indiretta di un concetto, bensì in quell'ideale regolativo che richiama il Bene platonico, nella misura e nel carattere del suo essere al di là dell'essere, epekeina tes ousias (Resp.509 b-c).

L'altro carattere platonico, la figura del gruppo di saggi, non è estrinseca all'economia del percorso kantiano, ma a sua volta è destinata ad assolversi per necessità teoretica. Se permanesse come esigenza istituzionale ripeterebbe l'elemento che Kant vuole sciogliere, quello cioè dell'autorità esterna alla ragione pura pratica. In Platone, con maggiore intensità rispetto a coloro che riprendono il suo percorso nel disegno di utopie politiche, si può leggere il tentativo di sottrarre l'elemento filosofico alla sua cristallizzazione di potere. Più importante, però, rispetto a questo elemento, e determinazione essenziale al concetto di utopia, è la ripresa kantiana dell'idea del Bene nella forma dello Höchstes Gut ${ }^{6}$. Questa operazione chiede si svincolare l'utilizzo di utopia da un'accezione di cattiva infinità. Come Endzweck aller Dinge, infatti, il Bene in

\footnotetext{
${ }^{4}$ Vorarbeit zu Jachmanns Prüfung der Kantischen Religionsphilosophie.

${ }^{5}$ Chiereghin 1991: 153.

${ }^{6}$ Per la considerazione del bene più grande come "hypotiposi simbolica" cf. Langthaler
} 1991: 383 . 
Kant è ideale regolativo che spinge l'azione fungendo da punto tensivo, come peraltro mostra il concetto di diritto nella Rechtslehre. E non è paradossale che la praticità del tu devi sia propria di un legame fra Bello e Bene, che Kant evidenzia nella Kritik der Urteilskraft (§59), e richiami il problema platonico di una comunicazione fra le idee, da un lato, ma soprattutto, dall'altro, la funzione architettonica del Bene. Esso funge da riferimento per il cammino morale dell'umanità, ma non è estraneo al cammino individuale, costituisce anzi il correlato di ciò che ogni cittadino proietta all'interno di se stesso ( $\mathrm{R}$ 174-176).

\section{Cristo come modello di mediazione interiore}

Come l'idea platonica del bene, lo Höchstes Gut ha un correlato teoretico, dalla cui esposizione si evincono alcuni caratteri propri anche dell'ambito pratico.

Nel fenomeno dell'Uomo-Dio, il vero e proprio oggetto della fede beatificante non è ciò che di lui cade sotto $i$ sensi o può essere conosciuto con esperienza; questo oggetto è piuttosto lo stesso modello originario che, insito nella nostra ragione, noi poniamo appunto alla base dell'Uomo-Dio (e ciò avviene perché costui, per quanto è possibile desumere dal suo esempio empirico, viene trovato conforme a tale modello). Perciò la fede beatificante coincide con il principio di una condotta di vita gradita a Dio. [R 174-176, 2837]

Del Noumeno si pone come centrale la mancanza di determinazione temporale (Krv B569 e B307), esso, però, così come l'idea, non è presente nella ragion pratica solo in modo anticipatorio e simbolico, perché ciò significa misconoscere proprio il ruolo hegelianamente concreto che ha il Vorbild kantiano. Esso è anche Urbild perché rimanda ad un originario che è proprio anche dell'uomo. Come l'idea del Bene, la sua rappresentazione figurale va ricomposta in interiore bomine ( $\mathrm{R}$ 79-80), in un luogo al contempo soggetto al tempo ed in grado di guardare a ciò che lo affranca da esso. Il campo noumenico dell'uomo è infatti luogo-non luogo della tensione verso la sua libertà, tensione che già la implica. Come dire: nel tempo l'uomo si svincola dal suo essere nel tempo. Ma questo non vale per l'uomo singolo, bensì per l'uomo come specie, là dove ci deve essere un garante del comune vincolo allo Höchstes Gut. Esso è infatti Endzweck e riferimento per tutti gli uomini, ma alla sua atemporalità e stabilità corrisponde la contingenza dei singoli. $\grave{E}$ qui che

\footnotetext{
${ }^{7}$ Seguo qui la traduzione di V. Cicero, indicandone il numero di pagina dopo il riferimento all'edizione tedesca.
} 
lo schematismo dell'analogia assume il suo valore politico: i singoli possono guardare al modello comune, a sua volta dipendente dal Bene.

Con il simbolo di Cristo Kant non vuole rendere visibile, come schema della moralità, il Gesù di Nazareth storico, ma permettere di credere a ciò che simbolizza, al suo «miracolo morale» ${ }^{8}$.

Oggetto della fede beatificante [...] è piuttosto lo stesso modello originario [Urbild] che, insito nella nostra ragione, poniamo alla base dell'Uomo-Dio [...] Percio la fede beatificante coincide con il principio di una condotta di vita gradita a Dio.[R 174-176, 283]

$\grave{E}$ in esso che il Cristianesimo conserva, «oltre al grandissimo rispetto che ispira irresistibilmente per la santità delle sue leggi», anche quella amabilità [Liebenswürdigkei] della costituzione etica [sittlichen Verfassung] fondata nel Cristo (EAD A338). Egli stesso assume i caratteri di una internità all'uomo che pone in secondo piano la sua Persona, estroflettendo sulla storia l'amabilità della Sache selbst. Grazie a questo movimento la chiesa visibile si supera in quella invisibile, vero passaggio filosofico-politico della Religione, che critica aspramente la feticizzazione del culto, così come in precedenza la Schwärmerey 9 .

\section{Liebenswürdigkeit: persuasione morale Vs coazione legislativa della Chiesa}

Cristo rappresenta il "padre morale comune ma invisibile» (R 144-146, 245) come immagine di una Chiesa proiettata dentro l'uomo (R 174-5). Il bisogno empirico della rappresentazione e dei segni esterni (ad esempio la Scrittura, $\mathrm{R}$ 157-158, 261 e R 162-163, 26) non inficiano, una volta riconosciuti come semplici sostegni, la vitalità di quella «idea sublime di una comunità» che la chiesa, come chiesa invisibile, è chiamata ad inverare (R 140-142, 241).

Dal punto di vista pratico, questa idea ha la sua realtà completamente entro se stessa. La sua sede è infatti nella nostra ragione moralmente legislatrice. Noi dobbiamo conformarci [gemäß] ad essa, ed è perciò necessario che si dia la possibilità di farlo. [R 75-77, 161]

Nel senso della prima critica (A 100) l'applicazione di un'immagine al campo della storia e alla ricerca del Regno di Dio sulla terra (R B131), corrisponde alla richiesta di seguire il modello eterno di Cristo nel tempo, rimanda alla produzione di un ideale trascendentale (KRV A572, B600, n.).

Seguendo questo modello originario l'uomo coglie la coerenza di scopo ultimo e scopo finale, di uomo come perfezione della natura e realizzazione

\footnotetext{
${ }^{8}$ Dierksmeier 1998: 95. Id., 86-87. Così come nei confronti dell'intellezione dove serve «alla conoscenza intellettiva immediata [unmittelbare Verstandeserkenntniß]» anche in ambito pratico, quindi, il simbolo col tempo deve cadere». Vorlesungen über die Metaphysik.

${ }^{9}$ Cf. Moura 1998: 78 ss.
} 
della natura umana al di là della natura biologica, nel regno dei fini. Per realizzarsi come moralità l'uomo deve agire nel tempo come se la fine di tutte le cose potesse avvenire ora (EAD A 5 I 7 ).

Il superamento della minorità in cose di religione viene raggiunta dall'uomo in quanto essenza morale qui ed ora solo grazie ad una immaginazione temperata con la ragione. Illuminato è l'uomo come plesso di intelletto-ragione, quando è libero nella scelta del fine. In questo senso la proposta del simbolo cristiano non deve limitare l'amabilità del Cristianesimo (R 75-77).

Tale conformazione è a sua volta una sorta di rivelazione interiore ${ }^{10}$, che deve però paradossalmente venir costruita e coltivata fino a diventare intenzione buona. Kant è contrario ad un pensiero della catastrofe, ma non ad una Revolution nell'intenzione morale che produce un uomo nuovo, come attraverso «una specie di rinascita, come una nuova creazione» (R 53-55, 135). In questo movimento l'uomo nuovo e l'uomo vecchio si sovrappongono, come tempo lineare finito e tempo eterno infinito, in un punto.

Il male, pur radicale, non può essere comunque ammesso da Kant se non come assunzione, da parte dell'uomo, di una massima contraria alla legge morale, e del suo utilizzo come principio di determinazione dell'agire. Inerisce all'uomo un Hang (tendenza) che ha la sua causa originaria anteriormente alla vita $[R 44-46,123]$, ma non è concepibile, mentre la Anlage (disposizione) originaria dell'nomo - imputata a lui solo, e della cui corruzione è responsabile è diretta al Bene [R 46-47, 125]. Il luogo utopico della costruzione teologico-politica kantiana è quindi da individuare nel superamento della religione come istituzione, nell'imitazione del modello di Cristo come formazione di un'attitudine costante, un'intenzione. Dell'accezione negativa di utopico rimane certo il fatto che questa intenzione,

che rappresenta [vertritt] la totalità di questa serie infinita di avvicinamenti progressivi, supplisce soltanto l'imperfezione di non essere mai integralmente quello che ci si propone di diventare. [R 85-87, 173]

\section{Bibliografia}

\section{Fonti}

W. Benjamin ( 1974 -), Gesammelte Schriften. Frankfurt a. M., Suhrkamp.

I. Kant (1900 -), Akademieausgabe. Berlin und Leipzig.

I. Kant (2001), Die Religion innerbalb der Grenzen der bloßen Vernunft, trad. it. La religione entro i limiti della semplice ragione, a cura di $\mathrm{M}$. Roncoroni, trad. di V. Cicero. Milano, Bompiani.

Platone (1907), Platonis Opera, ed. Ioannes Burnet. Oxford. 220 .

${ }^{10}$ Vorlesungen über die philosophischen Religionslehre, Von der Offenbarung, ed. Pölitz 1817: 


\section{Bibliografia secondaria}

J. Barata-Moura (I998), O tratado teológico-politico de Kant, in M. J. Carmo Ferreira e L. Ribeiro dos Santos (ed.), Religião, história e razão da Aufklärung ao Romantismo. Lisboa 65-97.

J. Brachtendorf (2002), Kants Theodizee-Aufsatz - Die Bedingungen des Gelingens philosophischer Theodizee, in Kant-Studien 93, 57-84.

G. Cunico (1992), Da Lessing a Kant. La storia in prospettiva escatologica. Genova.

F. Desideri (1991), Quartetto per la fine del tempo. Una costellazione kantiana. Genova.

C. Dierksmeier (1998), Das Noumenon Religion. Eine Unersuchung zur Stellung der Religion im System der praktischen Philosophie Kants. Berlin.

F. Menegoni (1988), Finalità e destinazione morale nella Critica del Giudizio di Kant. Trento.

P. Natorp (1903), Platos Ideenlehre. Leipzig

G. Panno (2004), "Crasi di scopo ultimo e scopo finale nell'annuncio di Das Ende aller Dinge, Studi Kantiani 17, 47-64.

A. Philonenko (1986), La Théorie Kantienne de l'histoire. Paris.

L. Tundo (1998), Kant: Utopia e Senso della Storia. Bari. 


\title{
DESCOBRIR COM JOVENS: ESPAÇOS E PAISAGENS DO TRVCVLENTVS DE PLAUTO ${ }^{1}$
}

\author{
Adriano Milho Cordeiro \\ Universidade de Coimbra \\ Centro de Literatura Portuguesa da FLUC
}

\begin{abstract}
Modern Secondary Education only permits us to develop superficial approaches to texts, contexts and landscapes presented by Greek and Latin authors with youngsters. We would like to realise a project that might turn out to be a herculean task: to translate, stage, and perform Plauto's TRVCVLENTVS with teenagers. That is our goal: to discover with youngsters, scenarios and landscapes from Ancient times that are very often contemporary with youngsters.
\end{abstract}

Keywords: learning, pedagogics, Plauto, theatre, Truculentus.

Palavras-chave: ensino, pedagogia, Plauto, teatro, Truculentus.

«Aos homens todos é dado conhecerem-se a si mesmos

e saberem pensar»

Heraclito, séc. VI-V a.C. ${ }^{2}$

\section{Objectivos, condicionalismos, vivências da Escola (pós-moderna)}

Apesar dos amotinados tempos que os Ensinos Básico e Secundário vivem hoje, em Portugal, ainda nos sobra uma mão cheia de alento para trabalhar e encenar com discentes, particularmente do Secundário, peças de autores da Antiguidade Clássica.

Focalizando:o principalobjectivo do Projecto que ora apresentamosé encenar com discentes do Ensino Secundário o Truculentus de Plauto. Necessitamos de alunos com alguma maturidade psicológica e alguma experiência de palco. Como conseguir matéria humana para concretizar tal aç̧ão?! A sementeira fazse no 3. ${ }^{\circ}$ Ciclo do Ensino Básico, quer nas aulas da disciplina de Teatro, quer

\footnotetext{
${ }^{1}$ Parafraseando Augusto Cury dedico este singelos pensamentos a todos

«[...] aqueles que procuraram não ser vítimas do rolo compressor da história, que procuraram dar um sentido mais nobre à sua vida e investir em sabedoria na sinuosa, turbulenta e bela existência humana.»

Augusto Cury ( $\left.{ }^{5} 2007\right)$, O Mestre dos Mestres, São Paulo, p. 5.

${ }^{2}$ Tradução de M. H. da Rocha Pereira ( $\left.{ }^{9} 2005\right)$, Hélade - Antologia da Cultura Grega. Porto, Edições Asa, p. 155.
} 
no mais ou menos (in)formal Clube de Teatro. Segundo Bartolomeu Valente deve-se «reanimar, mobilizar, interessar, porventura entusiasmar a comunidade educativa, de tal modo que devenha matriz de cultura viva e revitalizante [...] no âmbito da literatura [...] ou no da descoberta ou invento científicotecnológico [...] ou no das disciplinas críticas e qualitativas [...] história e [...] e filosofia ${ }^{3} . »$ Procuramos desinfantilizar paulatinamente para uma vida outra $^{4}$, a partir da componente educativa, legalmente institucionalizada, adaptada a cada caso e circunstância sempre «em prol da festa da cultura-vida, do desvendamento pessoal e comunitário, dentro e fora dos muros escolares ${ }^{5}$.» Segundo Yves Bertrand \& Paul Valois:

«As orientaçôes da organização educativa dependem das orientaçôes definidas pelo campo paradigmático. Estas orientaçôes são, em seguida, traduzidas em normas e leis pelo campo politico que, desta forma, regula a organização educativa. [...] No entanto, a organização educativa poderá também propor novos paradigmas socioculturais que designamos por contraparadigmas, uma vez que se opõem e procuram substituir um paradigma dominante. $[\ldots]^{6}$,

Em Outubro de 2005, numa conferência por nós proferida em Braga no V Congresso da $\mathrm{APEC}^{7}$, afirmámos: «Nas últimas décadas, quer o ensino da Língua e da Literatura Portuguesa quer a leccionação das disciplinas de Latim e Grego têm vindo a ser preteridas em relação a áreas curriculares que deformam $\mathrm{e}$, [alegadamente e de forma genérica] em nada contribuem para inteirar os discentes dos Ensinos Básico e Secundário nos saberes das ciências sociais e humanas [...]. A Expressão Dramática e o Teatro como áreas alternativas e possíveis nos actuais currículos, permitem a docentes e alunos, rebuscar n' "As Máscaras das Memórias Presentes e Passadas", ensinamentos, matérias

${ }^{3}$ Cf. Bartolomeu Valente (1998), Por uma Escola-Projecto. Lisboa, Livros Horizonte, p. 23.

${ }^{4}$ Idem, ibidem, p. 71.

${ }^{5}$ Ibidem.

${ }^{6}$ Yves Bertrand \& Paul Valois (1994), Paradigmas Educacionais - Escola e Sociedades. Lisboa, Instituto Piaget, pp. 30-31. Na contra capa desta obra diz-se algo de muito significativo: «A educação está unida à sociedade por laços indissociáveis. Determinado por orientações de natureza social, o sistema educativo tende a reproduzir e promover, modelos caros ao sistema social que o informa. Tal não significa porém, que a sua função criadora ou regeneradora deva ser ignorada ou negligenciada. Para os autores desta obra é esse, aliás, o papel essencial da educação. Esta obra apresenta uma panorâmica das diferentes teorias da educação, contrapondo-as aos vários tipos de organização social. Tendo em conta a alteração das relações entre a escola e o tecido social. Yves Bertrand e Paul Valois propõem uma alternativa mais ecológica e espiritual que favoreça a criação de uma comunidade educativa assente na valorização e no respeito pelas diferenças e liberdades individuais».

${ }^{7}$ Adriano Milho Cordeiro (2006), «As Máscaras da Memória. "O Nome da Rosa” no Convento de Cristo em Tomar - o teatro como factor de revisitação e perenidade da antiguidade da antiguidade clássica» in A Antiguidade Clássica e nós: Herança e identidade cultural. Braga, Universidade do Minho, Centro de Estudos Humanísticos, 567-573. 
atitudes, reflexões e estímulos que os novos tempos pretendem trazer, sem que o tenham assente ${ }^{8} . »$

Numa entrevista à revista Visão ${ }^{9}$, o escritor, professor, ensaísta Miguel Real, pseudónimo de Luís Martins, especialista em Cultura e Estudos Portugueses, afirma que «há um apagamento total da espiritualidade que Portugal desenvolveu em oito séculos. [...] A escola fomenta uma competição técnica feroz, promove o individualismo e renega o ensino dos valores da partilha, da honra, da lealdade, da motivação para as artes e a cultura. Hoje, nenhum aluno estuda para se motivar, estuda para médias e metas. A escola está totalmente submetida ao mercado. Já não interessa formar cidadãos humanistas, responsáveis e intervenientes. $\mathrm{O}$ fim das pessoas é o dinheiro, sempre. Portugal cheira alarvemente a dinheiro. [...] - [Esperava-se mais dos intelectuais:] - [...] Eduardo Lourenço falou dos perigos de estarmos a criar uma "Disneylândia cultural", ou seja, a reduzir a cultura portuguesa e europeia ao formato Hollywood. Hoje, é impossível estudar Grego no liceu. E é dificílimo estudar Latim. Pergunta-se: para que é que isso serve? Pois, mas as coisas que ficam na História são as que nos parecem inúteis no tempo em que foram feitas. O Camões recebeu uma tença anual de 15 mil réis para publicar Os Lusíadas. A viúva do João de Barros, que era feitor da Casa da India, recebeu 150 mil. Quem se lembra da viúva?»

O que pretendemos é muito simples. Já há muito que fizemos o diagnóstico à situação angustiante e sem sentido que se vive em Portugal, acerca de década e meia ou mais, pelo menos: «A missão da Escola democrática não pode estar arreigada às pressões conjunturais e tecnocraticamente eficazes em termos de destruição educativa ${ }^{10}$. Já em 1979 o filósofo francês Jean-François Lyotard

${ }^{8}$ No artigo, «Ainda a proposta de revisão curricular do ensino secundário e os novos programas de Latim e Grego» Boletim de Estudos Clássicos, 2002, 37, 165-169, escrito nos idos de 2002, indignados com o decorrer dos acontecimentos e com os perversos sinais dos tempos, nos dávamos conta da situação iníqua, descabida e altamente lesiva para os interesses educacionais em Portugal, nomeadamente no que diz respeito ao quase desaparecimento do ensino da Literatura Portuguesa, do Latim e do Grego. A reparação legislativa de Julho de 2007 (oficializada depois de uma grande parte das matrículas para o ano lectivo de 2007/2008, terem já sido efectuadas, em virtude de estarmos, então, quase nos finais de Julho; e acrescente-se que o mesmo DecretoLei introduziu mudanças de monta nos cursos e horários dos alunos) não desagrava o erro, pois, estas disciplinas continuam ostracizadas pelo poder instituído. A criação do Curso CientíficoHumanístico de Línguas e Humanidades resultante da junção do agrupamento G5 - Curso Ciências Sociais e Humanas e do agrupamento G7 - Curso Línguas e Literaturas, contemplando a oferta de disciplinas da componente de formação específica dos dois cursos é uma operação de mera cosmética. Cf. Decreto-Lei n. ${ }^{\circ} 272 / 2007$, publicado no Diário da República, 1. ${ }^{\text {a Série, }}$ n. 143 , de 26 de Julho, que altera as matrizes dos currículos dos cursos científico-humanísticos do Ensino Secundário.

${ }^{9}$ Cf. Visão, n.o 784, 13 de Março de 2008, pp. 54-58.

${ }^{10}$ José Augusto Cardoso Bernardes (2005), A Literatura no Ensino Secundário - Outros Caminhos. Porto, Areal Editores, pp. 47-48. Na nossa opinião, o conhecimento não pode ser reduzido apenas ao tão badalado "saber-fazer", sabendo quem está no terreno que os alunos terminam o $12 .^{\circ}$ ano a "saber-fazer" muito pouco, ou quase nada, ou como diz sabiamente o nosso povo: com uma mão cheia de nada e outra de coisa nenhuma. É nosso dever avisar que 
alertava para a desumanizada sociedade em que vivemos, a caminho do inumano, a deslegitimação das metanarrativas através de jogos de linguagem subtis $^{11}$, apoiados numa nova retórica, onde só o que é performativo ${ }^{12}$, é válido e passível de ser ensinável nas Escolas ${ }^{13}$. «A transmissão de saberes já não surge destinada a formar uma élite capaz de guiar a nação na sua emancipação, antes fornece ao sistema os jogadores capazes de assegurar convenientemente o seu papel nos lugares pragmáticos de que as instituições necessitam ${ }^{14}$.» «Os jogos de linguagem serão então jogos de informação completa no momento considerado ${ }^{15}$.»

Padecemos hoje de sisudas complicações ao nível da nossa identidade dilacerada por penetrantes metamorfoses pós-moderna ${ }^{16}$. Não desejamos de forma alguma como João Lobo Antunes afirmou recentemente, despejar sobre os alunos «o mais corrosivo dos ácidos - o do aborrecimento ${ }^{17}$.» As tarefas são

são muito poucos, apesar de hercúleos esforços, os alunos que terminam o $12 .^{\circ}$ ano. Será que as tão propaladas Novas Oportunidades, tão sublinhadas e propagandeadas, sobretudo de há três anos para cá, elevaram o nível de literacia do povo português?! Escusamo-nos neste momento e dada à natureza deste artigo de tecer quaisquer comentários em relação ao forjado e aparente sucesso apresentado e sufragado pelos dados estatísticos relativos ao Ensino Básico e Secundário em Portugal. A propósito será que a aplicação e ensino da tão propagada TLEBS (Terminologia Linguística para os Ensinos Básico e Secundário) trará algo de positivo para o ensino do Português?! Inequivocamente trará isso sim, é mais insucesso. Cf. http://www.ipetitions.com/ petition/contratlebs/

${ }^{11}$ A propósito da expressão e conceito - jogos de linguagem - veja-se Ludwig Wittgenstein (1989), Fichas (Zettel). Lisboa, Edições 70, p. 32.

${ }^{12}$ Performativo no texto acima escrito apresenta um sentido relacionado com lucro monetário ou com tudo o que o possa fazer acontecer. Ainda que retoricamente disfarcem os seus "jogos", os trilhos actuais ligados ao poder, ao mercado e ao Ensino transmitem-nos uma ideia bem clara e eticamente dissimulada: só o que é vendável tem sucesso e deve ser promovido no Ensino!... O resto deve ser relegado para segundo plano.

${ }^{13}$ Cf. Jean-François Lyotard ( $\left.{ }^{3} 2003\right)$, A condição Pós-moderma. Lisboa, trad. José Navarro, revista e apresentada por José Bragança de Miranda, Gradiva, pp. 12 e ss.

${ }^{14}$ Idem, ibidem, p. 99.

${ }^{15}$ Idem, pp. 132-133.

16 Segundo http://pt.wikipedia.org/wiki/Jean-Fran\%C3\%A7ois_Lyotard, «Jean-François Lyotard (Versalhes, 10 de agosto de 1924 - Paris, 21 de abril de 1998) foi um filósofo francês, foi um dos mais importantes pensadores na discussão sobre a pós-modernidade. Autor dos livros A Fenomenologia, A Condição Pós-Moderna e O Inumano. No seu livro A Condição Pós-Moderna (1979), utiliza o conceito de "jogos de linguagem", originalmente desenvolvido por Ludwig Wittgenstein, e refere-se a uma agonística entre esses jogos - característica da experiência da pós-modernidade, assim como a fragmentação e multiplicação de centros e a complexidade das relações sociais dos sujeitos. O título deste que é seu trabalho mais citado e conhecido, era originalmente $\mathrm{O}$ pós-moderno, tendo sido modificado para $A$ Condição Pós-Moderna para expressar uma condição de vivência. O Pós-Moderno seria “o estado da cultura, depois de transformações súbitas nas regras dos jogos da ciência, da literatura e das artes, a partir do século XIX. [...] Simplificando ao máximo, 'pós-moderno’ é a incredulidade em relação às metanarrativas.” Segundo Lyotard, "não podemos mais recorrer à grande narrativa - não podemos nos apoiar na dialética do espírito nem mesmo na emancipação da humanidade para validar o discurso científico pósmoderno".»

${ }^{17}$ Cf. Visão, n. ${ }^{\text {786, }} 27$ de Março de 2008, pp. 106-110. 
tormentosas, porém mescladas com afeição, prazer, dedicação hão-de produzir alguns bons frutos com o tempo, cidadãos conscientes, plenos na sua livre modulação do imaginário prontos para viver em alteridade com posturas, valores e práticas em harmónica relatividade com todas as épocas e situações. Também a missão da Universidade tem sido questionada ${ }^{18}$. A reinvenção é também uma das características da pós-modernidade ${ }^{19}$ ou da hipermordenidade ${ }^{20}$. Como afirmava Lyotard o realismo em que mergulhámos,

"seja lá o que for" é o do dinheiro: faltando critérios estéticos, continua a ser possivel e útil medir o valor das obras em função do lucro que se pode obter com elas. Este realismo acomodase a todas as tendências, como o capital a todas as "necessidades", desde que as tendências e as necessidades tenham poder de compra. [...] A pesquisa artística ou literária está duplamente ameaçada: pela "politica cultural" uma vez, e pelo mercado da arte e do livro outra [... $]^{21}$."

A formação para os valores continua hoje, na Escola, a ter uma pertinência indispensável e a apresentar-se como um elemento determinante da cultura geral da nossa época e porque inerente ao Homem, de todas as épocas. O

${ }^{18}$ Cite-se, e apenas como exemplo bibliográfico, sobre a sobrevivência e o papel das Universidades as seguintes obras: Jacques Derrida (2003), A Universidade sem Condição. Coimbra, Angelus Novus Editora; José Ortega y Gasset (2003), Missão da Universidade e outros textos. Coimbra, Angelus Novus Editora; Bill Readings (2003), A Universidade em Ruinas. Coimbra, Angelus Novus Editora.

19 Segundo http://pt.wikipedia.org/wiki/P\%C3\%B3s-moderno, «Pós-modernidade é a condição sócio-cultural e estética do capitalismo contemporâneo, também denominado pósindustrial ou financeiro. $\mathrm{O}$ uso do termo se tornou corrente, embora haja controvérsias quanto ao seu significado e pertinência. Tais controvérsias possivelmente resultam da dificuldade de se examinarem processos em curso com suficiente distanciamento e, principalmente, de se perceber com clareza os limites ou os sinais de ruptura nesses processos. Segundo um dos pioneiros no emprego do termo, o francês François Lyotard, a "condição pós-moderna" caracteriza-se pelo fim das metanarrativas. Os grandes esquemas explicativos teriam caído em descrédito e não haveria mais "garantias", posto que mesmo a "ciência" já não poderia ser considerada como a fonte da verdade. [...] O filósofo francês Gilles Lipovetsky prefere o termo "hipermodernidade", por considerar não ter havido de fato uma ruptura com os tempos modernos - como o prefixo "pós" dá a entender. Segundo Lipovetsky, os tempos atuais são "modernos", com uma exarcebação de certas características das sociedades modernas, tais como o individualismo, o consumismo, a ética hedonista, a fragmentação do tempo e do espaço. Já o filósofo alemão Jürgen Habermas relaciona o conceito de Pós-Modernidade a tendências políticas e culturais neoconservadoras, determinadas a combater os ideais iluministas.»

${ }^{20}$ Veja-se ainda sobre este assunto: http://pt.wikipedia.org/wiki/Hipermodernidade «Hipermodernidade é o termo criado pelo filósofo francês Gilles Lipovetsky para delimitar o momento actual da sociedade humana. O termo "hiper" é utilizado em referência a uma exacerbação dos valores criados na Modernidade, atualmente elevados de forma exponencial. A Hipermodernidade é caracterizada por uma cultura do excesso, do sempre mais. Todas as coisas se tornam intensas e urgentes. [...] O termo Hipermodernidade como idéia de exacerbação da Modernidade surgiu em meados da década de 70 e ganhou destaque em 2004 graças ao estudo de autores franceses e ao livro "Os tempos hipermodernos" do próprio Lipovetsky.»

${ }^{21}$ Cf. Jean-François Lyotard ( $\left.{ }^{2} 1993\right)$, O Pós-moderno Explicado às Crianças. Lisboa, trad. Tereza Coelho, Publicações Dom Quixote, pp. 19-20. 
objectivo principal é propiciar aos jovens o acesso a paradigmas culturais, cívicos e ético-morais que lhes sustentem: 1) as posturas para consigo mesmos, 2) os usos e os procedimentos para com os outros e 3) as atitudes ante a natureza e o cosmos ${ }^{22}$.

Se as Ciências Humanas conseguirão sobreviver na Universidade, ou no Ensino Secundário, disso não temos dúvidas. Por outro lado, a descentralização que preferimos apelidar antes de fragmentação pósmoderna ${ }^{23}$ exige quer por parte das Escolas a nível local, quer por parte de poderosos movimentos e facções autárquicas, programas culturais com alguma clarividência. Como já acima referimos, não é por acaso que o Cine-Teatro Virgínia e indirectamente a Câmara Municipal de Torres Novas possam vir a apoiar um projecto como é o nosso, o de pôr em cena o Truculentus de Plauto ${ }^{24}$. Temos então boas oportunidades para combater o neo-historismo também apelidado de não-historicismo, pois o estilo e as matérias do Truculentus de Plauto são inconfundíveis, porque são de todos os tempos, são o âmago da essência humana ${ }^{25}$. A entropia que se apregoa na

${ }^{22}$ Carlos Assunção \& José Esteves Rei (1999), Educar para os Valores. Lisboa, Ministério da Educação, Departamento do Ensino Secundário, p. 9.

23 Cf. Segundo o sítio http://pt.shvoong.com/social-sciences/1649447condi\%C3\%A7\%C3\%A3o-p\%C3\%B3s-moderna/ a pós-modernidade pode caracterizar-se da seguinte forma: «Não mais importa que se utilize o saber na construção de teorias especulativas sobre a condição da humanidade, sobre a finalidade da filosofia, ou sobre questões abstractas, que não tratem directamente de produção de técnica e produtos. Neste momento o saber adquire função estritamente técnica. A formulação de teorias sobre produtividade e tecnologias é o único saber importante, e este extracto já está determinado no início da década de setenta. Já se pode observar a queda das perspectivas de teorias sobre a humanidade como um todo, de unificação desta, ou mesmo da famigerada liberdade mundial, do projecto iluminista. Não há mais espaço para a especulação metafísica e, assim, não há mais que se discutir sobre a liberdade da humanidade. Muito menos, agora, ela pode ser vista como um todo; é o que se chama de fragmentação. [...] Lyotard, em sua crítica à pós-modernidade, está envolvido em todas estas questões, mas enfoca a questão do saber. Como a alienação da crítica ao consumo, vinculado o consumidor à ideologia deste consumo, está o ser pensante e com ele o pensamento. A ideologia da tecnologia, caracterizada por formas de aperfeiçoamento eterno e constante, dão a impressão ao homem de que o saber técnico é a realização da humanidade. Seja nos lares comuns, frente à televisão, o computador, mas principalmente nos âmbitos universitários o saber se instala como fonte de produção de tecnologia. Esta tecnologia tem a função de atender a demanda de produtos, máquinas e armas a serem produzidas. Ele chama isto de deslegitimação. O saber das instituições está vinculado a uma nova forma de saber: o optimizatório.»

${ }^{24}$ Áté porque o próprio eclectismo actual, sobre o qual Jean-François Lyotard reflectiu e ainda o facto de na condição pós moderna não haver previsão de todo, mas de fragmentações grupais, preocupadas com a sua segurança, faz com que nós e as facções onde nos integramos preocupemos e reajamos de forma enérgica. Bem observadas as modas, na pós-modernidade os artistas até têm maiores oportunidades para comunicar. Pouco nos importa que a quantidade incalculável de tendências e linguagens tornem impossível a unicidade formal. E depois há sempre grupos que fartos do mesmo em toda a parte, de similaridades estéticas e da premente homogeneização das relações de produção e dos hábitos de consumo exijam produtos culturais diferentes.»

${ }^{25}$ Diz-nos George Steiner (2007), A Ideia de Europa, Lisboa, Gradiva, pp. 35-36, relativamente à longa caminhada da história europeia afirma o seguinte: «[...] Um europeu culto é 
Pós-Modernidade diz respeito ao fim da interdição, à aceitação de todo e qualquer produto, pois, toda produção é considerada mercadoria que há-de ser regulada pelo mercado. Porém, já Gil Vicente no caso português observava no Auto da Feira que tudo era comerciável. Também João de Barros na sua Ropicapnefma ou Mercadoria Espiritual (1532) aborda o assunto, embora de uma outra forma.

Yves Bertrand \& Paul Valois dizem-nos que

\begin{abstract}
«A organização educativa que opta por uma aç̧ão crítica encontra-se à margem da cultura dominante. Além disso, um dominio total de um paradimgma sociocultural é absolutamente inconcebivel. Há sempre um contraparadigma. Gersick (1991) afirma que a história das organizaçôes mostra que a mudança revolucionária não pode ser contrariada constantemente e que, mais cedo ou mais tarde, sucederá a um período de estabilidade. [...] Ferguson (1987) lembranos que as modificações radicais, que se anunciam, residem, na sua opinião, numa concertação, ou seja, numa "conspiração" de pessoas que propõem novas opçôes educativas e societais ${ }^{26}$."
\end{abstract}

\title{
2. Pôr em cena, na Escola, O Truculentus de Plauto: à partida uma opção com sucesso
}

Confrontados com espaços e paisagens de outras eras, confrontados com um argumento tão actual, os nossos discentes até se mostram interessados em fazer algo.

«Uma cortesã finória, Fronésio, explora sem qualquer pudor, por todos os meios, os seus três amantes (um ateniense, Diniarco, o camponês Estrábax, e um soldado babilónio, Estrastófanes.

apanhado na teia de um in memoriam simultaneamente luminoso e sufocante. É precisamente esta teia que a América do Norte repudia. A sua ideologia tem sido a do nascer do Sol e da futuridade. Ao declarar que "História é palavreado inútil", Henry Ford forneceu a senha de acesso à amnésia criativa, a um poder de esquecimento que subjaz a demanda pragmática da utopia. O mais elegante dos novos edifícios possui um factor de obsolescência de uns quarenta anos. A guerra do Vietname lançou uma sombra quase digna do velho mundo, o onze de Setembro provocou um estremecimento, um memento mori na psique americana. Mas estes motivos excepcionais e quase certamente transitórios. As recordações mais fortes na sensibilidade e idioma americanos são as da promessa, daquele contrato com horizontes vastos que fez do movimento em direç̧ão ao Oeste, e, rapidamente, da viagem planetária, um novo Éden. Daí o crescente mal-estar sentido em relação ao mero pensamento de transformar em memorial a destruição (terá vida breve) do World Trade Center. Entretanto, um mausoléu deliberadamente brutal e, em minha opinião despropositado, sepultará um espaço central de Berlim. Quão mais verdadeiros ao manifesto de Jesus: «deixai os mortos enterrar os seus mortos», são os homens e as mulheres do Novo Mundo! O peso ambíguo do tempo verbal pretérito na ideia e substância da Europa deriva de uma dualidade primordial - que constitui o meu quarto axioma: a herança dupla de Atenas e Jerusalém. Esta relação, simultaneamente conflituosa e sincrética, ocopou o debate teológico, filosófico e político dese os Doutores da Igreja a Leon Chestov, de Pascal a Leo Strauss. O topos é Agora tão rico e premente como sempre. Ser europeu é tentar negociar, moralmente, intelectualmente e existencialmente, os ideias, afirmações, praxis rivais da cidade de Sócrates e da cidade de Isaías. [...].

${ }^{26}$ Yves Bertrand \& Paul Valois (1994), Paradigmas Educacionais - Escola e Sociedades. Lisboa, Instituto Piaget, pp. 32-33. 
Estrábax tinha um escravo, Truculento, verdadeiramente fiel ao seu nome (que exprime rudeza, mau carácter), que costuma travar memoráveis discussöes com Astáfio, a escrava de Fronésio, em nada indigna da sua patroa. Para continuar a merecer a atenção do soldado, Fronésio forja um engano e convence a sua vítima de ter uma criança dele. Por fim, o engano vem a ser descoberto, e um dos outros dois jovens, Diniarco, acaba por casar com a verdadeira mãe da criança, uma mulher de condição livre que ele mesmo tinha seduzido ${ }^{27}$.»

Censurou-se muitas vezes ao Truculento a sua imoralidade; não sem razão. É certo que Fronésio é a mais libertina e a mais cúpida das cortesãs de Plauto; o seu cinismo só é ultrapassado pelo de Diniarco. Há poucos exemplos de um amante a quem a paixão tenha também pervertido completamente. Todos os actos sexuais que pede a Fronésio, ele realiza-os alegremente ultrapassando todas as suas exigências. Cegueira do amor, admitamos; mas como desculpar então a sua conduta perante a filha de Cálicles, esta violação, este abandono? Sem dúvida ele "dará reparação" pelo casamento, mas sem renunciar a Fronésio, da qual continuará a ser, depois como antes, o amante, o conselheiro, o servidor e o cúmplice. Solteiro, ele é digno de dó; casado, ele tornar-se-á odioso. Alguma indulgência que se possa ter pelas estroinices dos jovens, tem-se dificuldade em tolerar Diniarco e sente-se na leitura da peça uma impressão de mal-estar, mesmo de repugnância. É preciso acreditar que o público romano não era tão difícil e depois Diniarco era apenas um grego. Seria necessário formalizar-se com os costumes e o carácter dum Graeculus esuriens ${ }^{28}$ ?»

Algumas boas sementes andam por aí, germinando por vezes, em obscuros solos, esfumando universos oníricos que devem ser bem consubstanciados pelos educadores. Uma seara maior falta advir. $\mathrm{Na}$ verdade, o quê e como intervir junto dos jovens requer criatividade, imaginação e logicamente um mínimo de conhecimento das circunstâncias e conjunturas em que as experiências em mente podem resultar. Por muito entusiastas e empenhados que sejamos, nem sempre se consegue com facilidade - e refira-se estamos a ter em linha de conta todas as partes envolvidas - informações bastantes, constatação de competências e sensibilidades apuradas para pôr em cena com jovens hodiernos e, nossos discípulos, uma peça como o Truculentus de Plauto.

Conseguir alunos para pequenas representações não é difícil. Porém, pensar em encenar pela primeira vez em Língua Portuguesa, ao que julgamos, o Brutamontes do Sarsinate não é tarefa dócil. Para que tudo se torne viável tem de existir primeiro todo um trabalho de tradução e perscrutação sobre a peça e

${ }^{27}$ M. Citroni et al. (2006), Literatura de Roma Antiga. Lisboa, Fundação Calouste Gulbenkian, p. 110 .

${ }^{28}$ Cf. Plaute, Comédies (1961), Texte établi et traduit par Alfred Ernout, Tomo VII, 2 ème éd. rev. et corr. Paris, Les Belles Lettres, pp. 92-95. 
ao mesmo tempo ensaiar experiências teatrais com os alunos. Ainda assim, esta é labuta exclusivamente do docente.

Infelizmente, a temática da peça plautina em causa, é duma actualidade lancinante e atroz. Talvez seja esse o motivo condutor que entusiasma os nossos aprendizes de sonhos, pois que os mesmos, ou similares assuntos desenvolvidos no Truculentus são hoje triviais, aos ouvidos ou à vista dos homens e das sociedades, todavia, conteúdo importante nos diversos meios de comunicação social.

Em educação nada ocorre por obra de magia e as maturações brotam de duráveis paciências e laboriosas indagações. $\mathrm{O}$ Teatro pode ser para os jovens de hoje o que foram as parábolas para os cristãos - sementes para germinar e frutificar. Não há dúvida de que vivemos num mundo tecnicizante que tende reduzir tudo a números. Por vezes e, como tão bem opina Bartolomeu Valente:
"[...] o problema é, pois, como reanimar, mobilizar, interessar, porventura entusiasmar a comunidade educativa, de tal modo que devenha matriz de cultura de cultura viva e revitalizante, ressuscitando o pulsar das criações presentes como dos tempos idos, em lugar de recoveira tanto dos sentidos de antanho como dos actuais, no âmbito da literatura (não há poema, conto nem romance que aguente o agredir das análises, obrigatoriedadades e avaliaçôes legais dos alunos) ou no da descoberta ou invento científico-tecnológico (mesmo os laboratórios, oficinas e trabalhos de campo se tornam entediantes no contexto impositivo e pré-programado actual) ou no das disciplinas críticas e qualitativas (a história e afins [...] a filosofia [...]”

Por termos vivido experiências anteriores algo semelhantes, ainda que de menor projecção lançamo-nos agora na tentativa de pôr em cena uma obra. Podemos contar à partida e para já com dois apoios institucionais importantes: a Escola Secundária de Maria Lamas, o Teatro Virgínia de Torres Novas e vários Professores do Instituto de Estudos Clássicos da Faculdade de Letras da Universidade de Coimbra. Sei que os discentes têm disponibilidade interior para prosseguir com a hercúlea tarefa. O problema maior prende-se com o tempo disponível por parte dos discentes. Ajustar um ou dois tempos por semana que permitam que a encenação possa ser vivida por todos e ao mesmo tempo é tarefa árdua e quase impossível ${ }^{29}$.

$\mathrm{O}$ professor deve de preparar os alunos para que estes tenham aproveitamento na Área Projecto no final do $12 .^{\circ}$ ano, pois tal como noutras disciplinas, também a Área Projecto tem diferentes níveis e patamares de desenvolvimento. «Concluem o nível secundário de educação os alunos que obtenham aprovação em todas as disciplinas e áreas não disciplinares do plano de estudos de respectivo curso.» (Art. ${ }^{\circ} 14 .^{\circ}$ do Decreto-Lei n. ${ }^{\circ} 74 / 2004^{30}$.)

${ }^{29}$ Estamos a optar muitas das vezes por encenações parciais, pois os condicionalismos são muitos e prendem-se sobretudo com a forma como o curriculum escolar é plasmado em termos de horário.

${ }^{30}$ Cf. Manuela Matos Monteiro (2007), Área de Projecto. Porto, Porto Editora, p. 13 
$\mathrm{Na}$ verdade o Homem deve revelar-se ao longo da vida como «um animal com memória e projecto ${ }^{31}$.»

«É preciso adaptar de acordo com as características de cada aluno, de acordo com as suas necessidades. É premente que exista flexibilidade para cada escola poder dar aos seus alunos os ensinamentos que os motivem, que lhes proporcionem sucesso, que desenvolvam as suas capacidades e enriqueçam os seus conhecimentos. Tudo isto é possível se alterarmos as nossas estratégias e se repensarmos a forma de avaliar ${ }^{32}$.»

O teatro pode ter domínio terapêutico, pois permite aos adolescentes libertarem-se da sua pessoalidade e viver o gosto de uma existência nova não podendo ser considerado como um luxo ${ }^{33}$. O teatro é a mais completa e acabada maneira de educar e deleitar sintetizando um conjunto muito importante de actividades culturais, recreativas e artísticas ${ }^{34}$.

Opina e muito bem Glória Bastos que «[...] é através das personagens que o leitor contacta não só com as peripécias da fábula, como referimos, mas ainda com diversas concepções da realidade, consoante o ponto de vista expresso. A função de tais relatos é assim também interpretativa, pois não se trata de um narrador omnisciente que perspective a narrativa de uma forma globalizante, mas de diferentes personagens com leituras diversas do mundo ${ }^{35}$.»

Parafraseando Tito Agra Amorim: «É óbvio também que muita da informação que adquirem os nossos jovens de hoje é bebida fora da escola. Bom ou mau? Para mim apenas motivo para reflexão, e alimento para dar consistência às actividades que me têm permitido uma maior aproximação com os jovens e a partilha de uma praxis que valoriza as componentes humanas e vivenciais e que permite solidificar relações, fazer nascer curiosidades e viver mais intensamente um tempo de incertezas, de encontros e de desencontros ${ }^{36}$."

Reconstruamos assim uma paideia nova assente na motivação de reler os clássicos e descobrir neles coisas novas neste inimaginável mundo novo, rodeados de tecnologias e todavia ao mesmo tempo de saberes antigos que

${ }^{31}$ Cf. André Lichnerowicz citado por Diana Felizardo (2004), op. cit., p. 7.

${ }^{32}$ Diana Felizardo (2004), op. cit. p. 5.

${ }^{33}$ A este respeito afirma Louis Porcher (1982), Educação Artística - Luxo ou Necessidade. São Paulo, Editora Afiliada, p. 9: «Aqueles que identificam a Educação Artística como luxo não declararam apenas uma compreensão inadequada das funções intrínsecas de tal prática, mas revelam um compromisso com postulados educacionais onde o aluno é objecto ou unicamente o significante. Não reconhecem a escola como local onde o sujeito deve se significar e tornar-se senhor do seu próprio destino. Não procede identificar como luxo o acto de reconhecimento de uma necessidade original do sujeito: a de participar das manifestações estéticas existentes no mundo e capacidade de estender sua intuição poética, no fazer.»

${ }^{34}$ Cf. Bárbara Vasconcelos de Carvalho (1989), A literatura Infantil. São Paulo, Global Editora, p. 267.

${ }_{35}$ Veja-se Glória Bastos (1999), Literatura Infantil e Juvenil. Lisboa, Universidade Aberta, pp. 207-208.

${ }^{36}$ Cf. Tito Agra Amorim (1995), Encontros de Teatro na Escola - História de um Movimento. Porto, Porto Editora, p. 26. 
remontam aos primórdios da Humanidade! Cidadãos conscientes, revisitemolos pois e, logremos!

$\mathrm{Na}$ opinião de George Steiner ${ }^{37}$,

«[...] Se os jovens ingleses escolhem classificar David Beckham acima de Shakespeare e Darwin na lista de tesouros nacionais, se as instituições culturais, as livrarias e as salas de concertos e teatro lutam pela sobrevivência numa Europa que é fundamentalmente próspera e onde a riqueza nunca falou tão alto, a culpa é muito simplesmente nossa. Assim como o poderia ser a reorientação do ensino secundário e dos meios de comunicação social, por forma a corrigir esse erro. [...] É porventura apenas na Europa que as fundaçôes necessárias de literacia e o sentido da vulnerabilidade trágica da condition humaine poderiam constituir-se como base.

É entre os filhos frequentemente cansados, divididos e confundidos de Atenas e de Jerusalém que poderíamos regressar à conviç̧ão de que "a vida não reflectida" não é efectivamente digna de ser vivida.»

É vital que como europeus reafirmemos certas convicções e arrojos de alma que a americanização do planeta anuviou ${ }^{38}$. A nossa herança é demasiado importante para que a percamos, jovens e seniores.

Caro e admirável Plauto: não morreste, a comédia não chora, o palco jamais será abandonado, e, por conseguinte, o riso, o jogo, a troça, e os ritmos inumeráveis, todos eles gracejam! Espaços e Paisagens de e para SEMPRE!

${ }^{37}$ George Steiner, op. cit., p. 55.

${ }^{38}$ George Steiner, op. cit., p. 53. 
(Página deixada propositadamente em branco) 


\title{
REFLEXOS DO ESPAÇO DE EXÍLIO OVIDIANO \\ NO LIVRO DO DESASSOSSEGO
}

\author{
Rodolfo Pais Nunes Lopes \\ Universidade de Coimbra \\ rodolfo.nunes.lopes@gmail.com
}

\begin{abstract}
It's not in the work of Ovid that one can see the first manifestations of the so called Literature of Exile, because the Odyssey, for instance, shows us some evidences, but it is surely this author who finally establishes it as literary code; and, in order to achieve that status, the spatial component assumes an extremely important role. This idea is very clear in Ovid's work, but it can also be found in several other authors, since ancient to modern times, that somehow wrote about exile, as for instance in Bernardo Soares' Book of Disquietment. Although situated in another kind of exile, Soares shares many topoi with Ovid, particularly in what concerns the space, with all the semantic implications that this word has.
\end{abstract}

Keywords: Bernardo Soares, Ovid, space of exile.

Palavras-chave: Bernardo Soares, espaço de exílio, Ovídio.

Antes de entrar propriamente no confronto dos dois autores em causa - Ovídio e Bernardo Soares -, convém clarificar quais serão as linhas metodológicas sob as quais se desenrolará este estudo. Todavia considerando Ovídio o ponto de partida e Soares o de chegada, a tarefa de estabelecer uma ligação entre os dois não assenta em identificar decalques directos dos versos daquele nas linhas deste nem muito menos em supor que a escrita do Livro do Desassossego implica a leitura dos textos ovidianos. Ela poderá ter acontecido, mas não é condição obrigatória. Mais do que de palavras ou de frases, a relação toma corpo através de ideias, tópicos e concepções.

Ovídio, ainda que não tenha sido pioneiro a cantar o exílio, foi sem dúvida pioneiro, no contexto do cânone ocidental, a construir aquilo a que podemos chamar uma poética do exílio. Ainda que não seja este o local para explorar todas as implicações de tal concepção, bem como tem sido um assunto bastante e bem estudado ${ }^{1}$, é por todos sabido que os topoi estabelecidos por este autor nos versos dos Tristia e das Epistolae Ex Ponto exerceram uma influência tal na Cultura Ocidental que podemos considerar estas obras uma autêntica gramática da literatura de exílio. Ora, parece também evidente que, tratandose de uma manifestação transversal, a poética ovidiana se foi instalando e

\footnotetext{
${ }^{1}$ Poderia citar uma infinidade de títulos, mas, pelo rigor e riqueza bibliográfica que apresenta, remeto para André 1992: 29-98.
} 
enraizando no lastro cultural, criando um substrato de tal forma profundo que não será de todo impossível encontrar alguns destes topoi em escritos de quem nunca tenha lido Ovídio.

Entre as várias componentes que a manifestação literária do exílio combina, o espaço assume um papel sem dúvida preponderante; aliás, a condição que configura o exilado depende da privação de um espaço e posterior ocupação de um outro. Além disso, do ponto de vista da criação poética, a categoria espacial, juntamente com a temporal, é fundamental no processo de exteriorização deste sentimento ${ }^{2}$. Neste caso particular, a atenção estará virada para o espaço ocupado pelo exilado, tendo em atenção os sentidos que esta palavra poderá ter para além de local físico e geograficamente identificável.

Ainda que os dois autores em causa manifestem duas vertentes diferentes de exílio, no que respeita ao espaço a única grande diferença tem que ver com a viagem. É que, enquanto Ovídio se viu privado da sua pátria a partir da qual viajou para um outro local, Soares vive, paradoxalmente, exilado na sua própria pátria ${ }^{3}$; ou seja, num caso há uma constante ansiedade de regresso a um lugar específico, enquanto que, no outro, o sentimento é de aspiração a uma fuga sem destino anunciado: Porém tu, vai em vez de mim; tu, a quem isso épermitido, contempla Roma, diz Ovídio ${ }^{4}$; Partir da Rua dos Douradores para o Impossivel... Erguer-me da carteira para o Ignoto..., diz Soares ${ }^{5}$. Mas visto que se trata de caracterizar o espaço, independentemente de qual seja o seu antípoda, esta questão é meramente acessória.

De um modo geral, a caracterização do espaço de exílio na sua vertente geográfica assenta sobretudo na identificação de certos traços que provocam no sujeito um sentimento de incómodo e desadequação. Este processo de construção disfórica vemo-lo consolidado nos versos de Ovídio, quando descreve a terra dos Getas como o lugar mais lúgubre do mundo: não pode haver nada mais triste em todo o orbe ${ }^{6}$; uma terra de ninguém abandonada ao desprezo, semelhante a um deserto totalmente estéril: para onde quer que olhes jazem campos carentes de trato / e vastas terras que ninguém reclama ${ }^{7}$; quanto ao clima, também ele é horrendo e insuportável: ainda antes de a primeira camada de neve se derreter, uma outra chega ${ }^{8}$. A imagem da neve eterna como elemento natural que impede qualquer relação que o sujeito possa estabelecer com o meio fecha assim a construção do locus horrendus, lugar onde não pode haver vida nem tranquilidade. E se o meio é hostil, o que dizer de quem o habita;

2 Apud André 1991: 83.

${ }^{3}$ Sublinha Solanes que o sentimento de exílio não pressupõe afastamento físico da pátria cf. Solanes 1948: 62.

${ }^{4} \operatorname{Tr}$. 1.1.57.

${ }^{5}$ Frg. 42. Todas as citações do Livro do Desassossego se referem à edição de Richard Zenith (B. Soares, Livro do Desassossego. Lisboa, Assírio \& Alvim, 2003).
${ }^{6}$ Tr. 5.7.44.
${ }^{7}$ Pont. 1.3.55-56.
8 Tr. 3.10.15. 
afirma Ovídio que com os autóctones, mais selvagens e ferozes do que os lobos ${ }^{9}$, não é possível comunicar: com a gente bravia nenbum contacto posso ter pela fala ${ }^{10}$. Portanto, além de lhe estar vedada qualquer relação com o meio natural, o poeta não consegue estabelecer uma ligação por mais ténue que seja com os outros indivíduos, visto que nem ele próprio conhece a língua deles, nem eles conhecem a sua. Quer isto dizer que o conjunto de todos estes elementos acaba por criar uma barreira inultrapassável para se integrar no local onde está exilado, provocando nele um irremediável sentimento de isolamento e desadequação.

Quanto ao Livro do Desassossego, nele podemos também encontrar alguns reflexos, mais ou menos evidentes, daqueles topoi usados por Ovídio na caracterização do espaço de exílio. Também Soares o concebe como um lugar inóspito, um pesadelo inestético, como um resultado nos sonhos de uma indigestão de espirito ${ }^{11}$, um meio que lhe causa um mal-estar que se chega a manifestar de forma somática como se dum pesadelo se tratasse. De igual modo, as pessoas que habitam este meio provocam-lhe como que um sentimento de repulsa e desprezo; numa das passagens, Soares vai descrevendo, como mero espectador, algumas cenas de convivência social e relatando algumas das conversas que vai ouvindo e, no fim da narrativa, resume o que vira, ouvira e sentira do seguinte modo: tudo isto me produz a impressão de um animal monstruoso e reles, feito no involuntário dos sonhos, das côdeas húmidas dos desejos, dos restos trincados das sensações ${ }^{12}$. Todos estes "quadros urbanos" que vai observando lhe fazem sentir uma repulsa como se estivesse na presença de uma quimera horrenda e temível; tudo o que vê são restos e detritos: côdeas húmidas - uma espécie de lixo reaproveitado. Por isso, sente uma terrível dificuldade de comunicar com aqueles que o rodeiam, muito embora o consiga fazer consigo mesmo: sou capaz, a sós comigo, de idear quantos ditos de espirito (...), mas tudo isso se me some se estou perante um outrem físico ${ }^{13}$. Mais do que não querer, Soares não consegue comunicar; o estranhamento que sente em relação ao outro é tal que a sua simples presença lhe bloqueia todas as capacidades de interacção pela palavra.

Também o topos do clima adverso encontra paralelo no Livro do Desassossego como contributo para a construção disfórica do espaço de exílio. Num fragmento de tom marcadamente pessimista, Soares diz que chove muito, mais, sempre mais... Há como que uma coisa que vai desabar no exterior negro ${ }^{14}$. Tal como a neve eterna de Ovídio, também a chuva de Soares cai ininterruptamente, impedindo qualquer tentativa de contacto com o meio exterior, este um negrume sobre o qual algo ameaça desabar. Em ambos os

\footnotetext{
$9 \operatorname{Tr}$. 5.7.46.

${ }^{10}$ Tr. 3.11.19.

${ }^{11}$ Frg. 35.

12 Frg. 62.

${ }^{13}$ Frg. 49.

14 Frg. 69.
} 
casos, é patente a ideia de que até a natureza é hostil no espaço de exílio; coligada com os outros factores, contribui para que o sujeito se isole cada vez mais, por não ter quaisquer hipóteses de integração nem com o meio nem com quem o habita.

Em ambos os casos, a conjugação de elementos prejudiciais ao sujeito poético acabam por conduzi-lo a uma condição de eterno estrangeiro ${ }^{15}$. Cada vez mais isolado, redefine as fronteiras do seu espaço psicológico, fechando-se dentro de si mesmo e evitando contactos com o exterior, situação que pouco a pouco vai transformando a sua vida numa dolorosa e vazia existência: Perdi tudo, somente me foi deixada a vida, / para me oferecer a consciência e a essência dos meus males ${ }^{16}$, diz Ovídio; não aspiro a nada. Dói-me a vida. Estou mal onde estou e já mal onde penso em poder estar ${ }^{17}$, diz Bernardo Soares. O tom de ambos é de profundo desespero, em virtude da tomada de consciência de não ser possível atingir a coisa perdida; no caso de Ovídio, podemos falar seguramente em saudade, no sentido mais lusitano da palavra, pois, além desta situação de angústia estar intimamente ligada à perda, depende também do meio e das circunstâncias em que o sujeito que dela sofre se encontra ${ }^{18}$; quanto a Soares, embora o sentimento seja semelhante, é bem mais adequado o termo germânico que mais ou menos lhe equivale: a Sehnsucht, tal como a define Carolina Michaëlis de Vasconcelos: "em regra, a Sebnsucht alemã tem um carácter metafórico. Aspira a estados e a regiões ideais, sobre-humanas: ao Além"19. Ainda que não seja lícito dizer que Soares pretenda atingir o Além, parece evidente que o espaço a que aspira será algures entre o metafórico e o sobre-humano; qualquer coisa como o nãolugar, a negação do meio que o envolve ${ }^{20}$.

Situados sensivelmente no mesmo plano psicológico, a ambos cabe uma definição de uma forma de angústia marcada pela consciência da sua perenidade e irreversibilidade: a melancolia. Em termos psicanalíticos, o estado melancólico implica um trauma resultante de uma falta precoce ou inesperada que, por sua vez, resulta num enfraquecimento progressivo e exponencial do si e, ao contrário do luto, não tem um carácter provisório ${ }^{21}$. De acordo com Ricardina Guerreiro, o melancólico é, de certa forma, um exilado: "culpado de saber que o caminho é de inalcance e inocente do exílio que alguém the outorgou, ele é, a um tempo, o expulso e o caído"22.

Para tentar escapar a este espaço psicológico delimitado pela condição de exilado, o sujeito tenta encontrar uma saída na criação poética. Ovídio diz muito

${ }^{15}$ Diz Kristeva que a condição do estrangeiro se resume a "n’appartenir à aucun lieu, aucun temps, aucun amour. Lorigine perdue, l'enracinement impossible, la mémoire plongeante, le présent en suspense" (Kristeva 1988: 18).

16 Pont. 4.16.49-50.

${ }^{17}$ Frg. 182.

18 apud Ferreira 1986: 338.

${ }^{19}$ Vasconcelos 1986: 147.

20 cf. Karatsón 1982: 144.

${ }^{21}$ apud Guerreiro 2004: 188.

22 ibidem. 
claramente: procuro na poesia o esquecimento das desgraças ${ }^{23}$. Quanto ao Livro do Desassossego, se o considerarmos uma obra literária e não um diário - opinião legitimada, por exemplo, por J. Gaspar Simõe ${ }^{24}-$, nele também encontramos semelhante concepção: se escrevo o que sinto é porque assim diminuo a febre de sentir $^{25}$. Considerada a criação poética como catarse, no seu sentido mais mais médico, escrever será então um acto de purgação, o que implica que o teor dos versos ou linhas seja conivente com o ambiente do espaço psicológico em que o sujeito se movimenta. Ovídio, outrora poeta do amor, canta agora no exílio os seus infortúnios e justifica essa mudança de orientação temática exactamente com a sua condição actual: se algum de vós se interroga porque são muitos /os males que eu canto, é porque muitos males sofri ${ }^{26}$. Semelhante ideia manifesta Soares que, ao falar sobre o conteúdo daquilo que escreve, diz que estas são as minhas Confissões, e, se nelas nada digo, é que nada tenho a dizer ${ }^{27}$.

Espartilhado no seu espaço psicológico, o sujeito tenta assim minimizar o estrangulamento através do canto. A criação deste mundo fingido, deste palco em que sobrevive mascarado, funciona como um mecanismo de suplementação; um lugar outro em que o $e u$ vazio se projecta sob o traje poético. A poesia como mentira, fingimento e máscara, conceitos que segundo Kierkegaard, Oscar Wilde, Yeats ou mesmo Pessoa, são indissociáveis do fenómeno artístico, assume, então, um papel de antídoto para a dura realidade. Todavia, esta estratégia, quer num caso, quer no outro, apenas proporciona ao sujeito como que um analgésico temporário, visto não ter o poder de preencher por completo o vazio em que ele se encontra. Ovídio, ao tomar consciência de que não consegue regressar a Roma, pede ao livro que escreveu que faça a viagem por ele: na tua insignificancia - nisso não te invejo - sem mim, ó livro, partirás para Roma: / ai de mim, já que a teu amo não épermitido acompanhar-te ${ }^{28}$. De igual modo, Soares, ao reler o que escrevera, apercebe-se da ineficácia da criação poética enquanto suplemento perfeito e confessa a dor que sente pelo desmembramento da ilusão que a si próprio criara: não é isto, porém, que sinto e que me dói no que fiz, nestes lentos momentos em que o releio. O que me dói é que não valeu a pena fazê-lo, e que o tempo que perdi no que fiz o não ganhei senão na ilusão, agora desfeita, de ter valido a pena fazê-lo' ${ }^{29}$.

A máscara é, portanto, uma espada de dois gumes. Se por um lado oferece ao sujeito melancólico uma possibilidade de construir um espaço alternativo onde possa refugiar-se, por outro, acaba por multiplicar a sua angústia, em virtude da sua ineficácia de substituir por completo a coisa perdida e desejada. Além disso, ao tornar-se num vício a que recorre para diminuir a sua febre

\footnotetext{
${ }^{23} \operatorname{Tr}$. 5.7.67.

${ }^{24}$ vide Simões 1985: 582.

${ }^{25}$ Frg. 12.

${ }^{26} \operatorname{Tr} .5 .1 .25-26$.

${ }^{27}$ Frg. 12.

${ }^{28} \operatorname{Tr} .1 .1 .1-2$.

${ }^{29}$ Frg. 169.
} 
de sentir, como diria Soares, a mesma máscara vai também contribuir para a corrosão do eu; o sujeito entra então num ciclo sucessivo e ininterrupto de engano/desengano, expectativa/frustração, qual Tântalo que, embora saiba à partida que não conseguirá alcançar a água nem os frutos, não deixa nunca de tentar. "A máscara está colada à cara e o traje colado ao corpo"30, como refere Marisa Pêgo a propósito de Bernardo Soares, mas a mesma ideia se aplicará com justiça a todos os melancólicos.

Dito isto, parece evidente que, na concepção poética do exílio, a um espaço geográfico está associado um psicológico e a este um outro de natureza poética. As circunstâncias que enquadram o primeiro determinam a configuração do segundo e, por sua vez, a criação do terceiro. Entre todas estas inter-relações espaciais encontra-se um sujeito dividido, indeciso e instável que ocupa assim uma área transversal que perpassa aquelas três vertentes. Torna-se numa criatura de fronteira que parece habitar o limiar entre o real e o fingido; indeciso sobre qual será o seu papel ou a sua condição, desconhece-se e estranha-se, reconfigurando para si uma entidade ontológica dispersa e movediça. Nas palavras do próprio Bernardo Soares, sou postiço. Acordei sempre contra seios outros, acalentado por desvio ${ }^{31}$.

\section{Bibliografia}

Carlos Ascenso André (1992), Mal de ausência : o canto do exílio na lírica do humanismo português. Coimbra, Minerva.

(1991): "Uma planura ressequida: Ovídio e a poética do exílio”, Biblos 66 77-101.

João Ferreira (1986), “A Saudade, nova dimensão psíquica do Homem” in A. Botelho, A. Teixeira (orgs.), Filosofia da Saudade. Lisboa, IN-CM, 334350.

Ricardina Guerreiro (2004), De Luto por Existir - a melancolia de Bernardo Soares à luz de Walter Benjamin. Lisboa, Assírio \& Alvim.

André Karatsón (1982), Déracinement et Littèrature.Lille, Presses del'Université de Lille III.

Julia Kristeva (1988), Étrangers à nous-mêmes. Paris, Gallimard.

Marisa I. Mateus Pêgo (2007), A unidade múltipla de Bernardo Soares. Coimbra, Centro de Literatura Portuguesa.

João Gaspar Simões (1985), "O Livro do Desassossego, um falso «diário íntimo»" in Actas do II Congresso Internacional de Estudos Pessoanos (Nashville). Porto, Centro de Estudos Pessoanos, 581-586.

Bernardo Soares (2003), Livro do Desassossego. Lisboa, Assírio \& Alvim, ed. Richard Zenith.

\footnotetext{
${ }^{30}$ Pêgo 2007: 133.

${ }^{31}$ Frg. 30.
} 
José Solanes (1948), "Exil et troubles du temps-vécu”, L'Hygiène Mentale 35.5 62-78.

Carolina Michaëlis de Vasconcelos (1986), "A Saudade Portuguesa” in A. Botelho, A. Teixeira (orgs.), Filosofia da Saudade. Lisboa, IN-CM, 145160. 
(Página deixada propositadamente em branco) 


\title{
AMBIÊNCIA CLÁSSICA EM INVECTIVAS ÀS DITADURAS MILITAR E SALAZARISTA
}

\author{
Carlos Morais \\ Universidade de Aveiro \\ Centro de Linguas e Culturas \\ cmorais@ua.pt
}

... através do artifício de uma antiga bistória, eis o debate que é de hoje, sobre temas sociais que são de hoje. A. SÉRGIO, Antigona, c. 1950, pp. 3-4.

\begin{abstract}
In António Sérgio's Antigones spaces and figures drawn from the classical world are allegorical and parodic figurations of spaces and figures from the second quarter of the Portuguese $20^{\text {th }}$ century.
\end{abstract}

Keywords Beotia, bucolism, military dictatorship, Orchomenos, Phocide, Portugal, Russia, salazarism, Scythia, Sérgio, Sophocles, Spain, Thebes, Theocritus.

Palavras-chave: Beócia, bucolismo, Cítia, ditadura militar, Espanha, Fócida, Orcoménia, Portugal, Rússia, salazarismo, Sérgio, Sófocles, Tebas, Teócrito.

Atravessado por uma longa ditadura de quase cinco décadas, o séc. XX português foi palco ideal para a evolução do mito de Antígona. A abrir a significativa série de recriações desta antiga história surge um texto dramático - panfletário de António Sérgio, publicado clandestinamente no Porto, em 1930. Esta releitura, que explora toda a retórica de protesto da Antígona sofocliana, virá a ter ainda duas outras versões completamente remodeladas uma de cerca de 1950, ainda inédita e infelizmente incompleta ${ }^{1}$, e outra, muito breve, de 1958, que não incluiremos neste nosso estudo, por serem escassas as alegorias espaciais ${ }^{2}$.

Aproveitando o essencial do drama grego, Sérgio, num permanente jogo de implícitos e de máscaras, debate temas sociais e políticos do segundo quartel do séc. XX português, dominado ora pela ditadura militar ora, sobretudo, pelo

\footnotetext{
${ }^{1}$ Para a datação desta peça ainda inédita, veja-se C. Morais 2007a: 70, n. 6.

${ }^{2}$ Sobre este texto que forma a "Jornada Sexta" do Pátio das Comédias, das Palestras e das Pregaçôes, onde o autor recria apenas as três primeiras cenas do original grego, precedidas de um prólogo e seguidas de um epílogo exegético, vide C. Morais 2007a e 2007b.
} 
consulado salazarista. E, em perfeita sintonia com o ambiente trágico, situa essas questões em espaços e paisagens da Antiguidade Clássica, criteriosamente seleccionados e logicamente relacionados entre si, de molde a serem entendidos como figurações alegóricas da realidade sociopolítica nacional e também europeia.

Em Tebas das Sete Portas, polis que, na $1 .^{\mathrm{a}}$ edição, representa o Portugal de finais dos anos vinte, situa-se o conflito nuclear da acção entre Antígona e Creonte, que reproduz o debate ideológico, suscitado pela instauração do regime ditatorial, a 28 de Maio de 1926. A filha de Édipo, ao opor-se às determinações arbitrárias de seu tio, advogando não a ordem que vem da espada, mas a que "vem da alma, (...) da justiça, do respeito mútuo, do trabalho magnânimo para bem do povo" (1930: 56), converte-se em símbolo da liberdade e dos princípios luminosos da democracia. Creonte, criptónomo de Carmona, personifica, por seu turno, o despotismo e a arbitrária política da força (1930: 36), que não olha a meios para assegurar a manutenção do poder. Tal desiderato consegue-o pela neutralização de todo e qualquer foco de oposição, pela instauração de uma censura e de uma vigilância policial apertadas, e ainda pela contra-informação, que visa, através de boatos e calúnias, desacreditar os seus opositores junto da opinião pública, como se pode verificar por esta ordem dada a Ortágoras (1930: 48):

CREONTE: Faz espalhar pela cidade — mas com jeitinho, entendes? - mais umas mentiras sobre os exilados. Por exemplo: que temos provas nas nossas mãos - mas provas decisivas, incontestáveis — de que eles receberam das mãos dos Citas... Que te parece?... Três milhões?... Quatro milhões?... Quatro milhões, hein?... Quatro milhões, não achas? Isso: que receberam dos Citas quatro milhões. Provas ali, incontestáveis! (esfregando as mãos) Ab! Ab! Vai ser de efeito, hein? (baixo) Claro, forja tu as provas.

Porquê esta referência aos povos da Cítia? O que terá orientado Sérgio para a escolha deste espaço tão recôndito, ausente do original grego? Se considerarmos que a Cítia era o nome dado pelos gregos ao território que se localizava na Europa oriental, entre os Cárpatos e o rio Don, mais concretamente numa zona que, nos finais da terceira década do séc. XX, pertencia à União Soviética, torna-se evidente que estas "mentiras sobre os exilados", sugeridas por Creonte, reproduzem os boatos postos a circular pelo Jornal Imparcial, em 4 e 5 de Julho de 1927. De acordo com essas notícias forjadas, das quais se defendeu, indignado, o nosso autor, em alguns dos seus escritos, "os emigrados políticos, os chefes sinistros dos bandos a quem Portugal esteve entregue durante dezasseis anos de escândalos" e que, nesse momento, viviam em liberdade, "num exílio endinheirado”, tinham recebido, por intermédio de António Sérgio, quatro milhões de francos de origem bolchevista, para que o regime comunista fosse instalado em Portugal (cf. Oliveira Marques 1976: 76-84). Assim, a repetição deste refrão dos 'bolchevistas', metaforicamente denominados 'Citas', faz eco de uma estratégia da ditadura militar que tinha como objectivo atemorizar 
as populações com o fantasma do comunismo, que intencionalmente era identificado com os exilados e com todos os democratas.

Ao servir-se desta "léria do bolchevismo", o governo, na opinião de Sérgio, tornava os portugueses escravos de Espanha, atendendo a que, como escreve, "a própria ideia desta ditadura - com a sua bruta supressão de liberdade de pensamento - fora já de si uma espanholada” (Oliveira Marques 1976: 145). Este contra-argumento do perigo espanhol, agitado pela oposição, tinha alguma razão de ser. De facto, se a génese das duas ditaduras apresentava semelhanças, quer ao nível das causas quer ao nível das ideias, lógico seria que, entre elas, houvesse convergência, nomeadamente em questões estratégicas. É isso que transparece destas palavras de Creonte que reproduzem e confirmam os mais profundos receios de António Sérgio. Na eventualidade de nova revolta que pusesse em perigo o seu poder, o tirano afirma contar com o apoio imediato do seu vizinho, Lisandro de Orcoménia (1930: 67):

CREONTE: Nova revolta? Não creio. A espionagem vela, e faz bom serviço. Eles estão sem força, quebrados de todo... Lisandro de Orcoménia prometeu apoiar-me. Se fosse necessário, em poucas horas, com as suas tropas, chegaria a Tebas...

Neste permanente jogo de máscaras, o topónimo que acompanha este nome de ressonâncias gregas, significativamente arquitectado pelo autor, deve associar-se, em nossa opinião, a Orcómeno, cidade grega da Beócia, região contígua a Tebas. Se, na nossa Antígona, Tebas corresponde a Portugal, lógico será concluir que Orcoménia alude à vizinha Espanha, personificando assim Lisandro aquele que a governou ditatorialmente de 1923 a 1930, ou seja, Primo de Rivera. Em sua substituição, ascende ao poder o general Dámaso Berenguer, encarregado por Afonso XIII de promover a transição da ditadura para a normalidade constitucional. Este acontecimento político terá de tal modo desencadeado uma onda de esperança entre os exilados e os democratas que Sérgio, na sua peça, o transforma simbolicamente no motivo que vai conduzir a acção dramática a um desenlace eufórico, de exaltação dos valores da democracia e da liberdade, bem diferente do que encontramos no original grego.

Inovador, o acto III passa-se num cenário bucólico, povoado por personagens saídas dos Idílios de Teócrito, que, num dia de Primavera luminosa, junto ao "grande desfiladeiro da caverna da cova" (1930: 81), entoam melopeias rústicas. Ao recriar, ainda que de forma muito livre, versos do poeta de Siracusa, colocando-os na boca de Títiro e Córidon, Sérgio constrói um locus amoenus que simboliza a paz e a liberdade a que aspiravam todos os democratas e opositores da ditadura, e que prepara a mensagem de esperança com que termina a peça. 


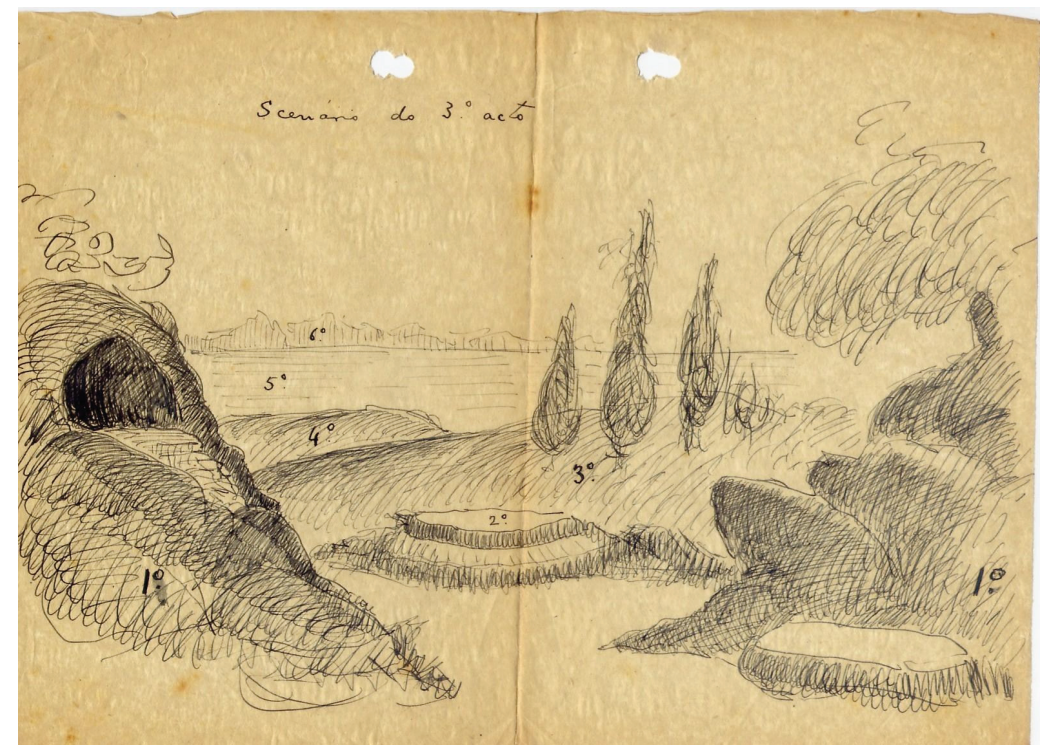

Fig. 1: desenho do cenário do acto III, feito por Sérgio

Preocupado com as consequências que a mudança política em Orcoménia podia trazer para o seu poder, Creonte decidira enviar Antígona para aquele local, porque, num momento conturbado como o que se vivia, a sua presença na cidade podia ser perigosa, atendendo às simpatias de que gozava entre o povo. Entretanto, acautelando os seus interesses, tratou de preparar dois caminhos possíveis para que, no momento oportuno, pudesse escolher o que melhor se adequasse à evolução dos acontecimentos. Se o regime ditatorial conseguisse dominar a situação, seriam intensificados os mecanismos repressivos e Antígona seria encarcerada viva na caverna, espaço onde se consumaria a sua morte. Se vencessem os democratas, a jovem filha de Édipo serviria de refém para negociar a transição.

Um erro na análise da situação leva Creonte e os seus apoiantes a considerarem dominados todos os focos de oposição. Assim, conforme o planeado, Antígona é sepultada viva, tal como acontecera no arquétipo. Quando, entretanto, chega a notícia de que a revolução comandada pelo generoso Hémon e por Critóbulo afinal havia vencido, tendo Creonte abandonado o poder e o país, já nada havia a fazer. Hémon acaba por suicidar-se ao lado de Antígona já morta. $\mathrm{Na}$ morte, porém, alcançam a liberdade por que lutaram e que doaram a Tebas, onde se institui uma democracia generosa, magnânima, tolerante e liberal, dedicada a Palas, "a persuasiva, deusa da luz e da liberdade" (1930: 123).

Contrariando a mensagem final de Critóbulo de esperança num futuro melhor, inspirado na "santidade de Antígona" (1930: 122), a ditadura, volvidos vinte anos, persistia ainda, mas agora moldada à figura e pensamento político de Salazar. Os ventos de mudança em Espanha, com o fim do consulado de 
Primo de Rivera, acabariam por não desencadear a ansiada mudança política em Portugal. De igual modo, a onda de democratização que varreu a Europa, saída da Grande Guerra, não lograria abalar as estruturas do Estado Novo.

Assim, com o nítido objectivo político-pedagógico de espicaçar as consciências, que progressivamente se deixavam tomar pelo torpor, Sérgio, cerca de 1950, retorna à sua Antígona. Porém, este renovado "diálogo histórico-filosófico-político em forma dramática”, como o designa, ficaria inédito, tendose perdido, entretanto, metade da segunda parte do acto II, ou seja a altercação de âmbito ideológico entre Creonte e Hémon, e a quase totalidade do acto III. Pelo elenco, contudo, somos levados a pensar que a sequência dramática desta parte final não seria muito diferente da que encontramos na $10^{a}$ edição.

O que nos resta deste dactiloscrito, além de comprovar as inegáveis e constantes preocupações cívicas do autor, permite-nos verificar que, não obstante a mudança de actores na cena política nacional e internacional, as alegorias espaciais são sensivelmente as mesmas. Tebas é o Portugal de finais da primeira metade do séc. XX. A Cítia continua a representar a barbárie oriental (cf. c. 1950: 47), ou seja, a Rússia e o comunismo, ideologia com que continuam a ser conotados todos os opositores do Estado Novo. A Espanha, governada por Efrâncoras, surge agora simbolicamente situada não em Orcoménia mas na Fócida, região vizinha da Beócia (c. 1950: 61, 144).

Neste cenário alegórico, as personagens, embora investidas de novas funções, de acordo com a alteração dos temas tratados, são praticamente as mesmas, tal como é o mesmo o cerne do conflito trágico. A máscara do tirano grego continua a ocultar Carmona, mas agora convertido em símbolo da ditadura fascista (c. 1950: 4), que, durante anos, contou com o "apoio inconcusso de todos os governos de autoridade e de força - o do Mussilandro, o do Efrâncoras, o do Petenião, o do Hitlérides" (c. 1950: 48)3․ Uma ditadura que foi resistindo ao desgaste do tempo, graças à censura, aos instrumentos de tortura, aos campos de morte lenta (c. 1950: 61), à espionagem e delação (c. 1950: 48, 50), ao controlo dos movimentos suspeitos da oposição pela polícia política, comandada pelo oficial Ortágoras, que assim passa a desempenhar papel diferente do que lhe fora atribuído na $1 .^{\text {a }}$ edição. Para além desta instituição de base, própria de todos os nazi-fascismos, como escreve Sérgio (c. 1950: 4), o regime conta ainda com o apoio da hierarquia católica na promoção do fenómeno de "Fátiras" e das "materialidades do [seu] culto" (c. 1950: 73), que, alimentando a superstição do povo, ajudam a mantê-lo subjugado. Referido de forma jocosa, este espaço religioso (Fátima) simboliza, assim, a comunhão de interesses entre o Estado e a Igreja, como deixam perceber estas palavras da filha de Édipo (c. 1950: 72-73):

ANTÍGONA: A acreditar [nos milagres], Creonte... só naqueles que se passam nas consciências dos homens, no seu interior. Naqueles que consistem em espiritualizaçôes das almas. Quanto

${ }^{3}$ Referências paródicas aos grandes ditadores europeus, que estiveram à frente dos destinos de Itália (Mussolini: 1922-1943), de Espanha (Franco: 1939-1975), da França (Pétain: 19401944) e da Alemanha (Hitler: 1933-1945). 
aos outros... queres que te diga?... parecem-me sortes de prestidigitação pueris, como o do sol em Fátiras a girar à doida, qual roda de um carro (...) Tristes superstiçôes e materializaçôes mesquinhas, a que se agarra a boçalidade das multidões ineptas!... Superstiçôes que cultivas, porque te convém cultivá-las!

Para a promoção da sua ideologia na família e na sociedade, a ditadura serve-se ainda de organismos basilares como a Mocidade Tebana e a Propaganda-Política, dirigida por Nicócoras, criptónimo paródico de António Ferro. Responsável pelo SPN/SNI, desde a sua fundação em 1933 até 1949, o autor de Salazar: o Homem e a sua Obra foi o principal mentor da designada "Política do Espírito» (cf. c. 1950: 32), que tinha como objectivo primordial glorificar o regime e o seu chefe máximo, Ceréfilo, o "novo Homero", o "poeta das cifras", "o feiticeiro dos saldos" (c. 1950: 32, 44).

Nunca subindo ao palco fictício onde os actores são ideias, Ceréfilo - o que gosta de Ceres, deusa da agricultura e das colheitas - é recorrentemente invocado, no decurso da acção. À semelhança da deusa que empresta o seu nome à formação deste antropónimo, também a álgida figura que se oculta por detrás dele (i.e. Salazar) é, para os seus opositores, como se depreende destas palavras de Antígona, o campónio tacanho, que impiedosamente colhe os tributos do povo, com o objectivo de a todo o custo conseguir obter o saldo nas contas públicas de Tebas, sendo incapaz de apreciar a dignidade do espírito, o amor da verdade (c. 1950: 94 b-c):

ANTÍGONA: Com sua alma tacanha de cultivador de aparências, de calculador astucioso, é incapaz de apreciar a dignidade do espírito, a profundez da consciência, o largo voo idealista, o amor da verdade, da sinceridade e da luz. Sem humanidade e sem chama, delicia-se à grande na concupiscência do mando, e para poder deliciar-se na concupiscência do mando consente e encobre todas as malversaçôes dos seus homens. A podridão mascarada é o seu ideal de politica.

Contra esta "podridão mascarada", contra o despotismo de Creonte/Ceréfilo que a todos asfixia, ergue-se a heroína sergiana, guiada pela luz clara e livre do Espírito, da Razão (Sérgio 1958: 21-22). Na defesa dos princípios luminosos da democracia, ela encarna agora, nas palavras do autor, inscritas no prólogo, uma "faceta de anti-fascismo, de aspiração à liberdade, de revolucionismo social" (c. 1950: 4). Destarte, ela é a voz de Sérgio que, através de uma teia alegórica de relações entre espaços e figuras dramáticas saídos da Antiguidade Clássica, se insurge, sempre com intuitos demopédicos, contra as ditadutas militar e salazarista.

\section{Bibliografia}

A. Ferro (1933), Salazar: o Homem e a sua Obra. Lisboa.

A. H. Oliveira Marques, dir. (1976), A Liga de Paris e a Ditadura Militar (19271928). A questão do empréstimo externo. Lisboa. 
C. Morais (2001), "A Antígona de António Sérgio: 'um estudo social em forma dialogada", in C. Morais (coord.), Máscaras Portuguesas de Antígona. Aveiro 13-38.

(2007a), "A dramatização do mínimo essencial do mito de Antígona em António Sérgio", Forma Breve 5 67-76.

(2007b), "Un exercice d'actualisation et d'exégèse du mythe d'Antigone (António Sérgio, Jornada Sexta do Pátio das Comédias, 1958)", in Antigones Contemporaines (de 1945 à nos jours). Clermont Ferrand (no prelo).

F. Rosas (1994), História de Portugal (dir. José Mattoso). VII. O Estado Novo (1926-1974). Lisboa.

A. Sérgio (1930), Antígona. Drama em três actos. Porto.

(c. 1950), Antigona, 2. ${ }^{\text {a }}$ edição remodelada, inédita.

(1958), Pátio das Comédias, das Palestras e das Pregaçóes. Jornada VI. Lisboa. 
(Página deixada propositadamente em branco) 


\title{
O MUNDO CLÁSSICO NAS VIDAS APÓCRIFAS DE AMADEU LOPES SABINO: ALGUNS PARALELOS IMAGINADOS
}

\author{
Glaucianne Silva dos Santos Heuer \\ Universidade Federal do Paraná
}

\begin{abstract}
The book Vidas Apócrifas, by Amadeu Lopes Sabino, comprises five novels which, in common, describe the tragic destiny of characters who, confronted with the search for a meaning for their multiple lives, are protagonists in more or less fabulous adventures taking place in distant and sometimes exotic countries. In the novels $O$ Silêncio and $A$ Sibila de Badajoz, the scenarios of war set the tone of these adventures, which evokes elements of classical culture to compound them and compare them. Furthermore, in Os tesouros de Alexandre, a kind of postscript, the life of Alexander, whose biography is told in Parallel Lives, by Plutarch (to whom the narrator owes the leitmotif that links the various Vidas Apócrifas), is joining the common lives of the characters of these novels. Therefore, the purpose of this text is to point out some imagined parallels between the classical and contemporary worlds in these first two novels.
\end{abstract}

Keywords: Classical word, contemporary word; Parallel Lives, Vidas Apócrifas.

Palavras-chave: Amadeu Lopes Sabino palavra clássica, palavra contemporanea, Vidas Apócrifas, Vidas paralelas.

O livro Vidas Apócrifas ${ }^{1}$, do escritor português Amadeu Lopes Sabino, reúne cinco novelas que, em comum, descrevem os destinos trágicos de personagens que, confrontadas pela busca de um sentido para as suas vivências múltiplas, são protagonistas de aventuras mais ou menos fabulosas decorrentes em países mais ou menos longínguos, algumas vezes exóticos. Nas novelas "O Silêncio" e a "A Sibila de Badajoz", os cenários de guerra dão a tonalidade dessas aventuras errantes, que evocam elementos da cultura clássica para compôlas e cotejá-las. Em "A Nau Perfeitíssima”, "O Lobo Eterno" e "O Violino", também o mundo moderno das personagens reflete o mundo greco-romano, relacionando-os. Deuses (Zeus, Hermes, Dionísio...), bem como poetas (Virgílio, Homero, Lucrécio...) e personagens da mitologia clássica (Electra, Adamastor, Antígona...) percorrem as páginas dessas novelas contemporâneas. Assim sendo, o objetivo deste texto é o de apontar alguns paralelos imaginados

\footnotetext{
${ }^{1} \mathrm{Em}$ todas as citações referentes ao livro, indicarei entre parentêses apenas a página dessa edição.
} 
entre os mundos clássico e contemporâneo nas duas primeiras novelas do livro, estabelecendo pontes entre ambos os mundos.

$\mathrm{Na}$ novela "O Silêncio", o narrador descreve a trajetória de Ramiro Horta, personagem português que, vivendo a infância e juventude no Portugal salazarista, quando adulto radica-se nos Estados Unidos, passando depois a Israel e Jordânia, por onde segue errante em busca da língua de Babel.

As aventuras de Ramiro são acompanhadas e também experimentadas, de Portugal, pelo amigo de infância e "alter ego", Artur Fernandes. Aliás, a narrativa inicia-se com o anúncio da morte de Ramiro Horta em Aqaba, em telegrama recebido pelo amigo em Portugal:

“(...) Em parte determinada da terra de ninguém entre Israel e a Jordânia, avançara o outro; morto a tiro, em circunstâncias por esclarecer, à beira do Mar Vermelho, nas areias disputadas pelos povos do Livro." (p. 15).

A partir daí, o que se tem é uma retrospectiva da vida de Ramiro Horta numa epopéia moderna dividida em sete capítulos. $O$ caráter audacioso e imprudente de Ramiro é contrastado desde o início com a personalidade prudente e apática do seu amigo Artur Fernandes. Num diálogo entre ambos, tem-se um exemplo:

- Sinto-me - disse Artur - como aquele sábio que, chegado à beira do rio, se senta numa pedra, assistindo, impávido, à tumultuosa passagem das águas.

- Assistir à passagem das águas? - perguntou Ramiro. - Essa sabedoria interessa-me pouco. Eu quero é atravessar o rio, - E, já versado em latim, adiantou um aforismo:- Audaces fortuna juvat! (p. 19)

O aforismo citado por Ramiro remete o leitor à fala de Turno, o anti-herói de Eneida que, no canto X, disposto cegamente a combater Enéas, incita os seus por meio da mesma frase: "Audazes a fortuna favorece" (Virgílio 2005, Canto X, 283). Aqui se tem uma primeira intertextualidade entre "O Silêncio" e a epopéia de Virgílio. Intertextualidade esta que, estendendo-se ao longo da narrativa, estabelece um ponto de contato bastante estreito entre as sagas de Ramiro Horta e do herói troiano.

O herói moderno decidi-se a "partir para Babel" (p. 59), instalando-se, a partir de fevereiro de 1998, em Bersheva, “(...) na orla do deserto do Negueve, onde, entre o estudo do dativo nas línguas semíticas e os amores com uma semita, que conhecera também em Nova Iorque, vai permanecer treze meses" (p. 66-67). E enquanto Ramiro vagava pela região de Aqaba, Artur Fernandes, em Portugal, sofria pela falta de notícias do amigo:

Perdido no deserto - eis a conclusão pessimista do semprepessimista Artur Fernandes. Substituía um colega doente, professor de Latim, e no destino de Eneias inscrevia o de Ramiro:

Musa, mibi causas memora, quo numine laeso, 
Quidve dolens regina deum tot volvere casus

Insignem pietate virum, tot adire labores,

Impulerit. Tantaene animis caelestibus irae!

$<$ Oh, musa!> - lastimava-se Artur, na solidão da Boca do Vento, os olhos marejados de lágrimas, o retrato de Ramiro nas mãos trémulas, <como épossivel que a infelicidade persiga este principe magnânimo, humano e piedoso? > Ia à cozinha preparar mais um uísque, fazendo os possiveis por não despertar Cecilia, que dormia no quarto do casal. A actriz regressara a Almada, à Boca do Vento e ao teatro independente português com a ferida aberta do abandono e da traição, $e$ não queria ouvir pronunciar o nome do ex-amante americano. <Como estão repletas de fel as almas dos deuses e das deusas! > suspirava Artur, contendo os soluços. (p. 71)

Assim como Enéas abandonara Dido para seguir a sua missão determinada pelos deuses, deixando-a furiosa, Ramiro Horta abandonara Cecília nos Estados Unidos para ir em busca do seu tesouro. Isto é, determinado a seguir Samira, a semita que ele conhecera em Nova Iorque. No entanto, deve-se mencionar que, diferentemente do piedoso Enéas, o qual é movido pela obediência ao Fatum e não pela sua própria vontade, Ramiro, destemido e audacioso, é dotado de um caráter hedônico e preza pela liberdade de espírito, cumprindo os seus desejos e as suas ambições como a um dever e exaltando um despojamento que o abre a novas experiências de si.

Além disso, tal qual o herói troiano Enéas, que desce aos infernos, no canto VI da Eneida, acompanhado pela Sibila, personagem mitológica dotada de poderes proféticos, Ramiro Horta, para cumprir a sua saga, acaba também por descer aos infernos. E, ali, o protagonista depara-se com seres míticos que compõem o quadro dos monstros infernais avistados também por Enéas:

Os povos do deserto - admitiu Ramiro - submetem-se de tal maneira aos desígnios da divindade que, fechados do mundo, condenados ao pensamento abstracto pela imensidão do espaço, entendem a sua própria violência como parte integrante da justiça do Senhor. Manteve-se desperto durante horas, deitado num leito de trapos e excrementos de animais, tentando alcançar a razão dos urros dos camelos, adivinhando o dardejar de adagas e punhais, inseguro no meio daquela turba imune à compaixão e à tolerância. Na modorra entre o sono e a vigilia, vislumbrou, no simulacro das formas da noite, a Hidra cujas cabeças sopram ventos de peçonha, a Quimera que lança turbilhóes de fogo, a terrivel Górgona, a ávida Harpia (...) (p. 89)

No entanto, ao contrário do que se passou ao herói troiano, o "herói” dessa epopéia moderna, perdido no meio dos povos do deserto, não consegue tornar atrás e à luz, eternizando-se nas areias da linha militarizada que separa Israel 
da Jordânia. Morto pelo tiro certeiro da arma de Samira, a "donzela-guerreira"2 vestida de homem.

A saga de Ramiro Horta é determinada pelo livre-arbítrio, isto é, sem uma moral familiar, uma crença religiosa e sem mesmo um sentimento de dever para com a pátria. Há apenas o compromisso com a liberdade individual. Desta forma, a saga de Enéas, indivíduo que é nação e que é pátria, ligado a ela numa missão, na qual a vontade subjetiva deve submeter-se a uma lei superior que rege os destinos, contrasta com a do sujeito moderno, o qual empreende uma busca individual e não mais coletiva, numa sede de confronto com os modelos de totalidade. Os fragmentos da Eneida evocados por Ramiro e Artur, refletem, como num espelho invertido, a grandeza e a precariedade, a totalidade e a fragmentação, o apolínico e o dionísico.

O mesmo tema é retomado ao longo das Vidas Apócrifas, Por exemplo, na "A Sibila de Badajoz", que narra a história da vida e morte de Álvaro Carneiro, personagem aventureiro que:

(...) gastou a juventude nas confabulaçôes da I República portuguesa. Estudou Medicina em Coimbra, aproximou-se dos anarquismos politicos e literários, financiou conspiratas e pronunciamentos. Percorreu Europas e Américas e talvez tenha conhecido Lenine em Genebra. Em 1928 publicou no Rio de Janeiro um poema épico que, em dez cantos, celebrava a fraternidade universal. Mais tarde fixou-se em Itália, país onde, entre deuses e sátiros, se sentia em casa. Em 1934, num rompante voltou a Portugal (...) (99-100)

$\mathrm{Na}$ sequência desta narrativa, o relato indireto do narrador dá lugar ao relato direto do padre Joseph Valls, que conhecera Álvaro Carneiro em Nápoles, nos anos 30. O relato feito em 1968 a Mateus Leal, vai esclarecer as lacunas da biografia e as circunstâncias da morte de Álvaro Carneiro. Trata-se de uma tragédia narrada em dois atos que envolve o conflito de Álvaro Carneiro e do próprio padre Valls com os padrões doutrinários da época, apontando para a fragmentação do sujeito, partilhado entre Apolo e Dionísio, na relação entre subjetividade e o Absoluto.

A ilha de Capri, um dos cenários do primeiro ato da tragédia narrada, evoca a mitologia imperial, relacionando-a com o mundo moderno, neste caso, o fascismo de Mussolini:

O professor Torelli fora maçónico na juventude e, embora se tivesse acomodado, colaborando (apenas enquanto arqueólogo, precisava) no restabelecimento da herança romana de que o Duce fizera uma das grandes tarefas da Ditadura, defendia em privado propósitos de tolerância. Teria

${ }^{2}$ A personagem Samira remete para Camila, a guerreira de Eneida. No entanto, o seu disfarce masculino recupera o tema do romance tradicional Donzela que vai à guerra, cujos versos são citados ao longo da narrativa. 
preferido manter-se à margem da recuperação fascista da mitologia imperial (...) (p. 117)

Tal recuperação incluía a residência de Tibério, o segundo imperador romano, sucessor de César Augusto. Imperador de Roma de 14 à 37 d.C., Tibério, afastando-se de Roma, buscou refúgio na ilha de Capri, de onde governou até o fim dos seus dias. De acordo com Suetónio, em Os doze césares, Tibério, na ilha, (...) "Mercê de uma solidão que lhe permitia inteira licença e por assim dizer o escondia dos olhares de Roma, entregou-se, por fim, completamente, a todos os vícios que por muito tempo mal dissimulara (...)" (Suetónio 2007: 184-185).

Em "A Sibila de Badajoz", a relação de Mussolini e seu fascismo com a mitologia imperial, representada aqui pela figura de Tibério, permeia toda a narrativa do padre Valls:

Perdi-me na contemplação dos despenhadeiros marinhos que envolvem a ilha. Tentei imaginar as ninfas e os sátiros de Tibério, entoando cânticos ao prazer è alegria. Mas depressa o crepitar das metralhadoras me ocupou a mente. Não era apenas o Vesúvio que ameaçava explodir. Toda a Europa oscilava entre a sedição e o precipicio. Os aventureiros chegavam ao poder nos partidos e nos Estados, apossavam-se dos arsenais, prometiam o Paraíso. Ora o Paraíso é, há que admiti-lo, a mais perigosa das utopias (...) (p.126)

Assim, "inapto para abraçar ideologias" e, consequentemente, inqualificado "para as práticas colaterais da obediência cega, da adulação e do espírito do corpo" (p.132), o padre Valls, identificando-se com Álvaro Carneiro e a sua liberdade de espírito, vive um conflito com o seu próprio tempo, marcado pelo desejo desmedido do fascismo com "a realização moderna do ideal clássico" (p.133), conforme se observa no relato do seu diálogo com Álvaro Carneiro:

(...) Disse-lhe (...) que a História não é um caminho sem escolbos em direç̧ão à felicidade dos povos, e que o retrocesso civilizacional é possível. Falei-lhe da ideia nietzschiana do equilibrio entre o deus <masculino> do sublime e da tragédia, Apolo, e o deus <feminino> da loucura e da incandescência, Dionísio. Eu queria acreditar no mistério desse equilibrio; a meu ver, o absurdo consistia na predominância de Dionísio, no reino da desmedida, da desrazão e da loucura: no regresso das civilizaçôes às cavernas. (p.134)

Transferindo da Itália para a Espanha, em 1936, na cidade de Badajoz, o padre Valls é encarregado pela Companhia de "organizar a protecção dos arquivos dos jesuítas na Espanha dizimada pela guerra civil" (p.141) e a crueldade da guerra faz com que ele reflita:

(...) Entre o horror e a incomunicabilidade, interrogava-me qual seria o meu papel naquela carnificina: espectador, parte interessada, cúmplice ou autor moral? (...) A guerra promoverame a confiscador de tesouros (...) Uma noite, desanimado, admiti que a Divina Providência 
me desprezava, adestrando na minha pessoa a crueldade dos Antigos e a indiferença dos Modernos. (p. 148)

$\mathrm{E}$ foi assim que, em meio à barbárie da guerra, perseguindo tesouros, o padre reencontrou o seu "alter ego", Álvaro Carneiro, na fronteira entre Portugal e Espanha. E, para reaver um quadro de Zurbarán (1598-1664), de uma figura feminina, "santa, feiticeira ou sibila" (p.150), que Álvaro Carneiro tanto desejara e que agora possuía, o clérigo, cumprindo o seu papel na guerra, dá o tiro que põe termo à vida daquele aventureiro português: "(...) Fechei os olhos e disparei, como a criança que comete o primeiro pecado (...) (p.161)”.

$\mathrm{Na}$ busca destes paralelos imaginados, cabe ainda apontar aqui que, na cultura clássica, a Sibila, dispondo de dons proféticos, era a figura portadora da vontade dos deuses, isto é, do óraculo que dava a conhecer o futuro e o destino das gentes e das terras. Como já mencionado, a Sibila é quem orienta e acompanha Enéas em sua descida aos infernos. Entretanto, a figura da Sibila que tanto Álvaro quanto o padre Valls enxergam no quadro de Zurbarán simboliza o fantasmagórico na busca de um óraculo sibilino no mundo contemporâneo, isto é, simboliza o desejo de uma voz divinatória inaudita.

Desta forma, percebe-se que para além deste entrelaçar o mundo clássico e o mundo moderno, Lopes Sabino apresenta os destinos trágicos de personagens que, desafiando as convenções doutrinárias dos seus Estados e dispondo-se a recusar os cânones estabelecidos, acabam por tornarem-se aventureiros, de acordo com a própria confissão de padre Valls:

Enquanto esperava, fui pensando que o meu desejo de desafiar as convençôes começara por me promover a explorador de tesouros e conseguira, finalmente, fazer de mim um aventureiro. O propósito arrogante de encontrar Deus na recusa dos cânones estabelecidos conduzira-me à beira da perdição. No meio do desalinho das mentes, da

entrega do destino dos homens à violência e à morte, o meu espírito estava prestes a soçobrar na indiferença, que é o pior dos pecados da modernidade. (p. 151)

As viagens são a grande metáfora da existência humana enquanto aventura errática e os embates entre a prudência e a transgressão dos limites, entre "o ascetismo do espírito" e o "júbilo da carne" (p. 135), representam o eterno paradoxo da Humanidade; por isso, como diz o narrador-autor, "os personagens centrais dessas Vidas..., experimentam a capacidade de vivências múltiplas: de preferência apenas duas em simultâneo, porque, como defendia Baudelaire, a coabitação de mais do que duas realidades - ou mais do que duas idéias contraditórias provoca a catástrofe cívica e pessoal, ou, o que é bem pior, a apoplexia poética (...)”(p. 276).

Para finalizar, acrescente-se ainda que, em "Os Tesouros de Alexandre", uma espécie de Posfácio, a vida de Alexandre e a duplicidade da existência do monarca macedônio, cuja biografia é narrada nas Vidas Paralelas, de Plutarco (a quem o narrador deve o fio condutor que cose as várias Vidas Apócrifas), se 
une às vidas das personagens comuns dessas novelas, criando os paralelos. De acordo com Félicien, personagem da novela "O Violino", "Para pintar as paixões dos novos tempos (...) é preciso encontrar novos verbos e novas imagens. Para falar e comover os homens do presente, são necessárias palavras e figuras nunca antes utilizadas (...)"(p. 237). Por sua vez, Amadeu Lopes Sabino, contrariando a sua personagem, busca nas palavras e figuras do mundo clássico, os novos verbos e as novas imagens para pintar as paixões do mundo contemporâneo. Num movimento cíclico que representa o eterno retorno da História, Vidas Apócrifas retoma as questões de identidade, alteridade e transitoriedade, bem como apresenta ao leitor uma reflexão em torno da contradição indissolúvel e trágica da existência humana e em torno das cruéis desmedidas que as ideologias apresentam ontem, hoje e sempre.

\section{Bibliografia}

Amadeu Lopes Sabino (2005), Vidas Apócrifas. Lisboa: Dom Quixote. Suetónio (2007), Os doze Césares. Lisboa: Biblioteca Editores Independentes. Virgílio (2005), Eneida. São Paulo: Ateliê Editorial. 
(Página deixada propositadamente em branco) 


\title{
OBSERVAC̃̃O FILOSÓFICA E CONTEMPLAČ̃O POÉTIĆA DAS PAISAGENS EM LUCRÉCIỎ
}

\author{
Andrés Pociña \\ Universidade de Granada \\ apocina@ugr.es
}

\begin{abstract}
Resumen
El paisaje, tanto físico como humano, es lógicamente un elemento esencial en los seis libros de De rerum natura, el poema sobre la naturaleza de Lucrecio. El poeta se ocupa con gran frecuencia de diversos paisajes, enfocándolos de forma distinta desde el punto de vista literario, cuando lo hace movido por un interés esencialmente filosófico o por un motivo estético. Se recuerdan brevemente tratamientos de paisajes en el poema lucreciano como encuadramientos (1. 1-25), para evocar la relación hombre y paisaje (1. 62-79), la relación mundo y paisaje (5. 783-796), algunos paisajes notables (2.317-332), paisajes reales de interés (1.716-730), y, por último, una aproximación al paisaje amado por Lucrecio (1. 926-930); 2. 29-33).
\end{abstract}

Keywords: landscape, Lucretius, philosophy, poetry.

Palavras-chave: filosofia, Lucrécio, paisagem, poesia.

1. Paisagens em De rerum natura.

“...Doch seine scharfe Beobachtungsgabe, seine fesselnde Argumentation und seine Sprachkraft haben nichs von ihrer Frische eingebübt.Mehr denn je scheint es an der Zeit, den Dichter in Lukrez wiederzuentdecken. Es hat der römischen Poesie und dem lateinischen Wort geistige Höhen erschlossen, die für sie bisher unzugänglich waren..."1.

Regresso a uma leitura de Lucrécio com a mesma citação de Michael von Albrecht com que antes abri uma conferência sobre a paixão do poeta pelos animais, que apresentei no V Congresso de Estudos Clássicos, celebrado em Cádis há menos de dois anos ${ }^{2}$. Também neste caso me move a concordância com o grande latinista alemão, quando afirma que 'mais do que nunca parece ser este o momento de redescobrir em Lucrécio o poeta', não sem acrescentar

${ }^{1}$ M.von Albrecht (1994), Geschichte der römischen Literatur. München, p. 254 s.

2 "Otra lectura de Lucrecio: su pasión por los animales", conferência apresentada no V Congresso Andaluz de Estudos Clássicos, Faculdade de Filosofía e Letras de Cádis, Outubro de 2006. 
que mais uma vez devemos procurar nele não apenas o poeta, mas também o filósofo, o ideólogo, o moralista, o homem íntegro. Esta é uma ideia que há muito já defendi num breve artigo de divulgação, em que unia Epicuro e Lucrécio sob a legenda 'dois solazes sólidos para rematar um século agitado’3.

Devo confessar, antes de prosseguir a minha exposição, que a leitura que faço de Lucrécio, qualquer que seja o ponto de vista, não pode resultar neutra, imparcial, desapaixonada. A leitura comentada do De rerum natura foi, ao longo de muitos anos, uma das ocupações mais frequentes na minha já larga experiência como professor universitário; confesso, com franqueza, que nunca soube fazê-lo sem pôr nesta actividade muita paixão, muito afã, num esforço para transmitir às alunas e alunos, da melhor forma possível, o amor profundo que, desde sempre, senti por Lucrécio e pela sua obra. Neste momento em que eles não figuram, no meu programa de ensino, com a mesma duração e abrangência de outros tempos, aproveito qualquer ocasião que se me ofereça para reflectir sobre um ou outro aspecto concreto. Quando a Associação Portuguesa de Estudos Clássicos e a Universidade de Évora entenderam contar comigo para o seu VII Congresso Internacional, centrado no tema 'Espaços e Paisagens', não hesitei, por um instante sequer, em ocupar-me do tema da paisagem em Lucrécio, de cuja importância tinha absoluta certeza, apesar de nunca sobre ele ter escrito ou publicado fosse o que fosse. Motivou-me ainda o facto de, apesar da abundante bibliografia existente sobre o poeta e respectiva obra, particularmente do ponto de vista ideológico ${ }^{4}$, não ter encontrado estudos específicos dedicados ao tratamento da paisagem no nosso autor.

No entanto, por pouco que meditemos sobre o conteúdo do poema lucreciano, resulta previsível que a paisagem ocupe um lugar de relevo numa obra que, essencialmente, e independentemente das múltiplas interpretações que sobre ela se possam emitir ${ }^{5}$, situa o eixo central do seu interesse na natureza. Os fundamentos do conhecimento na filosofia de Lucrécio são, como ele mesmo se encarrega de repetir em quatro ocasiões idênticas, naturae species ratioque ${ }^{6}$; assim, uma observação da realidade que nos rodeia, seguida

\footnotetext{
${ }^{3}$ A. Pociña (1998), "Epicuro y Lucrecio. Dos solaces sólidos para rematar un siglo agitado”, Archipiélago 34-35 158-162.

${ }^{4}$ Limito-me a recordar as informações bibliográficas de A. Dalzell (1972), "A Bibliography of Work on Lucretius, 1945-1972”, CW 66 (1972-1973) 389-427; 67 (1973-1974) 65-112; L. Perelli (1978), "Rassegna di studi lucreziani (1968-1977)”, BStudLat 8 277-308; C. A. Gordon - E. J. Kenney (1985), A Bibliography of Lucretius. Winchester, (1962 1ª ed.); S. Di Giovine

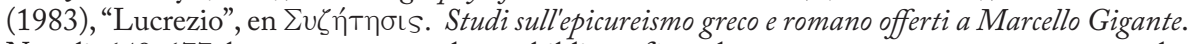
Napoli, 649-677; bem como as excelentes bibliografías selectas que se encontram, por exemplo, em M. von Albrecht, Historia de la literatura romana, vol. I, cit., pp. 309-314; e G. B. Conte - L. Canali - I. Dionigi (eds.) (2000), Tito Lucrezio Caro, La natura delle cose. Milano, 57-75; etc

${ }^{5}$ Neste sentido, quero chamar mais uma vez a atenção, apesar do tempo transcorrido desde a sua publicação, para o precioso livro de B. Farrington (1965), Ciencia y política en el mundo antiguo, trad. esp. de D. Plácido Suárez. Madrid.

${ }^{6}$ Em concreto, segundo a ed. oxoniense de Bailey, em Lucr. 1, 146-148; 2, 5961; 3, 91-93; 6, 39-41, que oferecem, sem variantes, o seguinte texto:

bunc igitur terrorem animi tenebrasque necessest/ non radii solis neque lucida tela diei/ discutiant, sed
} 
da reflexão filosófica sobre as noções percebidas, será o único meio e método válidos para atingir a verdade; mas tendo em conta a forma de escrever de Lucrécio, não imaginamos como poderia ele referir-se a essa naturae species sem recurso frequente à descrição da paisagem.

$\mathrm{O}$ que o nosso olhar percebe daquilo que nos rodeia pode traduzir-se em corpos simples, inanimados ou animados, ou então uns e outros em conjunto, no que compõe a nossa paisagem vital. Lucrécio ama com paixão essa realidade que constitui o objecto fundamental da indagação que faz; perante as paisagens que se oferecem aos seus olhos, adopta duas formas de comportamento claramente perceptíveis: a observação meramente filosófica ou a contemplação e descrição poética. Uma não é incompatível com a outra, pois a atenção filosófica dispensada à paisagem pode facilmente conduzir a um tratamento poético; do mesmo modo que o desenvolvimento poético de uma paisagem costuma ser o complemento e exemplificação idóneos de uma questão filosófica. Mas ambas as formas de tratar a paisagem resultam distintas conforme o ponto de vista literário que se adoptar: a observação filosófica da paisagem costuma realizar-se de forma racional, breve, sem adornos literários; enquanto a descrição poética de paisagens tem habitualmente um desenvolvimento mais amplo, com profusão de pormenores, maior riqueza de vocabulário e de recursos literários, insistência na exaltação dos elementos estéticos. Vejamos dois exemplos que podem evidenciar, melhor do que as minhas palavras, o que pretendo explicar:

a) Descrição meramente física da organização da paisagem natural, no contexto da explicação filosófica da realidade a partir dos pressupostos da física atómica, em 1.998 ss.:

\section{Por último, a nossos olhos é evidente que uma coisa limita a outra; o ar separa as colinas e, ao ar, os montes, a terra póe limites ao mar e o mar, por sua vez, a todas as terras; mas na verdade nada há que, por fora, marque os limites do todo.}

b) Em contrapartida, veja-se esta rápida, mas bem calculada descrição da mudança da paisagem com as estações, sublinhados os seus elementos mais positivos e mais belos através de uma adjectivação altamente poética (uiuida tellus, res teneras ...) e outros recursos literários, em 1.174 ss.:

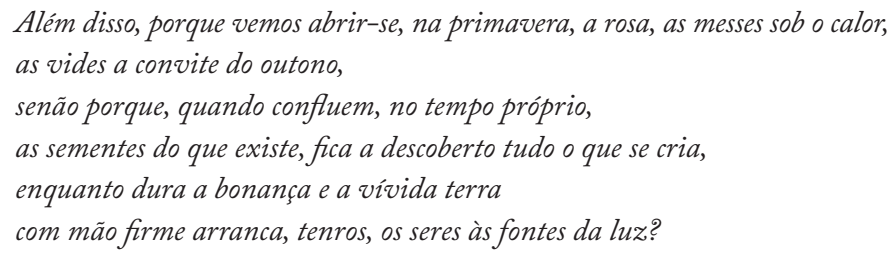

naturae species ratioque. 
Além desta primeira e elementar divisão, no De rerum natura, em paisagens de interesse filosófico e paisagens de interesse poético, seria possível, dada a abundância do material à nossa disposição, estabelecer um tipo de classificação das paisagens lucrecianas; poderíamos então falar de paisagens que enquadram um facto geral ou uma determinada situação (por ex., 1.62-79; 1.1-127); paisagens que servem de marco ao tratamento do homem (por ex., 1.208-214; 5.1241-1249); paisagens que acompanham uma reflexão filosófica concreta (por ex., 1.340-345; 1.998-1007); paisagens que correspondem à concepção lucreciana do locus amoenus (por ex., 1.926-930; 2.23-33; 3.18-24; 4.1-9; 5.1392-1396); etc. Não obstante, seria muito difícil encontrar uma classificação absolutamente convincente, pois fosse qual fosse a que se propusesse implicaria vantagens e inconvenientes vários; por isso, talvez seja preferível prescindir de classificações e centrarmo-nos na análise das paisagens de Lucrécio agrupandoas por semelhança de conteúdo ou de tratamento.

\section{Paisagem como enquadramento no De rerum natura}

Uma das paisagens mais chamativas, das muitas criadas por Lucrécio, é a que encontramos logo na abertura do De rerum natura, ou seja, a paisagem que assinala a surpreendente, sempre questionada e sempre debatida invocação a Vénus, com que o nosso autor decidiu começar um poema de concepção naturalista, claramente iconoclasta, que segregava os deuses como circunstâncias integrantes da realidade e da humanidade. Recordemos a dita abertura, tão polémica como formosa $(1.1-25)^{7}$ :

\footnotetext{
Dos Enéadas mãe, tu que és de homens e deuses alegria,

Vénus criadora! Tu, que animas o deslizar dos corpos celestes, o mar portador de navios, as terras produtoras de fruto, com a tua presença, já que é graças a ti que toda a criatura é concebida, nasce e contempla a luz do Sol! De ti, ó deusa, de ti fogem os ventos, fogem as nuvens do céu à tua chegada; é para ti que a terra laboriosa faz crescer as doces flores; para ti é o sorriso das vagas marinhas e para ti o céu aplacado resplandece, em jorros de luz. Logo que se revela a face da chegada da Primavera, e se soltam as auras criadoras de Favónio, ganhando vigor, são as aves nos ares que primeiro pronunciam o teu advento, ó deusa, de coraçôes inflamados pelo teu poder; de seguida, as feras selvagens e o gado saltam sobre as férteis pastagens e passam a nado os ribeiros velozes - de tal modo os prende o teu encanto,
}

7 Tradução de A. de Mendonça Falcão, Da Natureza das Cousas. Coimbra, Imprensa da Universidade, 1890, apud M. H. da Rocha Pereira (2002), Romana. Antologia da Cultura Latina. Lisboa, 85. O facto de este texto, bem como o que será objecto da nossa atenção mais adiante, terem sido seleccionados pela ilustre professora de Coimbra na sua "Antologia", facilita-me a possibilidade de utilizar neste trabalho a formosa versão de Mendonça Falcão. 
que cada um segue, cúpido, onde quer que te apresses a levá-lo.

Depois, através de mares e montanhas e rios rapaces,

das moradas frondiferas das aves e dos campos verdejantes,

instilando a todos no peito a doçura do amor,

fazes com que, segundo a sua espécie, com volúpia propaguem a raça.

$E$, já que sozinha governas a natureza

e que sem ti nada ascende às claras plagas da luz,

nem nada se torna fértil ou possui encanto,

é a ti que eu anseio ter por companhia ao escrever estes versos

que sobre a natureza das coisas intento compor...

Qualquer que seja a interpretação que se faça da presença de Vénus e da sua polissémica figura, está fora de questão que ela ocupa, a todo o momento, o centro da invocação em toda a sua extensão, do mesmo modo que a imagem da deusa faz confluir, para a sua posição central, os olhos atónitos de quem contempla a 'Alegoria da Primavera' de Sandro Botticelli na Galleria degli Uffizi de Florença, um quadro que sempre se relacionou com a Vénus lucreciana. Pois bem, não sabemos se uma leitura profunda e minuciosa da invocação nos deixa impressa no espírito sobretudo a imagem de Vénus, majestosamente descrita e ricamente adjectivada, ou antes a dos elementos animados e inanimados, configuradores de um quadro de natureza, que se movem em torno da deusa. Começar um poema épico com um louvor à divindade inspiradora era uma exigência da tradição do género desde os poemas homéricos; mas desenvolver, em dezenas de hexâmetros, uma imagem detalhada, e, como atrás afirmei, polissémica, da deusa a que se pede ajuda e inspiração, ou, mais ainda, incluila numa paisagem formosa, de que se supõe que ela é a causa, não tem precedentes na tradição épica anterior a Lucrécio. A adjectivação referente a Vénus, as acções que se lhe atribuem e que provocam a oração do poeta são fundamentais; mas não menos rica é a adjectivação referente à paisagem e aos seres que rodeiam a presença da deusa; fica-nos, assim, a dúvida sobre se o essencial é Vénus, que centra a paisagem, ou a paisagem que valoriza Vénus, tendo em conta que Lucrécio tenta ganhar a nossa adesão para penetrarmos nos caminhos apaixonantes, mas difíceis, do conhecimento da natureza.

A bibliografia sobre a invocação a Vénus que serve de pórtico ao De rerum natura é imensa, e não é este o lugar para a evocar, nem mesmo nos seus contributos mais destacados ${ }^{8}$. No entanto, não se encontra, na habitualmente citada, um texto fundamental, que consiste no parágrafo com que Augusto Rostagni encerra a apresentação de Lucrécio, na sua sempre excelente Storia

\footnotetext{
${ }^{8}$ Recordarei, mesmo assim, o livro fundamental de F. Giancotti (1959), Il Preludio di Lucrezio. Messina - Firenze, em especial a sua útil análise da bibliografía precedente em pp. 152-201. Veja-se ainda E. A. Hahn (1966), "Lucretius' Prooemion with Reference to Sappho and Catullus”, CW 60 134-139; K. Kleve (1966), “Lukrez und Venus”, SO 41 86-97; E. Asmis (1982), "Lucretius' Venus and Stoic Zeus" Hermes 110 458-470; etc.
} 
della letteratura latina9. Vou reproduzi-la aqui por extenso, porque representa na perfeição o que pessoalmente penso sobre o sentido da introdução da paisagem da natureza, como contexto da invocação a Vénus, precisamente nos primeiros versos do grande poema:

\begin{abstract}
"Dunque, anche Venere, nel famoso proemio, è un puro e semplice nome, un pretesto, suggerito dalle necessità della dedica a Memmio, che nella dea, progenitrice dei Romani, aveva la sua patrona. In realtà non è la dea Venere quella che Lucrezio ci raffigura: sono le "belle d'erbe famiglie e d'animali", sono gli astri rotanti nell'azzurro infinito, le navi che solcano i mari, le acque che ridono sotto la diffusa luce del cielo, le greggie che saltano per i pascoli rigogliosi e attraversano le rapide correnti dei fumi, i fiori che ingemmano il suolo, l'alito d'amore e di vita che pervade l'universo in tutte le sue sensibili manifestazioni” (p. 545).
\end{abstract}

Dispensa-se qualquer comentário: Lucrécio, com o pretexto da necessidade imposta pelo género literário de invocar uma divindade inspiradora, cria uma paisagem belíssima em si mesma, mas também animada por formosas criaturas, que estabelece como pórtico ideal do seu poema sobre a natureza.

\title{
3.Homem e paisagem
}

$\mathrm{O}$ amor à natureza move cada verso de Lucrécio, que vê na procura e no conhecimento da verdade sobre a realidade vital a nossa salvação. Mas nessa natureza há uma componente que, muito mais do que qualquer outra, desperta o amor apaixonado de Lucrécio: a humanidade. E utilizando um recurso inteligente, em tudo semelhante ao que vimos antes, isto é, tomando uma invocação a Vénus como pretexto para oferecer um quadro da natureza, pouco depois, nos vv. 1, 62-79, passo que a antiga tradição colhida pelos códices de Leyden ${ }^{10}$ denomina laus inuentoris, Lucrécio apresenta, é certo, o primeiro dos elogios de Epicuro, baseado no apelo à sua valentia perante a força bloqueadora das crenças supersticiosas e na defesa triunfal da realidade, de modo a trazer a verdade, a libertação, ao género humano; pois bem, a impressão que deixa no leitor atento não corresponde precisamente ao retrato ideal do filósofo grego, mas sobretudo à paisagem humana em que se desenvolve o seu labor, a partir de um retrato, desolado e abatido do homem, pisado pela superstição, até ao aparecimento do homem libertado, que, por sua vez, domina a superstição. Trata-se de um dos quadros mais perfeitos que podemos encontrar no $D e$ rerum natura $(1.62-79)^{11}$ :

\footnotetext{
${ }^{9}$ A. Rostagni (1964), Storia della letteratura latina. I. La Repubblica. Torino.

${ }^{10}$ Recordemos que a divisão em capítulos que oferecem os livros de Lucrécio nos referidos códices, mesmo não sendo obra do poeta, parece remontar a uma época muito recuada, talvez mesmo o séc. II; em consequência, deve ter-se presente, porque reflecte, sob certos aspectos, a ideia de uma antiquíssima interpretação do desenvolvimento conceptual do De rerum natura. Cf. H. Fischer (1924), De capitulis Lucretianis. Giessen.

${ }^{11}$ Recorde-se o já clássico estudo deste passo em V. Buchheit (1971), "Epikurs Triumph des Geistes”, Hermes 99 303-323, agora publicado também em versão inglesa, "Epicurus'Triumph
} 
Quando, abjecta, a vida humana jazia aos olhos de todos

sobre a terra, oprimida pelo peso da crendice,

que das celestes regióes exibia a cabeça,

impendendo sobre os mortais com tremendo aspecto,

um Homem Grego ousou, antes de todos,

contra ela erguer os seus olhos mortais

e contra ela foi o primeiro a opor resistência.

A ele não o deteve a fama dos deuses, nem coriscos,

nem o céu com estrondos minazes, mas mais lhe acicatou

do seu ânimo a acérrima força, para ambicionar ser o primeiro

a arrombar as trancadas portas do acesso à natureza.

Ganhou, portanto, a vitória a vigorosa força do seu ânimo,

avançou muito para além das muralhas flamantes do mundo,

e com a mente e o espirito percorreu a imensidade;

dai regressa vitorioso, para nos ensinar o que pode ser

e o que não pode; enfim, de que maneira cada coisa

é sujeita a limites e bem enterrados os marcos que lhes põem termo.

Eis porque a crendice foi calcada aos pés, por sua vez,

$e$ a vitória nos faz subir até aos céus ${ }^{12}$.

O quadro tenebroso que Lucrécio pinta nos primeiros quatro versos resulta magistral: a vita humana encontra-se na situação mais vergonhosa que imaginar se pode, não deitada ou estendida no solo, mas lançada, atirada (iaceret), o que resulta fisicamente inadequado, vexatório (in terris), vergonhoso (foede), causador de opróbrio porque acontece abertamente, à vista de todos (ante oculos); e como se não fosse já bastante, Lucrécio prolonga o desenvolvimento trágico, ao acrescentar não apenas que o homem foi atirado, como também está esmagado (oppressa), e não por um peso ligeiro, mas pela opressão grave e sufocante da superstição (graui sub religione). Tudo isto condensado em dois versos, em que nada sobra ou falta. Em contrapartida, em outros dois, a imagem horrível da superstição, personificada como a mais terrível das gárgolas da catedral parisina, exibindo a cabeça (ostendebat), com horrível carranca (horribili aspectu), ameaçava lançar-se, a qualquer momento, sobre os mortais.

Temos, portanto, a paisagem terrível, que por si só define e qualifica a situação da humanidade. Uma dezena de versos será suficiente a Lucrécio para apresentar e elogiar o labor libertador empreendido por Epicuro, sob forma de um epilion minúsculo, capaz de conter a maior façanha épica, e logo, em dois versos apenas, a subversão total do quadro inicial: agora é a religião quem jaz sob os pés do homem, situação expressa por meio de pedibus subiecta, isto é,

of the Mind (Lucr. 1.62-79)", em M. R. Gale (ed.) (2007), Lucretus: Oxford Readings in Classical Studies. Oxford, 104-131. Também nesta colecção de trabalhos lucrecianos cuidada por Gale pode ver-se um comentário interessante deste passo em D. Kennedy, "Making a Text of the Universe: Perspectives on Discursive Order in De Rerum Natura of Lucretius", 376-396.

12 Tradução de A. de Mendonça Falcão, Da Natureza das Cousas, cit., apud M. H. da Rocha Pereira, op. cit., p. 86. 
com uma forma que evoca o terrível iaceret inicial, mas sem cair na repetição; e se antes de Epicuro essa religio oprimia, com o seu peso, o homem, agora é o homem, vencedor, quem tritura a superstição, como os grãos de trigo sob a pedra do moinho (obteritur). O triunfo do homem grego consistiu em igualar ambas as forças.

\title{
4. Mundo e paisagem
}

À margem dos deuses e dos homens, a terra cria-se a si mesma, na sua origem, pela união dos átomos, e, por sua vez, provocará de modo semelhante a criação das espécies animais, como se de um ser racional se tratasse, o que a faz merecedora do nome de mãe. Esta bela paisagem que Lucrécio descreve no Livro V ilustra brilhantemente o nascimento da terra (5.783-796):

\author{
No princípio a espécie das ervas e o verde esplendor \\ foi a terra que o deu; ao redor dos cerrados e pelos campos todos, \\ floridos brilharam os prados, verdejantes de cor, \\ $e$ às diferentes árvores outorgou-se depois, pelos ares, \\ a magna contenda de crescer, soltas as rédeas. \\ Tal como plumas, pêlos e cerdas primeiro despontam \\ dos quadrúpedes, nos membros, e no corpo dos alados, \\ assim também, nova, a terra ervas e arbustos primeiro \\ fez brotar, e logo criou as espécies mortais, \\ muitas, de muitos modos e por várias causas nascidas. \\ Pois nem do céu ter caído podem os animais, \\ nem os seres terrestres ter saido das salobras profundidades. \\ Resta só que mereça receber o nome de mãe \\ a terra, pois foi a partir dela que todas as coisas foram criadas $^{13}$.
}

'Floridos brilharam os prados, verdejantes de cor': num só verso tudo fica dito, ou seja, fica expressa a paisagem natural que Lucrécio concebe como ideal, que desenvolve poeticamente, que admira e ama. Trata-se de uma paisagem suave, de que estão ausentes as grandes elevações e os grandes precipícios, conformada por planícies e elevações ligeiras; podemos comprová-lo repassando a utilização constante, ao longo dos seis livros do De rerum natura, do substantivo campus $^{14}$, ao lado do muito menos presente collis ${ }^{15}$, em alguns casos sugestivamente coordenados $^{16}$; essa topografia sem estridências converte-se numa paisagem bela sobretudo graças à cor, em que predomina como base o uiridis dos campos, semeados com muita frequência por multicoloridas flores. Pensemos por um

${ }^{13}$ Trad. de Maria de Fátima Silva.

${ }_{14}$ Lucr. $1.18 ; 1.273 ; 2.5 ; 2.40 ; 2.324 ; 2.330 ; 2.332 ; 2.660 ; 3.1002 ; 4.389 ; 4.459 ;$ 5.488; 5.492; 5.603; $5.784 ; 5.952 ; 5.1373 ; 5.1375 ; 6.267 ; 6.405 ; 6.712 ; 6.736 ; 6.1142$.

${ }^{15}$ Lucr. $1.999 ; 2.317 ; 2.322 ; 4.389 ; 4.578$ bis; $5.784 ; 5.1373$.

${ }_{16}$ Lucr. 4.389; 5.784; 5.1373. 
instante que o interesse de Lucrécio pelas cores se manifesta de maneira muito chamativa em toda a sua obra, não apenas porque, como filósofo, o preocupe o problema de explicar que os átomos têm $\operatorname{cor}^{17}$, mas porque o colorido que as coisas adquirem lhe parece uma qualidade importante, mesmo se secundária na sua constituição; este é um aspecto que fica bem patente no registo das cores ao longo de todo o poema ${ }^{18}$, através de reflexões tão surpreendentes como aquela que o poeta faz a propósito da mudança de cor das pombas e das caudas dos pavões reais, de acordo com a luz que neles incide ${ }^{19}$.

Quanto às flores, também a presença frequentíssima que têm ao longo de todo o poema é a prova mais óbvia da paixão que Lucrécio por elas nutre, que, neste caso, vai muito mais além de qualquer interesse de índole filosófica: uma reflexão sobre Lucrécio implica comprovar que, além do filósofo, nos deparamos com um homem, e, para além do homem, encontramos um enorme poeta. Flos, flores são substantivos de constante presença nos hexâmetros lucrecianos ${ }^{20}$, na maior parte dos casos no seu sentido próprio, mas por vezes também em sentido figurado do que a vida tem de melhor ${ }^{21}$; o próprio poeta nos confessa o prazer que sente em colher flores frescas, ... iunatque nouos decerpere flores num interessante passo do livro I (v. 928), que repete no princípio do livro IV (v. 3), dando lugar - como com outras repetições - a uma das questões mais debatidas, quer seja a propósito das incongruências ecdóticas no nosso texto de Lucrécio, quer sobre o hábito lucreciano de repetir determinadas construções, ou mesmo passos completos, repetição que talvez tivesse corrigido, em certos casos, se tivesse submetido o conjunto da sua obra a uma correcção prévia à sua ediçãa ${ }^{22}$. Simples ou dupla, aí está a confissão de Lucrécio sobre o seu amor às flores, que usa para criar a formosa imagem uiridantis floribus herbas, que também neste caso repete, num passo como complemento de conspergunt (2.33), e noutro de pingebant (5.1369). E, por falar de flores, lembremos o uso dos verbos florere e florescere, dos adjectivos florens, florifer, floridus, umas vezes para construir metáforas tão surpreendentes como a do cavalo brioso que floresce aos três anos de idade (5.884), ou a não menos bela do mar que, no tempo em que se

${ }^{17}$ Cf. Lucr. 2.730 ss.; a tradição cria em 2.755 um capítulo denominado COLORES NON EsSE, e em 2.842 outro que assinala específicamente ATOMOS NEC COLOREM NEC ODOREM NEC SVCVM NEC FRIGVS NEC CALOREM HABERE.

${ }_{18}$ Lucr. $1.767 ; 2.418 ; 2.501 ; 2.503 ; 2.679 ; 2.734 ; 2.736 ; 2.737 ; 2.743 ; 2.747 ; 2.749 ; 2.755$; $2.757 ; 2.759 ; 2.764 ; 2.775 ; 2.776 ; 2.783 ; 2.786 ; 2.789 ; 2.793 ; 2.795 ; 2.797 ; 2.798 ; 2.907 ; 2.811$; $2.813 ; 2.815 ; 2.818 ; 2.821 ; 2.823 ; 2.825 ; 2.828 ; 2.830 ; 2.832 ; 2.838 ; 2.842 ; 2.1005 ; 2.1030$; $3.267 ; 4.74 ; 4.80 ; 4.95 ; 4.167 ; 4.243 ; 4.266 ; 4.492 ; 4.493 ; 4.707 ; 4.1033 ; 4.1094 ; 5.750 ; 5.785$; $5.941 ; 5.1058 ; 6.205 ; 6.213 ; 6.526 ; 6.722 ; 6.812 ; 6.1109 ; 6.1112 ; 6.1188$.

${ }^{19}$ Cf. Lucr. 2.799-804.

${ }^{20}$ Lucr. $1.8 ; 1.564 ; 1.900 ; 1.928 ; 2.33 ; 2.628 ; 2.848 ; 3.221 ; 3.770 ; 4.3 ; 4.1134 ; 4.1178$; $5.671 ; 5.847 ; 5.1396 ; 5.1400 ; 6.787$;

${ }^{21}$ Cf. aeui florem Lucr. 1.564; aetatis florem 3.770; 5.847

${ }^{22} \mathrm{Cf}$., ainda as notas correspondentes nas edições comentadas de Munro, Giussani, Merrill, Bailey, Dionigi, bem como o comentário de Ernout y Robin, o estudo destes problemas em M. Bollack (1978), La raison de Lucrèce. Paris, p. 26 ss.; I. Dionigi (1988), Lucrezio. Le parole e le cose. Bologna. p. 105 ss.; etc. 
prepara para nascer a escrita e a poesia, floresce com os seus barcos à vela: tum mare ueliuolis florebat ${ }^{23}$.

Neste passo tão formoso, que nos levaria gostosamente a um comentário sem fim, é-nos dito, sem quebra, que a natureza dá rédea solta 'às árvores' para que disputem, entre elas, uma corrida até às alturas

\section{Algumas paisagens notáveis}

Na pormenorizada enumeração de figuras de estilo que apresenta a Rhetorica ad Herennium, livro IV, ao referir a que dá pelo nome de conmutatio, oferece, entre outros exemplos, este tão interessante, cuja paternidade se atribuía ao poeta Semónides: Poema loquens pictura, pictura tacitum poema debet esse $e^{24}$. Anos mais tarde, Horácio resumiria tão sábia reflexão no começo de um hexâmetro da sua Ars poetica, que o curso do tempo havia de converter num famoso topos literário: Vt pictura poesis ${ }^{25}$. Não sabemos se Lucrécio, profundo conhecedor das duas literaturas, conhecia a frase de Semónides ou o exemplo de conmutatio da Ad Herennium; pelo contrário, é certo que, ao longo do seu poema, nos oferece exemplos excelentes de paisagens, de cuidado e delicado tratamento poético, que, se os lemos, naturalmente em voz alta, resultam num poema, mas que podemos também imaginar, agora sem voz, como uma tela. $\mathrm{O}$ traço das figuras converte-se em substantivos, o seu colorido fica por conta dos adjectivos; a actuação sugerida compete aos verbos, e sobre a sua adequação ao conjunto opinam os advérbios; Lucrécio sabia, ou melhor, intuía, antecipava, que o mais importante era a selecção e o uso adequado dos quatro tipos de palavras plenas da linguística estrutural para conseguir um bom poema, e sem dúvida sabia da sua correspondência numa realização pictórica.

Vejamos um exemplo excepcional: Lucrécio empenha-se em explicar a Mémio e aos romanos que este seu distinto amigo representa, que as coisas que vemos são formadas por um número infinito de partículas invisíveis e indivisíveis, que, por contacto, originam os corpos, mas que seguem depois em movimento contínuo, que acabará por lhes originar a morte. Filosoficamente parece muito correcto, mas é diferente convencer o leitor atónito de que todos os objectos que vê ou toca são formados por um conjunto de corpos minúsculos, em dança interminável. Pois bem, Lucrécio reconhece que o facto de não percebermos o movimento das componentes dos corpos é perfeitamente explicável, devido a um defeito de percepção, que nos impede de os ver; mais ainda, que, por vezes, corpos que normalmente vemos podem parecer-nos imóveis pela mesma razão. E para dar dois exemplos incontestáveis do que pretende explicar, oferece-

${ }^{23}$ Lucr. 5.1442, verso lamentavelmente de leitura muito difícil nas suas duas últimas palavras; Bailey lê tum mare ueliuolis florebat + propter odores +, colocando inter cruces a leitura dos mss, $O Q$, que fazem pouco sentido, mas que não se atreve a emendar.

${ }^{24}$ Rhet. ad Her. 4.39: "Um poema deve ser uma pintura que fala, e uma pintura um poema

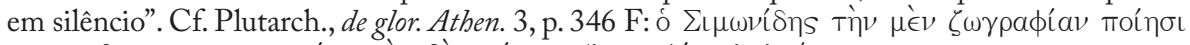

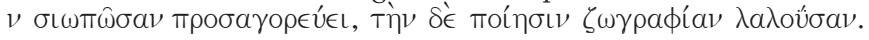

${ }^{25}$ Hor. Ars 361. 
nos dois magníficos quadros: no primeiro, umas ovelhas a pastar no cume de um monte; no segundo, uns ginetes que simulam um combate violento. Eis como o poeta transforma animais e homens, a sua situação e movimentos em substantivos, adjectivos, verbos e advérbios em duas belas paisagens, que nos parecem muito distintas se contempladas à distância (2.317-332):

\begin{abstract}
Pois por vezes numa colina, tosando os alegres pastos
serpenteiam felpudas ovelhas, até onde, chamando cada uma, as convidam as ervas perladas pelo recente rocio, e os cordeiros saciados brincam e com carinho se empurram, um conjunto que a nós, de longe, nos parece confuso e uma espécie de branco resplendor imóvel na verde colina. Além disso, quando grandes legióes em corrida enchem a vastidão dos campos, realizando simulacros de guerra, um resplendor ergue-se ao céu e em volta, toda de bronze, resplandece a terra; sob os passos de valentes varóes produzem-lhes os pés um ruido e pelo clamor os montes golpeados elevam as vozes até aos astros do mundo; revoluteiam em torno os ginetes e de repente atravessam pelo meio do campo, sacudindo-o com brioso impeto. Há, no entanto, um lugar no alto dos montes de onde parecem quietos, e haver, na planicie, um fulgor parado ${ }^{26}$.
\end{abstract}

Vt pictura poiesis: a paisagem das ovelhas no monte não pode exprimir-se de modo mais rápido nem mais formoso: o lugar é um monte baixo, collis, coberto de erva viçosa, ou seja, de verde, aspecto em que insiste primeiro a chamativa adjectivação pabula laeta, mas sobretudo quando nos é dito de forma muito poética que as ervas, cobertas de pérolas depositadas pelo rocio, chamam as ovelhas, convidam-nas, e elas respondem com movimentos coleantes Não se pode dizer melhor, não se pode pintar melhor. $\mathrm{E}$ - porque não - o amor profundo de Lucrécio pelos animais anima-o a acrescentar a nota emotiva dos cordeiros que, saciados, se entretêm a brincar, como crianças ${ }^{27}$. Todo o quadro, de formoso colorido e de movimento animado, converte-se numa mancha branca brilhante, deposta sobre um verde altaneiro. Algo de muito semelhante se passa quando, do alto de uma colina, dirigimos o olhar para os soldados que, ao longe, se exercitam em marcha e a cavalo; o brilho que desprendem, na convulsão do seu vaivém, converte-se para nós num resplendor parado, graças à distância que nos separa.

${ }^{26}$ Trad. de Maria de Fátima Silva.

${ }^{27}$ Cf. o comentário que fiz sobre este mesmo passo em "Otra lectura de Lucrecio: su pasión por los animales”. conferência apresentada no V Congresso Andaluz de Estudos Clássicos, Cádis, 2006, no prelo. 
6. Paisagens reais de interesse

Não é frequente em Lucrécio a descrição de paisagens reais, embora encontremos algumas no De rerum natura, que o poeta refere sobretudo naqueles casos que detêm alguma característica particular, a exigir uma explicação adequada com base nos pressupostos da física atómica que nos propõe. Com frequência, Lucrécio desconhece paisagens distantes que the despertam curiosidade graças a estranhas características: tal é o caso da fonte próxima do templo do deus egípcio Ámon, no oásis da Cirenaica, cujas águas são frias de dia e quentes de noite ${ }^{28}$, ou a fonte ardente que existe no santuário de Dodona, no Epiro, que é fria, mas incendiária ${ }^{29}$, ou a fonte de Arados, na Fenícia, que emana água doce apesar de se encontrar no interior do mar... ${ }^{30}$ A natureza dispõe de lugares onde ocorrem fenómenos que precisam de uma explicação racional, dado que são contrários à nossa experiência normal: o vulcão do Etna, com a evocação das suas erupções aterradoras ${ }^{31}$, ou o estranho comportamento do Nilo, o único rio que, ao contrário de todos os demais, cresce e inunda os campos durante o verão ${ }^{32}$; são, por assim dizer, paisagens que se tornam, sem dúvida, surpreendentes e que têm de entender-se sem recorrer a explicações sobrenaturais; razões porque Lucrécio se detém na sua descrição e consideração.

No entanto, não responde a nenhuma necessidade de consideração filosófica o famoso excurso sobre a ilha da Sicília, tratada com afecto e entusiasmo evidentes por Lucrécio, que a faz reluzir no livro I sem outro fim que não seja o de prestar homenagem a um dos seus filhos mais ilustres, Empédocles de Agrigento, precisamente no início de um passo em que lhe vai considerar as teorias $(1.716-730)^{33}$ :

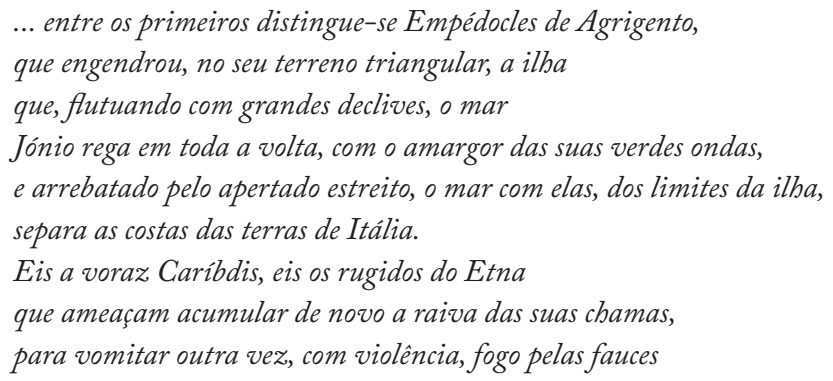

${ }^{28}$ Lucr. 6.846 ss.

${ }^{29}$ Lucr. 6.879 ss.

${ }^{30}$ Lucr. 6.890 ss.

${ }^{31}$ Lucr. 6.639 ss.

${ }^{32}$ Lucr. 6.712.

${ }^{33}$ É, aliás, bem conhecida a estreita relação de Lucrécio com a filosofía de Empédocles, sobre a qual se pode consultar D. Sedley (1998), Lucretius and the Transformation of Greek Wisdom, Cambridge, esp. 1-34 (reproduzidas, com o título "The Empedoclean Opening”, em M. R. Gale (ed.) (2007), Lucretius: Oxford Readings in Classical Studies. Oxford, 48-87. 
e lançar ao céu de novo os fulgores da sua chama.

E embora esta grande região pareça em muitos aspectos admirável

ao género humano e se diga digna de ser visitada,

opulenta em bens, dotada de homens valorosos,

parece todavia não ter tido nenhum outro mais ilustre do que este varão,

ou mais sagrado, mais admirável ou precioso ${ }^{34}$.

É sabido que os romanos sentiam viva admiração ou, melhor ainda, carinho, pela Sicília, a sua primeira possessão extra-peninsular e a sua primeira província. Todos os romanos ilustrados, e entre eles o nosso Lucrécio, tinham uma consciência clara do quanto a cultura romana devia à influência grega, chegada através das cidades importantes da Sicília, desde há séculos, elas mesmo berço de grandes escritores e pensadores como os poetas Estesícoro e Teócrito, o orador Górgias, os filósofos Empédocles e Arquimedes, o historiador Timeu, etc. Quando Lucrécio escreve os versos que acabo de recordar, sem dúvida que se mantinha viva em Roma a imagem de Cícero, a defender com brio, no ano de 70 a. C., os Sicilianos, contra a corrupção do governador Verres, num processo que daria lugar à publicação das Verrinas, obra fundamental na produção oratória de Cícero e um canto de elogio da Sicília, das suas gentes, das suas belezas, dos seus bens culturais Não parece demasiado arriscado pensar que Lucrécio tivesse tudo isto presente quando, no v. 726, apresenta a ilha como uma região magna modis multis miranda na opinião geral, expressão aliterante que se poderia empregar com toda a propriedade como magnífico reclame turístico, e, precisamente por isso, se considera a seguir que há que visitar a ilha. Muitas são as coisas boas da Sicília, na opinião de Lucrécio, os seus bens e os seus homens; mas, seguindo com o inventário dos atractivos da ilha, o filósofo assinala que nada houve nela mais glorioso, mais sagrado, mais admirável nem mais precioso do que o seu filho Empédocles de Agrigento. Uma vez mais, em Lucrécio, uma paisagem formosa serve de marco adequado para apresentar um homem formoso.

\section{A paisagem amada por Lucrécio}

Na linha da tendência inaugurada por Gneu Névio, no seu Bellum Poenicum, de introduzir o poeta no poema épico, não só como artífice, mas como mais uma personagem interveniente nas façanhas narradas ${ }^{35}$, tendência logo continuada por Quinto Énio, que, sem recato, se apresentava abertamente no começo dos seus Annales como continuador latino de Homero ${ }^{36}$, Lucrécio surpreende-nos

${ }^{34}$ Trad. de Maria de Fátima Silva.

${ }^{35}$ Cf. Gell. 17.21,44-45: Anno deinde post Romam conditam quingentesimo undeuicesimo Sp. Caruilius Ruga primus Romae de amicorum sententia diuortium cum uxore fecit [...], eodemque anno Cn. Naeuius poeta fabulas apud populum dedit, quem $M$. Varro in libro de poetis primo stipendia fecisse ait bello Poenico primo idque ipsum Naeuium dicere in eo carmine quod de eodem bello scripsit.

${ }^{36}$ Cf. G. P. Pighi (1926), Il proemio degli Annali di O. Ennio. Milano; J. H. Waszink (1950), "The Proem of the Annales of Ennius", Mnemosyne s. 4,3 215-240; R. Reggiani (1979), I proemi degli An- 
a cada passo, ao longo do seu De rerum natura, irrompendo sem problema para expressar o seu modo pessoal de se posicionar em relação ao tema que trata. Eis a razão pela qual, quando lemos, com atenção, o nosso poeta, a sua personalidade se nos torna tão próxima, tão conhecida, e, em consequência, tão admirável e tão amiga, ou, para dizê-lo numa só palavra, tão nossa. O mesmo aconteceria se considerássemos o conjunto de múltiplos passos em que Lucrécio nos descreve paisagens, com o objectivo de saber qual era a paisagem que mais amava, a sua preferida, o seu locus amoenus por excelência. No entanto, essa reflexão torna-se desnecessária, porque há dois momentos no poema em que o nosso autor nos tira qualquer dúvida sobre a matéria, em 1, 926-930 e em 2, 29-33, dando-se a coincidência curiosa de que ambos voltam a aparecer uma vez mais, segundo já antes assinalei, numa formulação, idêntica no primeiro caso, e com ligeiras variantes no segundo, em 4,1-5 e em 5, 1391-1396.

No primeiro destes dois passos, Lucrécio manifesta-nos o orgulho que sente pela composição da sua obra poética, que compara a um ameno passeio por uma paisagem bela, nunca antes percorrida por outros pés, em cujas fontes bebe e de cujo campo colhe flores para tecer uma coroa. É fácil darmo-nos conta de que nos encontramos perante uma paisagem campestre, florida, aprazível, que noutros lugares vemos tratada com grande elevação poética por Lucrécio (1.926-930, cf. 4.1-5):

\author{
percorro os lugares distantes das Piérides por nenhum pé \\ antes pisados. Agrada-me alcançar as fontes intactas \\ e beber delas, agrada-me colher flores novas \\ e buscar ali, para pôr na cabeça, uma ilustre grinalda, \\ com que nunca antes as Musas, a ninguém, cingiram a fronte ${ }^{37}$.
}

No segundo passo, Lucrécio coloca num lugar idílico, natural, sem artifícios nem luxos palacianos, um grupo de amigos, sem dúvida de acordo com os preceitos do jardim. Muda apenas o lugar: é um espaço natural, um campo florido, nas margens de um rio, sob a ramaria de uma árvore corpulenta (2.2933):

... quando porém entre si estendidos em prado suave

junto a um riacho, sob os ramos de uma árvore elevada,

sem grande esforço, com prazer, de seus corpos cuidam,

sobretudo quando o tempo sorri e a estação

do ano tinge de flores as ervas verdejantes ${ }^{38}$.

nali di Ennio: programma letterario e polemica. Roma; A. Pociña (1989), "Herencia griega y aportación romana en la épica de la República”, en Actas del VII Congreso Español de Estudios Clásicos. Madrid, 383-404.

${ }^{37}$ Trad. de Maria de Fátima Silva.

${ }^{38}$ Trad. de Maria de Fátima Silva. 
Com leves e discretas mudanças voltam a aparecer estes versos em 5, 1391-1396, aí não para referir-se a um lugar de repouso e contemplação do sábio epicúrio, mas como ambiente em que supõe que os homens, de épocas primitivas, reunidos em plácido repouso e camaradagem, propiciaram a invenção da música.

Não vou tirar conclusões desta abordagem rápida da utilização da paisagem por Lucrécio. Volto, isso sim, ao começo da minha exposição, onde recordava a advertência de Michael von Albrecht de que 'este é o momento de redescobrir, em Lucrécio, o poeta', e acrescento que é também o momento para voltar a lê-lo, em busca do grande defensor da natureza, do grande enamorado da natureza, num mundo como o nosso que faz tudo o que pode para destrui-la.

[Desejaria que constasse o meu imenso agradecimento à doutora Maria de Fátima Silva, professora Catedrática da Universidade de Coimbra, pela ajuda que me prestou ao redigir a versão portuguesa deste trabalho, e de forma assinalada pelas suas formosas traduções dos versos de Lucrécio] 
(Página deixada propositadamente em branco) 


\title{
O MITO DE ORPHEUS. A PLASTICIDADE DO MITO NAS VOZES DE VIRGÍLIO, VINÍCIUS E CAMUS
}

\author{
Elaine C. Prado dos Santos \\ Universidade Presbiteriana Mackenzie
}

\begin{abstract}
The myth of Orpheus was explored and retaken in almost all forms of artistic manifestations. The mythic creation, properly understood, consists in giving new senses to ancient myths. The present study proposes not only the presentation of the myth of Orpheus in the Georgics, by Vergilius, in a comparative line with the play Orfeu da Conceição, by Vinícius and with the movie Orfeu Negro (1958), by Camus; based on the theoretical subsidies of parody formulated by Hutcheon, but also the verification, in such analysis, of how the dialogic relations between different universes is established.
\end{abstract}

Keywords: Georgics, myth of Orpheus, Orfeu da Conceição, Orfeu Negro, Vergil.

Palavras-chave: Geórgicas, mito de Orfeu, Orfeu da Conceição, Orfeu Negro, Virgílio.

Um dos mitos que excedeu as fronteiras do tempo, simbolizando a celebração da imortalidade da poesia, é o de Orfeu, cuja transposição para quase todas as formas de manifestações artísticas comprova sua atemporalidade. De Virgílio a Vinícius e a Camus, o mito de Orfeu demonstra plasticidade, ao se revestir de formas mais modernas e diversificadas.

A partir dos conceitos da paródia formulados por Hutcheon, a proposta deste trabalho visa não só a apresentar o mito de Orfeu, nas Geórgicas de Virgílio (I a.C.), em uma linha comparativa com a peça Orfeu da Conceição (1956) de Vinícius de Moraes e com o filme Orfeu Negro (1958) de Marcel Camus, mas também verificar como se estabelecem as relações dialógicas entre esses universos e demonstrar que o mito é recriador.

Muitos teóricos da paródia remontam a raiz etimológica do termo ao substantivo grego parodia, que quer dizer "contra canto". Conforme Hutcheon 1985: 47, a natureza textual ou discursiva da paródia é evidente no elemento odos, que significa canto. $\mathrm{O}$ prefixo para tem dois significados, mas geralmente apenas um é mencionado, o de delinear. A paródia é uma repetição que inclui diferença, uma imitação com distância crítica. Sob essa perspectiva, pretendese verificar como se estabelece a paródia nos universos: Orfeu da Conceição e Orfeu Negro a partir do poema das Geórgicas de Virgílio, que será apreciado por esta comunicadora como texto fonte.

O poeta latino, Publius Vergilius Maro, no IV canto das Geórgicas, poema didático sobre a terra, apresenta a apicultura em um quadro agrícola, ilustrando 
o mito de Orfeu, a fim de retratar a verdade eterna do mito que se pode reencontrar na natureza.

Vinícius, inspirado na tradição clássica, escreveu a peça Orfeu da Conceição, que é uma modernização do mito grego ao ambiente de uma favela carioca. A tradição lendária estabelece a dupla ligação de Orfeu com Apolo, deus do Sol e com Dioniso, deus do vinho. Em sua versão, Vinícius deu ênfase às relações entre essas duas instâncias - apolínea e dionisíaca - no quadro específico da cultura brasileira.

No filme Orfeu Negro, o mito é transposto para o universo da favela da Babilônia, no Rio de Janeiro. Por meio desse deslocamento, Camus dessacraliza o mito, em uma aproximação ao mundo da favela, instaurando uma nova leitura, pois tudo o que é ideal e sublime é transferido para o plano material.

Vinícius e Camus utilizam acréscimos ao mito que estão presentes na cultura brasileira: favela, carnaval e samba, empregando, nessa recriação mítica, a paródia não só para enaltecer as particularidades oriundas do Brasil, mas também para criticar socialmente valores que o ser humano deixou para segundo plano.

No mito, Orfeu, possivelmente de origem trácia, era filho da musa Calíope e do rio Eagro, que, freqüentemente, é substituído por Apolo. Nas Geórgicas, o apicultor Aristeu tentou violentar Eurídice, que, em sua fuga, morreu picada por uma serpente. E como castigo, Aristeu perdeu suas abelhas. O músico e cantor, Orfeu, desesperado, desceu aos Infernos para trazer a esposa de volta. Com sua divina voz, encantou o mundo ctônico, pois a lira comoveu Caronte, que largou o barco e seguiu o cantor; Cérbero emudeceu suas três goelas abertas (Geo. IV, 471-484); os tormentos eternos ficaram, por um instante, imobilizados diante da maravilhosa voz de Orfeu (Geo. IV, 481-484).

Comovidos com a voz de Orfeu, os deuses, Plutão e Prosérpina, concordaram em devolver-lhe a esposa, entretanto uma condição foi imposta: ele iria à frente e ela lhe acompanharia os passos. Orfeu não poderia olhar para trás, mas não resistiu, ao olhar, perdeu Eurídice. Inconsolável, passou a repelir todas as mulheres da Trácia, as Mênades, que se sentiram desprezadas por tal fidelidade à esposa, mataram-no e esquartejaram-no e lançaram-lhe os restos e a cabeça no rio Hebro. Ao rolar a cabeça no rio, sua boca proferiu o nome de Eurídice (Geo. IV, 526-527).

O episódio da descida de Orfeu ao mundo dos mortos revela, em um sentido clássico, uma reflexão sobre a morte e a continuidade da tradição multissecular, que atribuía à música e ao canto poderes mágicos que transcendiam a vontade dos próprios deuses.

Nas Geórgicas, Orfeu e as abelhas estão ligados pela simbologia de sobrevivência após a morte. Os antigos pensavam que elas nasciam espontaneamente das entranhas dos touros imolados em honra dos deuses (Geo. IV, 281-285) de tal forma que Virgílio declara genus immortale manet (Geo.IV, 208).

Vinícius não apresenta a sociedade das abelhas; no entanto, apresenta Aristeu como um apicultor e relata o canto poético de Orfeu carregado de 
mel. No filme, não há qualquer referência às abelhas, ao mel e à personagem Aristeu.

$\mathrm{Na}$ peça, o mulato Orfeu mora em um barraco, não toca lira, mas toca divinamente violão, cujo som será apresentado como um contraste a barulhos desordenados, associados à ameaça do caos. Em sua apresentação, Orfeu surge brilhante no meio da noite, referência à sua natureza apolínea. Segundo observações de Vinícius, as festas e os rituais dos negros pareciam muito com os rituais gregos, marcados pelo lado dionisíaco da vida. Vinícius demonstra os traços da cultura popular que deveriam ser reelaborados com a música de Orfeu. Assim o grego da Trácia virou o negro da favela, que amava a mulata mais bonita do morro, Eurídice. Por inveja, Aristeu matou, com um punhal, Eurídice, o lado sublime de Orfeu.

No filme, o mulato Orfeu é um motorneiro de bonde, um jovem talentoso compositor, que mora na favela da Babilônia e que está se preparando para o Carnaval. Na desconstrução, por meio da paródia, Vinícius e Camus carnavalizam o mito, não como uma negação ao que está sendo parodiado, mas como objeto de reconstrução. Para Hucheon 1985:146, a paródia é hoje dotada do poder de revitalizar. Camus realiza um painel folclorizado da vida do morro carioca, o filme focaliza unicamente a comunidade negra e favelada, em uma primeira seqüência de Carnaval, em poucos momentos aludindo a outras facetas da vida local, sugerindo um contraste entre a modernidade e o ambiente anárquico do morro.

Em Camus, Eurídice é perseguida pela Morte, um homem fantasiado, lembrando a figura de Arlequim. Em sua fuga, assustada, Eurídice morre eletrocutada por um dos fios de alta tensão de uma estação de trem. Tanto na peça quanto no filme, Eurídice é associada a um princípio de organização da existência individual e do cosmos - que, aliás, reflete o que o próprio Orfeu representa para a comunidade. Esse traço se mantém e é reforçado na versão cinematográfica: sua inocência contrasta com as mulheres do morro. As implicações do sentido ritual do Carnaval não se perdem de vista em vários detalhes no desenvolvimento da narrativa fílmica que procura acentuar o dionisismo que Vinícius dizia ter descoberto na cultura negra.

Nas Geórgicas, ele canta e toca sua lira envolvendo todos com o poder mágico de sua voz. Em Orfeu da Conceição, ele sempre traz o violão a tira colo. Tudo aprendera com seu mestre, o pai Apolo, que na mitologia, é o deus do Sol e da inspiração poética. Em Orfeu da Conceição, Apolo é aquele que só sabe beber no botequim.

No filme, Orfeu também toca violão, encantando a todos os moradores e a todas as mulheres, com a sua música. Ao desfilar no Carnaval, Orfeu dança representando o Sol, uma alusão ao deus Apolo. As crianças acreditam que Orfeu consegue, com sua voz e com seu violão, fazer o Sol se levantar todas as manhãs.

Em Vinícius, Orfeu entra, com o seu canto poético, no inferno, retratado como o Clube dos Maiorais. Todos dançam e cantam; no entanto, quando o som cristalino do violão de Orfeu corre escalas dulcíssimas, todas as figuras 
presentes se imobilizam diante dele. Com sua voz, as mulheres repetem o nome da amada. Os deuses ctônicos, em Vinícius, são invertidos para os mais comuns dos mortais: Plutão, o inflexível presidente dos Maiorais do Inferno e Prosérpina, a rainha bêbada.

Orfeu, ao saber da morte de Eurídice, no filme, a procura por toda parte. Ao chegar ao local dos desaparecidos, no décimo segundo andar de um edifício, encontra um vasto corredor com muitos papéis espalhados pelo chão e um faxineiro que varre toda aquela papelada. $\mathrm{O}$ décimo segundo andar é uma sugestão aos doze deuses do Olimpo, provavelmente abandonados a um arquivo morto. $\mathrm{O}$ faxineiro, como o mítico barqueiro Caronte, conduz Orfeu ao Inferno. Desenha-se a catábase, segundo o cineasta, quando Orfeu desce os inúmeros degraus de uma sinuosa escadaria.

Nas Geórgicas, Cérbero, o cão dos infernos, emudece diante da voz maravilhosa de Orfeu. $\mathrm{Na}$ peça, no Clube do Inferno, Cérbero, o leão-dechácara, recua dominado pelo toque da música de Orfeu. No filme, Cérbero, um cão que fica na entrada de uma casa de Candomblé, permite a passagem de Orfeu.

O inferno de Camus é retratado como uma casa de Candomblé, iluminada por um tom avermelhado, onde acontece um ritual religioso, no qual não se ouvem os sons harmoniosos da cítara, mas homens e mulheres dançam, invocando as entidades. Projeta-se, na cena, uma velha, que, com a voz de Eurídice, pede a Orfeu que não olhe para trás, mas ele mais uma vez não resiste.

Vinícius substituiu o Hades pelo clube dos Maiorais e Camus por uma casa de Candomblé, para atualizar, por meio do mito, esse tipo de cultura. O canto, por sua eficácia, consegue, por uma vez vencer a morte. A perda da amada aconteceu não pela impotência do canto e sim pela dementia causada pelo amor (Geo. IV, 488). Nas Geórgicas, Orfeu foi imprudente, olhou para trás e perdeu Eurídice (Geo. IV, 491-492). Em Orfeu da Conceição, o músico se afasta de costas em direção à porta de saída. Em Orfeu Negro, uma senhora pede que Orfeu não olhe para trás.

Conforme Brandão 1991: 143, Orfeu poderia ter trazido Eurídice de volta, se não tivesse olhado para trás, pois ao olhar para trás, transgride as direções. Partiu-se a harmonia, só reconquistada se houver um retorno perfeito.

Virgílio exprime sua piedade por Orfeu, quando perde Eurídice, abrindo-se um cenário de breves interrogações (Geo. IV, 494-495). Em Vinícius, o coro se apieda de Orfeu. Em Orfeu Negro, há o acréscimo de Hermes, o vigia da estação e amigo de Orfeu, que o consola, indicando o caminho para o necrotério.

Nas Geórgicas, Eurídice é levada por uma imensa noite (Geo. IV, 498). Na peça, ela é levada pela gigantesca Dama Negra. No filme, ela é perseguida pelo Arlequim durante a noite de carnaval. A figura arlequinal, já ambígua e efêmera, é projetada, no filme, com um lado muito sombrio, por representar a imagem da morte que mata Eurídice, a sublime alma de Orfeu. Tanto a 
Dama Negra quanto Arlequim, somados ao mito, têm a função de representar a morte e conduzir Eurídice ao inferno.

Impotente para lutar contra a morte, tanto nas Geórgicas quanto na peça e no filme, ao sair dos infernos sem Eurídice, Orfeu prefere a solidão. Nas Geórgicas (Geo. IV, 507-510), Orfeu, no bosque, canta para os animais e em Orfeu da Conceição ele anda, na mata, como alma penada. Vinícius registra a desarmonia com a morte de Eurídice: sem Orfeu, no morro, não há mais violão. No filme, ele carrega o corpo de Eurídice em seus braços, subindo o morro carioca. Durante todo percurso, com uma música, agradece o amor à amada, enquanto um caminhão lava a rua, como um rito de purificação. Para Chevalier 1994: 15-18, as águas precedem a criação, é evidente que elas continuem presentes para a recriação. Ao Orfeu novo, que sobe o morro com Eurídice nos braços, corresponde a aparição de outro mundo renovado.

Segundo Brandão 1997: 114, a descida aos infernos configura o supremo rito iniciático: a catábase, a morte simbólica, é a condição para uma anábase, uma escalada definitiva na busca da anagnórisis, do autoconhecimento, da transformação do que resta do homem velho no homem novo. No filme, registram-se estes três momentos: a descida de Orfeu para resgatar Eurídice, sua morte simbólica, pegá-la em seu colo, e fazer sua anábase, subir o morro e buscar a anagnórisis: a lapidação e a harmonia de seu lado apolíneo.

Em Vinícius, as mulheres bêbadas, guiadas por Mira, em orgia, atiramse sobre Orfeu, com facas e navalhas. Como um Laocoonte, ao receber um castigo divino, Orfeu luta para desvencilhar-se da pena humana. As mulheres, na peça, não jogam a cabeça de Orfeu no rio; no entanto, Mira arremessa seu violão, atirando-o longe. Ouve-se o bater do instrumento e depois a música de Orfeu se afirma límpida. No filme, as mulheres, em um ritual de loucura, incendeiam alguns barracos. Ao ver Orfeu com Eurídice nos braços, Mira, em um ato de fúria, atira-lhe uma pedra, matando o cantor Orfeu.

Nas Geórgicas, Aristeu cumpre ritos expiatórios e a vida renasce para suas abelhas (Geo. IV, 557-558). Em Orfeu da Conceição, Vinícius acrescenta ao mito um grupo de meninos engraxates que batem em suas caixas, tocando músicas de Orfeu, exemplificando a continuidade da vida. Em Orfeu Negro, está implícita a idéia do renascer. Após a morte de Orfeu, os meninos pegam o violão para fazer o Sol se levantar. Diante deles, o Sol ressurge e uma das crianças faz o seguinte comentário: "você fez o Sol se levantar, agora você é Orfeu”. Para Eliade 1991:77, a noite da qual nasce o sol todas as manhãs simboliza o caos primordial, e o nascer do sol é uma réplica da cosmogonia.

Em Vinícius, o cantor é sempre apresentado todo de branco, cantando, sob a luz do luar. Conforme Chevalier 1994: 141, o branco é uma cor privilegiada dos ritos de iniciação: morte e renascimento. Já o vermelho é a cor do sangue. É interessante a apresentação da Dama Negra: gigantesca negra velha, envolta até os pés em um manto branco, trazendo um ramo de 
rosas vermelhas. No filme, Mira, noiva de Orfeu, aparece muitas vezes com uma rosa vermelha entre os seios.

Nos ritos de iniciação, o branco é a cor da primeira fase, a luta contra a morte, mas pode ser visto como a cor do leite materno. Luz da prata e da lua, em sua ronda completa, o leite é o arquétipo da mulher fecunda. Na peça, Orfeu olha para a lua e diz: "O mundo é todo leite/ Leite da lua, e a lua és tu, Eurídice".

Tanto Vinícius quanto Camus, em uma nova linguagem, reatualizam o mito nas condições históricas da sociedade brasileira, mostrando a existência de mitos nos tempos modernos, que são transformados e humanizados.

Virgílio, ao escrever sobre a apicultura, uniu as abelhas ao mito de Orfeu. A abelha é símbolo da ressurreição; o mel da força vital e da imortalidade. Os gregos representaram a abelha por Melissa, que figuradamente significa poeta. Orfeu, por meio do poder de seu canto, vence a própria morte. Se, numa segunda vez, perde Eurídice para sempre, é pela Dementia, pela paixão avassaladora que está dentro do ser humano. Entretanto, as abelhas renascem da própria morte, do sangue putrefato de um boi (Geo. IV., 208). Em Orfeu da Conceição, os meninos cantam as músicas de Orfeu. $\mathrm{O}$ violão mesmo despedaçado retrata sua música límpida.

....Eurydicen nox ipsa et frigida lingua

Ah! Miseram Eurydicen anima fugiente nocabat;

Eurydicen toto referebant flumine ripae ${ }^{1}$. (Geo. IV, 525-527)

Segundo Vinícius, "Só não morre no mundo a voz de Orfeu”, a voz do poeta continuará clamando pela eternidade e fará o Sol se levantar todos os dias com a música, com a poesia e com o amor.

\section{Bibliografia}

J. de Souza Brandão (1991), Mitologia grega. 4a ed. Petópolis: Vozes, v. 2. (1997), Mitologia grega. 7a ed. Petópolis: Vozes, v. 3.

Jean Chevalier; Alain Gheerbrant (1994), Dicionário de simbolos. Coord.

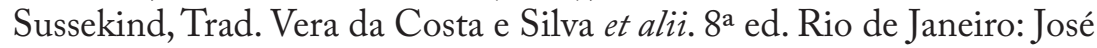
Olympio.

Mircea Eliade (1991), Mito e realidade. Trad. Póla Civelli. 3a. ed. São Paulo: Perspectiva.

(2001), O sagrado e o profano, Trad. Rogério Fernandes. 5a . ed. São Paulo: Martins Fontes.

Linda Hutcheon (1985), Uma teoria da paródia. Ensinamento das formas de arte do século XX. Lisboa: Edições 70.

\footnotetext{
${ }^{1}$ A própria voz e a lingua fria, enquanto a alma fugia, chamava Eurídice, ab! Triste Eurídice! As margens ecoavam Eurídice, ao longo de todo rio.
} 


\title{
ESPAÇO E PAISAGEM EM DOZE NAUS \\ DE MANUEL ALEGRE
}

\author{
José Ribeiro Ferreira \\ Universidade de Coimbra \\ Centro de Estudos Clássicos e Humanisticos
}

\begin{abstract}
Resumo
O trabalho procura analisar o espaço e a paisagem no último livro de poemas de Manuel Alegre, Doze Naus, em especial os espaços e paisagens greco-romanos. São muitas as composições que têm um espaço ou paisagem subjacente. Sobretudo nota-se grande insatisfação e uma busca constante de um lugar, da Ítaca ideal que nunca é o sítio em que se está ou chega. Relembro, a título de exemplo, o poema "Mar absoluto" em que as naus de Ulisses partem, «navios a sair do cais / para outro espaço outro crepúsculo outra aurora». E todas falham, com excepção de uma que chega ao seu destino, entra pela poesia dentro e o poeta é esse navegar, é «o que procura mesmo se ninguém responde», é «o que pergunta pelo mar». Outro exemplo elucidativo é o poema "A curva", que é o ponto ou sítio onde «alguém tem de aparecer», porque a «vida toda» é «sonho a esperar sempre / naquela curva não importa quem».
\end{abstract}

A cultura clássica é rio que corre há mais de dois mil anos sem cessar, nunca o mesmo e nunca igual. Aluviões constantes, transmitidos ao longo dos tempos, adubam os produtos e criações da mente humana, sempre novos, sempre outros. E o baú da memória da humanidade recolhe os estratos sucessivos que aí ficam depositados e aí permanecem pujantes e vivos, sempre prontos a ser desfiados à mínima alusão ou associação.

O livro de poemas Doze Naus de Manuel Alegre é mais uma expressão desse rio que não pára de fluir. E nele as paisagens de Tróia, de Ítaca, de Lisboa, do Tejo, de Portugal aparecem como espaço ou teatro da vida de Ulisses, do poeta, do povo português. E todos eles se intercruzam, se identificam, como paisagens, espaços e símbolos de Portugal e do temperamento português.

Em Doze Naus o mito de Ulisses permanece essencial. E, ao longo do livro, o poeta continua a sua busca insatisfeita. São inclusive tópicos insistentes em especial nos poemas iniciais e nos finais - o mar, o barco, o rio, o vento. $\mathrm{O}$ próprio título do livro tem subjacente o número de barcos comandados pelo herói homérico na expedição contra Tróia, como vem referido no Canto 2 da 
Ilíada, no célebre episódio do "Catálogo das naus" (vv. 631-637). Traduzo os versos em causa:

Por sua vez Ulisses comandava os magnânimos Cefalénios,
que habitavam Itaca e o Nériton de folhas agitadas pelo vento,
e administravam Crocileia e a áspera Egílipe;
os que detinham Zacinto e habitavam Samos,
os que possuiam o continente e habitavam a orla maritima.
Era seu comandante Ulisses, igual de Zeus no na prudência.
E com ele seguiam doze naus de cascos vermelhos.

De Tróia essas mesmas doze naus partiram com o herói de regresso a Ítaca (Odisseia 9. 159), embora a maioria delas sofresse a destruição (Odisseia 10127-132).

E esse número doze de naus aparecerá em vários poemas desta colectânea de Manuel Alegre. Em "Mar absoluto" (p. 19) - poema que parece repercutir "Mar português" de Fernando Pessoa e que abordarei adiante com mais pormenor - o sujeito vê «as doze naus de Ulisses ou talvez / a vida toda nesse breve instante / em que disseste mar pela primeira vez», as «doze proas pintadas de vermelho» (p. 20). O número de naus e a sua cor voltam a ser especificados no poema seguinte, intitulado precisamente "Doze naus pintadas de vermelho" (p. 22). Nele o poeta - identificado com Ulisses e com o povo português, como é usual no autor de Senhora das Tempestades - confia embarcar «nas doze naus pintadas de vermelho» que estão fundeadas, "paradas em frente da cidade de Príamo». Agora, porém, Ulisses está ferido e sentado, a pensar nas palavras que dirigiu ao guerreiro inimigo Soco, «sobre a morte e o obscuro destino», enquanto espera que chegue o médico

que lhe corre da coxa para o meio da página
junto das doze naus pintadas de vermelho.

O poema tem subjacente o passo do Canto 11 da Ilíada (vv. 426-488) em que Ulisses é atingido por Soco para vingar a morte do irmão Cárops, rasgando-lhe o flanco com a lança (v. 437) de onde o sangue jorra (v. 458). O Cefalénio, apesar de ferido, mata então Soco e dirige-lhe palavras duras, onde aparece referência expressa à morte e ao negro destino (v. 443: phonon kai kêran mélainan) que o espera, tópico também presente no poema de Manuel Alegre. Cito os versos em tradução de Frederico Lourenço (vv. 441-455):

\footnotetext{
"Desgraçado!' Agora veio ao teu encontro a morte escarpada!

Decerto me impediste de guerrear contra os Troianos;

mas a ti declaro eu que a morte e o escuro destino

te virão neste dia: pela minha lança subjugado,
} 
trar-me-ás a glória; ao Hades de nobres poldros, a tua alma."

Falou; e o outro recuou e lançou-se na fuga.

Enquanto se voltava, nas costas entre os ombros lhe fixou

Ulisses a lança, que lhe trespassou o peito.

Tombou com um estrondo e sobre ele exultou o divino Ulisses:

"Ó Soco, filho do fogoso Hipaso, domador de cavalos!

Rápido te sobreveio o termo da morte; não lhe escapaste.

Desgraçado! Teu pai e tua excelsa mãe não te fecharão

os olhos na morte, mas as aves de rapina que devoram

carne crua te dilacerarão, batendo todas cerradas as asas

à tua volta. Por mim, se morrer, sepultar-me-ão os Argivos."

Mas a intertextualidade do Canto 11 da Ilíada no poema "Doze naus pintadas de vermelho" é mais densa do que a simples referência a Soco e ao ferimento de Ulisses. Nesse teatro de guerra sem quartel que o Canto 11 do poema homérico descreve, os ferimentos dos combatentes aqueus são constantes (Agamémnon, Diomedes, Ulisses, Eurípilo). Quem os consola e os socorre com o apoio do médico Macáon é Nestor, o ancião Nestor de Gerénia. $\mathrm{E}$ a esse pormenor alude o poema de Manuel Alegre, ao especificar que Ulisses pensa nas palavras ditas a Soco,

à espera que Nestor de Gerénia o Velho

traga o médico (talvez Mácoon) para estancar o sangue

Vejamos o poema na íntegra, que é dedicado a Teresa Rita Lopes:

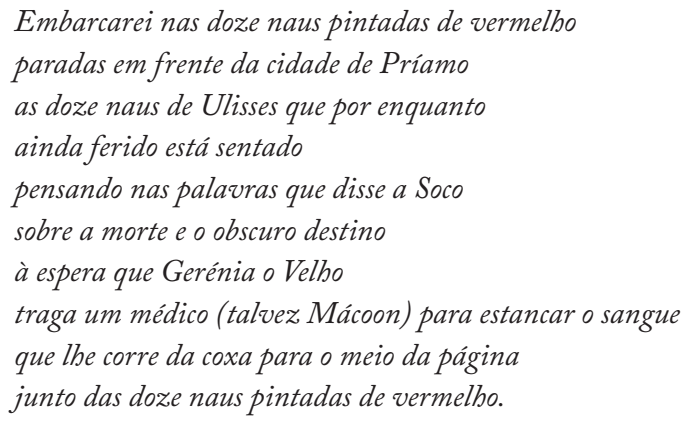

O final do poema dá um contexto e estabelece um espaço de ficção. $\mathrm{O}$ sangue que mana da coxa de Ulisses corre afinal para o meio da página, colocado portanto no domínio da criação poética.

Em 2001, publiquei pequeno opúsculo sobre os temas clássicos na poesia desse poeta, a que dei o título de Manuel Alegre: Ulisses ou os caminhos de eterna busca, em que mostrava ser o mito do filho de Laertes central, talvez mesmo o mais importante na obra do autor de O Canto e as Armas: Ulisses - que castiga 
a insolência e injustiça e apresenta como ideias centrais o exilio e a errância, quer físicos, quer interiores - aparece de modo geral equiparado ao sujeito poético e ao povo português. Sujeito poético, povo português, figura mítica deixaram o seu espaço natural e as paisagens natais para longo tempo andarem errantes por diversas terras e povos e por fim regressarem à sua terra, a Ítaca que em Manuel Alegre, com muita frequência, aparece como a terra pátria e também como algo de ideal (a ilha que fica sempre mais a sul, a tão azul, como diz em Um Barco para Ítaca) que a insatisfação humana sempre busca sem jamais a encontrar, porque a Ítaca que se procura nunca é a aquela a que se chega.

$\mathrm{E}$, como Ulisses se identifica com o povo português, o sangue que corre da ferida simboliza o sangue e o sofrimento de Portugal. Um sofrimento equacionado em vários momentos da nossa história que marcaram o ser português. Um sofrimento que o fio da memória vai desdobando ao longo de Doze Naus. É sobre esse espaço Ítaca-Portugal que Ulisses-poeta pensa, desejando - é evidente - que nele reflectisse também o povo português. Essa é a preocupação do livro do princípio ao fim.

E, como ilustração dessa inquirição e insatisfação, permita-se-me apenas, a concluir, a citação e breve alusão ao poema "A curva" (p. 87), o último do livro, que é outro exemplo elucidativo de busca constante, de questionação permanente e nunca satisfeita. A curva é espaço abstracto e simbólico que nos separa do desconhecido, do incerto; a curva é o ponto ou sítio onde «alguém tem de aparecer», porque a «vida toda» é «sonho a esperar sempre / naquela curva não importa quem», mas alguém que «há-de aparecer» e que aponte um aquém ou um além, ou mesmo simplesmente e só «o horizonte / daquela curva onde se espera alguém». O poema é constituído por três quadras em rima cruzada $(A B A B)$, onde se insiste no indefinido "alguém", a cada passo em anáfora (início das estrofes $1 \mathrm{e}$ 3 , bem como a começar o verso 3 da estrofe 2), e onde as aliterações surgem em vários versos (s nos versos 4,5 , c ou q no 6 e a no 9). Transcrevo o poema:

Alguém tem de aparecer naquela curva mesmo que se não saiba o que é depois se estrada larga ou morte ou água turva se solidão ou um a ser já dois.

$A$ vida toda em sonho a esperar sempre naquela curva não importa quem alguém que diga o quê e saia ou entre ainda que depois não mais ninguém.

Alguém há-de aparecer alguém que aponte quem sabe se um aquém ou se um além ou nada mais senão o horizonte daquela curva onde se espera alguém. 
(Página deixada propositadamente em branco) 
(Página deixada propositadamente em branco) 


\section{Índice de palavras-chave}

(abrange vol. 1 e 2) 
(Página deixada propositadamente em branco) 


\section{A}

aemulatio 131

Afonso Africano 337

Afrodite 23

ágora 43

Agostinho 305 (Confissões) 305

alegoria 337

alimentação 147

Amadeu Lopes Sabino 467 (Vidas Apócrifas) 467

Américas 395

Anfiteatro Flaviano 199

Antiguidade Tardia 313

António Sérgio 459

Apuleio 265 (conto de Amor e Psique) 265 (O Burro de Ouro) 265

aristocracia romana 113

Aristófanes 49

arquitectutra romana 89

Artémis 23

Atenas 43

Avicena 89

B

Bárbaros 15, 313

Barroco 353

Beócia 459

Bernardo de Gordon 89 (De Ingenio Sanitatis) 89 (De Modo Medendi) 89

Bernardo Soares 451

biografia 223

botânica 97

branquitude 417

bucolismo 459

C

cave 35

Célio Rufo 121

César 215
Cícero 121 (Verrinas) 121

Cilícia 121

Cítia 459

colégios 369

comércio 43

Companhia de Jesus 395

Constantinopla 313

contra-reforma 353

coro 183

\section{D}

Della Porta 361

Diogo Pires 345

Dioniso 29

ditadura militar 459

Domiciano 207

E

Édipo 409

educação 369

Egéria 327 (Itinerarium) 327

(Peregrinatio) 327

Egipto 15

ensino 425, 439

epigrama 199

epistemologia 417

escrita feminina 353

espaço 337

espaço de exílio 451

espaço dramático 15

espaço fisico 59,83

espaço médico e social 83

espaço poético 155

espaço psicológico 59

espaço rural 49

espaços da morte 255

espaço urbano 169,199

Espanha 459

Ésquilo 15

Estácio 207 (Siluae) 207

Europa 313 
Eurípides 23

exploração das províncias 121

F

Feliciana Enríquez de Guzmán 377

Fílon de Bizâncio 73

filosofia 475

fisiognomonia 361

Fócida 459

fronteiras 313

G

Galeno 89

Germânia 215

Grã-Bretanha 247

Grécia Antiga 49

guerra 43

\section{H}

Héracles 29

herói 409

hexâmetros leoninos 97

Hipólito 23

História da África 425

História da Ciência 395

História dos Jesuítas 369

historiografia trágica 255

Horácio 131

hortus 231

hospital 89

humanidade 175

Humanismo 369

Humanismo Renascentista 345

humanização 175 iatromea 83

Idade Média 97

ilusão 59

imaginação 431

imaginário 169

Império Romano 223

insula 89, 231

J

jardim 377

jogos 199

Judeus séc. I 191

K

Kant 431

L

literatura 425

literatura latina 105

locus amoenus 377

Lucrécio 475

Luculo 113

lugares santos 327

luxúria 113

M

mar 23

Marcial 199, 345 (Liber de Spectaculis) 199

medica 83

medicina 97,361

melancolia 361

memória 305

metricologia 105

mineração 395

misticismo 353 
mito 409 (clássico) 377 (de Orfeu) 491

mitologia 169

Montpellier 89

mulher 35,377

$\mathbf{N}$

natureza 35,175

natureza selvagem 23

Neolatim 395

Neo-romantismo 409

Nero 223

Nietzsche 409

ninfa 35

ninfolepsia 65

\section{0}

obstetrix 83

Orcoménia 459

Orfeu da Conceição 491

Orfeu Negro 491

Ovídio 451

$\mathbf{P}$

paisagem 215, 475

paisagem bucólica 65

paisagens de Virgílio 139

palavra clássica 467

palavra contemporanea 467

panolepsia 65

património 73

pedagogia 439

periaktoi 183

personagens-esteio 183

Píndaro 131

pintura romana 191

plantas medicinais 97

Plauto 439 (Truculentus) 439

Plutarco 237 (Vidas Paralelas) 237,
467

poesia 169, 395, 475 (didáctica) 97

(lírica) 131

poesia épica portuguesa 337

poesia novilatina 345

poética da expressão 105

Pompeios 191

população 43

Portugal 459

Poséidon 23

público e privado 113

R

Ratio Studiorum 369

realidade 59

recepção 409

reinvenção 417

religião 431

Roma 147, 169, 191, 237, 313

roubo de obras de arte 121

Rússia 459

\section{S}

salazarismo 459

scaenae ductiles 183

Século de Augusto 169

Sete Maravilhas 73

Sicília 121

Sófocles 459

suburbanum 231

Suetónio 223, 231 (Vitae duodecim Caesarum) 231

super-homem 409

$T$

Tácito 215, 247, 255 (Agricola) 247

(Annales) 255

teatro 439

Tebas 29, 459 
tempo 305

Teócrito 459

teologia política 431

Tibério 255

tirania 255

tradução 131

tragédia 29, 409

tragédia grega 15, 417

tragédia romana 175

transgressão 377

trilogia 409

turismo 73

$\mathbf{U}$

unidade de acção, de tempo e de

espaço 183

V

valetudinaria 89

Verfremdung 183

Via Domiciana 207

viagem 15

villa 89, 113, 231

Virgílio 139, 147, 155, 491 (Bucólicas)

147, 155 (Geórgicas) 491 
(Página deixada propositadamente em branco) 
(Página deixada propositadamente em branco) 

OBRA PUBLICADA

COM A COORDENAÇÃO

CIENTÍFICA

Centro de Estudos

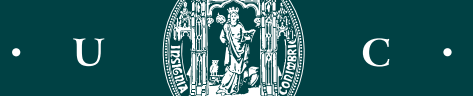

1

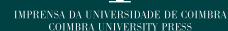

U 